\title{
Site U1424
}

R. Tada, R.W. Murray, C.A. Alvarez Zarikian, W.T. Anderson Jr., M.-A. Bassetti, B.J. Brace, S.C. Clemens, M.H. da Costa Gurgel, G.R. Dickens, A.G. Dunlea, S.J. Gallagher, L. Giosan, A.C.G. Henderson, A.E. Holbourn, K. Ikehara, T. Irino, T. Itaki, A. Karasuda, C.W. Kinsley, Y. Kubota, G.S. Lee, K.E. Lee, J. Lofi, C.I.C.D. Lopes, L.C. Peterson, M. Saavedra-Pellitero, T. Sagawa, R.K. Singh, S. Sugisaki, S. Toucanne, S. Wan, C. Xuan, H. Zheng, and M. Ziegler²

\section{Chapter contents}

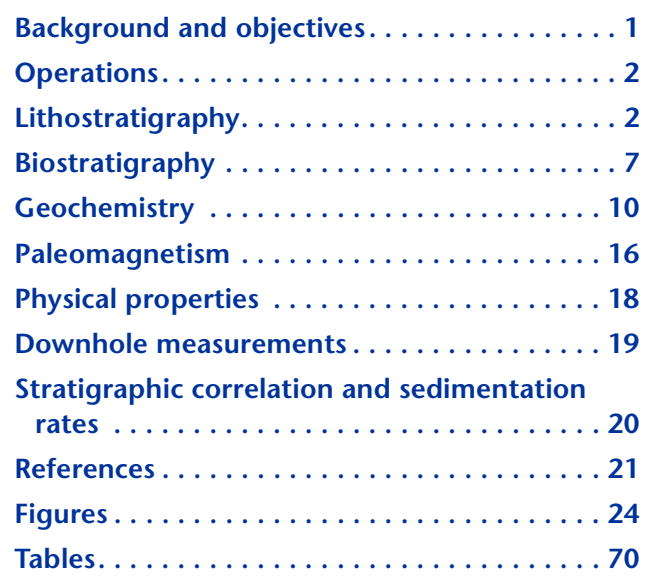

'Tada, R., Murray, R.W., Alvarez Zarikian, C.A., Anderson, W.T., Jr., Bassetti, M.-A., Brace, B.J., Clemens, S.C., da Costa Gurgel, M.H., Dickens, G.R., Dunlea, A.G., Gallagher, S.J., Giosan, L., Henderson, A.C.G., Holbourn, A.E., Ikehara, K., Irino, T., Itaki, T., Karasuda, A., Kinsley, C.W., Kubota, Y., Lee, G.S., Lee, K.E., Lofi, J., Lopes, C.I.C.D., Peterson, L.C., Saavedra-Pellitero, M., Sagawa, T., Singh, R.K., Sugisaki, S., Toucanne, S., Wan, S., Xuan, C., Zheng, H., and Ziegler, M., 2015. Site U1424. In Tada, R., Murray, R.W., Alvarez Zarikian, C.A., and the Expedition 346 Scientists, Proc. IODP, 346: College Station, TX (Integrated Ocean Drilling Program). doi:10.2204/iodp.proc.346.105.2015

'Expedition 346 Scientists' addresses.

\section{Background and objectives}

Integrated Ocean Drilling Program (IODP) Site U1424 is in the eastern part of the marginal sea surrounded by the Japanese Islands, the Korean Peninsula, and the Eurasian continent at $40^{\circ} 11.40^{\prime} \mathrm{N}, 138^{\circ} 13.90^{\prime} \mathrm{E}$ and 2808 meters below sea level. The site is at the same location as Ocean Drilling Program (ODP) Site 794 and is $\sim 200 \mathrm{~km}$ southwest of the entrance of the Tsugaru Strait (Fig. F1). Site U1424 is near the boundary between the Japan and Yamato Basins and $\sim 10 \mathrm{~km}$ west of the submarine Toyama Channel that extends from the central part of Honshu Island. The site is mainly under the influence of the second branch of the Tsushima Warm Current and close to the present position where the third branch merges with the second branch of the Tsushima Warm Current during the present summer. Previous drilling at Site 794 revealed that the site is characterized by very slow $(\sim 30$ $\mathrm{m} / \mathrm{m}$.y.) yet continuous sedimentation during the last 4 m.y. (Tada, 1994), which is ideal to detect the contribution of eolian dust from the Asian continent. Preliminary examination of the Pleistocene sediment suggests possible occurrence of ice-rafted debris (IRD), suggesting its potential utility for the study of IRD.

Site U1424 is the southernmost site of the northern half of the latitudinal transect targeted by IODP Expedition 346 and is also the second deepest site of the depth transect. The location of Site U1424 was selected specifically to identify the southern limit of IRD events. Together with the results from IODP Sites U1422 and U1423, identification of IRD events at this site and correlation with previous sites will allow us to reconstruct temporal changes in the southern limit of sea ice in the marginal sea during the last 4 m.y.

Site U1424 is also ideal for reconstruction of eolian dust flux, grain size, and provenance changes since $\sim 4 \mathrm{Ma}$, considering the very low sedimentation rate observed at Site 794. Although IRD may contribute to the total terrigenous flux in several intervals, the grain size range of eolian dust (4-32 $\mu \mathrm{m})$ may allow differentiation of the eolian dust component from other terrigenous components.

This site is also useful to reconstruct changes in deepwater oxygenation and calcium carbonate compensation depth during the last 4 m.y., particularly because Site U1424 is the second deepest site drilled during Expedition 346. At the deepest site previously drilled during this expedition, Site U1422, this objective was neg- 
atively impacted by the presence of numerous turbidites in the interval older than $2.5 \mathrm{Ma}$.

\section{Operations}

Three holes were drilled at Site U1424 (proposed Site JB-1) (Table T1; see also Fig. F2 in the "Expedition 346 summary" chapter [Tada et al., 2015a]). Hole U1424A was cored using the advanced piston corer (APC) to $158.8 \mathrm{~m}$ core depth below seafloor (CSF-A) (see the "Methods" chapter [Tada et al., 2015b]). Similarly, Hole U1424B was cored with the APC to 154.7 m CSF-A, and Hole U1424C was cored to only $63.9 \mathrm{~m}$ CSF-A. A total of 41 cores obtained $380.68 \mathrm{~m}$ of sediment (101\% recovery).

\section{Transit from Site U1423}

The transit to Site U1424 was very short. The 98.5 $\mathrm{nmi}$ distance was covered in $10 \mathrm{~h}$ at an average speed of $9.9 \mathrm{kt}$. The sea passage ended at $0738 \mathrm{~h}$ on $25 \mathrm{Au}-$ gust 2013. The vessel was maneuvered over the location coordinates and turned over to dynamic positioning control. By $0815 \mathrm{~h}$ the vessel was stabilized for rig floor operations to begin at Site U1424.

\section{Hole U1424A}

The drill string was tripped to the seafloor, and the bit was positioned at 2806 meters below rig floor (mbrf) for the mudline core. However, this core barrel was recovered empty. The bit was repositioned at 2816 mbrf for the second attempt, and Hole U1424A was spudded at $1525 \mathrm{~h}$ on 25 August 2013. Based upon recovery from the first core, a seafloor depth of 2818.7 mbrf was established. APC coring continued with 17 cores recovered to $158.8 \mathrm{~m}$ CSF-A. With the top drive left in place, the drill string was pulled clear of the seafloor at $0645 \mathrm{~h}$ on 22 August, ending Hole U1424A. Coring recovered $161 \mathrm{~m}$ of sediment (101\%). One temperature measurement was taken using the advanced piston corer temperature tool (APCT-3) temperature shoe on Core 346-U1423A-4H at $35.3 \mathrm{~m}$ CSF-A. This measurement fell exactly on the temperature gradient established during Leg 127 when this site was first cored (Site 794). Therefore, no additional temperature measurements were made at this site.

\section{Hole U1424B}

The ship was offset $15 \mathrm{~m}$ north of Hole U1424A, and Hole U1424B was started at $0740 \mathrm{~h}$ on 26 August 2013. Recovery from Core 346-U1423B-1H established a seafloor depth of 2819.8 mbrf. APC coring continued uneventfully with 17 cores recovered to 154.7 m CSF-A. The bit cleared the seafloor at $2035 \mathrm{~h}$ on 26 August, ending Hole U1424B. Coring recovered $155.3 \mathrm{~m}$ of sediment $(100 \%)$.

\section{Hole U1424C}

The ship was offset $15 \mathrm{~m}$ south of Hole U1424A, and Hole U1424C was spudded at 2125 h on 26 August 2013. The operations plan for this hole was amended to conserve valuable operating time. Cores 346U1424C-1H through $3 \mathrm{H}$ were taken for postexpedition optically stimulated luminescence (OSL) dating, and Cores $4 \mathrm{H}$ through $6 \mathrm{H}$ were taken for high-resolution geochemical analyses. Hole U1424C was started with the bit positioned at the same depth as it was for Hole U1424A (2416 mbrf). APC coring extended from the seafloor to $63.9 \mathrm{~m}$ CSF-A.

OSL sampling involved special core handling procedures, and Hole U1424C was intentionally planned to be cored during the night to minimize core exposure to light. Cores $1 \mathrm{H}$ through $3 \mathrm{H}$ were cut in sequence into $1.5 \mathrm{~m}$ whole-round sections directly on the drill floor sequentially as the core was pulled out of the core barrel and placed into opaque aluminumlined pouches, labeled, sealed, and stored in refrigerated core storage. The drill string was pulled out of the hole, clearing the seafloor at $0320 \mathrm{~h}$ on $27 \mathrm{Au}-$ gust, and was back on the rig floor at $0815 \mathrm{~h}$ on 27 August. The rig floor was secured for transit, thrusters were raised, and the sea passage to IODP Site U1425 began at $0854 \mathrm{~h}$ on 27 August.

\section{Lithostratigraphy}

Drilling at IODP Site U1424 penetrated to a maximum subbottom depth of $158.8 \mathrm{~m}$ in Hole U1424A, recovering a total of $161 \mathrm{~m}$ of sediment for a recovery rate of $101 \%$. The shipboard lithostratigraphic program involved detailed visual assessment of sediment composition, color, sedimentary structures, and bioturbation intensity, supplemented by petrographic analysis of smear slides (64 from Hole U1424A, 48 from Hole U1424B, and 7 from Hole $\mathrm{U} 1424 \mathrm{C}$ ) and bulk mineralogic analysis by X-ray diffraction (XRD) (22 samples). These objective criteria were used to describe the sediment succession, to define facies and facies associations, and to divide the stratigraphic section into major lithologic units.

The sedimentary succession recovered at Site U1424 extends from the Pliocene to Holocene and is dominated by clay and diatom ooze. Volcaniclastic material represents a minor component throughout the sediment succession, except where concentrated in tephra (i.e., volcanic ash) layers.

The recovered sediment is divided into two major lithologic units (I and II, following Tada [1994]) 
based on sediment composition, especially the biosiliceous fraction content. Units I and II are each further divided into two subunits. The character of the sedimentary physical properties, including natural gamma radiation (NGR), magnetic susceptibility, color reflectance parameters, and density, reflects the distribution of the various sediment components and lithologies (see "Physical properties"). The major characteristics of the sedimentary sequence at Site U1424, together with some of these additional properties, are summarized in Figures F2, F3, and F4, whereas the between-hole correlation of sedimentary units is shown in Figure F5. Note that for Hole U1424C, the top three cores were immediately sealed upon recovery for OSL dating and hence not described.

\section{Unit I}

Intervals: $346-\mathrm{U} 1424 \mathrm{~A}-1 \mathrm{H}-1,0 \mathrm{~cm}$, to $8 \mathrm{H}-1,0 \mathrm{~cm}$; $346-\mathrm{U} 1424 \mathrm{~B}-1 \mathrm{H}-1,0 \mathrm{~cm}$, to $8 \mathrm{H}-3,125 \mathrm{~cm} ; 346-$ U1424C-4H-1, $0 \mathrm{~cm}$, to $7 \mathrm{H}-\mathrm{CC}, 22 \mathrm{~cm}$

Depths: Hole U1424A = 0- 64 m CSF-A; Hole $\mathrm{U} 1424 \mathrm{~B}=0-63.95 \mathrm{~m}$ CSF-A; Hole U1424C = 25.90-64.02 m CSF-A

Age: Holocene to early Pleistocene (2.1 Ma)

\section{Lithologies and structures}

Unit I consists of Holocene to early Pleistocene clay with small amounts of diatom-bearing, diatom-rich, foraminifer-bearing clay and rare (nonbiogenic) calcareous layers (Figs. F2, F3, F4). Pyrite and volcaniclastic materials represent a minor component throughout the sediment succession. Numerous discrete millimeter- to centimeter-thick tephra layers (vitric and scoria) are described throughout Unit I (total of 132 tephra beds, including 72 tephra beds $>0.5 \mathrm{~cm}$ thick; Fig. F6).

The most distinguishing sedimentary feature of Unit I sediment is the alternating decimeter-scale colorbanded bedding, which characterizes much of the sequence, with dark, organic-rich clay intervals interspersed with lighter colored, organic-poor intervals. The relative frequency of these color alternations as well as the intensity of bioturbation are used as criteria to divide Unit I into Subunits IA and IB.

\section{Bulk mineralogy}

The XRD analysis results are listed in Table T2. In general, Unit I sediment at Site U1424 is composed mainly of quartz, plagioclase, and clay minerals (including smectite, illite, and kaolinite and/or chlorite), as well as biogenic opal-A and minor amounts of halite and pyrite. Calcite was not detected in the measured samples but is sparsely present (foramin- ifers and nannofossils) in some layers within the upper $28 \mathrm{~m}$ of Unit I, as observed in smear slides.

Figure F7 shows the downcore variations in peak intensity of the identified minerals at Site U1424. In general, quartz, plagioclase, smectite, illite, kaolinite and/or chlorite, and K-feldspar contents show a long-term trend toward increasing counts. Peak heights of these minerals tend to be higher in Unit I and lower in Unit II, which is similar to observations at the other two Japan Basin sites (Sites U1422 and U1423). Peak heights of opal-A are generally much lower in Unit I and higher in Unit II. The peak intensity of pyrite at $20.56 \mathrm{~m}$ CSF-A in Hole U1424A is very high. Halite is always present in samples with a higher intensity in Unit II and lower intensity in Unit I.

\section{Subunit IA}

Intervals: $346-\mathrm{U} 1424 \mathrm{~A}-1 \mathrm{H}-1,0 \mathrm{~cm}$, to $5 \mathrm{H}-6,114$ $\mathrm{cm}$; 346-U1424B-1H-1, $0 \mathrm{~cm}$, to $6 \mathrm{H}-2,133 \mathrm{~cm}$; $346-\mathrm{U} 1424 \mathrm{C}-4 \mathrm{H}-1,0 \mathrm{~cm}$, to $5 \mathrm{H}-7,30 \mathrm{~cm}$

Depths: Hole U1424A $=0-42.94 \mathrm{~m}$ CSF-A; Hole $\mathrm{U} 1424 \mathrm{~B}=0-43.40 \mathrm{~m}$ CSF-A; Hole U1424C = 25.90-44.45 m CSF-A

Age: Holocene to early Pleistocene (1.2 Ma)

\section{Lithology and structures}

Subunit IA consists dominantly of clay with subordinate amounts of diatomaceous (i.e., diatom bearing and diatom rich) and foraminifer-bearing clay. Tephra layers intercalated in the clay sequence are a minor but common component of Subunit IA.

Subunit IA is characterized by decimeter-scale alternations of light and dark colored sediment intervals (Fig. F8), which show up clearly in the $L^{*}, a^{*}$, and $b^{*}$ records (see "Physical properties"). The light colored intervals are mainly composed of light greenish gray clay with some diatoms. Within these intervals, millimeter- to centimeter-scale layers of gray, dark greenish gray, and very dark gray clays are observed. The light intervals are slightly bioturbated, although not enough to disrupt preservation of the thin, darker banding. Some prominent millimeter- to centimeter-scale olive-gray layers are also described throughout the light intervals. Detailed examination of these layers reveals that they are composed of clay minerals. Some of them show abundant amounts of pyrite (sometimes visible to the naked eye).

The contrasting dark layers that dominate Subunit IA correspond to dark grayish brown organic-rich clay intervals with some foraminifers and pyrite throughout. Although some of these intervals show evidence of slight disturbance from burrowing, the dark layers are mostly finely laminated with no ap- 
parent bioturbation. Foraminifers (mostly planktonic) are generally restricted to millimeter-scale (foraminifer-bearing) yellowish layers (Fig. F9). These yellowish layers are not necessarily present in all dark intervals. The lower contacts of the dark layers within Subunit IA are mostly sharp (i.e., not bioturbated), whereas the upper contact with the light greenish gray intervals usually appears gradual because of bioturbation (at the time of deposition of the overlying light greenish gray clay). Most of the dark brown intervals are underlain by centimeterscale gray clay (e.g., Sections 346-U1424B-2H-3, 2H6 , and 3H-3; Fig. F10). This gray clay is slightly bioturbated but only with the underlying light greenish gray clay (i.e., not with the overlying dark brown interval). As a result, these gray clay layers do not result from the mixing of the dark brown and greenish gray intervals but constitute an additional facies. These deposits probably reflect transitional depositional conditions between those prevailing during deposition of the organic-poor, light greenish gray and the organic-rich, dark brown intervals.

Tephra layers in Subunit IA are mostly centimeterthick deposits interbedded within the light greenish gray and dark brown/grayish brown clay intervals. The number of tephra layers per core with a thickness $>0.5 \mathrm{~cm}$ is highest in Subunit IA (Fig. F6; Table T3). Tephra are mostly white and light gray in color (i.e., vitric) but some very dark to black tephra (i.e., scoriaceous) are also described. We tested the potential of using the $\mathrm{L}^{*}$ data from the color spectrophotometer as an indicator for tephra occurrence in Hole U1424B. When only $L^{*}$ values $\geq 44$ are considered (i.e., the brightest sediment layers), a good match is found between the number of tephra layers and the $\mathrm{L}^{*}$ data (Fig. F6). The highest peaks in $\mathrm{L}^{*}$ occur at $\sim 40$ m CSF-A, consistent with a high cumulative tephra thickness and the largest number of individual thick tephra layers. Between $~ 90$ and 130 m CSF-A, only a few high $\mathrm{L}^{*}$ values $\geq 44$ occur. This is also consistent with the relatively small number of tephra layers in this interval. The results of this simple test suggest that high $L^{*}$ values can be used as a guide to identifying tephra layers at this site and potentially others. This technique works well for Site U1424 because the major lithologies are carbonate poor and greenish to brownish colors dominate. Thus, highly reflective layers like whitish tephra layers stand out from the darker background color and can be identified by measured $\mathrm{L}^{*}$ profiles. Core $346-\mathrm{U} 1424 \mathrm{~B}-7 \mathrm{H}$ is an exception because it contains an interval with pale yellow color that is rich in carbonate content. Black or dark colored scoriacious tephra layers with low $\mathrm{L}^{*}$ values would not be detected by this method.

\section{Composition}

The principal lithologic components of lithologies in Subunit IA are terrigenous, volcanic, and biogenic (see Site U1424 smear slides in "Core descriptions"). The terrigenous components in this subunit are dominated by clay and fine silty clay fractions. In Subunit IA, the light greenish gray intervals are mostly composed of siliciclastic fine-grained material (up to $80 \%$ ) dominated by clay minerals. Small pyrite framboids are distributed mainly in the dark layers. Discrete accumulations of well-developed pyrite crystals are observed at the sediment surface as well as in the smear slides (Sample 346-U1424C-4H$3,78 \mathrm{~cm}$; Fig. F11).

Volcanic glass and pumice account for nearly $100 \%$ of the tephra layers, even though sometimes the volcanic material appears to be mixed with a siliciclastic component. Diatoms and siliceous sponge spicules dominate the biogenic fraction with some radiolarian-enriched levels. Calcareous nannofossils and foraminifers (mostly planktonic) can be abundant (up to $30 \%$ ) in the dark brown layers (and in the yellowish laminae in particular). A significant biogenic component is found at levels in the light greenish sediment, made of planktonic foraminifers mixed to high abundance $(\sim 60 \%)$ of microcrystalline calcite (micrite).

\section{Subunit IB}

Intervals: $346-\mathrm{U} 1424 \mathrm{~A}-5 \mathrm{H}-6,114 \mathrm{~cm}$, to $8 \mathrm{H}-1,0$ $\mathrm{cm} ; 346-\mathrm{U} 1424 \mathrm{~B}-6 \mathrm{H}-2,133 \mathrm{~cm}$, to $8 \mathrm{H}-3,125$ $\mathrm{cm} ; 346-\mathrm{U} 1424 \mathrm{C}-5 \mathrm{H}-7,30 \mathrm{~cm}$, to $7 \mathrm{H}-\mathrm{CC}, 22 \mathrm{~cm}$

Depths: Hole U1424A = 42.94- 64 m CSF-A; Hole $\mathrm{U} 1424 \mathrm{~B}=43.40-63.95 \mathrm{~m}$ CSF-A; Hole U1424C = 44.45-64.02 m CSF-A

Age: early Pleistocene (1.2-2.1 Ma)

\section{Lithology and structures}

Subunit IB is transitional downward from Subunit IA and is identified by a decrease in the frequency of dark and light color alternation and the dominance of light greenish gray and light gray clay (Fig. F12). Subunit IB consists dominantly of clay with subordinate amounts of diatomaceous clay. Some millimeter- to centimeter-scale layers of gray, dark greenish gray, very dark gray, and olive-gray clay (previously described in Subunit IA) are observed. Olive-gray clay intervals are particularly well expressed in Core 346-U1424A-7H. Contrary to Subunit IA, some distinct centimeter-scale layers of pale yellow carbonate-rich (calcite) sediment are described in Subunit IB (Sections 346-U1424A-6H-1, 6H-3, and 6H-4). Bioturbation increases gradually with depth, and sedi- 
ment mottling and disruption of laminae and color banding is more prevalent.

Tephra layers intercalated in the clay sequence are a minor but common component of Subunit IB. As described in Subunit IA, tephra layers are mostly centimeter-scale light (vitric) deposits. A $4 \mathrm{~cm}$ thick dark tephra (scoria) is observed in Subunit IB (e.g., interval 346-U1424B-7H-6, $118-122 \mathrm{~cm}$ ). Some of the (light) tephra layers described within the light greenish gray intervals show distinct millimeter-scale gray and grayish green laminations or cross laminations. The latter are interpreted as tephra layers that have been remobilized and emplaced as turbidite deposits (e.g., Section 346-U1424A-6H-5; Fig. F13).

\section{Composition}

The principal components of the lithologies in Subunit IB are terrigenous, volcanic, and biogenic in origin (see Site U1424 smear slides in "Core descriptions"). The major difference between the lithologies of Subunits IA and IB is the reduced occurrence of calcareous microfossils and slightly higher contents of the biosiliceous fraction.

Terrigenous materials compose the bulk (>80\%) of Unit I sediment, which is dominated by clay. Clay minerals are found to be abundant, whereas the lithics are generally rare. Very light gray clay beds are frequent in Subunit IB and made of microcrystalline calcite (from 50\% to 100\%).

Volcanic glass usually occurs as a minor dispersed component $(\sim 5 \%)$ throughout the sections. A very fine grained tephra layer (clay size) is observed in Sample 346-U1424A-6H-6, $102 \mathrm{~cm}$.

The biogenic fraction is generally low $(<10 \%)$ in Subunit IB and is dominated by diatoms and sponge spicules, with few calcareous microfossils.

\section{Unit II}

Intervals: $346-\mathrm{U} 1424 \mathrm{~A}-8 \mathrm{H}-1,0-100 \mathrm{~cm}$, to $17 \mathrm{H}-$ CC, $13 \mathrm{~cm}$; 346-U1424B-8H-3, $125 \mathrm{~cm}$, to $17 \mathrm{H}-$ CC, $18 \mathrm{~cm}$

Depths: Hole U1424A = 64-158.87 m CSF-A; Hole $\mathrm{U} 1424 \mathrm{~B}=63.95-155.08 \mathrm{~m}$ CSF-A

Age: early Pleistocene $(2.1 \mathrm{Ma})$ to Pliocene $(<4.7$ Ma)

\section{Lithology and structures}

Unit II consists of early Pleistocene to Pliocene clay, diatomaceous clay, and diatom ooze (Figs. F2, F3, F4). Pyrite and volcaniclastic materials represent minor components throughout the succession. Discrete millimeter- to centimeter-scale tephra layers (vitric) are found throughout Unit II (89 tephra beds, including 30 tephra beds $>0.5 \mathrm{~cm}$ thick). Some peaks in tephra thickness in Unit II indicate that rare but thick tephra deposition occurred during the deposition period of Unit II (Fig. F6).

Unit II is distinguished from Unit I on the basis of the sediment color and a significant increase in diatom content relative to terrigenous sediment from top to bottom. This lithologic change is supported by NGR measurements, which show lower values in Unit II than in Unit I that are likely related to the increasing/decreasing content of the diatomaceous/terrigeneous fraction downhole in the sedimentary sequence. Sediment of Unit II is moderately to heavily bioturbated and is often mottled. The degree of bioturbation changes vertically. A few turbidite deposits are observed throughout Unit II. The diatom content and the intensity of bioturbation are the criteria used to further divide Unit II into Subunits IIA and IIB.

\section{Bulk mineralogy}

The results of XRD analyses conducted on Hole U1424A sediment are listed in Table T2. In general, the bulk mineral composition of Unit II sediment is similar to that of Unit I. The major difference is the higher opal-A peak height, the higher peak intensity of halite, and the occurrence of dolomite in some concretions in Unit II. Figure F14 shows the image of one section (346-U1424A-13H-5A) with a representative concretion (dolomite). The sediment scratched from the surface of the concretion consists of very fine $(\sim 2-4 \mu \mathrm{m})$ dolomite grains (see Fig. F15 observed by smear slide), which was confirmed by XRD (Fig. F16). This dolomite may suggest that biogenic nannofossils and/or foraminifers have been affected by diagenesis (dolomization), at least in this horizon.

\section{Subunit IIA}

Intervals: $346-\mathrm{U} 1424 \mathrm{~A}-8 \mathrm{H}-1,0-100 \mathrm{~cm}$, to $9 \mathrm{H}-4$, $141 \mathrm{~cm} ; 346-\mathrm{U} 1424 \mathrm{~B}-8 \mathrm{H}-3,125 \mathrm{~cm}$, to $9 \mathrm{H}-7,50$ $\mathrm{cm}$

Depths: Hole U1424A $=\sim 64-79.21 \mathrm{~m}$ CSF-A; Hole $\mathrm{U} 1424 \mathrm{~B}=63.95-78.66 \mathrm{~m}$ CSF-A

Age: early Pleistocene (2.1 Ma) to late Pliocene (2.7 Ma)

\section{Lithology and structures}

Subunit IIA consists dominantly of brownish and greenish diatom-bearing and diatom-rich clay, as well as clay with a few turbidite beds (Figs. F13, F17). This subunit is considered transitional to the underlying Subunit IIB, which is defined by the consistent appearance of diatom ooze in the section.

Subunit IIA sediment is heavily bioturbated. This bioturbation leads to poor preservation of the original sedimentary structures, which inhibits their rec- 
ognition (e.g., color banding, laminae, etc.), with the exception of some fine-grained turbidite deposits within the diatom-bearing and diatom-rich clays (e.g., Sections 346-U1424B-8H-4 and 8H-7). Each turbidite bed is a few centimeters thick. The turbidite deposits show homogeneous centimeter-scale olivegray clay intervals overlying millimeter- to centimeter-scale silty to sandy beds composed mainly of volcaniclastic particles. The latter intervals show sharp erosional basal contacts, and parallel and/or cross lamination are observed (Fig. F13).

Tephra layers, intercalated in the diatom-bearing clay and clay sequence, are a minor but common component of Subunit IIA.

\section{Composition}

Subunit IIA is dominated by fine-grained material, mostly clay minerals (see Site U1424 smear slides in "Core descriptions"). Biosiliceous components (diatoms, siliceous sponge debris, radiolarians, and silicoflagellates) are present but occur in low abundances (5\%-10\%).

\section{Subunit IIB}

Intervals: $346-\mathrm{U} 1424 \mathrm{~A}-9 \mathrm{H}-4,141 \mathrm{~cm}$, to $17 \mathrm{H}-\mathrm{CC}$, $13 \mathrm{~cm}$; 346-U1424B-9H-7, $50 \mathrm{~cm}$, to 17H-CC, 18 $\mathrm{cm}$

Depths: Hole U1424A = 79.21-158.87 m CSF-A; Hole U1424B = 78.66-155.08 m CSF-A

Age: late-early Pliocene ( $>2.7 \mathrm{Ma})$

\section{Lithology and structures}

Subunit IIB consists dominantly of brownish and greenish diatom-bearing clay and diatom ooze, with a few clay intervals corresponding to fine-grained turbidite beds (in the upper part of the subunit in particular, see Section 346-U1424A-9H-5; Figs. F13, F18). The abundance of diatoms and other siliceous components is key in the recognition of Subunit IIB, which typically comprises $>70 \%$ of the sediment based on smear slides. A significant decrease in NGR values from Subunit IIA to Subunit IIB coincides with the increasing diatom content of Subunit IIB sediment. Bioturbation is moderate to heavy and distinctive mottling is displayed in some sections (Fig. F18).

Tephra layers (vitric and scoriaceous) intercalated in the diatom-bearing clay and diatom ooze are a minor but common component of Subunit IIB. The thickest tephra layer, with a maximum thickness of $15 \mathrm{~cm}$, occurs in the lower part of Subunit IIB (interval 346-U1424A-13H-6, 143-158 cm; 120.06-120.21 $\mathrm{m}$ CSF-A). Most of the layers, however, had a thickness of $<1 \mathrm{~cm}$. A characteristic tephra containing "bubble-junction" type glass shards was found at 138.37-138.46 m CSF-A (interval 346-U1424A-15H$6,57-66 \mathrm{~cm}$ ). This distinctive type of glass shard is known for the Znp-Ohta tephra in Pliocene sequences in central Japan. Thus, there is a possibility that this marine tephra can be correlated to the ZnpOhta tephra. This tentative correlation will be tested by shore-based petrographic and geochemical analyses.

A large and abrupt NGR offset is observed near the base of the stratigraphic succession, at $138.08 \mathrm{~m}$ CSF-A in Hole U1424A (Sample 346-U1424A-15H-6, 28 $\mathrm{cm}$ ) and at 133.24 m CSF-A in Hole U1424B (Sample 346-U1424B-15H-5, $102 \mathrm{~cm}$ ). The NGR offset corresponds to a centimeter-scale tephra layer that represents a significant boundary between dark gray bioturbated sediment (above) and brown sediment (below). This unusually rapid change in color and the associated NGR offset could potentially reflect a discontinuity in the sediment record (genetically related to the tephra layer?).

\section{Composition}

The major lithologies in Subunit IIB are dominated by biosiliceous components $(>70 \%$ from Section 346-U1424A-9H-4 downhole [i.e., the Subunit IIAIIB transition]) (see Site U1424 smear slides in "Core descriptions"). Diatoms and siliceous sponge spicules are dominant in the biosiliceous fraction, whereas radiolarians and silicoflagellates are found only in rare or trace amounts $(1 \%-5 \%)$. These siliceous fossil assemblages characterize both the brownish and greenish color sediment in the "diatom ooze" category. Scattered glauconite crystals are occasionally observed in the diatom ooze (Fig. F19).

\section{Summary and discussion}

The sedimentary succession at Site U1424 records a history of terrigenous sedimentation since the Pliocene $(\sim 4.7 \mathrm{Ma})$, with the sequence showing an uphole decrease of the biosiliceous fraction (diatoms in particular) throughout the stratigraphic succession. The sedimentation at Site U1424 is largely dominated by hemipelagic and pelagic processes (Figs. F8, F12, F17, F18), although sedimentologic evidence also indicates occasional downslope (i.e., turbiditic) (Fig. F13) and volcanic processes.

The deposition of Unit II spanned the Pliocene through early Pleistocene. Unit II sediment is mainly composed of moderate to heavily bioturbated clays and diatom ooze (Fig. F17, F18). This composition reveals the predominance of both pelagic and hemipelagic sedimentation at Site U1424 during the Pliocene-early Pleistocene period, whereas the high content of diatoms (in Subunit IIB in particular) suggests 
high biological productivity at that time. Active circulation and oxygenation of the bottom water likely prevailed, as indicated by the high intensity of bioturbation.

Bioturbation at Site U1424 reaches a maximum in the upper part of Unit II (i.e., Subunit IIA; Fig. F17; late Pliocene-early Pleistocene), accompanying a significant decrease in diatom content relative to terrigenous sediment. The latter indicates a significant change in environmental conditions at Site U1424 during the late Pliocene-early Pleistocene. Bioturbation inhibits the recognition of former sedimentary structures (e.g., color banding, laminae, etc.) and associated sedimentary processes in Subunit IIA. However, some fine-grained turbidite deposits are described within the heavily bioturbated diatombearing and diatom-rich clay (Fig. F13), suggesting an increase in downslope processes at Site U1424 in the late Pliocene-early Pleistocene. Site U1424 is located west of the Sado Ridge, and as observed for Site U1422, the onset of turbidite deposition at that time is potentially related to the initiation of subduction in the region during the early Pleistocene (Tamaki et al., 1992). In such a case, the turbidite deposition may reflect sediment destabilization linked to tectonic movements (e.g., earthquakes) along the Sado Ridge. Nonetheless, these sediments represent a minor component in the sedimentary succession.

Sedimentation at Site U1424 greatly changed in the early Pleistocene, with the deposition of slightly bioturbated light greenish gray and light gray clay (Subunit IB; Fig. F12) followed by the progressive appearance of the dark brown organic-rich (laminated) layers during the Middle and Late Pleistocene (Subunit IA; Fig. F8). This pattern parallels previous observations from Site 794, as well as from Sites U1422 (Figs. F7, F10 both in the "Site U1422" chapter [Tada et al., 2015c]) and U1423 (Figs. F8, F10 both in the "Site U1423" chapter [Tada et al., 2015d]). For the last glacial cycle, the centimeter- to decimeter-scale alternations in sediment color reflect millennialscale variations associated with Dansgaard-Oeschger cycles, with each dark layer appearing to correspond to an interstadial (Tada et al., 1999). Detailed examination of the sediment immediately below the dark brown layers typically reveals a centimeter-scale gray clay interval that shows evidence of slight bioturbation and upward mixing of the light greenish gray clay that forms the light colored end member of the alternating light-dark color pairs (Fig. F10). This probably indicates transitional depositional conditions between deposition of the organic-poor, light greenish gray intervals (inferred oxic conditions; Tada et al., 1999) and the organic-rich, dark brown intervals deposited during suboxic to fully euxinic conditions (Tada et al., 1999). Further shore-based research will test this hypothesis.

Overall, the changes in sedimentation observed at Site U1424 since the Pliocene reflect the combined effects of climate oscillations, eustatic sea level changes, and local tectonism in the sea (Tada, 1994). Site U1424 also records the volcanic history of the Japanese Islands and the East Asian continent as shown by the numerous tephra layers found throughout the sedimentary succession (Fig. F6). These environmental changes are recorded in Holes U1424A-U1424C (Fig. F5), and further shore-based research will help decipher the role of climate, sea level, and tectonic changes on sedimentation at Site U1424.

\section{Biostratigraphy}

In Hole U1424A, a 159 m thick succession of Pliocene to Holocene sediment was recovered. Calcareous nannofossils are intermittent between 5 and 30 $\mathrm{m}$ CSF-A. Planktonic foraminifers are rare to absent with moderate to poor preservation below $40 \mathrm{~m}$ CSF-A, yet are mainly common to abundant in core catcher samples and thin calcareous layers shallower than 40 $\mathrm{m}$ CSF-A. Benthic foraminifers are absent shallower than $33 \mathrm{~m}$ CSF-A and are occasionally present below this depth. They show generally poor preservation. The overall assemblage composition indicates lower bathyal to abyssal paleodepths. Ostracods are extremely rare. The rare occurrence of calcareous microfossils probably reflects dissolution at the seafloor. The rare occurrence of agglutinated benthic foraminifers is probably due to unfavorable dysoxic conditions at the sediment/water interface. The radiolarian assemblages show good preservation except in the interval between 54 and $64 \mathrm{~m}$ CSF-A. Radiolarian biostratigraphic zonation ranges from the Larcopyle pylomaticus Zone (Pliocene) to the Botryostrobus aquilonaris Zone (Late Pleistocene). Diatom preservation is good throughout the succession. Overall, diatom abundance is low in most of the upper part of the succession and increases in the lower part of the succession. The diatom stratigraphy spans the interval from Zone NPD 12 (Pliocene) to NPD 7 (Late Pleistocene). Freshwater diatom species and opal phytoliths (land plant silica concretions), which might be related to freshwater input and/or wind transportation, are found sporadically. The radiolarian and diatom datums generally agree, with only some minor inconsistencies. The integrated calcareous and siliceous microfossil biozonation is shown in Figure F20, with microfossil datums shown in Table T4. An age-depth plot including biostratigraphic and paleomagnetic datums is shown in Figure F21. 
See "Stratigraphic correlation and sedimentation rates" for a discussion on sedimentation rates at Site U1424.

\section{Calcareous nannofossils}

Calcareous nannofossil biostratigraphy is based on analysis of core catcher and split-core section samples from Holes U1424A and U1424B. Only 9 of the 41 samples studied from Site U1424 contain nannofossils (Table T5).

Nannofossils are discontinuously present in Pleistocene sediment from 4.92 to 28.93 m CSF-A in Hole U1424A (Table T5). All samples below 32.26 m CSF-A in Hole U1424A and all core catcher samples from Hole U1424B lack nannofossils (Fig. F22). The calcareous nannofossil biostratigraphy is similar to the findings of Rahman (1992) at Site 794 (ODP Leg 127), of which Site U1424 was a redrill.

Nannofossil diversity at Site U1424 is low, and the assemblage is almost exclusively composed of Noelaerhabdaceae species belonging to the genera Gephyrocapsa and Reticulofenestra. The nannofossil assemblage consists of nine taxa, including Coccolithus pelagicus, Gephyrocapsa caribbeanica, Gephyrocapsa muellerae, Gephyrocapsa oceanica, Gephyrocapsa spp. ( $>4 \mu \mathrm{m})$, Gephyrocapsa spp. $(<4 \mu \mathrm{m})$, Reticulofenestra minuta, Reticulofenestra minutula, and Syracosphaera spp. Preservation is generally moderate, although it becomes good in Sample 346-U1424A-2H-7, $53 \mathrm{~cm}$ (16.05 m CSF-A), which is dominated by small Gephyrocapsa $(<4 \mu \mathrm{m})$ nannofossils.

Only one nannofossil subzone is recognized (Fig. F20) in Hole U1424A. Nannofossil Zones CN14b/ NN20 are recognized based on the absence of Emiliania huxleyi and Pseudoemiliania lacunosa and the presence of both G. caribbeanica and G. oceanica. The pervasiveness of barren samples below $32.26 \mathrm{~m}$ CSF-A does not allow the base of these zones to be identified.

\section{Radiolarians}

A total of 17 core catcher samples from Hole U1424A were prepared for radiolarian analyses. Radiolarians are generally common to abundant in the sequence, although they are rare between 54.3 and $64.0 \mathrm{~m}$ CSF-A (Samples 346-U1424A-6H-CC through 7H-CC) (Table T6). Radiolarians are also common to abundant in the foraminifer residue $>63$ and $>150 \mu \mathrm{m}$ (see "Benthic foraminifers" for more details).

Nine radiolarian datums were found in Hole U1424A (Table T4), and they could be included in the L. pylomaticus Zone (Pliocene) through the B. aquilonaris Zone (Late Pleistocene). Late Pleistocene datums include the last occurrence (LO) of Lychnocanoma sakaii (0.05 Ma) and Spongodiscus sp. (0.29 Ma) at 6.8 m CSF-A (Sample 346-U1424A-1H-CC) and $16.5 \mathrm{~m}$ CSF-A (Sample 2H-CC). A single specimen of $\mathrm{Eu}$ cyrtidium matuyamai was found at $44.9 \mathrm{~m}$ CSF-A (Sample 5H-CC). This taxon defines the top and bottom of the E. matuyamai Zone (1.03-1.98 Ma) by its occurrence interval. As the LO of Axoprunum acquilonium (1.2-1.7 Ma) co-occurs with E. matuyamai (Sample 5H-CC), together they suggest an age between 1.2 and $1.98 \mathrm{Ma}$. The Pleistocene/Pliocene boundary is close to the first occurrence (FO) of $C y$ cladophora davisiana $(2.7 \mathrm{Ma})$ at $83.0 \mathrm{~m}$ CSF-A and the $\mathrm{LO}$ of Hexacontium parviakitaensis $(2.7 \mathrm{Ma})$ at $92.4 \mathrm{~m}$ CSF-A (Sample 9H-CC). The FO of $H$. parviakitaensis (3.9-4.3 Ma) occurs at 111.5 m CSF-A (Sample $12 \mathrm{H}-\mathrm{CC}$ ). The Siphocampe arachnea group is abundant at $140.2 \mathrm{~m}$ CSF-A (Sample 15H-CC), suggesting their acme zone between 4.46 and $4.71 \mathrm{Ma}$. The base of Hole U1424A (158.9 m CSF-A; Sample 17H-CC) lies lower than the base of the $S$. arachnea group acme zone (4.71 Ma) and is younger than the FO of L. pylomaticus, suggesting these strata are younger than 5.3 Ma.

\section{Diatoms}

Diatom biostratigraphy is based on smear slides from core catcher samples. Seventeen core catcher samples were examined, and two datums were identified (Tables T4, T7). The LO of Neodenticula kamtschatica (>2.6-2.7 Ma) marks the top of Zone NPD 9 (Sample 346-U1424A-9H-CC) and the FO of Neodenticula koizumii $(<3.4-3.9 \mathrm{Ma})$ marks the base of Zone NPD 8 (Sample 346-U1424B-14H-CC). Diatom preservation is good throughout the succession. Overall, diatom abundance is low (0\%-20\%) in most of the upper part of the succession and increases (20\%-60\%) in the lower part of the succession (Fig. F22). Abundance $>60 \%$ occurs in Samples 346-U1424A-15H-CC and $17 \mathrm{H}-\mathrm{CC}$. Diatoms are not present in Samples 1H-CC, 6H-CC, and 7H-CC. Freshwater diatom species are present in Samples 1H-CC, 4H-CC, 6H-CC, $8 \mathrm{H}-\mathrm{CC}$, and $17 \mathrm{H}-\mathrm{CC}$. Opal phytoliths (land plant silica concretions) are found in Samples 5H-CC, $7 \mathrm{H}-$ CC, $8 \mathrm{H}-\mathrm{CC}, 9 \mathrm{H}-\mathrm{CC}, 12 \mathrm{H}-\mathrm{CC}, 14 \mathrm{H}-\mathrm{CC}, 16 \mathrm{H}-\mathrm{CC}$, and 17H-CC (Table T7). The presence of freshwater diatom species and phytoliths might be related to freshwater input and/or wind transportation. Diatoms are also present in the foraminifer residue $>63$ and $>150$ $\mu \mathrm{m}$ (see "Benthic foraminifers" for more details).

\section{Planktonic foraminifers}

Planktonic foraminifers were examined in core catcher samples from Holes U1424A (17 samples), U1424B (6 samples), and U1424C (4 samples) in addition to toothpick samples from Hole U1424A (11 
samples) taken after the core sections were split. Planktonic foraminifers are mainly confined to the upper part of the succession (shallower than $35.43 \mathrm{~m}$ CSF-A; Sample 346-U1424A-4H-CC) (Fig. F22). Eleven toothpick samples were examined (Table T8), and seven of these samples contained $\sim 100$ specimens, three samples contained $\sim 80$ specimens, and one sample had 21 specimens.

Relative abundance of taxa and estimates of assemblage preservation are presented in Table T8. Planktonic foraminifers are generally abundant shallower than Sample 346-U1424A-4H-CC (35.43 m CSF-A), especially in brown layers within Subunit IA (see "Lithostratigraphy" for more details), and are absent or rare below. Preservation is moderate to poor in most of the core catcher samples, and fragmentation and/or pyritization is common.

Planktonic foraminiferal assemblages shallower than Sample 346-U1424A-4H-CC (35.5 m CSF-A) are characteristic of cold, subarctic, and restricted environments. They mainly consist of Globigerina bulloides and Neogloboquadrina pachyderma (sinistral) with rare occurrences of Globigerina umbilicata, Globigerina quinqueloba, N. pachyderma (dextral), Neogloboquadrina dutertrei (= Neogloboquadrina himiensis), and Neogloboquadrina incompta and Neogloboquadrina kagaensis group (N. kagaensis and Neogloboquadrina inglei). Planktonic foraminifer Zones PF9 and PF8 are recognized based on the dominance of sinistral $\mathrm{N}$. pachyderma shallower than 35.5 m CSF-A (Fig. F20). The single occurrence of Orbulina universa in Sample 346-U1424A-17H-CC (153.82 m CSF-A) indicates an age older than 3.2 Ma (Miwa, 2014). However, this datum is poorly constrained, as shallower samples are barren of planktonic foraminifers. The LO of $N$. kagaensis (= N. inglei) was found in Samples 346U1424A-4H-2W, 135-136 cm (28.65 m CSF-A), and 346-U1424B-4H-CC (30.88 m CSF-A). This species disappeared 0.7 m.y. ago (Kucera and Kennett, 2000).

\section{Benthic foraminifers}

Benthic foraminifers were examined in core catcher samples from Holes U1424A (17 samples), U1424B (6 samples), and U1424C (4 samples) and in toothpick samples from Hole U1424A (11 samples) taken after the core sections were split. Mudline samples recovered in Holes U1424A and U1424B were also investigated. Samples with an average volume of $\sim 30 \mathrm{~cm}^{3}$ were processed from all core catchers to obtain quantitative estimates of benthic foraminiferal distribution patterns downhole. To assess assemblage composition and variability, all specimens from the $>150$ $\mu \mathrm{m}$ fraction were picked and transferred to slides for identification and counting. The presence and distribution of benthic foraminifers was additionally checked in the $63-150 \mu \mathrm{m}$ fraction to ensure that assemblages in the $>150 \mu \mathrm{m}$ fraction were representative and that small species such as phytodetritus feeders or small infaunal taxa were not overlooked.

Benthic foraminifers are rare or absent through the $\sim 160 \mathrm{~m}$ thick biosiliceous-rich succession recovered at Site U1424 (Fig. F22; Table T9). Samples 346U1424A-1H-CC through 8H-CC (0-73.17 m CSF-A) are barren. Deeper than Sample 346-U1424A-8H-CC (73.17 m CSF-A), abundance and diversity generally remain low or the samples are barren. Preservation is generally poor or moderate, except in Samples 346U1424A-17H-CC and 346-U1424B-17H-CC, where preservation improves. The assemblages consist of calcareous and agglutinated taxa, and their overall composition indicates bathyal paleodepths throughout the Pleistocene and Pliocene.

A total of 17 benthic foraminiferal taxa were identified. Census counts from core catcher and split-core section samples are presented in Table T9. Figure F22 summarizes the downcore distribution of benthic foraminifers in core catcher samples from Hole U1424A. Species commonly recorded include Martinotiella communis and Miliammina echigoensis (Table T9). Samples 346-U1424A-17H-CC (158.8 m CSF-A) and 346-U1424B-17H-CC (155.02 m CSF-A) are characterized by a more diverse assemblage, indicating substantially improved oxygenation at the seafloor at $\sim 5 \mathrm{Ma}$. The assemblage includes Cibicidoides refulgens, Eggerella bradyi, Globobulimina pacifica, Melonis barleeanus, Pullenia quinqueloba, M. echigoensis, and Quinqueloculina akneriana. These intervals do not appear to be correlative, based on hole-to-hole stratigraphic correlation (see "Stratigraphic correlation and sedimentation rates"). However, they may correspond to several transient episodes of improved deepwater circulation in the sea, although the low resolution of our sample set does not allow identification of individual events in Holes U1424A and U1424B. Sample 346-U1424C-5H-CC contains only pyritized, agglutinated foraminifers (Aschemonella spp.), which have fine-grained agglutinated walls that easily decay (Figs. F23, F24). Moderately to wellpreserved diatoms and radiolarians are common to abundant in residues $>150$ and $>63 \mu \mathrm{m}$ throughout the succession and become dominant below $\sim 80 \mathrm{~m}$ CSF-A.

\section{Ostracods}

Core catcher samples were also examined for the presence of ostracods during shipboard preparation of benthic foraminifer samples. Only one valve of 
Henryhowella cf. $H$. circumdentata (Hanai et al., 1980), a bathyal taxon, was found in Sample 346-U1424A11H-CC (Fig. F23).

\section{Mudline samples}

Mudline samples from Holes U1424A and U1424B were gently washed in order to preserve fragile agglutinated specimens with extremely low fossilization potential. The mudline sample from Hole U1424A contains only rare, organically cemented, agglutinated foraminifers including M. echigoensis, Aschemonella sp., and Rhabdammina spp. (Fig. F23). Diatoms are abundant and planktonic foraminifers are absent in the mudline sample, suggesting that calcareous tests are being dissolved in this water depth $(\sim 2800 \mathrm{~m})$.

\section{Geochemistry}

Site U1424 redrilled Site 794 (Shipboard Scientific Party, 1990). Consequently, a series of geochemistry profiles for solids, interstitial water, and volatile hydrocarbons already existed for this location (Shipboard Scientific Party, 1990; Brumsack and Zuleger, 1992; Brumsack et al., 1992; Murray et al., 1992). These profiles showed that, similar to other sites in this marginal sea, several key processes impact the geochemistry (Shipboard Scientific Party, 1990; Murray et al., 1992). In shallowly buried sediment, the modest degradation of organic carbon drives a series of microbially mediated reactions. Deeper in the sedimentary column, opal recrystallization and basalt reactions are important.

A short transit time and rapid core recovery kept geochemistry operations at Site U1424 on a fast pace. Some instrument maintenance issues also temporarily impeded progress. Given these issues and the existing knowledge, sampling for geochemistry at Site U1424 targeted intervals of maximum scientific interest. To complement data from Site 794 and to provide a backbone for new analyses, one wholeround sample for squeezing (IW-Sq) and one headspace (HS) sample for gas were collected from each full APC core (or from alternate half APC cores) in Hole U1424A. These were at the base of Section 1 and top of Section 2, respectively, in the relevant cores, unless an issue regarding sampling was identified on the catwalk. To supplement conventional water samples, we also took numerous Rhizon (IW$\mathrm{Rh}$ ) samples until they could no longer be inserted into the compacted core.

The Rhizon program at Site U1424 was designed to serve four goals. One suite of Rhizons was placed close to samples for squeezing to see whether the chemistry of IW-Rh samples matched that of IW-Sq samples for several dissolved species measured on board the ship. Although standard Rhizon sampling collects only $10 \mathrm{~mL}$ or less of water, this is a sufficient volume to analyze for $\mathrm{Cl}^{-}$(titration), $\mathrm{SO}_{4}{ }^{2-}$ and $\mathrm{Br}^{-}$(ion chromatograph), $\mathrm{NH}_{4}{ }^{+}$(spectrophotometry), and metals (inductively coupled plasmaatomic emission spectroscopy [ICP-AES]). The labor involved in collecting Rhizon samples is much less than that for squeezed samples, even though the postsampling splitting and analyses of samples requires a similar amount of time per sample.

Two more sets of Rhizons were inserted primarily for shore-based analyses. One was to obtain interstitial water for the generation of high-resolution $\mathrm{Cl}^{-}$and $\delta^{18} \mathrm{O}$ profiles. The other was to obtain interstitial water for a study of Fe speciation.

A fourth suite of Rhizons was inserted across the upper $10 \mathrm{~m}$ of Hole U1424A to determine where oxidation of ammonium and reduction of metal oxides occur at this site. Numerous box cores and piston cores have been examined in an effort to establish the depth and the importance of various microbial reactions involving $\mathrm{N}, \mathrm{Fe}$, and $\mathrm{Mn}$ (e.g., Froelich et al., 1979; Bender et al., 1989). This includes anaerobic oxidation of ammonium ("anammox"), which is an important reaction in the global $\mathrm{N}$ cycle (Dalsgaard et al., 2005). However, linkages between reactions in the uppermost few meters and those deeper in the sediment column have not been bridged fully, as exemplified by data at Site 794. Like many locations drilled over the last few decades, Site 794 has a dissolved $\mathrm{NH}_{4}{ }^{+}$profile that appears to reach zero concentration at the seafloor. However, at this site and at almost all drill sites, the first pore water sample is typically a whole-round sample from squeezing taken several meters below the seafloor. Therefore, the precise depth at which $\mathrm{NH}_{4}^{+}$goes to zero concentration is unknown. A good understanding of microbial reactions in shallowly buried sediment may also help to unravel issues with sediment color banding and magnetic minerals discussed at Sites U1422 and U1423.

At Site U1424, insertion of Rhizons into sediment became very difficult at $\sim 38 \mathrm{~m}$ CSF-A. However, reconstructions of past bottom water salinity from interstitial water profiles usually require samples extending to $\sim 50 \mathrm{~m}$ or so below the seafloor (e.g., Adkins et al., 2002). Additional samples for squeezing were thus taken from Hole U1424C. A combination of squeezing and sucking seems optimal for achieving desired liquid. 


\section{Sample summary}

During operations at Site U1424, the geochemistry group collected and analyzed a range of samples. These included (Tables T10, T11, T12) the following:

- 1 "mudline" (ML) sample.

- 40 interstitial water samples from whole-round squeezing (IW-Sq). Of these, 23 were taken from Hole U1424C, primarily to collect water for shorebased analyses of $\delta^{18} \mathrm{O}$.

- 86 interstitial water samples from Rhizons (IW$\mathrm{Rh})$.

- 29 sediment samples, mostly from interstitial water squeeze cakes but some from physical property samples, to evaluate differences between dark and light sediment horizons.

- 16 headspace (HS) gas samples.

We assume that in situ interstitial water over short depth increments has similar chemistry (although the Fe data at Site U1424, below, may challenge this basic tenet). This is generally true for IW-Sq and IW$\mathrm{Rh}$ samples from similar depth intervals. However, for some species over some depth intervals, the different sampling approaches lead to distinct chemistry. This is a recurring theme, one that we aim to understand with future work during Expedition 346 and on shore. At this juncture, it is important to note four items. First, all IW-Sq samples collected from Hole U1424A were examined and split into aliquots before any IW-Rh samples from this hole. Second, most IW-Sq samples were analyzed in batches distinct from most IW-Rh samples. Third, the number of interstitial water samples over a given depth increment is often many fewer than IW-Rh samples. Fourth, deionized water and artificial seawater, when either slowly pushed through a squeezer or slowly pulled through a Rhizon, show no anomalous concentrations of any species analyzed in the shipboard laboratory. In summary, it is difficult to ascertain the root cause of apparent deviations in the concentrations of several species because, once removed from sediment, the IW-Sq and IW-Rh samples were treated differently. However, differences are not caused by contamination.

\section{Carbonate and organic carbon}

Similar to previous sites drilled in the Japan Basin during Leg 127 (Tamaki, Pisciotto, Allan, et al., 1990) and Expedition 346 (Sites U1422 and U1423), sediment recovered at Site U1424 has low amounts of carbonate (Fig. F25). Most samples have $<1.0 \mathrm{wt} \%$. However, some samples have between 1 and $6 \mathrm{wt} \%$, and two samples, at 4.94 and $141.25 \mathrm{~m}$ CSF-A, have $\sim 32$ and $44 \mathrm{wt} \%$, respectively. The deeper of these samples is associated with a layer rich in foramin- ifers, whereas the shallower sample is associated with a layer rich in diatoms and radiolarians but where carbonate has accumulated inside the radiolarian shells (see "Lithostratigraphy" and "Biostratigraphy"). In general, the variance in carbonate content with respect to depth is similar to that obtained at Site 794 (Shipboard Scientific Party, 1990).

Regarding total organic carbon (TOC), Subunit IA (042.9 m CSF-A, see "Lithostratigraphy") has the highest values. TOC contents range from 0.3 to 1.4 $\mathrm{wt} \%$ on material from $5 \mathrm{~cm}$ thick intervals used for interstitial water squeezing and from 0.1 to $3.9 \mathrm{wt} \%$ across $2 \mathrm{~cm}$ thick intervals chosen to represent light (low TOC) and dark (high TOC) horizons (see "Physical properties"). As established by previous work (Föllmi et al., 1992; Tada et al., 1992), TOC varies significantly at the centimeter- to meter-scale in sediment from the Japan Basin, particularly in younger strata correlative with Subunit IA. The TOC contents of samples from Subunit IB (42.9-64 m CSF-A) and Unit II ( 64-158.8 m CSF-A) are generally lower $($ mean $=0.38)$ and less variable (standard deviation $=$ 0.28) than those of overlying sediment, although only a small number of samples were examined. A similar result was found at ODP Site 795 (Tamaki, Pisciotto, Allan, et al., 1990).

Sediment total nitrogen (TN) contents at Site U1424 vary much less than TOC contents. The mean value of $\mathrm{TN}$ is $0.23 \mathrm{wt} \%$. However, the maximum TN content $(0.47 \mathrm{wt} \%$ at $\sim 3.41 \mathrm{~m}$ CSF-A) is only double this amount, whereas the minimum $\mathrm{TN}$ content $(0.13$ $\mathrm{wt} \%$ at 122.25 and $141.25 \mathrm{~m}$ CSF-A) is less than half this amount. Consequently, the $\mathrm{C} / \mathrm{N}$ ratio of organic carbon appears to change significantly, from $<0.6$ to $>10$ on a molar basis. The lower $\mathrm{C} / \mathrm{N}$ values are probably incorrect because of errors in total carbon (TC) and TN measurements at low concentrations. A similar observation was made previously for sediment in the Japan Basin and may relate to temporal differences in the type of organic carbon, the preservation of organic carbon, or both (Shipboard Scientific Party, 1990). Nitrogen may also adsorb onto clay (Shipboard Scientific Party, 1990).

In summary, and despite only analyzing a small total number of samples, we were able to document the carbon chemistry of sediment sampled at Site U1424 and demonstrate its similarity to Site 794 (Shipboard Scientific Party, 1990). Total carbon content is mainly controlled by organic carbon, perhaps from mixed sources, and high amounts of carbonate occur in sporadic samples.

\section{Manganese and iron}

The dissolved $\mathrm{Mn}$ and Fe profiles (Table T11; Fig. F26) at Site U1424 show peaks in the upper $20 \mathrm{~m}$ be- 
low the seafloor and some variability with greater depth. Interstitial water obtained from squeezers and Rhizons at similar depth generally have similar Mn and Fe concentrations, although at a fine scale, some discrepancies may exist. For example, dissolved Mn concentrations at similar depth appear to be consistently higher in IW-Rh samples relative to IW-Sq samples. However, most IW-Rh samples were analyzed for Mn concentrations after different storage and in a different batch than the IW-Sq samples. In any case, the Rhizon samples lead to dissolved $\mathrm{Mn}$ and Fe profiles with a depth resolution similar to those in many piston core studies.

The Mn profile at Site U1424 is relatively smooth and fairly similar in shape to those at Sites U1422 and U1423. Mn concentrations continuously increase from less than the detection limit $(\sim 0.5 \mu \mathrm{M})$ at the seafloor to $\sim 113 \mu \mathrm{M}$ at $8.5 \mathrm{~m}$ CSF-A. Below this depth, dissolved Mn decreases rapidly to $70 \mu \mathrm{M}$ at $17.8 \mathrm{~m}$ CSF-A and then gradually decreases to $\sim 40$ $\mu \mathrm{M}$ at $60 \mathrm{~m}$ CSF-A. Manganese concentrations are relatively constant $(50-70 \mu \mathrm{M})$ from 57 to $160 \mathrm{~m}$ CSF-A.

The liberation of dissolved $\mathrm{Mn}$ at shallow burial depths ( $11 \mathrm{~m}$ CSF-A) is captured well by Rhizon sampling (Fig. F27). Presumably, this increase in interstitial water Mn concentration derives from $\mathrm{Mn}$ oxide reduction of organic matter (Froelich et al., 1979). As at Sites U1422 and U1423, the subsequent decrease in dissolved Mn below $11 \mathrm{~m}$ CSF-A and increase in dissolved Mn below $60 \mathrm{~m}$ CSF-A are likely caused by the formation and dissolution of a Mn-carbonate phase, such as rhodochrosite (Middelburg et al., 1987). The argument for such a process at Site U1424 and other sites in the Japan Basin is compelling, especially when compared with alkalinity profiles. For example, between 20 and 60 m CSF-A, dissolved Mn concentrations never approach the detection limit as they do at Sites U1423 and U1422. At deeper depths, Mn concentrations decrease to $\sim 50-70 \mu \mathrm{M}$ at Site U1424 with an alkalinity of $\sim 10$ $12 \mathrm{mM}$ (Fig. F28), but values were $\sim 20-30 \mu \mathrm{M}$ at Site U1422 with an alkalinity of $\sim 15-20 \mathrm{mM}$. Thus, below the shallow subseafloor peak, the dissolved Mn profile appears coupled to alkalinity, which mostly represents $\mathrm{HCO}_{3}{ }^{-}$at depth.

Fe concentration is below detection limit $(\sim 0.9 \mu \mathrm{M})$ at the seafloor but reaches a maximum of $\sim 47 \mu \mathrm{M}$ at $1.8 \mathrm{~m}$ CSF-A. Values decline to $3 \mu \mathrm{M}$ at $6.6 \mathrm{~m}$ CSF-A and then rise to a second relative maximum of 23 $\mu \mathrm{M}$ at $10.4 \mathrm{~m}$ CSF-A. Dissolved Fe concentrations return to below detection limit at $17 \mathrm{~m}$ CSF-A and remain at low concentrations for the rest of the hole, except for small increases centered at $\sim 50,80$, and 120 m CSF-A.

The double spikes in dissolved Fe at shallower depths ( $<20 \mathrm{~m}$ CSF-A) are captured well by the high-resolution Rhizon sampling (Fig. F27), and they may have a causal relationship to shallow Fe peaks identified at Sites U1422 and U1423 (see "Geochemistry" in the "Site U1422" chapter and "Geochemistry" in the "Site U1423" chapter [Tada et al., 2015c, 2015d]). However, the detail of the interstitial water Fe profile at Site U1424 also allows comparisons with sedimentary profiles of parameters related to Fe content and mineralogy. In particular, highs and lows in the dissolved Fe profile clearly correspond to highs and lows in magnetic susceptibility (Fig. F27).

This intriguing result suggests at least two different explanations for the interstitial water Fe profile. First, peaks and troughs in dissolved Fe reflect the dissolution and precipitation of multiple Fe-bearing phases, presumably caused by microbial consumption of organic material. However, the shallower Fe maximum is even shallower than the Mn maximum. The canonical sequence of reactions that oxidize organic matter should reduce Mn oxides at shallower depths than Fe oxides (e.g., Froelich et al., 1979). The Fe diffusion gradients with respect to depth would also be very large. Alternatively, the measured "dissolved Fe" represents the amount of very small magnetite particles that can be passed from a given sample through either the pores of Rhizons (150-200 $\mathrm{nm})$ or the pores of filters $(450 \mathrm{~nm})$ attached to the squeezers. Magnetotactic bacteria produce single-domain (35-120 nm) magnetite in shallow-marine sediment (e.g., Kopp and Kirschvink, 2008), and it is possible that we are extracting this component during the collection of interstitial water. Future work on the magnetite within the sediment or Rhizons with different pore sizes may resolve this issue.

The complete removal of Fe from $\sim 18$ to 38 m CSF-A suggests the formation of an Fe-bearing mineral. Iron sulfides may precipitate in this depth interval as HS- $^{-}$is released to interstitial water during sulfate reduction. As recognized at Sites U1422 and U1423 and further complicated by the relationship between dissolved Fe and magnetic susceptibility, the Fe story within sediment of the Japan Basin remains complex. Several Fe-bearing solids, potentially including oxides, sulfides, carbonates, and clay, can precipitate and dissolve at depth, which would influence the Fe profile. Furthermore, we are now uncertain whether we are truly measuring dissolved Fe. Shore-based studies focused on authigenic minerals, including the possible presence of bacterial magnetite, are re- 
quired to fully understand variations in the abundance of dissolved Fe and sedimentary Fe with respect to depth.

\section{Alkalinity, ammonium, and phosphate}

Alkalinity, ammonium, and phosphate (Table T11; Fig. F28) profiles at Site U1424 show trends broadly similar to those observed at Sites U1422 and U1423, but with lower concentrations for all three species. For example, the alkalinity maximum at Site U1422 is $22 \mathrm{mM}$ at $84 \mathrm{~m}$ CSF-A.

Our interpretations of the alkalinity, $\mathrm{NH}_{4}{ }^{+}$, and $\mathrm{PO}_{4}{ }^{3-}$ profiles at Site U1424 are the same as for previous locations. Microbial decomposition of solid organic matter releases $\mathrm{HCO}_{3}{ }^{-}, \mathrm{NH}_{4}{ }^{+}$, and $\mathrm{PO}_{4}{ }^{3-}$ to interstitial water, whereas precipitation of authigenic minerals removes some of the $\mathrm{HCO}_{3}{ }^{-}$and $\mathrm{PO}_{4}{ }^{3-}$ at depth. The lower concentrations of alkalinity, $\mathrm{NH}_{4}{ }^{+}$, and $\mathrm{PO}_{4}{ }^{3-}$ at Site U1424 relative to Sites U1422 and U1423, therefore, indicate less organic decomposition over time. The general lack of $\mathrm{CH}_{4}$ at Site U1424 (below) further supports this interpretation. In terms of paleoceanographic objectives, this may suggest a smaller flux of organic carbon to the seafloor at Site U1424 during the late Quaternary relative to the other locations.

As for $\mathrm{Mn}$ and $\mathrm{Fe}$, the alkalinity, $\mathrm{NH}_{4}{ }^{+}$, and $\mathrm{PO}_{4}{ }^{3-}$ profiles demonstrate the ability of Rhizons to enhance the depth resolution of interstitial water profiles (Figs. F28, F29). Alkalinity and $\mathrm{NH}_{4}{ }^{+}$concentrations determined on samples from Rhizons and squeezers are similar at Site U1424. Rhizon and squeeze samples also reveal the same $\mathrm{PO}_{4}{ }^{3-}$ trend, although $\mathrm{PO}_{4}{ }^{3-}$ concentrations are noticeably higher in IW-Rh samples relative to IW-Sq samples at concentrations higher than $\sim 20 \mu \mathrm{M}$.

The high-resolution $\mathrm{NH}_{4}^{+}$profile in shallow sediment (Fig. F29) is of particular interest. The nine Rhizons taken within $2 \mathrm{~m}$ of the mudline provide an unusual look at processes occurring between the seafloor and deeper sediment. Dissolved Mn and alkalinity both increase across this depth interval (Fig. F27). By contrast, the $\mathrm{NH}_{4}^{+}$profile has a kink at 40 $\mathrm{cm}$. Shallower than this depth, concentrations are $\sim 10 \mu \mathrm{M}$ and essentially those of bottom water, as determined by measuring the mudline sample. Below this depth, concentrations increase rapidly. The Mn and alkalinity profiles clearly show that core disturbance and seawater mixing do not cause the inflection in the $\mathrm{NH}_{4}^{+}$profile. Instead, the kink in the $\mathrm{NH}_{4}{ }^{+}$concentration gradient, which happens to mark the depth separating overlying red sediment from underlying green sediment (see "Lithostratigraphy"), likely indicates a change in $\mathrm{NH}_{4}{ }^{+}$flux. Two processes could induce such a change. One explanation would be $\mathrm{NO}_{3}{ }^{-}$diffusing downhole from the seafloor to $40 \mathrm{~cm}$, where it begins oxidizing organic matter and producing $\mathrm{NH}_{4}{ }^{+}$(e.g., Froelich et al., 1979). Alternatively, $\mathrm{NH}_{4}{ }^{+}$generated at depth from the degradation of organic material by other electron acceptors, such as dissolved $\mathrm{SO}_{4}{ }^{2-}$, diffuses upward and reacts. The postulated reaction could involve $\mathrm{O}_{2}$ (nitrification) or $\mathrm{NO}_{2}^{-}$(anammox). Onshore flux calculations regarding pore water at Site U1424 should reveal more about such processes.

\section{Volatile hydrocarbons}

Methane is the only hydrocarbon gas in the headspace samples at Site U1424. No ethane or heavier hydrocarbons were detected. Compared to $\mathrm{CH}_{4}$ concentrations at Sites U1422 and U1423, values at Site U1424 are extremely low, consistently less than $\sim 5$ ppmv through the bottom of the hole (Fig. F30). Nonetheless, there is a $\mathrm{CH}_{4}$ profile at Site U1424 (Fig. F31). The $\mathrm{CH}_{4}$ concentration is zero in the shallowest sample at $1.5 \mathrm{~m}$ CSF-A. Deeper, values increase to a maximum of $\sim 5$ ppmv at $46 \mathrm{~m}$ CSF-A and then decrease to 0 ppmv at $131 \mathrm{~m} \mathrm{CSF-A} \mathrm{(Table} \mathrm{T12).}$

With such low $\mathrm{CH}_{4}$ concentrations, a prominent sulfate-methane transition (SMT) should not exist at Site U1424. Instead, low $\mathrm{CH}_{4}$ concentrations might coincide with significant concentrations $(>10 \mathrm{mM})$ of dissolved $\mathrm{SO}_{4}{ }^{2-}\left(\mathrm{D}^{\prime} \mathrm{Hondt}\right.$ et al., 2004). Indeed, this is the case (Fig. F31).

\section{Sulfate and barium}

Sulfate concentrations demonstrate a classic concave downward profile (Table T11; Fig. F31) indicative of the continuous use of $\mathrm{SO}_{4}{ }^{2-}$ to oxidize organic material through the entire sediment column that was sampled. Unlike as at Sites U1422 and U1423, $\mathrm{SO}_{4}{ }^{2-}$ does not reach zero concentration. The general absence of $\mathrm{CH}_{4}$ at Site U1424 further supports $\mathrm{SO}_{4}{ }^{2-}$ being the final electron acceptor within the upper $160 \mathrm{~m}$ of sediment at this location. This conclusion was also reached at Site 794, which has a similar $\mathrm{SO}_{4}{ }^{2-}$ profile.

The presence of $\mathrm{SO}_{4}{ }^{2-}$ throughout the entire sampled sequence prohibits the dissolution of barite. Consequently, Ba concentrations in interstitial water remain low throughout the sediment at Site U1424 (Fig. F32). This profile is contrary to Sites U1422 and U1423, where Ba concentrations increase dramatically at depths where barite passes below the SMT.

By focusing on small-scale variations in dissolved $\mathrm{Ba}$, a disparity between IW-Sq and IW-Rh samples be- 
comes apparent. Ba concentrations measured on the Rhizon samples remain low and essentially equivalent to those of bottom water $(<2.5 \mu \mathrm{M})$ for the upper $40 \mathrm{~m}$ below the seafloor. By contrast, Ba concentrations measured on the squeezed samples increase to $10-20 \mu \mathrm{M}$ immediately below the seafloor and remain at this level throughout the upper $40 \mathrm{~m}$. Unlike for some other species, the discrepancy is consistent across numerous samples, independent of other possible factors, such as batch analysis or processing time. Either $\mathrm{Ba}$ is being removed from water during sampling by Rhizons, $\mathrm{Ba}$ is being added to water during sampling by squeezing, or both. Significant dilution of Rhizon water samples with deionized water or seawater is not a valid explanation because several other species examined have very similar dissolved concentrations across IW-Sq and IW-Rh samples. It is possible that small amounts of barite precipitate during Rhizon sampling, as this would not impact concentrations of other species significantly. Alternatively, and somewhat analogous to one explanation for the dissolved Fe data, very fine grains of barite may enter the interstitial water obtained through squeezing. We note that barite grains $<0.45$ $\mu \mathrm{m}$ in diameter, the pore size of the filter, can be found in marine sediment (Griffith and Paytan, 2012).

\section{Calcium, magnesium, and strontium}

The Ca, Mg, and Sr profiles at Site U1424 (Table T11; Fig. F33) are similar to those for the upper $160 \mathrm{~m}$ at Site 794 (Shipboard Scientific Party, 1990). Over the depth drilled, dissolved $\mathrm{Ca}$ and $\mathrm{Sr}$ increase slightly, whereas dissolved $\mathrm{Mg}$ decreases slightly. These profiles exhibit minimal change in concentration gradients with respect to depth, being primarily dominated by alteration of ash and basalt below the base of drilling, as well as diffusion (Murray et al., 1992).

The Ca profile shows a slight increase in concentration downhole throughout the sediment column (Fig. F33), suggesting a minimal amount of net calcium carbonate formation or dissolution. As noted above, the relatively low level of organic matter decomposition at this location maintains alkalinity $<14 \mathrm{mM}$ throughout the drilled sediment column (Fig. F28). Apparently, this concentration is insufficient for precipitation of calcium carbonate phases. However, it is worth noting that the solubility of calcite is $\sim 2$ orders of magnitude greater than that of rhodochrosite. The latter phase may very well exist in sediment at Site U1424.

The Sr profile is problematic because the IW-Rh samples show a high degree of scatter (Fig. F33). We presently lack an explanation for these data but can ex- clude addition of $\mathrm{Sr}$ as water passes through the Rhizons.

\section{Chlorinity and sodium}

$\mathrm{Cl}^{-}$and $\mathrm{Na}$ concentrations of the mudline sample (543 and $571 \mathrm{mM}$, respectively) are similar to those of inferred present-day Japan Sea Proper Water (JSPW) (545 and $468 \mathrm{mM}$ ) (Table T10 in the "Methods" chapter [Tada et al., 2015b]). Below the seafloor, from 5 to $60 \mathrm{~m}$ CSF-A, $\mathrm{Cl}^{-}$concentrations are significantly lower than present-day bottom water values (Table T11; Fig. F34). This occurs at all sites drilled so far during Expedition 346 and is both interesting and important. As discussed in "Geochemistry" in the "Site U1423" chapter (Tada et al., 2015d), we suggest the interval with low $\mathrm{Cl}^{-}$concentrations represents a nonsteady-state transient because the deep water of the marginal sea was significantly fresher during the Last Glacial Maximum. At Sites U1422 and U1423, Na concentrations were distinctly lower than bottom water values when $\mathrm{Cl}$ concentrations were low at shallow subseafloor depths. At Site U1424, the Na profile shows considerable scatter and lacks evidence for fresher interstitial water (Fig. F34).

\section{Potassium}

The first-order trend of the dissolved $\mathrm{K}$ profile (Table T11; Fig. F34) is an overall decrease with depth. This decrease in $\mathrm{K}$ concentrations continues to deeper depths at Site 794, reaching $\sim 1 \mathrm{mM}$ at 540 meters below seafloor (mbsf) and the contact with basalt (Shipboard Scientific Party, 1990). The profile probably results from the alteration of numerous ash layers within the sediment column or basalt (Murray et al., 1992), as both can incorporate potassium.

$\mathrm{K}$ concentration of the mudline sample is $10.3 \mathrm{mM}$, which is very close to the $10.2 \mathrm{mM}$ predicted for JSPW (Table T10 in the "Methods" chapter [Tada et al., 2015b]). Therefore, a curious feature of the K profile is enrichment in shallow sediment. Concentrations increase from the above bottom water value to 12-13 $\mathrm{mM}$ just below the seafloor. This jump in $\mathrm{K}$ concentration also occurs at Sites U1422 and U1423, although it is captured in more detail at Site U1424. The increase in $\mathrm{K}$ may relate to the dissolution of a K-bearing phase or formation of an authigenic mineral that can exchange $\mathrm{K}^{+}$with other cations such as $\mathrm{NH}_{4}^{+}, \mathrm{Li}^{+}$, or $\mathrm{Na}^{+}$.

\section{Lithium and boron}

Lithium increases from $\sim 26 \mu \mathrm{M}$ in the mudline sample to $68 \mu \mathrm{M}$ in the deepest sample with an inflection at 20 m CSF-A (Table T11; Fig. F35). Analyses 
of interstitial water samples from Site 794 show that this trend continues until $\sim 350 \mathrm{~m}$ CSF-A. At this depth, which corresponds to the opal-A/opal-CT transition, Li concentrations decrease (Murray et al., 1992). Over this greater depth scale, the $\mathrm{Li}$ profile mimics the Si profile. This was originally interpreted as reflecting Li release by dissolution of diatoms and subsequent Li removal by alteration of ash, basalt, or authigenic clay formation (Shipboard Scientific Party, 1990; Murray et al., 1992). The higher resolution sampling across the upper $160 \mathrm{~m}$ shows that in the shallow sediment column Li profile is concave upward, whereas the Si profile is concave downward. Trends and concentrations of Li from IW-Sq and IWRh samples agree well.

The B profile shows quite a bit of scatter in both IWSq and IW-Rh samples until $65 \mathrm{~m}$ CSF-A. Deeper than this depth, B concentrations become fairly constant at $\sim 400 \mu \mathrm{M}$.

\section{Silica}

Overall, dissolved Si exhibits a concave downward profile (Table T11; Fig. F35), presumably explained by biogenic Si dissolution throughout most of the sampled sediment column. Because the solubility of opal increases with higher temperature and because the mass of silica in sediment is much greater than that in surrounding pore water, dissolved Si concentrations should increase with depth. Interestingly, however, the dissolved $\mathrm{Si}$ profile suggests the situation is more complicated at Site U1424.

The IW-Rh samples show anomalies over the upper $20 \mathrm{~m}$ below the seafloor, where Si concentrations vary significantly over short depth. These lows and highs in dissolved Si may indicate zones of biogenic silica dissolution or precipitation. More obvious is a $\sim 20 \mathrm{~m}$ thick zone of anomalously low $\mathrm{Si}$ concentrations centered around $\sim 56 \mathrm{~m} \mathrm{CSF-A,} \mathrm{which} \mathrm{is} \mathrm{appar-}$ ent in squeezed samples from both Holes U1424A and U1424C. Silicon may be entering an authigenic phase at this horizon, although a Si sink is not identified. We note the depth interval corresponds to an interval of slower sedimentation rates (see "Stratigraphic correlation and sedimentation rates").

\section{Additional Rhizon commentary}

As noted in previous paragraphs and shown in various figures, the water samples collected from Rhizons have fairly similar chemistry to water samples collected from squeezers. However, there appear to be subtle differences, although the cause of such variance remains uncertain with the samples, processing, and analyses at Site U1424. A suite of closely spaced IW-Sq and IW-Rh samples, analyzed for range of dissolved species, should prove illuminating.

The geochemistry program at Site U1424 uncovered two issues regarding Rhizon samples not acknowledged in previous chapters or elsewhere. The total number of Rhizons collected over several hours in Hole U1424A (87) overwhelmed the geochemistry laboratory. The current Laboratory Information Management System (LIMS) data system for sample documentation was not built with Rhizon sampling in mind. Basically, the ability to collect very large numbers of samples needs to be tempered with the reality of labeling and processing such samples. However, we predict that Rhizon sampling will become more prevalent in shipboard geochemical studies, and the added benefits they bring to expeditions far outweigh these temporary logistical issues.

We also experienced difficulties inserting Rhizons into the sediment of Core 346-U1424A-5H and deeper. A similar depth limitation to Rhizon sampling was encountered during IODP Expedition 302 (Dickens et al., 2007) and may be related to compaction of clay-rich sediment.

\section{Preliminary conclusions}

The geochemical analyses performed on samples from Site 794 provided a framework for Expedition 346 geochemists to build upon. We chose to supplement the previous work, mostly with higher resolution sampling focused on shallower depths, where degradation of organic material influences interstitial water chemistry prominently. This sampling included extensive use of Rhizons for the dual purposes of making comparisons of interstitial water chemistry between sampling techniques and of documenting thin sediment horizons marked by changes in concentration gradients of dissolved species.

Where comparable in terms of depth and analyses, the geochemistry results at Site U1424 are similar to those at Site 794. At this location, organic carbon and biogenic silica enter the sediment column and drive a series of reactions, some involving other sedimentary components. Alteration of underlying basalt also impacts the interstitial water profile. The primary, large-scale difference in geochemistry between Site U1424 and other drill sites within the Japan Basin is that the long-term accumulation of organic matter is significantly lower.

The Rhizon sampling program added a new dimension to geochemistry at this location and may at future drill sites in general. The dissolved $\mathrm{Fe}$ profile shows major peaks that clearly correspond in depth 
to sediment intervals with relatively high magnetic susceptibility. However, we remain uncertain whether Fe, before the addition of nitric acid and ICP-AES analysis, was dissolved in water or instead occurred as very small particles of magnetite. The dissolved $\mathrm{NH}_{4}{ }^{+}$profile drops to zero concentration at $\sim 0.40 \mathrm{~m}$ CSF-A and where the color of sediment changes from red to green. These changes in the $\mathrm{NH}_{4}{ }^{+}$gradient may be controlled by nitrification or anammox but ultimately link the shallow nitrogen cycle discussed in piston core studies to the deep nitrogen pool documented in drill cores.

\section{Paleomagnetism}

\section{Paleomagnetic samples and measurements}

Paleomagnetic investigations at Site U1424 included the measurement of magnetic susceptibility of whole-core and archive-half split-core sections and of natural remanent magnetization (NRM) of archive-half sections. NRM was measured before and after alternating field (AF) demagnetization with a $20 \mathrm{mT}$ peak field for all core sections from Hole U1424A. Because of increased core flow and limited measurement time, NRM of core sections from Holes U1424B and U1424C were measured only after 20 $\mathrm{mT}$ AF demagnetization at every $5 \mathrm{~cm}$ interval. The FlexIT core orientation tool (see "Paleomagnetism" in the "Methods" chapter [Tada et al., 2015b]) was used to orient a total of 16 APC collected cores from Cores 346-U1424A-2H through $17 \mathrm{H}$. The APC core orientation data for Hole U1424A are reported in Table T13.

We collected one paleomagnetic discrete cube sample (see "Paleomagnetism" in the "Methods" chapter [Tada et al., 2015b]) from the first section of each APC core in Hole U1424A and occasionally from deep sections when the first section was not suitable for collecting a discrete cube sample (Fig. F36A). Stepwise AF demagnetization on seven discrete samples from Hole U1424A was performed at successive peak fields of $0,5,10,15,20,30,40,50$, and $60 \mathrm{mT}$ to verify the reliability of the split-core measurements and to determine the demagnetization behavior of the recovered sediment. Depth levels where the measured discrete samples were collected are marked as orange triangles along the inclination data column in Figure F36A. To avoid potential anhysteretic remanent magnetization (ARM) acquisition during the AF demagnetization, which was observed in discrete sample measurements from Sites U1422 and U1423, especially at high AF peak fields, we followed the protocol of Expedition 318 Scientists (2011) to demagnetize and measure the samples multiple times at each demagnetization level. The measurements acquired at each demagnetization step were then averaged to cancel out potential ARM acquisition during AF demagnetization (see "Paleomagnetism" in the "Methods" chapter [Tada et al., 2015b]).

We processed data extracted from the shipboard LIMS database by removing measurements collected from disturbed and void intervals and measurements that were made within $10 \mathrm{~cm}$ of the section ends, which are slightly biased by edge effects. For declination data from cores in Hole U1424A where FlexIT tool data are available, we corrected the declination values for each core using the estimated orientation angles. A modified version of the UPmag software (Xuan and Channell, 2009) was used to analyze the NRM data of both the split-core section and the discrete cube samples. The disturbed and void intervals used in this process are reported in Table T14. The processed NRM inclination, declination, and intensity data after $20 \mathrm{mT}$ AF demagnetization are reported in Table T15 and shown in Figure F36.

\section{Natural remanent magnetization and magnetic susceptibility}

Compared to Sites U1422 and U1423, NRM intensity of cores from Site U1424 is generally higher and relatively stable. NRM intensity after $20 \mathrm{mT}$ AF demagnetization in all three holes is similar in magnitude for overlapping intervals, mostly ranging from $\sim 10^{-4}$ to $10^{-2} \mathrm{~A} / \mathrm{m}$. For sediment recovered from the uppermost $\sim 25 \mathrm{~m}$ of the holes, NRM intensity after $20 \mathrm{mT}$ demagnetization is on the order of $10^{-2} \mathrm{~A} / \mathrm{m}$. NRM intensity then decreases downcore to the order of $10^{-4}$ to $10^{3} \mathrm{~A} / \mathrm{m}$ from $\sim 25 \mathrm{~m}$ CSF-A until the bottom of the holes.

The AF demagnetization behavior of the seven measured discrete samples is illustrated in Figure F37. Declination and inclination values acquired from the discrete sample measurement generally agree well with the split-core measurements after $20 \mathrm{mT}$ AF demagnetization. All samples exhibit a steep, normal overprint that was generally removed after AF demagnetization at peak fields of $\sim 10-15 \mathrm{mT}$, demonstrating that the $20 \mathrm{mT}$ AF demagnetization is, in general, sufficient to eliminate the overprint. Discrete sample measurements acquired using the Expedition 318 Scientists (2011) protocol show generally reduced ARM acquisition. However, some measured samples still appear to acquire remanence during AF demagnetization (e.g., Fig. F37D, F37G). This is possibly related to changes in the ambient field on the ship during the measurements and the fact that some of the samples are too weak to be 
measured accurately using the shipboard superconducting rock magnetometer.

Magnetic susceptibility measurements were taken on whole cores from all three holes as part of the Whole-Round Multisensor Logger (WRMSL) analysis and on archive-half sections using the Section Half Multisensor Logger (SHMSL) (see "Physical properties"). The WRMSL acquired susceptibility was stored in the database in raw meter units. These were multiplied by a factor of $0.68 \times 10^{-5}$ to convert to the dimensionless volume SI unit (Blum, 1997). A factor of $(67 / 80) \times 10^{-5}$ was multiplied by the SHMSL acquired susceptibility stored in the database. Magnetic susceptibility varies between $10 \times 10^{-5}$ and $50 \times 10^{-5} \mathrm{SI}$ for sediment from the uppermost $\sim 25 \mathrm{~m}$ of the holes and is generally $<10 \times 10^{-5}$ SI for sediment from deeper than 25 m CSF-A (Fig. F36, fourth panel). Magnetic susceptibility measurement is consistent between the two instruments and, in general, mimics NRM intensity, suggesting that the magnetic minerals that carry NRM are the same as, or at least coexist with, those that dominate magnetic susceptibility.

\section{Magnetostratigraphy}

Paleomagnetic inclination and declination data of Site U1424 appear to show patterns that allow for the determination of magnetic polarity for all sediment sequences recovered in all holes. Both paleomagnetic declination and inclination after $20 \mathrm{mT} \mathrm{AF}$ demagnetization were used when possible for the magnetostratigraphic interpretation at this site. The geomagnetic field at the latitude of Site U1424 $\left(40.19^{\circ} \mathrm{N}\right)$ has an expected inclination of $\sim 59.38^{\circ}$, assuming a geocentric axial dipole field model, which is sufficiently steep to determine magnetic polarity in APC cores that lack horizontal orientation. We identified almost all major reversals during the Pliocene and Pleistocene at Site U1424 (Table T16).

Hole U1424A clearly recorded the Brunhes/Matuyama boundary $(0.781 \mathrm{Ma})$ at $\sim 24.8 \mathrm{~m}$ CSF-A, the Olduvai Subchron (C2n, 1.778-1.945 Ma) between $\sim 54.3$ and $58.8 \mathrm{~m}$ CSF-A, the Matuyama/Gauss boundary $(2.581 \mathrm{Ma})$ at $\sim 75.7 \mathrm{~m} \mathrm{CSF}-\mathrm{A}$, and the Gauss/Gilbert boundary (3.596 Ma) at $\sim 109.85 \mathrm{~m}$ CSF-A. In Hole U1424B, the Brunhes/Matuyama boundary (0.781 Ma) was identified at $24.5 \mathrm{~m}$ CSF-A, the Olduvai Subchron (C2n, 1.778-1.945 Ma) was identified between $\sim 54.45$ and $58.65 \mathrm{~m}$ CSF-A, and the Matuyama/Gauss (2.581 Ma) and the Gauss/Gilbert $(3.596 \mathrm{Ma})$ boundaries were identified at $\sim 74.7$ and $\sim 107.7$ m CSF-A, respectively. Hole U1424B also recorded the Mammoth Subchron (3.207-3.330 Ma) between $~ 94.6$ and $98.2 \mathrm{~m}$ CSF-A, the Nunivak Sub- chron (4.493-4.631 Ma) between $\sim 142.2$ and 147.2 $\mathrm{m}$ CSF-A, and the top of the Sidufjall Subchron $(4.799 \mathrm{Ma})$ at $\sim 151.4 \mathrm{~m}$ CSF-A. The four APC cores (346-U1424C-4H through $7 \mathrm{H}$ ) measured for Hole U1424C clearly recorded the Olduvai Subchron (C2n, 1.778-1.945 Ma) between $\sim 54.45$ and $59.7 \mathrm{~m}$ CSF-A. The polarity boundaries mentioned above are all associated with clear switches in inclination data as well as $\sim 180^{\circ}$ shifts in raw and oriented declination values and are mostly not from the ends of cores that are more easily affected by drilling. Our interpretations agree well with the biostratigraphic events identified in Hole U1424A (see "Biostratigraphy") and are consistent with the limited discrete sample measurements that show good demagnetization behavior. For instance, the discrete sample from 8.09 m CSF-A in Hole U1424A (Fig. F37A) clearly shows stable and positive inclination likely acquired during the Brunhes Chron. A discrete sample from $66.62 \mathrm{~m}$ CSF-A in Hole U1424A (Fig. F37C) appears to record negative inclination that is consistent with the interpreted reversed Chron C2r.2r (bottom of the Matuyama).

In addition to the polarity boundaries mentioned above, many short subchrons during the Pliocene and the Pleistocene also appear to be recorded at Site U1424. The positive inclination intervals between $\sim 31.3$ and $36.6 \mathrm{~m}$ CSF-A in Hole U1424A, 30.4 and $35.5 \mathrm{~m}$ CSF-A in Hole U1424B, and 31.6 and $37.2 \mathrm{~m}$ CSF-A in Hole U1424C are interpreted as the Jaramillo Subchron (0.988-1.072 Ma). All three holes appear to record very short $(\sim 1 \mathrm{~m})$ positive inclination intervals right below the Jaramillo and Olduvai Subchrons. These intervals could be interpreted as the Cobb Mountain (1.173-1.185 Ma) and Reunion Subchrons (2.128-2.148 Ma) (see Table T16 for detailed depth levels). However, higher resolution postcruise paleomagnetic investigations are needed to confirm this interpretation. Within the identified Gauss Chron, the Mammoth Subchron is recorded in Hole U1424B between 94.6 and $98.2 \mathrm{~m}$ CSF-A and possibly between $\sim 94.5$ and $98 \mathrm{~m}$ CSF-A in Hole U1424A. The Kaena Subchron (3.032-3.116 Ma), however, is not very well recorded in both holes. The depth intervals with a slight tendency of more shallow and negative inclination values between $\sim 89.95$ and 92.5 $\mathrm{m}$ CSF-A in Hole U1424A and $\sim 87.5$ and $90.95 \mathrm{~m}$ CSF-A in Hole U1424B could be interpreted as the Kaena Subchron. These intervals appear to coincide with a low in NRM intensity in both holes, and the top and bottom of the intervals are associated with large changes in declination.

Near the bottom of Holes U1424A and U1424B, a few positive inclination intervals are recorded within the identified Gilbert Chron. The boundaries of 
these positive inclination intervals are better recognized in Hole U1424B and are accompanied by $\sim 180^{\circ}$ shifts in declinations. We interpret the $\sim 142.2-147.2 \mathrm{~m}$ CSF-A interval in Hole U1424B as the Nunivak Subchron (4.493-4.631 Ma). In Hole U1424A, the Nunivak Subchron is recorded within $\sim 141.6-145.6 \mathrm{~m}$ CSF-A. The bottom $\sim 4 \mathrm{~m}$ interval in Hole U1424B recorded part of the Sidufjall Subchron (4.799-4.896 Ma), with the top of the Sidufjall Subchron occurring at $\sim 151.4 \mathrm{~m}$ CSF-A. Hole U1424A appears to have recorded the Sidufjall Subchron between $\sim 150$ and $153.4 \mathrm{~m}$ CSF-A and the top of the Thvera Subchron $(4.997 \mathrm{Ma})$ at $~ 156.5 \mathrm{~m}$ CSF-A. The Cochiti Subchron (4.187-4.3 Ma) is not very well recorded in either Holes U1424A or U1424B.

\section{Physical properties}

Site U1424 is a redrill of Site 794 (Tamaki, Pisciotto, Allan, et al., 1990), and therefore there are similarities between the two sites, although some differences do occur as described herein. Site U1424 is also largely analogous to the two previous Expedition 346 sites (U1422 and U1423) with a highly variable lithology in Unit I, with alternating organic-rich and hemipelagic sediment, and a more homogeneous hemipelagic Unit II (see "Lithostratigraphy"). Physical properties primarily reflect the lithology of the sediment and only secondarily reflect diagenetic or high-pressure/high-temperature processes, and therefore there was no need to define units independent of the lithologic units for this site. The same suite of whole-round and split-core logging as well as discrete sample properties that were measured at Site U1423 were also performed at Site U1424 and are presented in Figures F38, F39, and F40.

\section{Thermal conductivity}

Thermal conductivity was measured once per core using the full-space probe, usually near the middle of Section 4 . Overall, thermal conductivity values range from 0.7 to $1.0 \mathrm{~W} /(\mathrm{m} \cdot \mathrm{K})$, without a clear increasing trend with depth. However, thermal conductivity follows porosity and gamma ray attenuation (GRA) bulk density, and thus, in part, lithology, with broad lows of $\sim 0.8 \mathrm{~W} /(\mathrm{m} \cdot \mathrm{K})$ near the seafloor (i.e., uppermost $20 \mathrm{~m}$ CSF-A), in Subunit IIA, and at the bottom of Subunit IIB.

\section{Moisture and density}

GRA bulk sediment density at Site U1424 is largely similar in pattern to Site 794 as well as Sites U1422 and U1423. Unit I displays strong high-frequency variability (i.e., decimeter- to multimeter-scale) within a general range between 1.2 and $1.8 \mathrm{~g} / \mathrm{cm}^{3}$ (Fig. F38). This variability is gradually suppressed in Subunit IIA and reaches a minimum in Subunit IIB. Subunit IIB is also characterized by a drop in density associated with a clear increasing trend with depth. As at previous sites, variability in Unit I appears to come from the massive very dark layers that exhibit lower bulk density than the rest of the sediment. However, an attempt to confirm this via discrete measurements was inconclusive (Fig. F39). Higher density values typical for Subunits IB and IIA are probably due to an increase of terrigenous materials from turbidites and a general increase in terrigenous fraction in hemipelagics (see "Lithostratigraphy"). The generally lower density observed in Subunit IIB likely reflects the increasing diatom content within this lithologic unit. Unlike the previously drilled sites, a sharp reduction in density that is noticeable in $P$-wave data occurs at $\sim 138 \mathrm{~m} \mathrm{CSF-A}$ in Hole U1424A and $133 \mathrm{~m}$ CSF-A in Hole U1424B and suggests an abrupt change in sedimentary conditions. This shift correlates with a centimeter-scale tephra layer that represents a significant boundary between dark gray bioturbated sediment (above) and brown sediment (below), observed at $138.08 \mathrm{~m}$ CSF-A in Hole U1424A (Sample 346-U1424A-15H-6, 28 cm) and at 133.24 m CSF-A in Hole U1424B (Sample 346U1424B-15H-5, 102 cm) (see "Lithostratigraphy"). This may or may not reflect a depositional hiatus (see "Lithostratigraphy"), as the age model may be too coarse to detect it (see "Biostratigraphy"). Discrete wet bulk density and derived parameters (i.e., porosity and water content) agree well with the primary trends in GRA bulk density (Fig. F39). Overall, bulk sediment density decreases with depth, which is contrary to the typical trend seen in marine sediment when subject to increased compaction and dewatering with depth. The decrease in density with depth can be explained by the downhole increase in diatom content. Diatoms have relatively high intraparticle porosity and pack well without breaking during compaction (Tada and Iijima, 1983; Tamaki, Pisciotto, Allan, et al., 1990). The downhole decrease in grain density is in agreement with this petrophysical model.

\section{Magnetic susceptibility}

Whole-core magnetic susceptibility closely tracks point magnetic susceptibility (SHMSL) with mean values for the site between $10 \times 10^{-5}$ and $20 \times 10^{-5} \mathrm{SI}$. Several additional horizons downhole reach to and above $100 \times 10^{-5} \mathrm{SI}$. In contrast to previous Sites U1422 and U1423, the SMT zone is not prominent at Site U1424, suggesting a weaker diagenetic influence on formation and destruction of magnetic minerals 
(in agreement with results from "Geochemistry"), leading to better preservation of the primary magnetic carriers (see "Paleomagnetism").

\section{Natural gamma radiation}

NGR shows strong high-amplitude cyclicity in Subunit IA and gradually muted variability from Subunit IB to the bottom of the hole (Fig. F38). NGR counts range from 20 to $80 \mathrm{cps}$ in Unit I and decrease to between 20 and $40 \mathrm{cps}$ in Unit II. This was also recorded at the previous drilled sites. This variability in NGR may be explained by high uranium content associated with massive organic-rich layers in Unit I whereas Unit II is enriched in nonradioactive elements (diatoms and other siliceous components, see "Lithostratigraphy"). The meter-scale pattern of the total NGR counts is very similar to the ones at Sites U1422 and U1423. At the bottom of Subunit IIB at Site U1424, very low NGR counts are encountered and the transition to this state is very abrupt from the sediment immediately shallower, which could be suggestive of a hiatus that was not encountered at previous sites (see also discussion about GRA density above).

\section{Compressional wave velocity}

Compressional $P$-wave velocity was measured with the WRMSL in Sections 1,2, and 3 of each core for Holes U1424A, U1424B, and U1424C following the same strategy as at Site U1423. The combined $P$-wave velocity data set (Fig. F38) shows meter-scale cyclicity on a clear increasing trend with depth. Velocity ranges between 1470 and $1570 \mathrm{~m} / \mathrm{s}$, and the general influence of the changing lithology is less prominent when compared to other physical properties. In the lowermost $20 \mathrm{~m}$ of the drilled hole, $P$-wave velocity is consistently and uniformly higher than in sediment, suggesting a possible hiatus (see above).

\section{Vane shear stress}

Undrained shear strength shows a stable increase from the seafloor to $\sim 110 \mathrm{~m}$ CSF-A in Hole U1424 through all lithologic units, reaching a maximum value of $\sim 100 \mathrm{kPa}$ (Fig. F39). Shear strength abruptly decreases between 115 and 130 CSF-A, where a clayrich interval occurs in the otherwise diatomaceous oozes of Subunit IIB.

\section{Diffuse reflectance spectroscopy}

Similar to the previous drilled sites, spectral reflectance data measured on the split archive-half sections at Site U1424 show high variability, especially in Unit I, reflecting the variegated colors of the decimeter- to centimeter-scale lithologic packages (Fig.
F40). Subunit IA is generally characterized by high variability in luminance $\left(\mathrm{L}^{*}\right)$, red-green ratio $\left(\mathrm{a}^{*}\right)$, and yellow-blue ratio $\left(b^{*}\right)$, as very dark brown to black organic-rich bands occur here often and alternate with lighter olive and green hemipelagic sediment. An $\sim 50 \mathrm{~cm}$ thick section of red and black sediment that occurs below the mudline (sediment/ bottom water interface), and inferred to contain $\mathrm{Fe}$ to Mn (oxy)hydroxides, is clearly indicated by the $\mathrm{a}^{\text {* }}$ parameter (see also "Geochemistry"). In Subunits IB and IIA, the decrease in the number of the dark layers can be seen in both $L^{*}$ and $b^{*}$. Subunit IIB shows suppressed variability in all three colorimetric parameters, as the dark bands disappear altogether.

\section{Summary}

Physical properties at Site U1424 are largely similar to previous drilled sites with the exception of a possible hiatus at the bottom of the hole (see also "Lithostratigraphy"). Unit I, with cyclical physical properties driven by the occurrence of thick, massive organic-rich dark layers, transitions into Unit II, with more subdued variability in physical properties that is largely due to alternating hemipelagic and biogenic silica-rich sediment. Magnetic susceptibility is less influenced by redox processes than at previous sites, whereas $P$-wave and shear stress data show consistent increasing trends downhole because of less degassing. Reflectance data best capture the lithologic and diagenetic variability at this site at the decimeter- to centimeter-scale.

\section{Downhole measurements}

\section{In situ temperature and heat flow}

APCT-3 downhole temperature measurements were performed in Hole U1424A at two depths, including the mudline. In situ temperature was $4.45^{\circ} \mathrm{C}$ at 35.3 $\mathrm{m}$ CSF-A. Because this value was in good agreement with the in situ temperature data set acquired at the same site during Leg 127 (Site 794 [Shipboard Scientific Party, 1990]), no additional APCT-3 measurements were performed at Site U1424 (Fig. F41). The bottom water temperature at this site was estimated to be $0.45^{\circ} \mathrm{C}$, based on the average mudline temperature. The lowest temperature measured at the mudline was $0.22^{\circ} \mathrm{C}$ and was in good agreement with temperatures measured at Sites U1422 and U1423.

At Site 794, the measured geothermal gradient was $125^{\circ} \mathrm{C} / \mathrm{km}$ (Shipboard Scientific Party, 1990) and the estimated heat flow ranged between 103 (Shipboard Scientific Party, 1990) and $105 \mathrm{~mW} / \mathrm{m}^{2}$ (Langseth and Tamaki, 1992). Heat flow has been reestimated following the method proposed by Pribnow et al. 
(2000) (Fig. F41). In order to assess the possible impact of thermal conductivity measurements on heat flow estimates, this estimation has been done using two distinct sets of thermal conductivity data (Leg 127 Site 794 and Expedition 346 Site U1424; see "Physical properties") and a geothermal gradient of $125^{\circ} \mathrm{C} / \mathrm{km}$. The calculated heat flows were 106 and $107 \mathrm{~mW} / \mathrm{m}^{2}$, respectively, and were in good agreement with previous calculations at this site.

\section{Stratigraphic correlation and sedimentation rates}

A composite section and splice (as defined in "Stratigraphic correlation and sedimentation rates" in the "Methods" chapter [Tada et al., 2015b]) were constructed for Site U1424 to establish a continuous sediment sequence utilizing Holes U1424A-U1424C, which were cored to $158.8,154.7$, and $63.9 \mathrm{~m}$ CSF-A, respectively. Because Cores 346-U1424C-1H through $3 \mathrm{H}$ were dedicated to OSL dating, no onboard measurements were conducted. Only Cores 346-U1424C$4 \mathrm{H}$ through $7 \mathrm{H}$ were subject to stratigraphic correlation. Splicing among all holes enabled us to construct a continuous stratigraphic sequence for the entire drilled interval.

\section{Construction of CCSF-A scale Definition of top (0 $\mathrm{m}$ CCSF-A)}

Holes U1424A and U1424B both recovered the mudline. We selected the longer Core $346-\mathrm{U} 1424 \mathrm{~A}-1 \mathrm{H}$ as the anchor core and defined the top as $0 \mathrm{~m}$ CCSF-A (as defined in "Stratigraphic correlation and sedimentation rates" in the "Methods" chapter [Tada et al., 2015b]).

\section{Compositing of cores}

The CCSF-A scale for Site U1424 is based on correlation of magnetic susceptibility and GRA density data from the WRMSL and the Special Task Multisensor Logger, as well as RGB blue (B) data extracted from images acquired by the Section Half Imaging Logger (see "Physical properties" in the "Methods" chapter [Tada et al., 2015b] for details). Magnetic susceptibility and GRA density were measured at 2.5 and $5 \mathrm{~cm}$ intervals for Holes U1424A and U1424B, respectively, whereas B was calculated at $0.5 \mathrm{~cm}$ intervals. Correlative horizons are most easily identified in the magnetic susceptibility and B data. Extremely fine scale correlations are best achieved using the $0.5 \mathrm{~cm}$ B data.

For the interval between $\sim 125$ and $\sim 150$ m CSF-A, including Cores 346-U1424A-15H and $16 \mathrm{H}$ and 346$\mathrm{U} 1424 \mathrm{~B}-15 \mathrm{H}$ and $16 \mathrm{H}$, physical properties such as magnetic susceptibility, GRA density, and B data show no definitive correlative patterns. Thus, we visually identified unique lithologic features correlative between the holes. An ash layer found at Sections 346-U1424A-15H-6, $65 \mathrm{~cm}$ (138.45 m CSF-A), and 346-U1424B-15H, $103 \mathrm{~cm}$ (133.23 m CSF-A), were judged to be identical based on their common white color, sharp base, gradational upward with thickness of 3-5 cm, and association with a thin ash layer $\sim 30 \mathrm{~cm}$ shallower (Fig. F42A). The size and shape of volcanic glass particles are similar between the two ashes. Thus, this ash layer is composited to 142.7 m CCSF-A.

Dispersed ash in mottled diatomaceous mud shown in Figure F42B was commonly found at Sections 346-U1424A-15H-6, $110 \mathrm{~cm}$ (138.9 m CSF-A), and 346-U1424B-16H-1， 35 cm (136.05 m CSF-A). Though this feature is not unique and further sedimentological examination is necessary, this horizon is composited to $143.2 \mathrm{~m}$ CCSF-A for Holes U1424A and U1424B.

In order to tie Core 346-U1424A-16H to Core 346U1424B-16H, we matched an ash layer (Fig. F42C) at Sections 346-U1424A-16H-1, 99 cm (140.71 m CSF-A), and 346-U1424B-16H-5, 28 cm (141.98 m CSF-A). This dark gray ash layer has a sharp base grading upward for $\sim 3 \mathrm{~cm}$ above the base. This feature is composited to $149 \mathrm{~m}$ CCSF-A in both holes.

Cores $346-\mathrm{U} 1424 \mathrm{C}-4 \mathrm{H}$ through $7 \mathrm{H}$ are tied to cores from Holes U1424A and U1424B using the B data (Fig. F43A, F43B). The vertical offsets used to create the CCSF-A scale are tabulated in Table T17. The correlative features discussed above yield reasonable alignment of the cores. However, it implies an $\sim 4 \mathrm{~m}$ large coring gap between Cores 346-U1424B-1H and 2H (Fig. F43A) and between Cores 346-U1424A-15H and $16 \mathrm{H}$ (Fig. F43C). An apparent $\sim 2 \mathrm{~m}$ overlap is also implied at the bottom of Core 346-U1424A-14H relative to the top of $15 \mathrm{H}$ and at the bottom of Core $346-\mathrm{U} 1424 \mathrm{~B}-15 \mathrm{H}$ relative to the top of $16 \mathrm{H}$ (Fig. F43C). These overlaps might be due to stretching of sediment during APC coring, which is consistent with a vertical linear disturbance observed in the upper $1 \mathrm{~m}$ of Section 346-U1424A-15H-5.

\section{Construction of CCSF-D scale}

The combination of Holes U1424A and U1424B covers the complete stratigraphic section to $158.87 \mathrm{~m}$ CSF-A (167.75 m CCSF-A). We constructed a splice, avoiding whole-round sampling intervals and minimizing inclusion of disturbed intervals as much as possible. Selected splice intervals are listed in Table T18. Data sets used to choose correlative features are identified in the last column. 


\section{Sedimentation rates}

All age control datums, including biostratigraphic markers, paleomagnetic events, and tentatively dated tephra from Holes U1424A-U1424C, were plotted on Figure F44A and listed in Table T19. Depth-age fits determined using only paleomagnetic datums fall within the upper and lower limits defined by the $\mathrm{FO}$ and $\mathrm{LO}$ of biostratigraphic markers, except for the interval between 115 and $144 \mathrm{~m}$ CCSF-A. In this interval, the FO of $N$. koizumii strongly constrains the upper limit of the depth-age line and we set it as an inflection point, which yields the slow sedimentation rate between 137.87 and $143.55 \mathrm{~m}$ CCSF-A. This apparent slow sedimentation rate could be due to a hiatus as suggested by a clear shift in physical properties at around this interval (see "Physical properties"). Relatively large depth uncertainty in the identification of the Cochiti paleomagnetic event might be due to this slow sedimentation rate. The tentative identification ZnpOhta tephra at $142.86 \mathrm{~m} \mathrm{CCSF-A} \mathrm{(see} \mathrm{"Lithostratig-}$ raphy") also departs from the most likely depth-age relation probably due to this potential hiatus. The rapid decrease of $S$. arachnea group at $132.84 \mathrm{~m}$ CCSF-A is apparently an outlier, which may be due to the uncertainty in the age of this event (see "Biostratigraphy" in the "Methods" chapter [Tada et al., 2015b]). The resulting ages of the lithologic Subunit IA/IB, Subunit IB/IIA, and Subunit IIA/IIB boundaries and the hole bottom are at 1.21, 2.14, 2.69, and 5.12 $\mathrm{Ma}$, respectively.

Sedimentation rates at Site U1424 range from 14.3 to $72.3 \mathrm{~m} / \mathrm{m} . \mathrm{y}$. and are lower in Subunit IB and the lower middle of Subunit IIB; moderate in the upper Subunit IA, Subunit IIA, and the upper and lower parts of Subunit IIB; and higher in the lower Subunit IA and the middle of Subunit IIB (Fig. F44B). The moderate to higher sedimentation rates are associated with lower GRA density, which suggests that the diatom flux was higher during these periods. Lower sedimentation rates in Subunit IB and the lower middle of Subunit IIB are associated with maxima in GRA density, which suggests a decrease in the diatom flux and relative increase of detrital fraction (see "Lithostratigraphy" and "Biostratigraphy").

\section{References}

Adkins, J.F., McIntyre, K., and Schrag, D.P., 2002. The salinity, temperature, and $\delta^{18} \mathrm{O}$ of the glacial deep ocean. Science, 298(5599):1769-1773. doi:10.1126/ science.1076252

Bender, M., Jahnke, R., Weiss, R., Martin, W., Heggie, D.T., Orchardo, J., and Sowers, T., 1989. Organic carbon oxidation and benthic nitrogen and silica dynamics in San
Clemente Basin, a continental borderland site. Geochim. Cosmochim. Acta, 53(3):685-697. doi:10.1016/00167037(89)90011-2

Blum, P., 1997. Physical properties handbook: a guide to the shipboard measurement of physical properties of deep-sea cores. ODP Tech. Note, 26. doi:10.2973/ odp.tn.26.1997

Brumsack, H.-J., and Zuleger, E., 1992. Boron and boron isotopes in pore waters from ODP Leg 127, Sea of Japan. Earth Planet. Sci. Lett., 113(3):427-433. doi:10.1016/ 0012-821X(92)90143-J

Brumsack, H.-J., Zuleger, E., Gohn, E., and Murray, R.W., 1992. Stable and radiogenic isotopes in pore waters from Leg 127, Japan Sea. In Pisciotto, K.A., Ingle, J.C., Jr., von Breymann, M.T., Barron, J., et al., Proc. ODP, Sci. Results, 127/128 (Pt. 1): College Station, TX (Ocean Drilling Program), 635-650. doi:10.2973/ odp.proc.sr.127128-1.165.1992

Dalsgaard, T., Thamdrup, B., and Canfield, D.E., 2005. Anaerobic ammonium oxidation (anammox) in the marine environment. Res. Microbiol., 156(4):457-464. doi:10.1016/j.resmic.2005.01.011

D'Hondt, S., Jørgensen, B.B., Miller, D.J., Batzke, A., Blake, R., Cragg, B.A., Cypionka, H., Dickens, G.R., Ferdelman, T., Hinrichs, K.-U., Holm, N.G., Mitterer, R., Spivack, A., Wang, G., Bekins, B., Engelen, B., Ford, K., Gettemy, G., Rutherford, S.D., Sass, H., Skilbeck, C.G., Aiello, I.W., Guerin, G., House, C.H., Inagaki, F., Meister, P., Naehr, T., Niitsuma, S., Parkes, R.J., Schippers, A., Smith, D.C., Teske, A., Wiegel, J., Naranjo Padillo, C., and Solis Acosta, J.L., 2004. Distributions of microbial activities in deep subseafloor sediments. Science, 306(5705):22162221. doi:10.1126/science.1101155

Dickens, G.R., Koelling, M., Smith, D.C., Schneiders, L., and the IODP Expedition 302 Scientists, 2007. Rhizon sampling of pore waters on scientific drilling expeditions: an example from the IODP Expedition 302, Arctic Coring Expedition (ACEX). Sci. Drill., 4:22-25. doi:10.2204/iodp.sd.4.08.2007

Expedition 318 Scientists, 2011. Site U1359. In Escutia, C., Brinkhuis, H., Klaus, A., and the Expedition 318 Scientists, Proc. IODP, 318: Tokyo (Integrated Ocean Drilling Program Management International, Inc.). doi:10.2204/iodp.proc.318.107.2011

Föllmi, K.B., Cramp, A., Föllmi, K.E., Alexandrovich, J.M., Brunner, C., Burckle, L.H., Casey, M., deMenocal, P., Dunbar, R.B., Grimm, K.A., Holler, P., Ingle, J.C., Jr., Kheradyar, T., McEvoy, J., Nobes, D.C., Stein, R., Tada, R., von Breymann, M.T., and White, L.D., 1992. Darklight rhythms in the sediments of the Japan Sea: preliminary results from Site 798, with some additional results from Sites 797 and 799. In Pisciotto, K.A., Ingle, J.C., Jr., von Breymann, M.T., Barron, J., et al., Proc. ODP, Sci. Results, 127/128 (Pt. 1): College Station, TX (Ocean Drilling Program), 559-576. doi:10.2973/ odp.proc.sr.127128-1.159.1992

Froelich, P.N., Klinkhammer, G.P., Bender, M.L., Luedtke, N.A., Heath, G.R., Cullen, D., Dauphin, P., Hammond, D., Hartman, B., and Maynard, V., 1979. Early oxidation of organic matter in pelagic sediments of the eastern 
equatorial Atlantic: suboxic diagenesis. Geochim. Cosmochim. Acta, 43(7):1075-1090. doi:10.1016/00167037(79)90095-4

Griffith, E.M., and Paytan, A., 2012. Barite in the oceanoccurrence, geochemistry and paleoceanographic applications. Sedimentology, 59(6):1817-1835. doi:10.1111/ j.1365-3091.2012.01327.x

Hanai, T., Ikeya, N., and Yajima, M., 1980. Deep-sea Ostracoda from Deep Sea Drilling Project Site 435, Japan Trench. In Scientific Party, Init. Repts. DSDP, 56/57 (Pt. 2): Washington (U.S. Govt. Printing Office), 907909. doi:10.2973/dsdp.proc.5657.130.1980

Kopp, R.E., and Kirschvink, J.L., 2008. The identification and biogeochemical interpretation of fossil magnetotactic bacteria. Earth-Sci. Rev., 86(1-4):42-61. doi:10.1016/ j.earscirev.2007.08.001

Kucera, M., and Kennett, J.P., 2000. Biochronology and evolutionary implications of late Neogene California margin planktonic foraminiferal events. Mar. Micropaleontol., 40(1-2):67-81. doi:10.1016/ S0377-8398(00)00029-3

Langseth, M.G., and Tamaki, K., 1992. Geothermal measurements: thermal evolution of the Japan Sea basins and sediments. In Tamaki, K., Suyehiro, K., Allan, J., McWilliams, M., et al., Proc. ODP, Sci. Results, 127/128 (Pt. 2): College Station, TX (Ocean Drilling Program), 1297-1309. doi:10.2973/odp.proc.sr.1271282.227.1992

Middelburg, J.J., de Lange, G.J., and van der Weijden, C.H., 1987. Manganese solubility control in marine pore waters. Geochim. Cosmochim. Acta, 51(3):759-763. doi:10.1016/0016-7037(87)90086-X

Miwa, M., 2014. Foraminifera. In Sekiyu Kogyo Binran (Petroleum Technology Handbook) 2013: Tokyo (Jpn. Assoc. Pet. Technol.), 223-227. (in Japanese)

Murray, R.W., Brumsack, H.J., von Breymann, M.T., Sturz, A.A., Dunbar, R.B., and Gieskes, J.M., 1992. Diagenetic reactions in deeply buried sediments of the Japan Sea: a synthesis of interstitial-water chemistry results from Legs 127 and 128. In Tamaki, K., Suyehiro, K., Allan, J., McWilliams, M., et al., Proc. ODP, Sci. Results, 127/128 (Pt. 2): College Station, TX (Ocean Drilling Program), 1261-1274. doi:10.2973/odp.proc.sr.1271282.177.1992

Pribnow, D., Kinoshita, M., and Stein, C., 2000. Thermal Data Collection and Heat Flow Recalculations for Ocean Drilling Program Legs 101-180: Hanover, Germany (Inst. Joint Geosci. Res., Inst. Geowiss. Gemeinschaftsauf. [GGA]). http://www-odp.tamu.edu/publications/ heatflow/ODPReprt.pdf

Rahman, A., 1992. Calcareous nannofossil biostratigraphy of Leg 127 in the Japan Sea. In Pisciotto, K.A., Ingle, J.C., Jr., von Breymann, M.T., Barron, J., et al., Proc. ODP, Sci. Results, 127/128 (Pt. 1): College Station, TX (Ocean Drilling Program), 171-186. doi:10.2973/ odp.proc.sr.127128-1.123.1992

Shipboard Scientific Party, 1990. Site 794. In Tamaki, K., Pisciotto, K., Allan, J., et al., Proc. ODP, Init. Repts., 127: College Station, TX (Ocean Drilling Program), 71-167. doi:10.2973/odp.proc.ir.127.104.1990
Tada, R., 1994. Paleoceanographic evolution of the Japan Sea. Palaeogeogr., Palaeoclimatol., Palaeoecol., 108(34):487-508. doi:10.1016/0031-0182(94)90248-8

Tada, R., and Iijima, A., 1983. Petrology and diagenetic changes of Neogene siliceous rocks in northern Japan. J. Sediment. Res., 53(3):911-930. doi:10.1306/212F82E72B24-11D7-8648000102C1865D

Tada, R., Irino, T., and Koizumi, I., 1999. Land-ocean linkages over orbital and millennial timescales recorded in late Quaternary sediments of the Japan Sea. Paleoceanography, 14(2):236-247. doi:10.1029/1998PA900016

Tada, R., Koizumi, I., Cramp, A., and Rahman, A., 1992. Correlation of dark and light layers, and the origin of their cyclicity in the Quaternary sediments from the Japan Sea. In Pisciotto, K.A., Ingle, J.C., Jr., von Breymann, M.T., Barron, J., et al., Proc. ODP, Sci. Results, 127/ 128 (Pt. 1): College Station, TX (Ocean Drilling Program), 577-601. doi:10.2973/odp.proc.sr.1271281.160.1992

Tada, R., Murray, R.W., Alvarez Zarikian, C.A., Anderson, W.T., Jr., Bassetti, M.-A., Brace, B.J., Clemens, S.C., da Costa Gurgel, M.H., Dickens, G.R., Dunlea, A.G., Gallagher, S.J., Giosan, L., Henderson, A.C.G., Holbourn, A.E., Ikehara, K., Irino, T., Itaki, T., Karasuda, A., Kinsley, C.W., Kubota, Y., Lee, G.S., Lee, K.E., Lofi, J., Lopes, C.I.C.D., Peterson, L.C., Saavedra-Pellitero, M., Sagawa, T., Singh, R.K., Sugisaki, S., Toucanne, S., Wan, S., Xuan, C., Zheng, H., and Ziegler, M., 2015a. Expedition 346 summary. In Tada, R., Murray, R.W., Alvarez Zarikian, C.A., and the Expedition 346 Scientists, Proc. IODP, 346: College Station, TX (Integrated Ocean Drilling Program). doi:10.2204/iodp.proc.346.101.2015

Tada, R., Murray, R.W., Alvarez Zarikian, C.A., Anderson, W.T., Jr, Bassetti, M.-A., Brace, B.J., Clemens, S.C., Dickens, G.R., Dunlea, A.G., Gallagher, S.J., Giosan, L., da Costa Gurgel, M.H., Henderson, A.C.G., Holbourn, A.E., Ikehara, K., Irino, T., Itaki, T., Karasuda, A., Kinsley, C.W., Kubota, Y., Lee, G.S., Lee, K.E., Lofi, J., Lopes, C.I.C.D., Peterson, L.C., Saavedra-Pellitero, M., Sagawa, T., Singh, R.K., Sugisaki, S., Toucanne, S., Wan, S., Xuan, C., Zheng, H., and Ziegler, M., 2015b. Methods. In Tada, R., Murray, R.W., Alvarez Zarikian, C.A., and the Expedition 346 Scientists, Proc. IODP, 346: College Station, TX (Integrated Ocean Drilling Program). doi:10.2204/ iodp.proc.346.102.2015

Tada, R., Murray, R.W., Alvarez Zarikian, C.A., Anderson, W.T., Jr., Bassetti, M.-A., Brace, B.J., Clemens, S.C., da Costa Gurgel, M.H., Dickens, G.R., Dunlea, A.G., Gallagher, S.J., Giosan, L., Henderson, A.C.G., Holbourn, A.E., Ikehara, K., Irino, T., Itaki, T., Karasuda, A., Kinsley, C.W., Kubota, Y., Lee, G.S., Lee, K.E., Lofi, J., Lopes, C.I.C.D., Peterson, L.C., Saavedra-Pellitero, M., Sagawa, T., Singh, R.K., Sugisaki, S., Toucanne, S., Wan, S., Xuan, C., Zheng, H., and Ziegler, M., 2015c. Site U1422. In Tada, R., Murray, R.W., Alvarez Zarikian, C.A., and the Expedition 346 Scientists, Proc. IODP, 346: College Station, TX (Integrated Ocean Drilling Program). doi:10.2204/iodp.proc.346.103.2015

Tada, R., Murray, R.W., Alvarez Zarikian, C.A., Anderson, W.T., Jr, Bassetti, M.-A., Brace, B.J., Clemens, S.C., Dick- 
ens, G.R., Dunlea, A.G., Gallagher, S.J., Giosan, L., da Costa Gurgel, M.H., Henderson, A.C.G., Holbourn, A.E., Ikehara, K., Irino, T., Itaki, T., Karasuda, A., Kinsley, C.W., Kubota, Y., Lee, G.S., Lee, K.E., Lofi, J., Lopes, C.I.C.D., Peterson, L.C., Saavedra-Pellitero, M., Sagawa, T., Singh, R.K., Sugisaki, S., Toucanne, S., Wan, S., Xuan, C., Zheng, H., and Ziegler, M., 2015d. Site U1423. In Tada, R., Murray, R.W., Alvarez Zarikian, C.A., and the Expedition 346 Scientists, Proc. IODP, 346: College Station, TX (Integrated Ocean Drilling Program). doi:10.2204/iodp.proc.346.104.2015

Tamaki, K., Pisciotto, K., Allan, J., et al., 1990. Proc. ODP, Init. Repts., 127: College Station, TX (Ocean Drilling Program). doi:10.2973/odp.proc.ir.127.1990
Tamaki, K., Suyehiro, K., Allan, J., Ingle, J.C., Jr., and Pisciotto, K.A., 1992. Tectonic synthesis and implications of Japan Sea ODP drilling. In Tamaki, K., Suyehiro, K., Allan, J., McWilliams, M., et al., Proc. ODP, Sci. Results, 127/128 (Pt. 2): College Station, TX (Ocean Drilling Program), 1333-1348. doi:10.2973/odp.proc.sr.1271282.240.1992

Xuan, C., and Channell, J.E.T., 2009. UPmag: MATLAB software for viewing and processing $U$ channel or other pass-through paleomagnetic data. Geochem., Geophys., Geosyst., 10(10):Q10Y07. doi:10.1029/2009GC002584

Publication: 28 March 2015

MS 346-105 
Figure F1. Bathymetric map of Expedition 346 sites (red circles) in the marginal sea surrounded by the Japanese Islands, the Korean Peninsula, and the Eurasian continent and the East China Sea. Sites previously drilled by the Deep Sea Drilling Project (DSDP) and Ocean Drilling Program (ODP) (white circles) are also shown. Also illustrated are surface current systems within and surrounding this marginal sea.

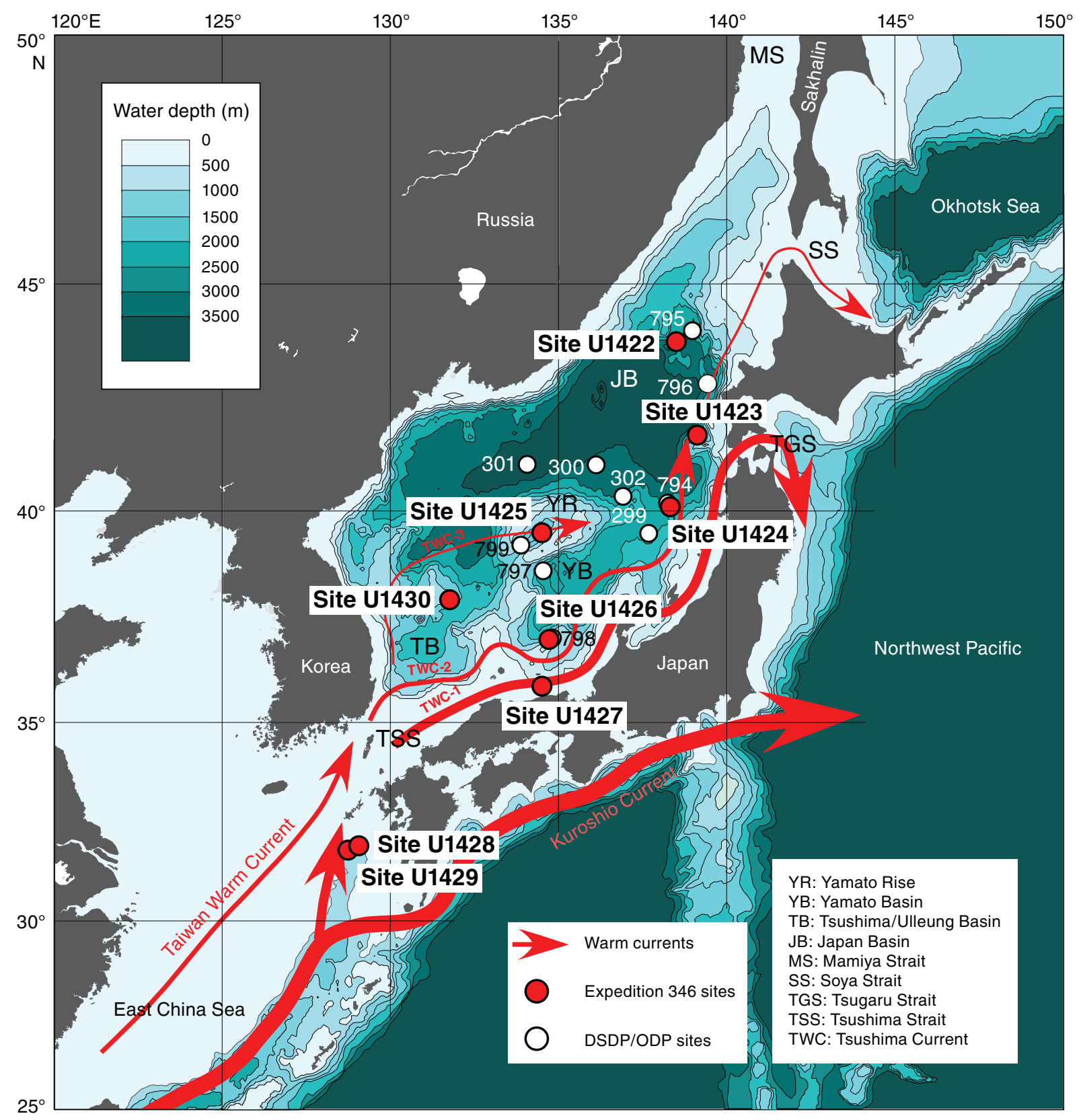


Figure F2. Lithologic summary, Hole U1424A. GRA = gamma ray attenuation.

Hole U1424A

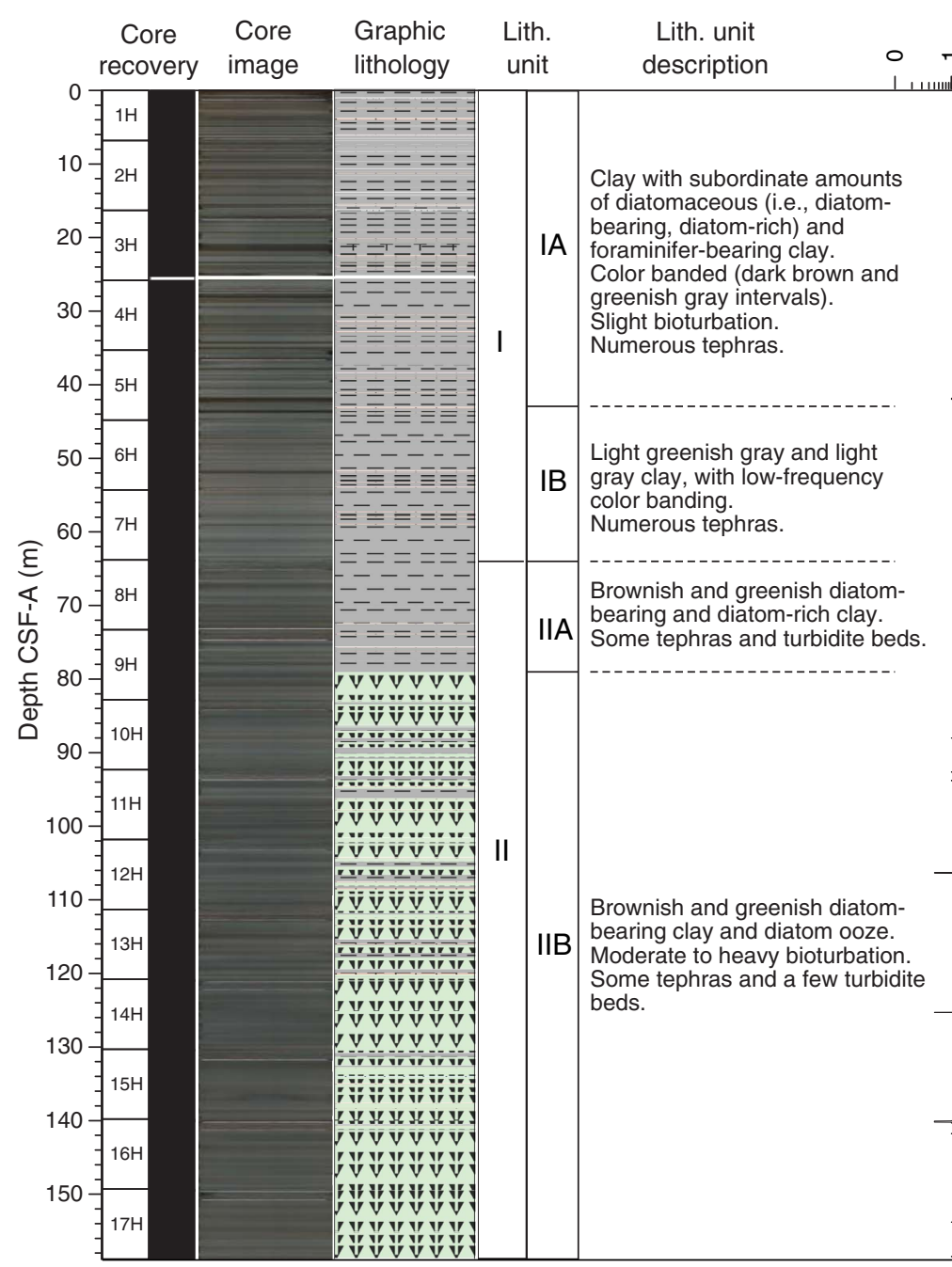

Magnetic

susceptibility

(SI)
GRA

bulk density

$\left(\mathrm{g} / \mathrm{cm}^{3}\right)$
Color reflectance $L^{*}$

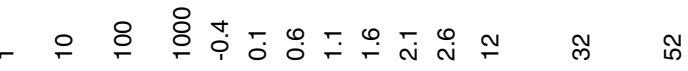

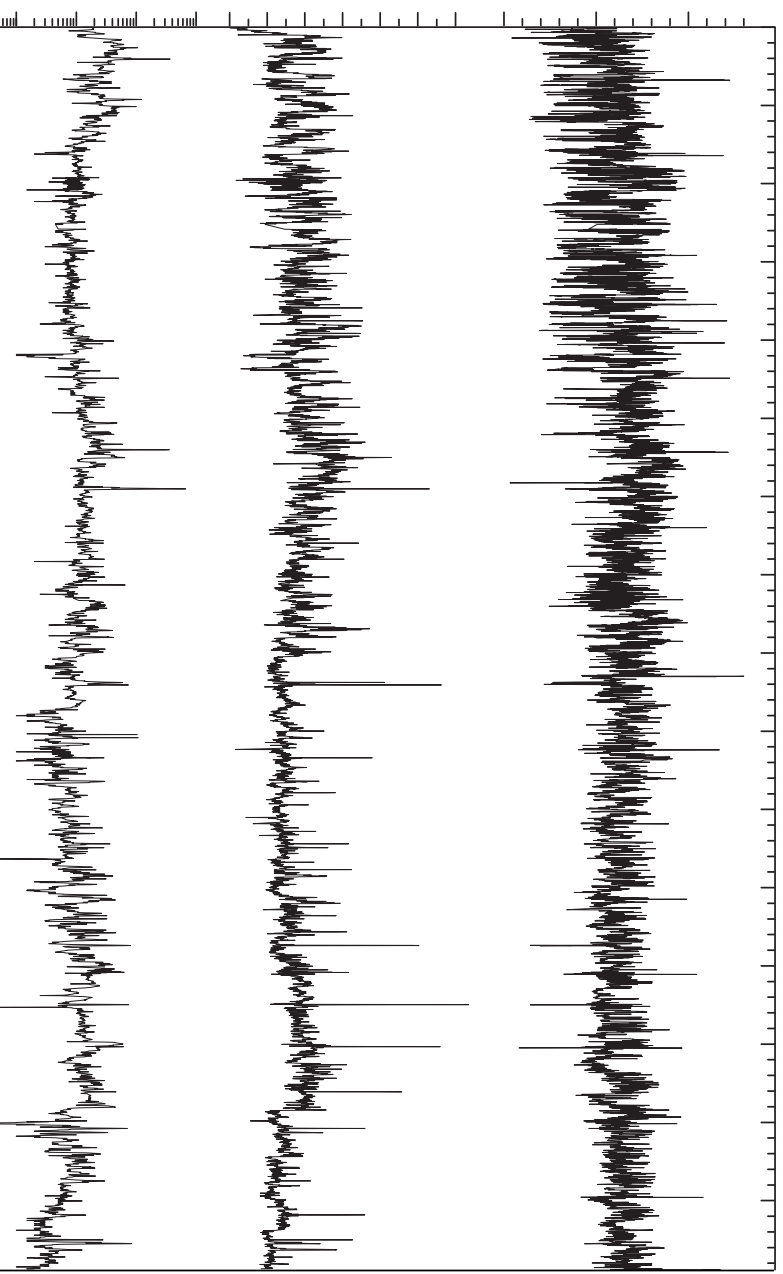


Figure F3. Lithologic summary, Hole U1424B. GRA = gamma ray attenuation.

Hole U1424B

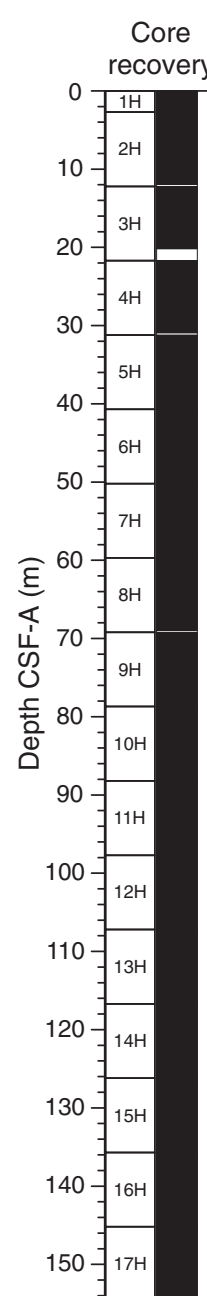

Magnetic

susceptibility

(SI)
GRA

bulk density $\left(\mathrm{g} / \mathrm{cm}^{3}\right)$
Color reflectance $L^{*}$

Core Graphic Lith. Lith. unit lithology unit description

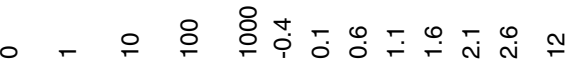
กิ กิ กิ

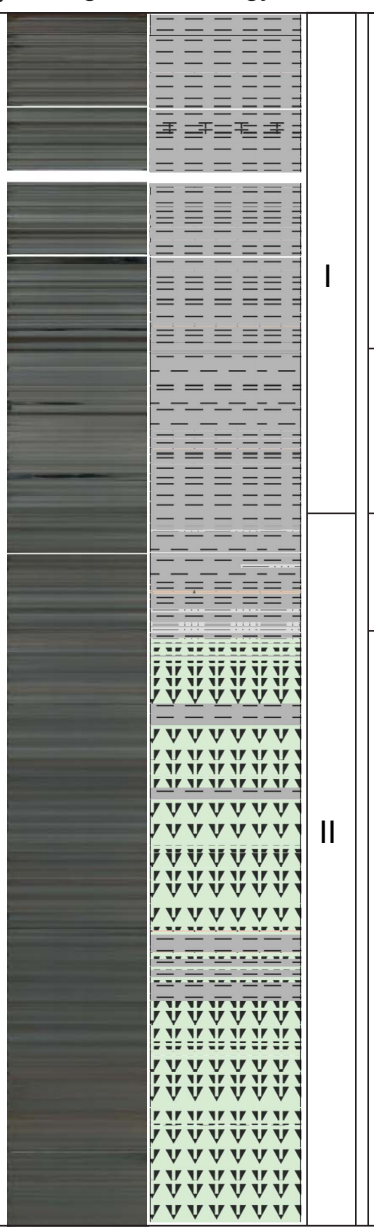

Clay with subordinate amounts of diatomaceous (i.e., diatom-

IA bearing, diatom-rich) and foraminifer-bearing clay.
Color banded (dark brown and greenish gray intervals). Slight bioturbation. Numerous tephras.

Light greenish gray and light

B gray clay, with low-frequency color banding. Numerous tephras.

Brownish and greenish diatom A bearing and diatom-rich clay.

A Some tephras and turbidite beds.

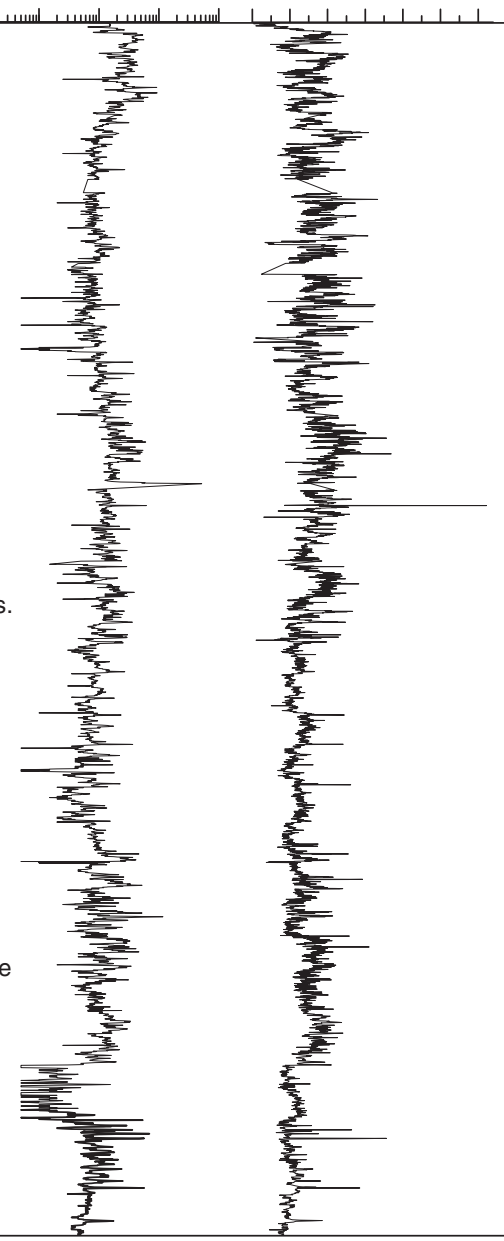

nnish and greenish diatom-

bearing clay and diatom ooze.

Moderate to heavy bioturbation. Some tephras and a few turbidite beds.

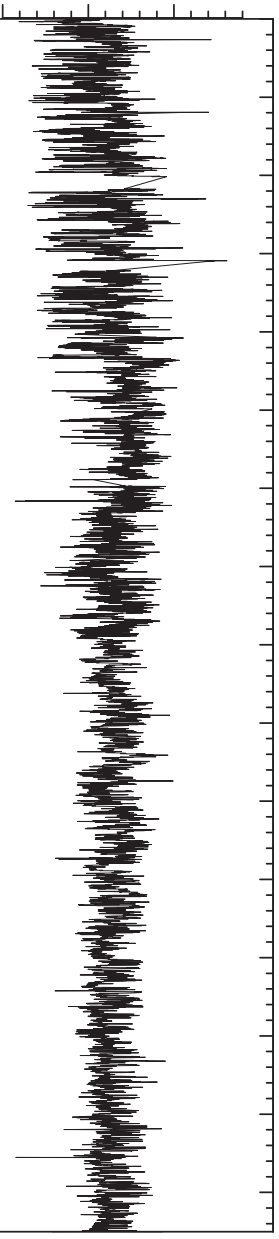


Figure F4. Lithologic summary, Hole U1424C. GRA = gamma ray attenuation.

Hole U1424C

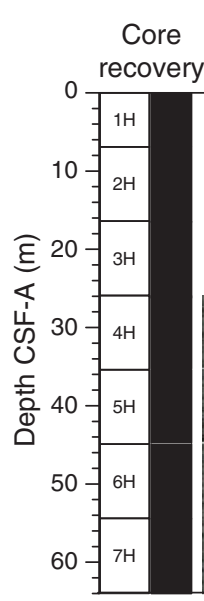

Magnetic

susceptibility

(SI)
GRA

bulk density Color reflectance
$L^{*}$

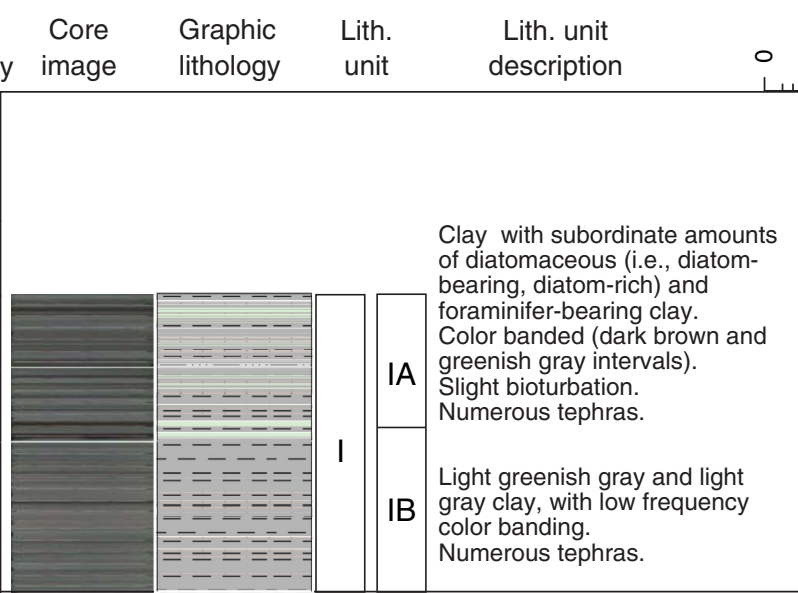
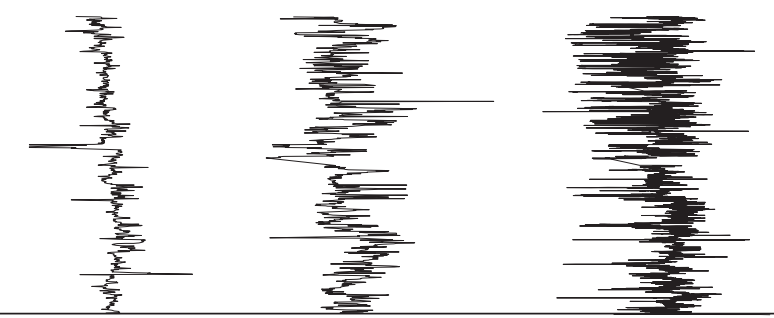
Figure F5. Hole-to-hole lithostratigraphic correlation, Site U1424. OSL = optically stimulated luminescence.

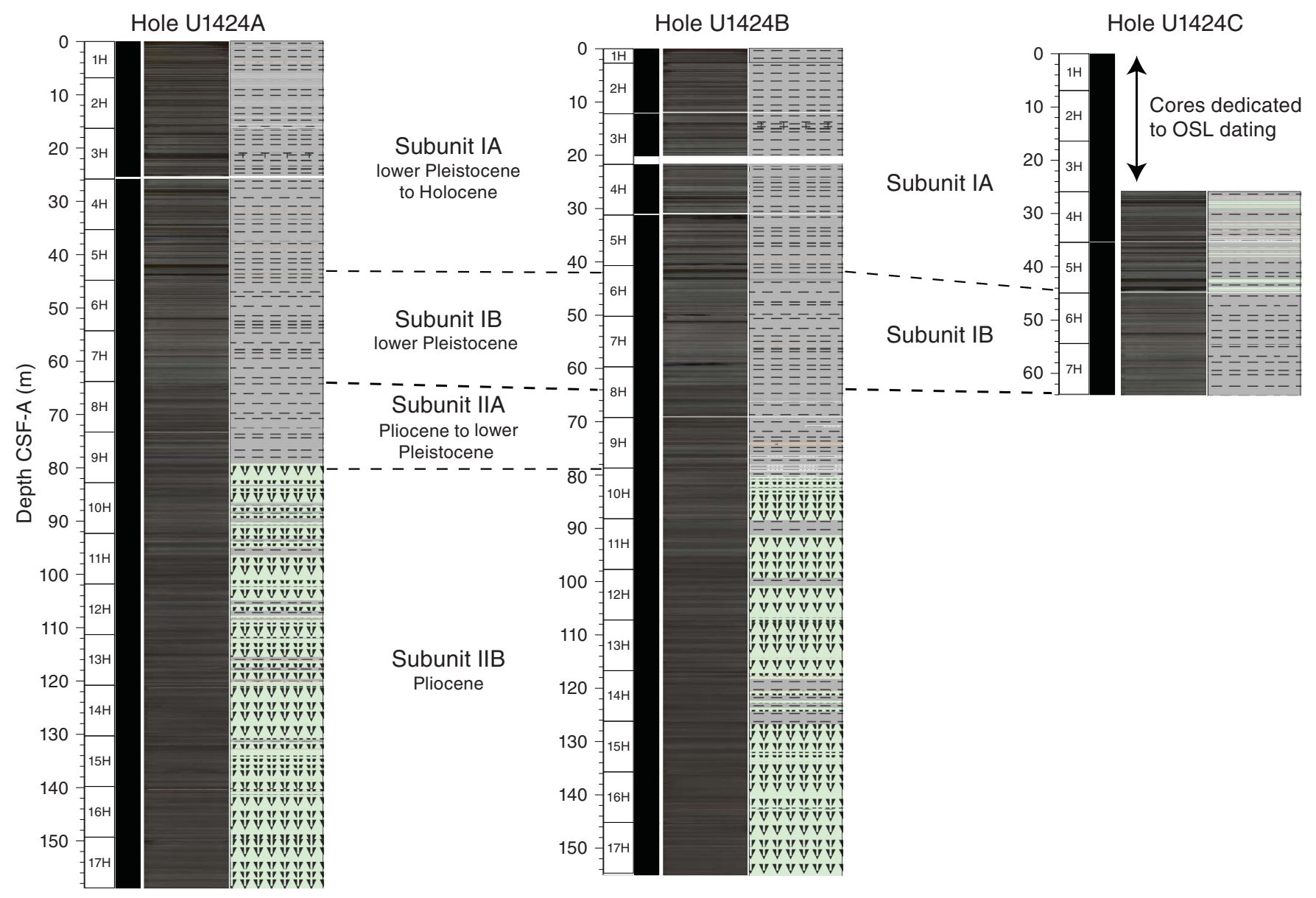


Figure F6. Distribution of tephra layers in Hole U1424A (number of tephra and total thickness in each core) and comparison with sediment lightness data $\left(\mathrm{L}^{*}\right)$.
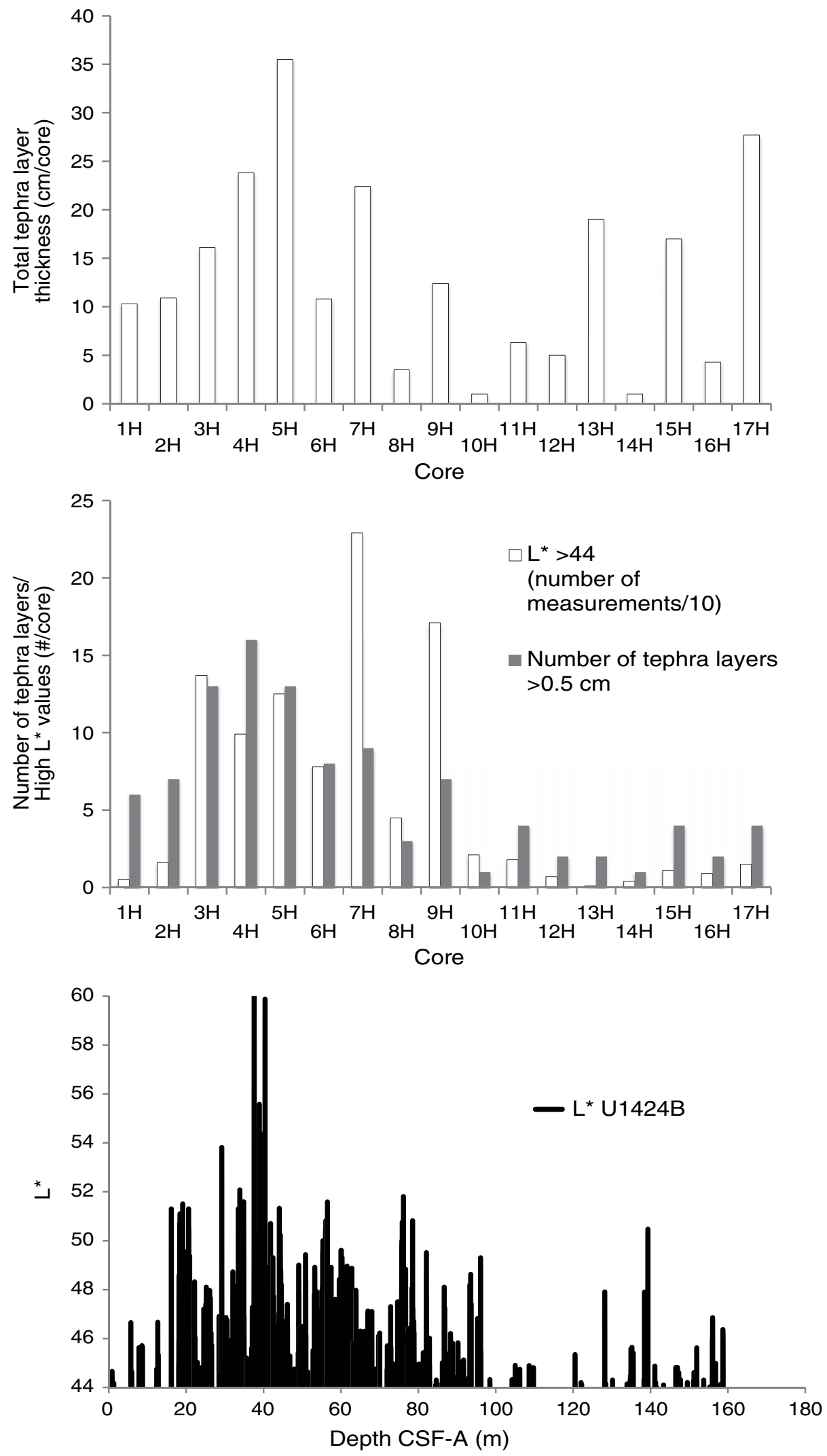
Figure F7. Variation of XRD peak intensity of identified minerals with depth, Hole U1424A.

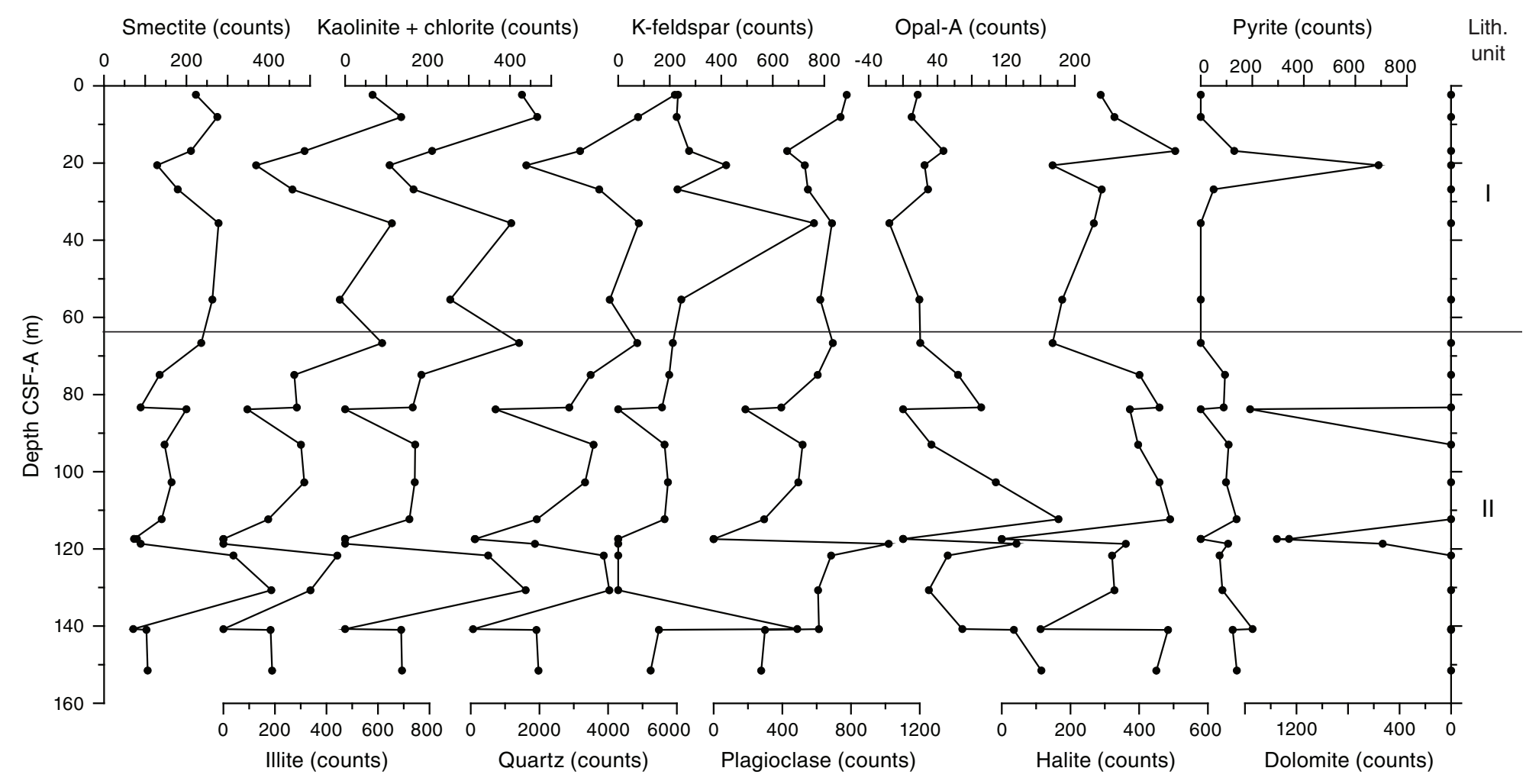


Hole U1424A

Subunit IA

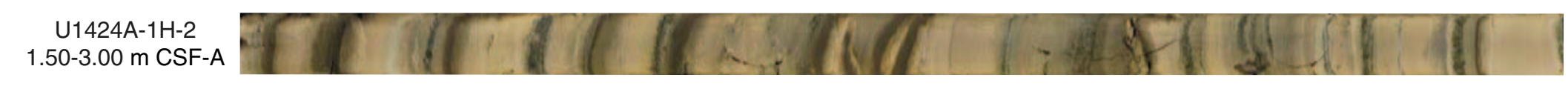

U1424A-2H-4 11.30-12.80 m CSF-A

\section{U1424A-3H-2}

17.80-19.30 m CSF-A

U1424A-5H-2 36.80-38.30 m CSF-A

U1424A-5H-5 41.30-42.80 m CSF-A
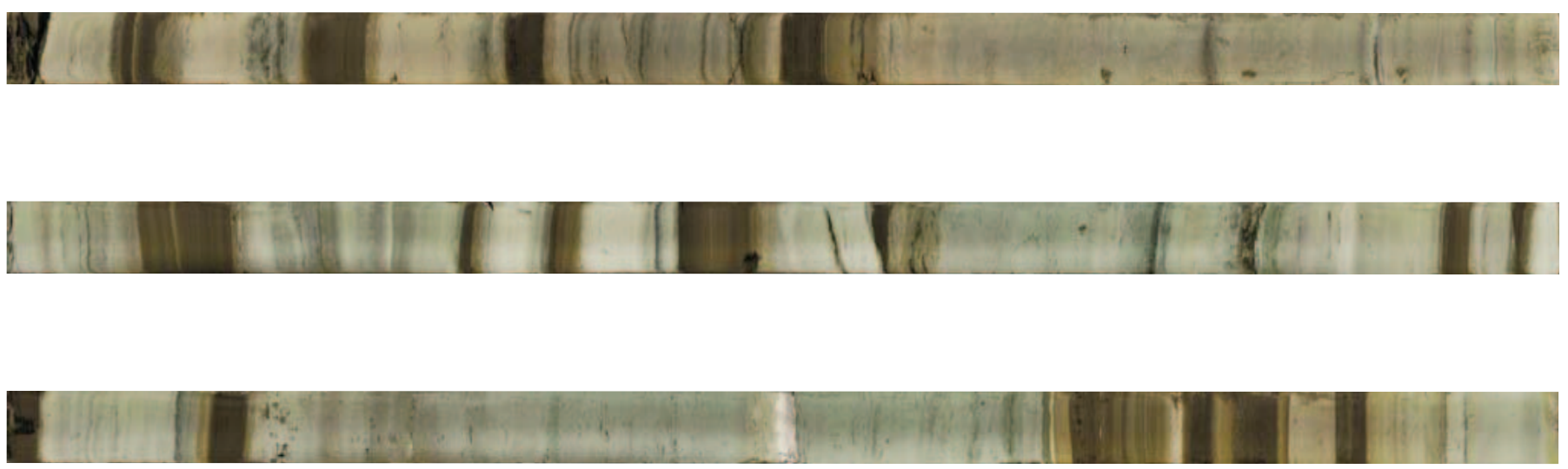
Figure F9. Detail of dark brown laminated intervals, Hole U1424A. Note enhanced color contrast to highlight sedimentary structures. Yellow bands = foraminifer-bearing layers.
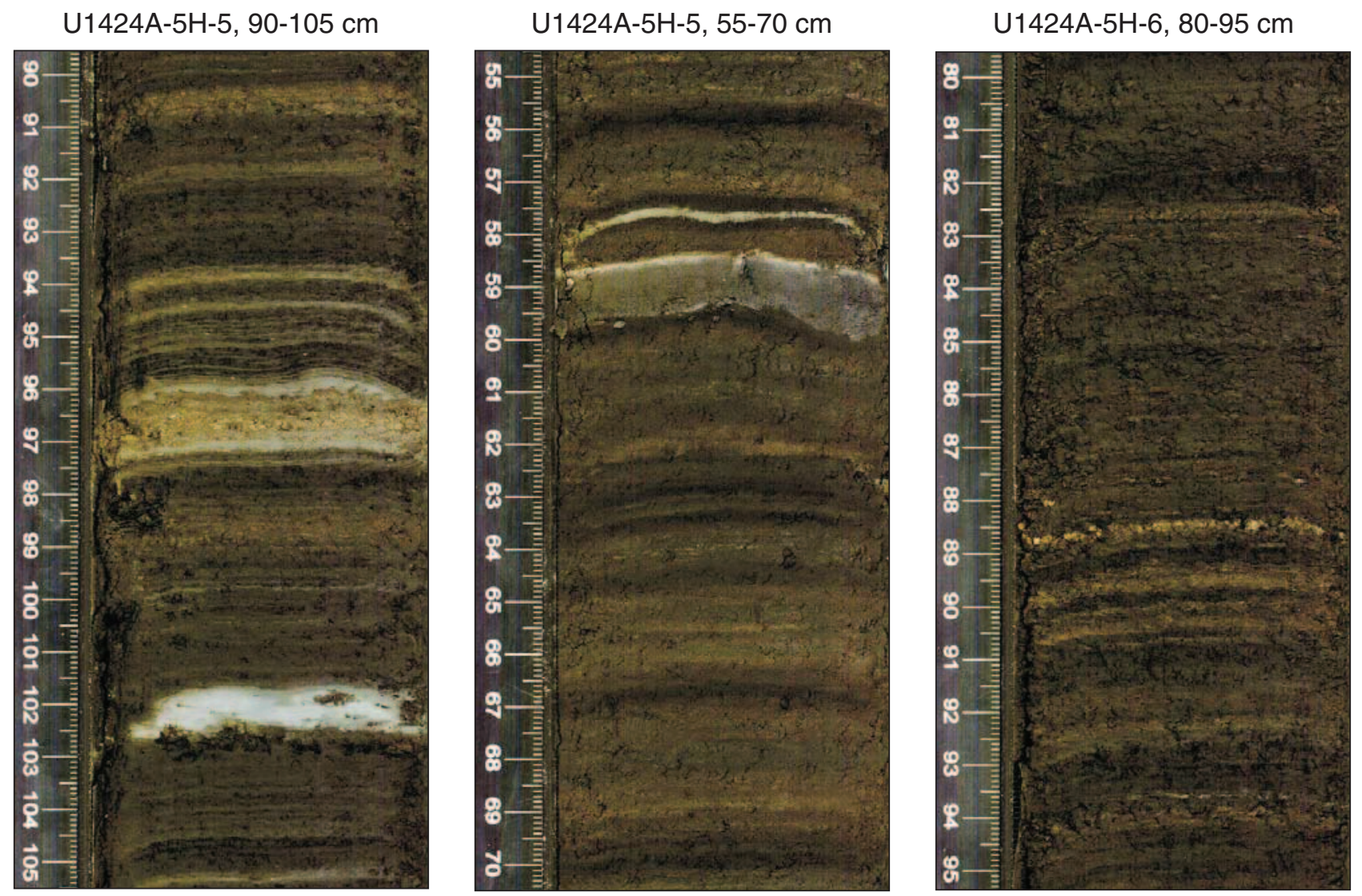
Figure F10. Detail of slightly bioturbated gray clay intervals intercalated between light greenish gray and nonbioturbated dark brown intervals, Hole U1424B. Note enhanced color contrast to highlight sedimentary structures.

U1424B-2H-3, 25-40 cm

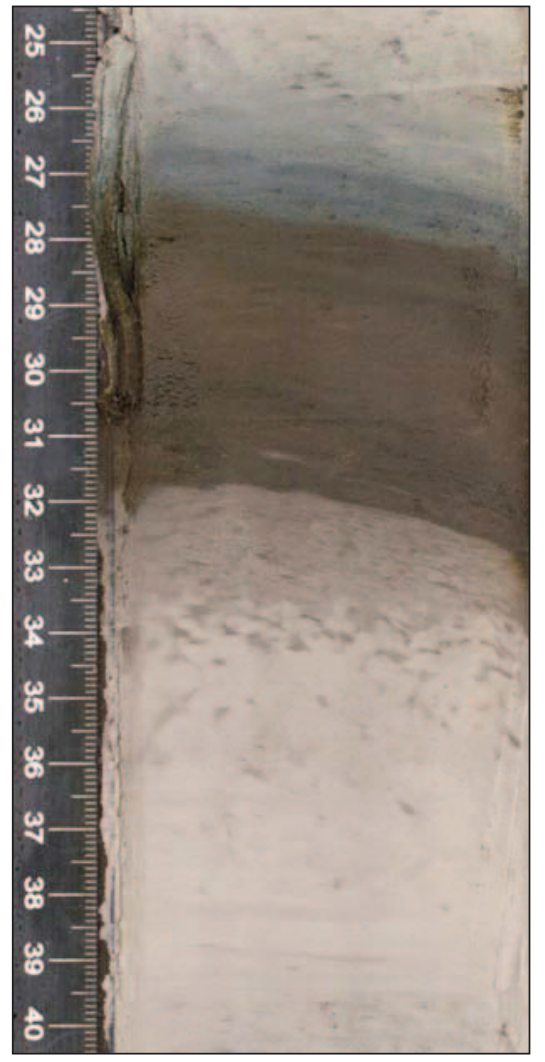

U1424B-2H-6, 5-20 cm

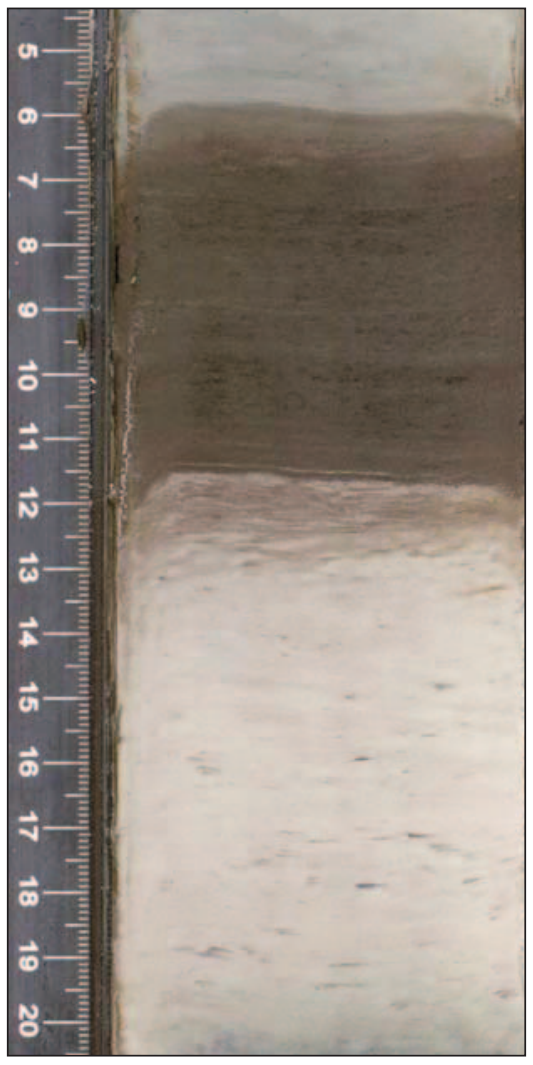

U1424B-3H-3, 26-41 cm

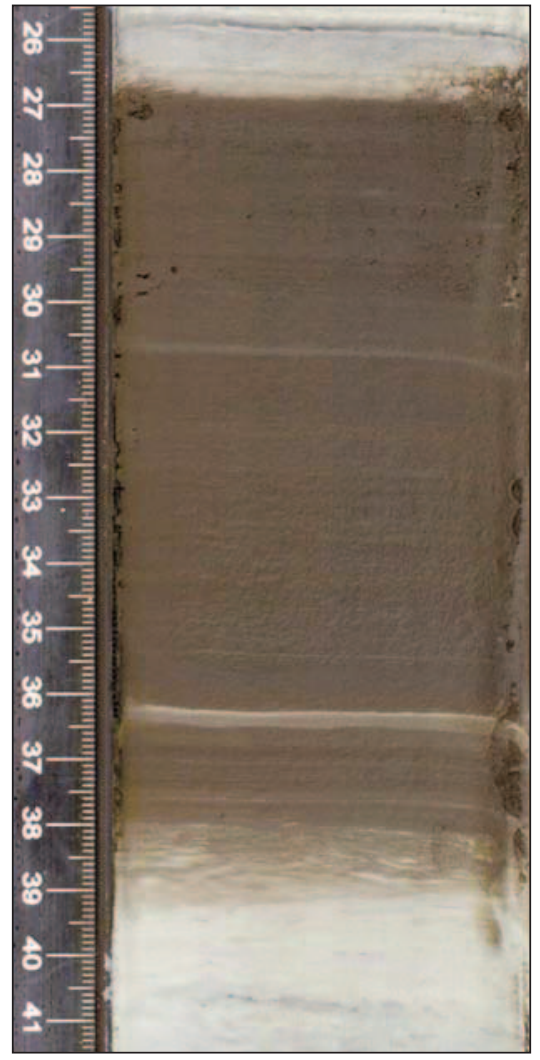


Figure F11. Details of euhedral pyrite crystals (Section 346-U1424C-4H-3, 78 cm).

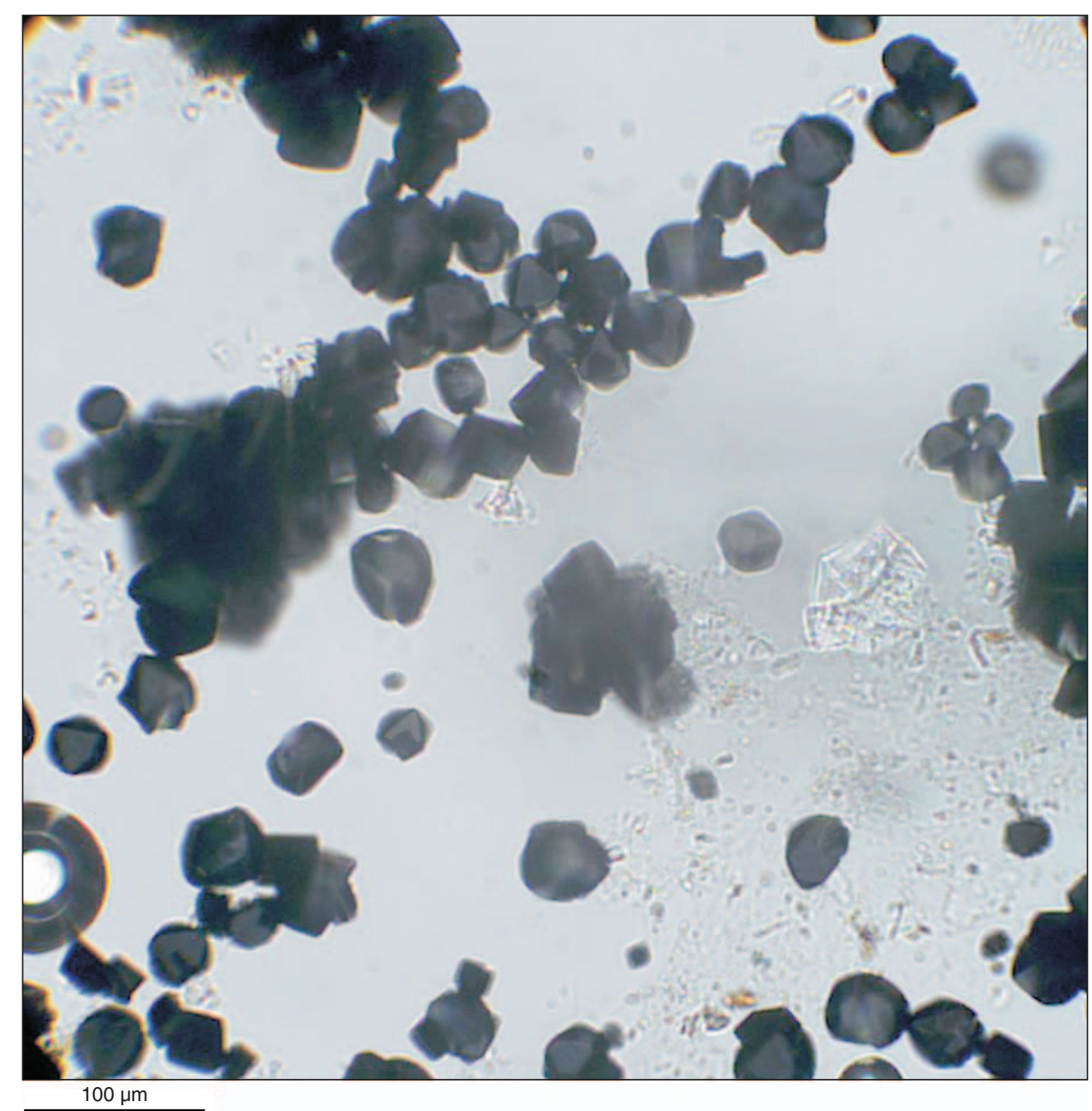


Figure F12. Photographs representative of Subunit IB, Hole U1424A. Note enhanced color contrast to highlight sedimentary structures.

Hole U1424A

Subunit IB

U1424A-6H-4 49.30-50.80 m CSF-A

U1424A-7H-1 54.30-55.80 m CSF-A

\section{U1424A-7H-2} 55.80-57.30 m CSF-A

\section{U1424A-7H-4} 58.80-60.30 m CSF-A

\section{U1424A-7H-6} 61.80-63.30 m CSF-A

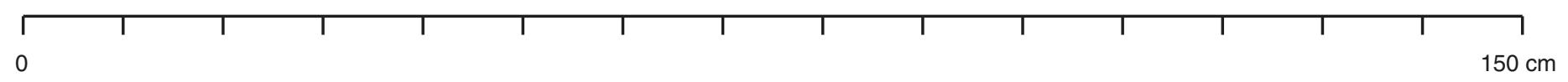


Figure F13. Details of fine-grained turbidite layers observed in Subunit IB and Unit II, Hole U1424A. T = turbidite. Note enhanced color contrast to highlight sedimentary structures.

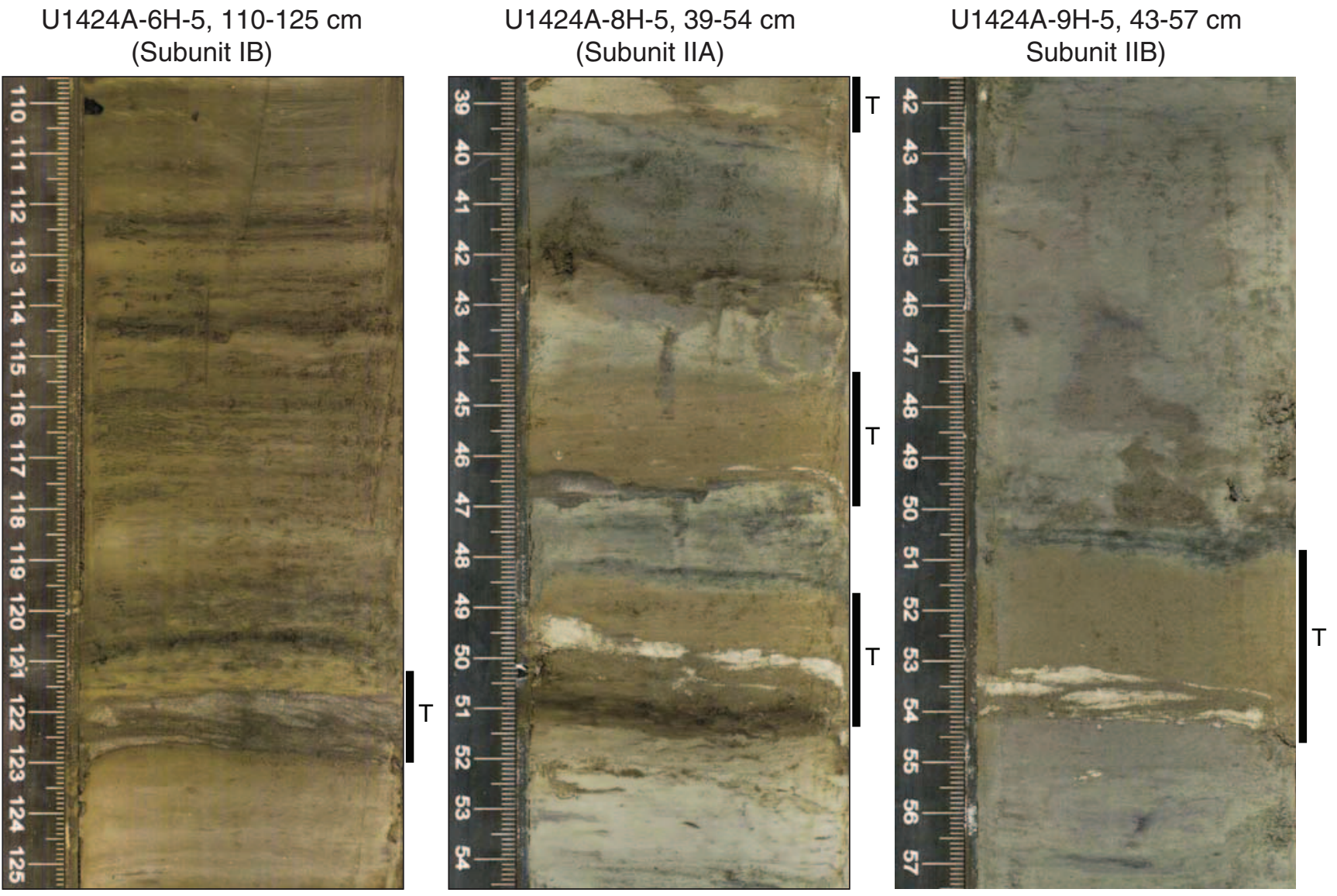


Figure F14. Photograph of dolomite nodule (interval 346-U1424A-13H-5, 18-27 cm).

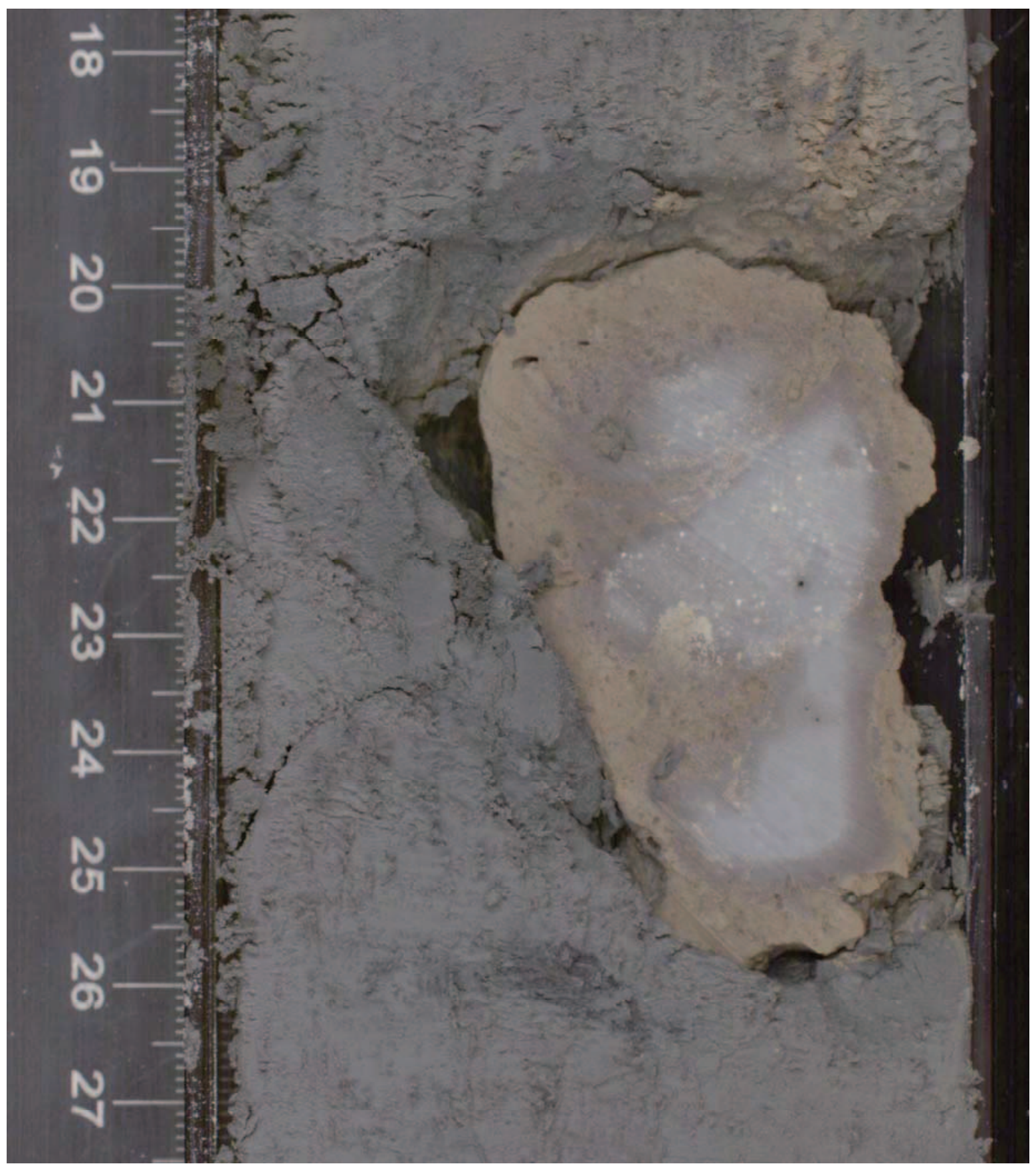


Figure F15. Details of dolomite crystals (Section 346-U1424A-13H-5, 20 cm).

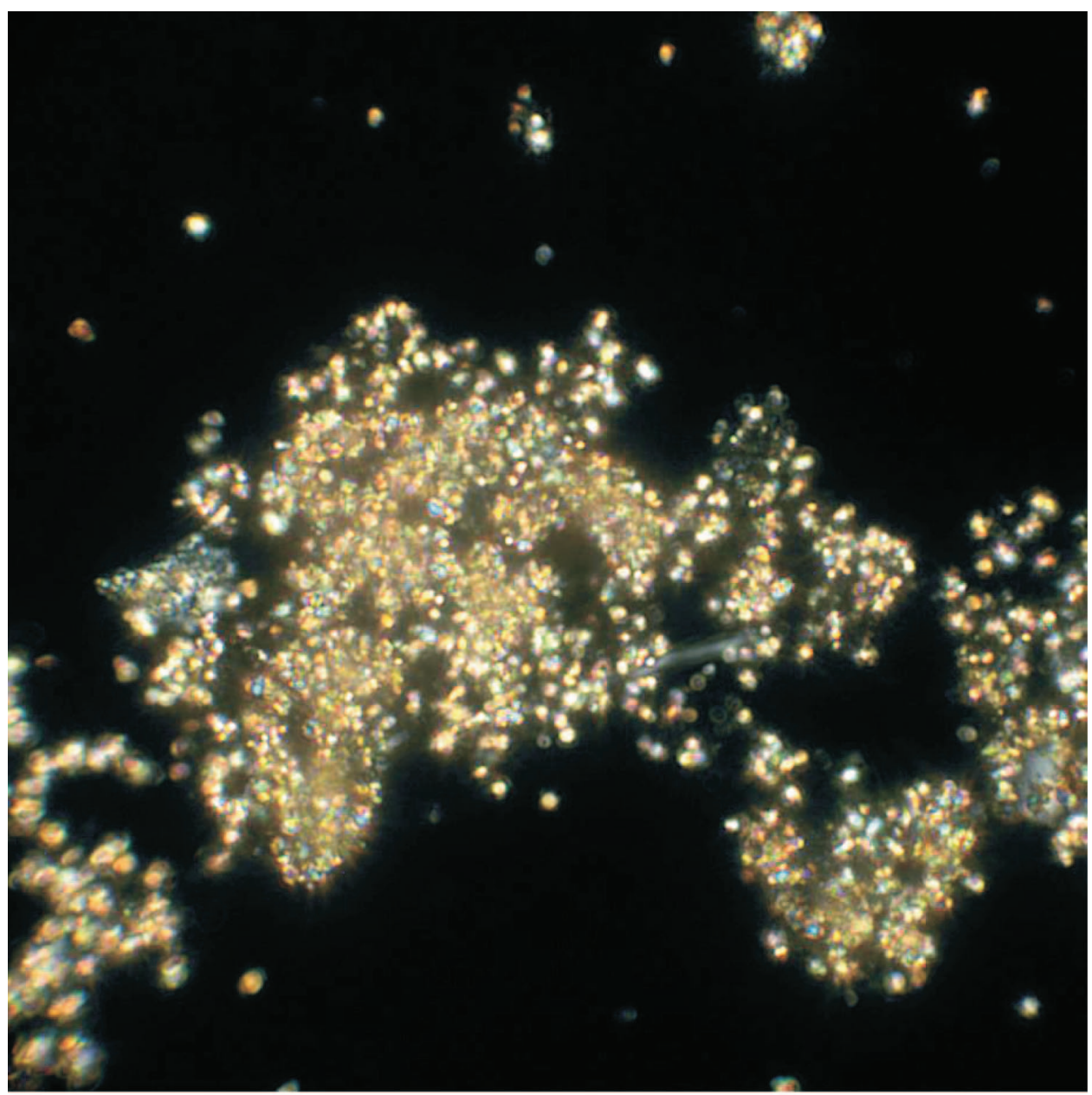


Figure F16. XRD diffractogram of a dolomite nodule (Sample 346-U1424A-13H-5, 23-24 cm).

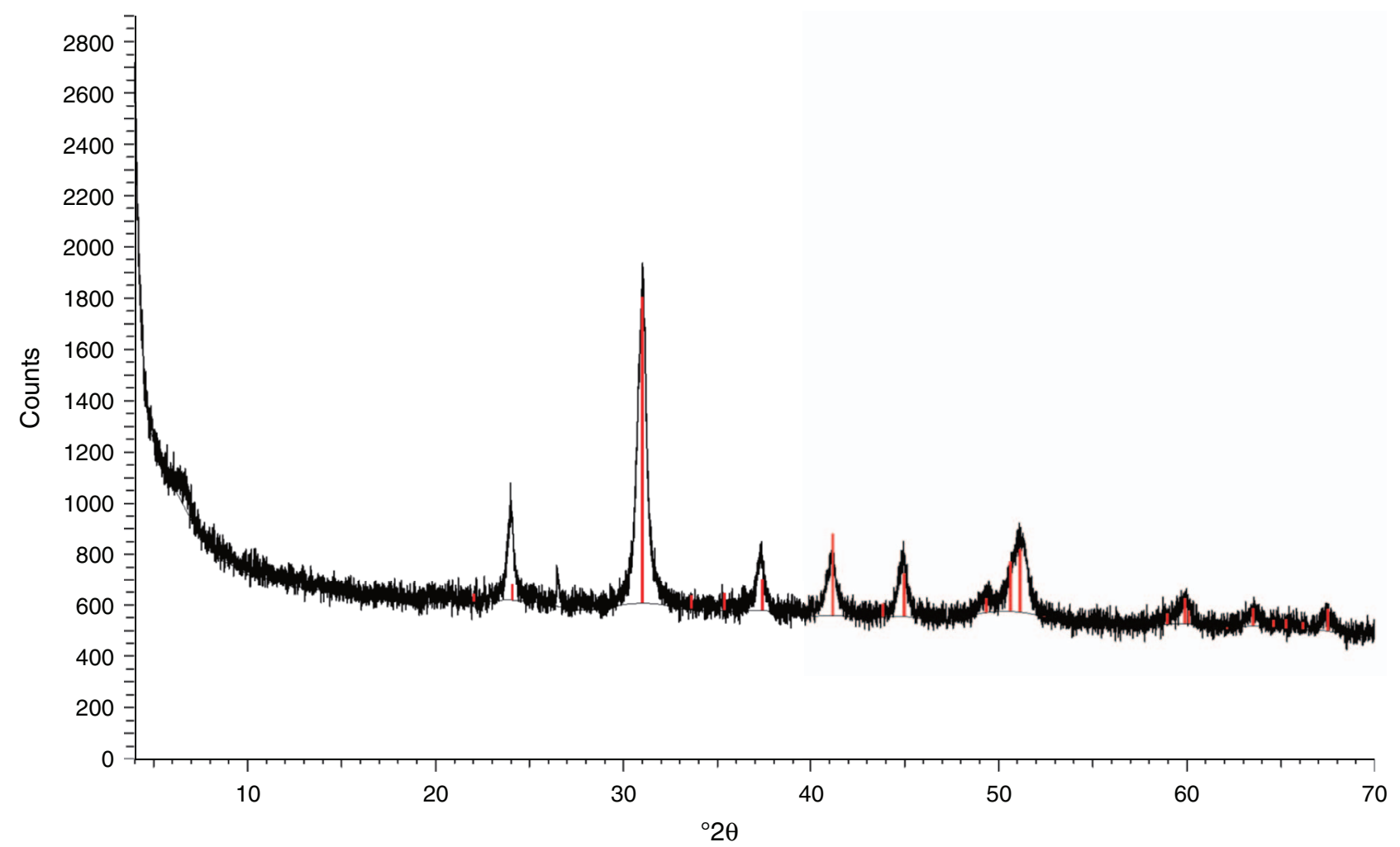

I Raw

I Dolomite 
Hole U1424A

Subunit IIA

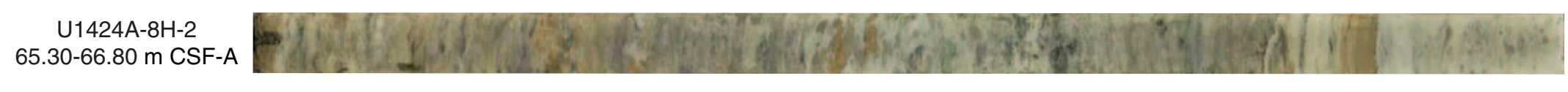

$\mathrm{U} 1424 \mathrm{~A}-8 \mathrm{H}-3$ 66.80-68.30 m CSF-A

\section{U1424A-8H-4} 68.30-69.80 m CSF-A

U1424A-8H-5 69.80-71.30 m CSF-A

U1424A-9H-1 73.30-74.80 m CSF-A

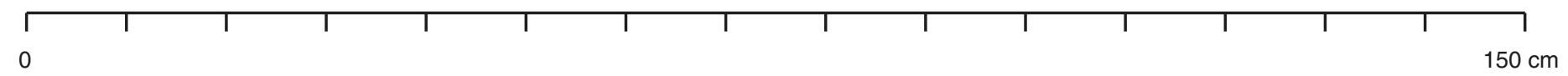


Figure F18. Photographs representative of Subunit IIB, Hole U1424A. Note enhanced color contrast to highlight sedimentary structures.

Hole U1424A

Subunit IIB

U1424A-9H-5
79. $30-80.80$ m CSF-A

U1424A-10H-4 87.30-88.80 m CSF-A

U1424A-12H-5 107.83-109.36 m CSF-A

U1424A-15H-6 137.80-139.30 m CSF-A

\section{U1424A-16H-1} 139.80-141.30 m CSF-A

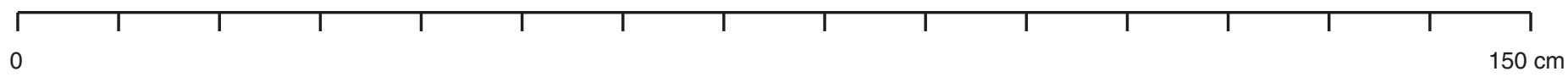


Figure F19. Example of a typical glauconite crystal (Section 346-U1424B-15H-2, 75 cm).

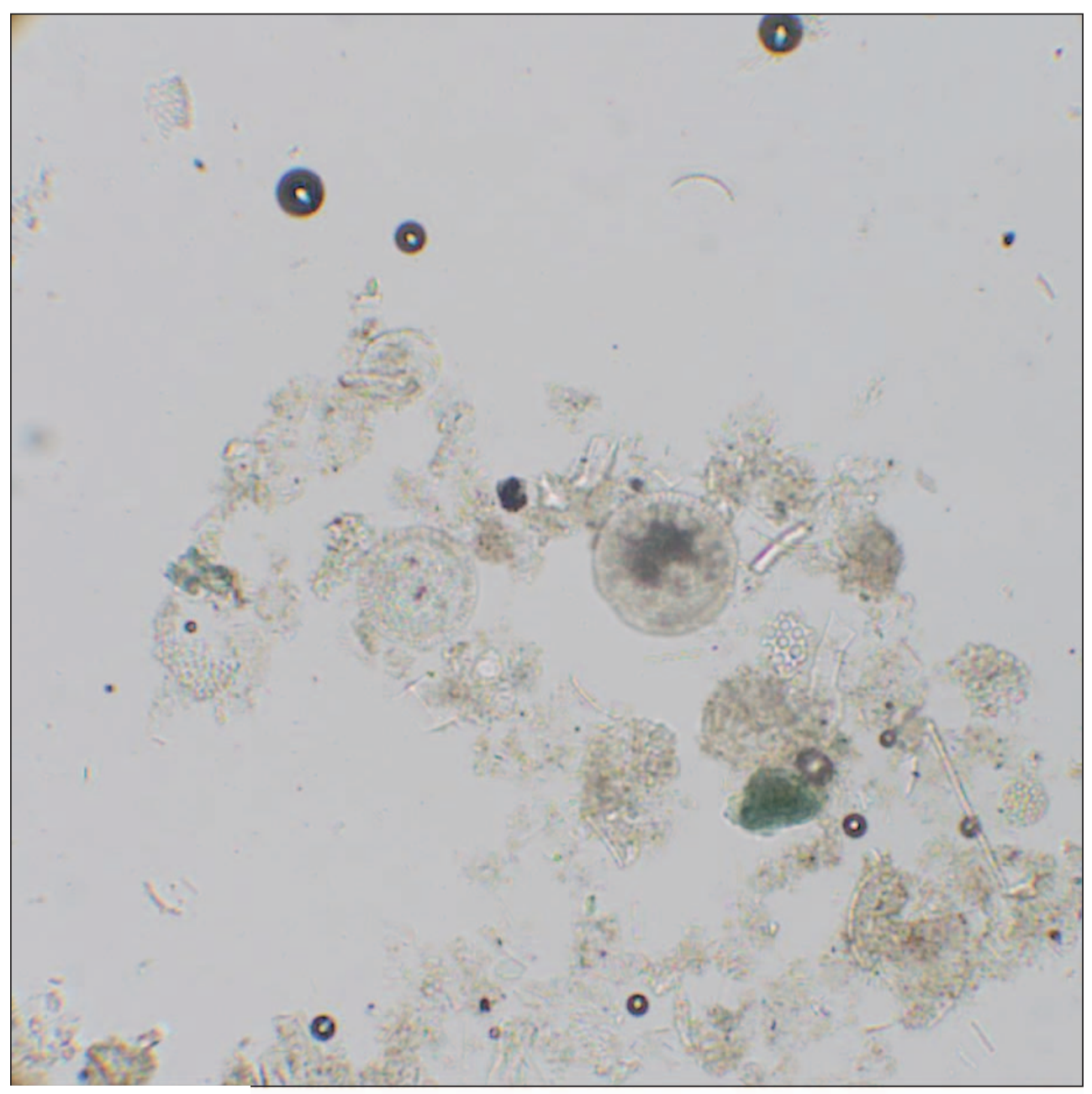

$100 \mu \mathrm{m}$ 
Figure F20. Integrated calcareous and siliceous microfossil biozonation, Site U1424.

Hole U1424A

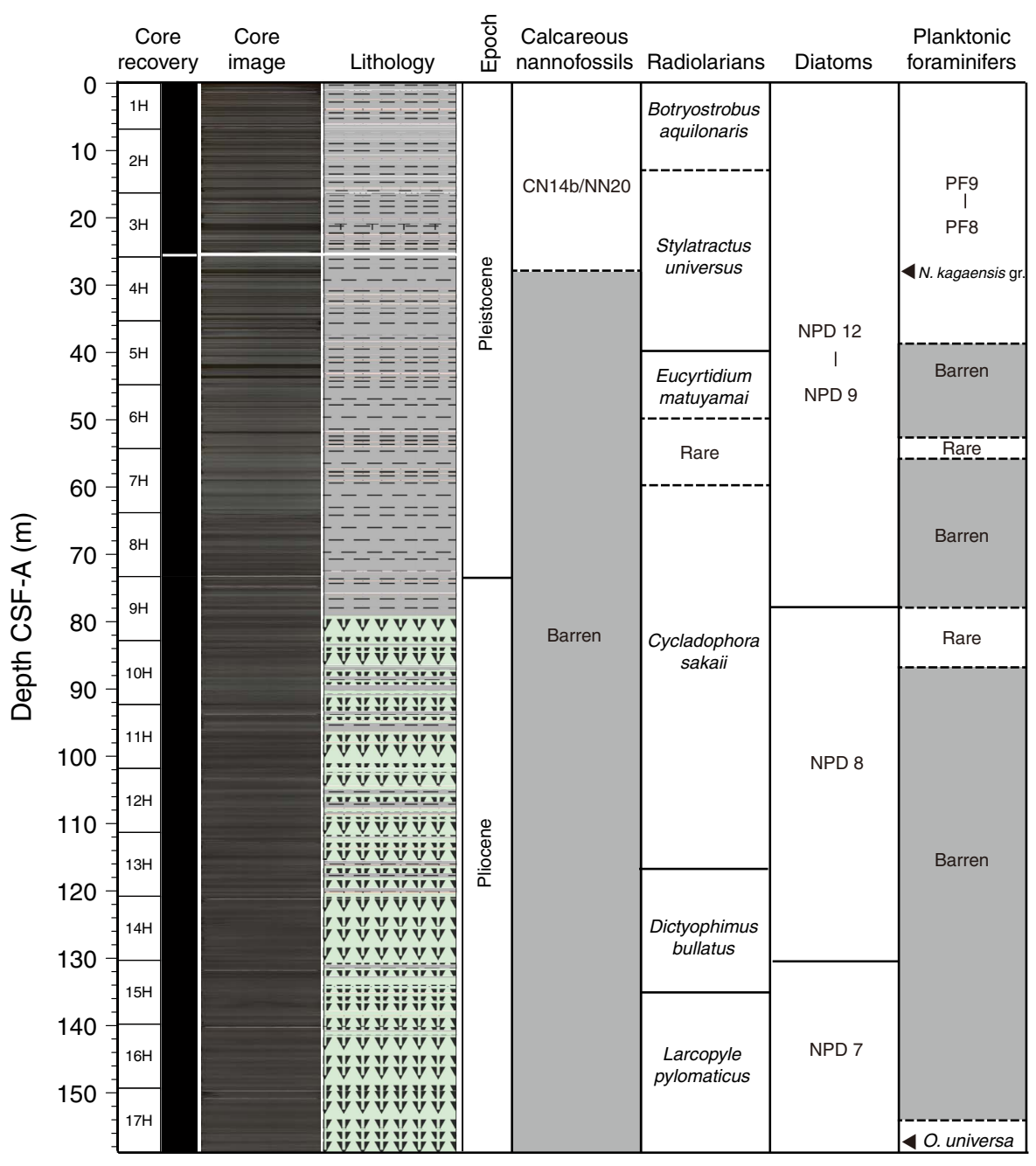


Figure F21. Age-depth profile, Site U1424. Paleomagnetic datums are from "Paleomagnetism." LO = last occurrence, $\mathrm{FO}=$ first occurrence, $\mathrm{RD}=$ rapid decrease, $\mathrm{RI}=$ rapid increase.

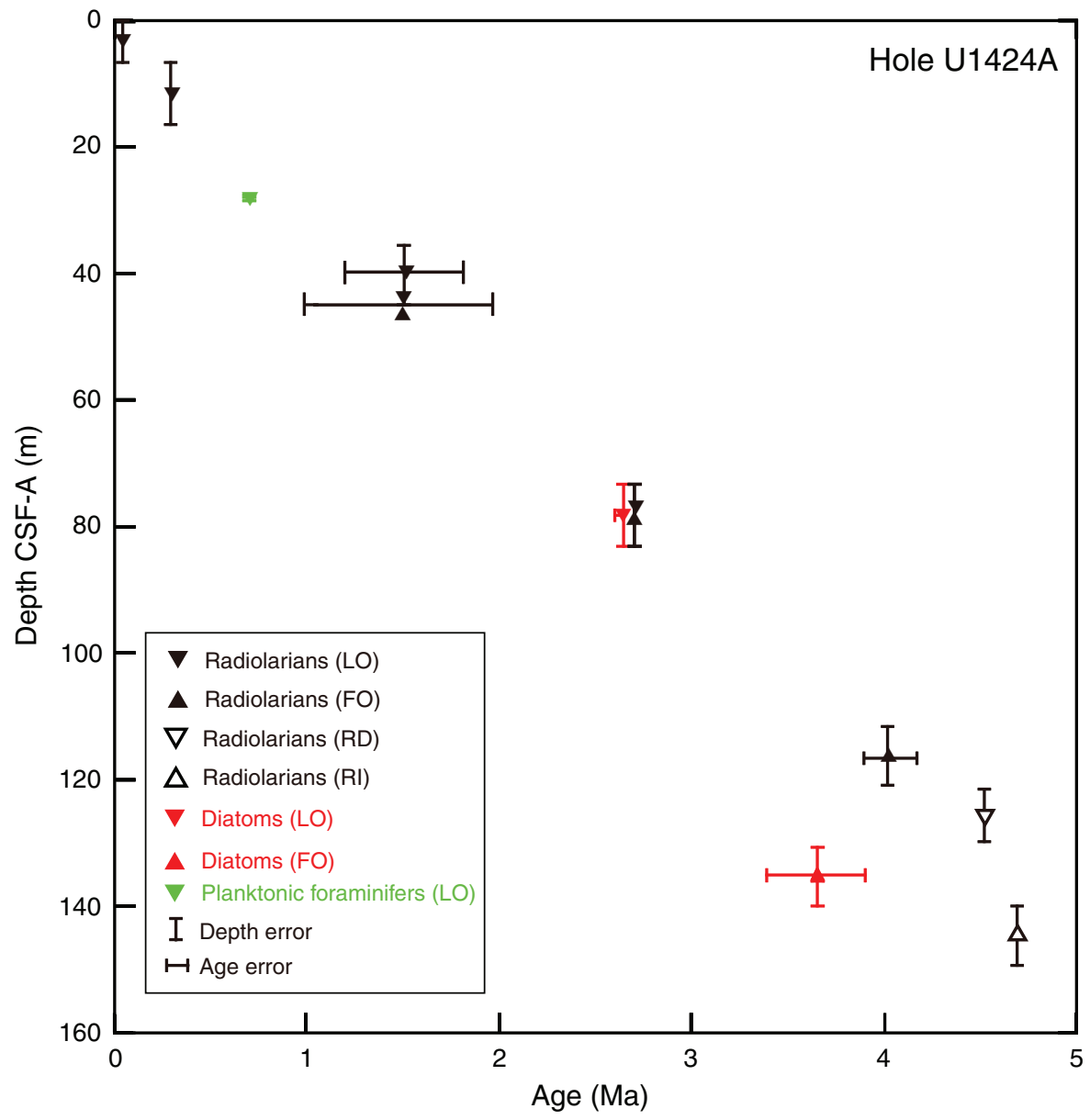


Figure F22. Abundance of siliceous and calcareous microfossils, Site U1424. B = barren, R = rare, F = few, C = common, $\mathrm{A}=$ abundant, $\mathrm{D}=$ dominant.

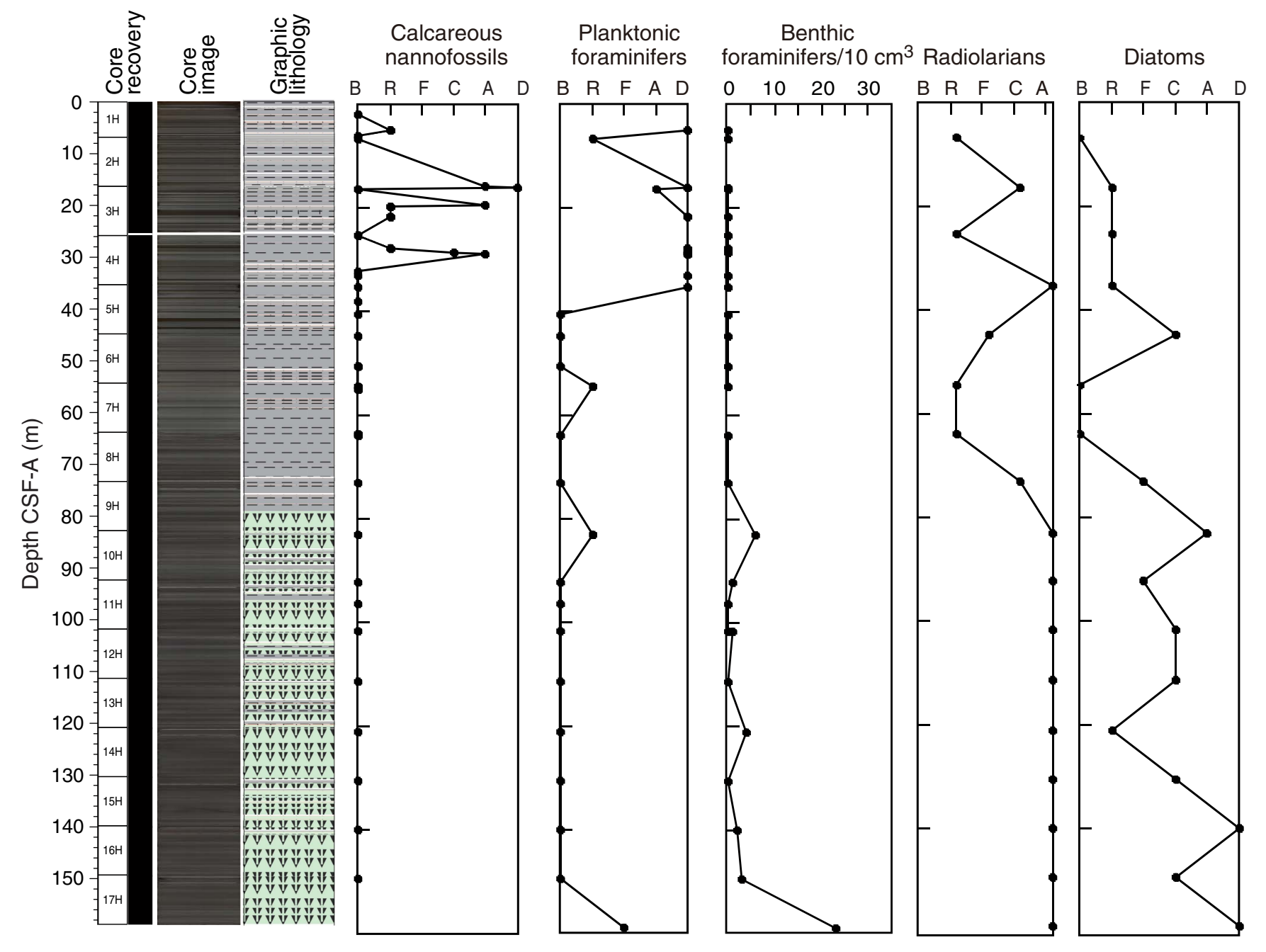


Figure F23. Organically cemented agglutinated and selected calcareous foraminifers and one ostracod. Scale bars $=100 \mu \mathrm{m}$ except Figure 8 and 10 scale bars $=200 \mu \mathrm{m}$; Figure 9 field of view $=35 \mu \mathrm{m} .1-4,6,11$. Section 346-U1424A-1H-1 (mudline sample); $(1,2)$ Aschemonella sp.; $(3,4,6)$ Rhabdammina sp.; (11) Pullenia quinqueloba. 5, 7. Miliammina echigoensis (Sample 346-U1424C-5H-CC). 8-10. Pyritized Aschemonella sp. (Sample 346-U1424A-17H-CC); (8, 9) detail of wall structure. 12, 13. Quinqueloculina akneriana (Sample 346-U1424A11H-CC). 14. Ostracod Henryhowella cf. Henryhowella circumdentata (left valve).

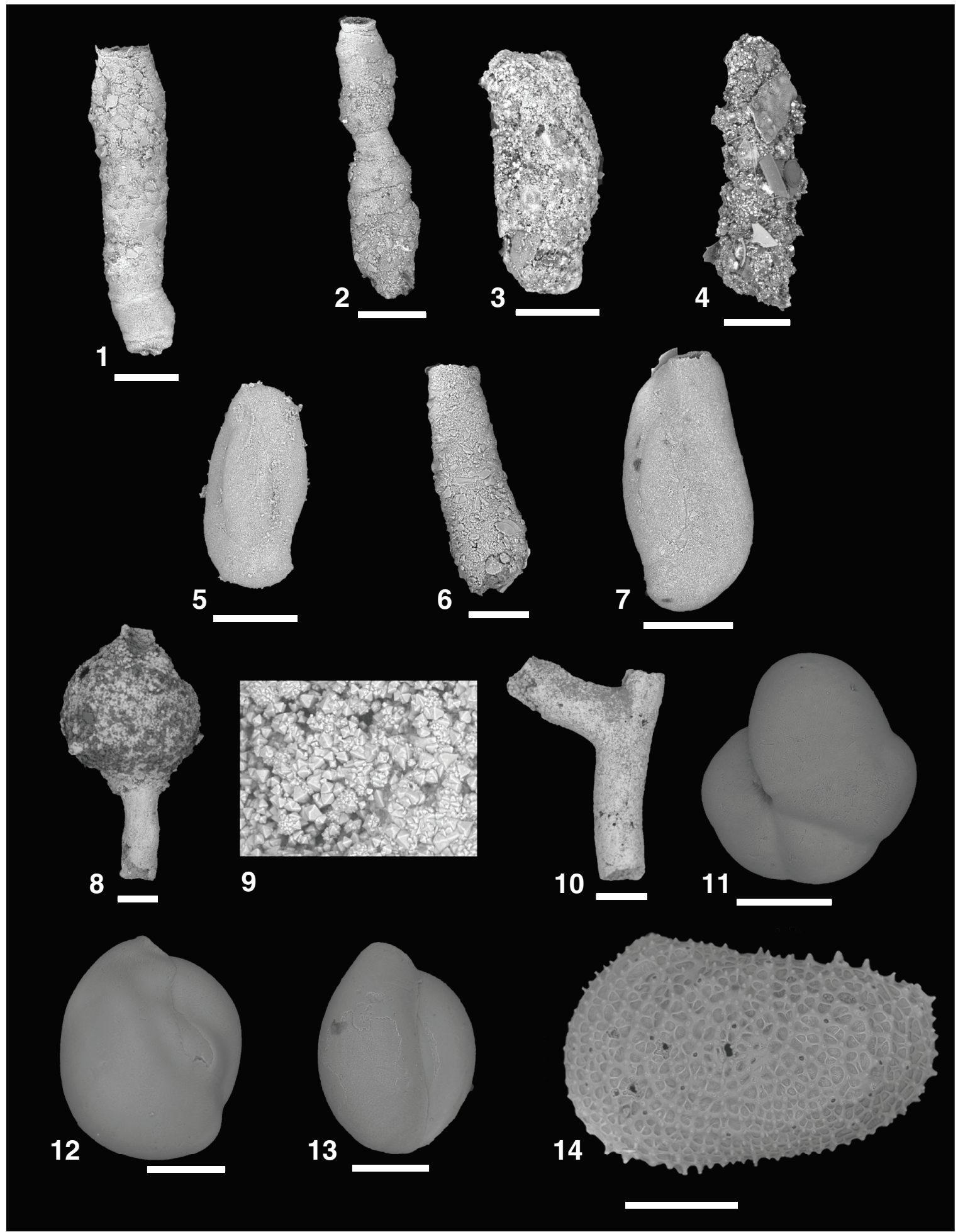


Figure F24. Abundant pyritized agglutinated foraminifers Aschemonella spp. (Sample 346-U1424C-5H-CC). Scale $=$ each side of the square is $3.5 \mathrm{~mm}$.

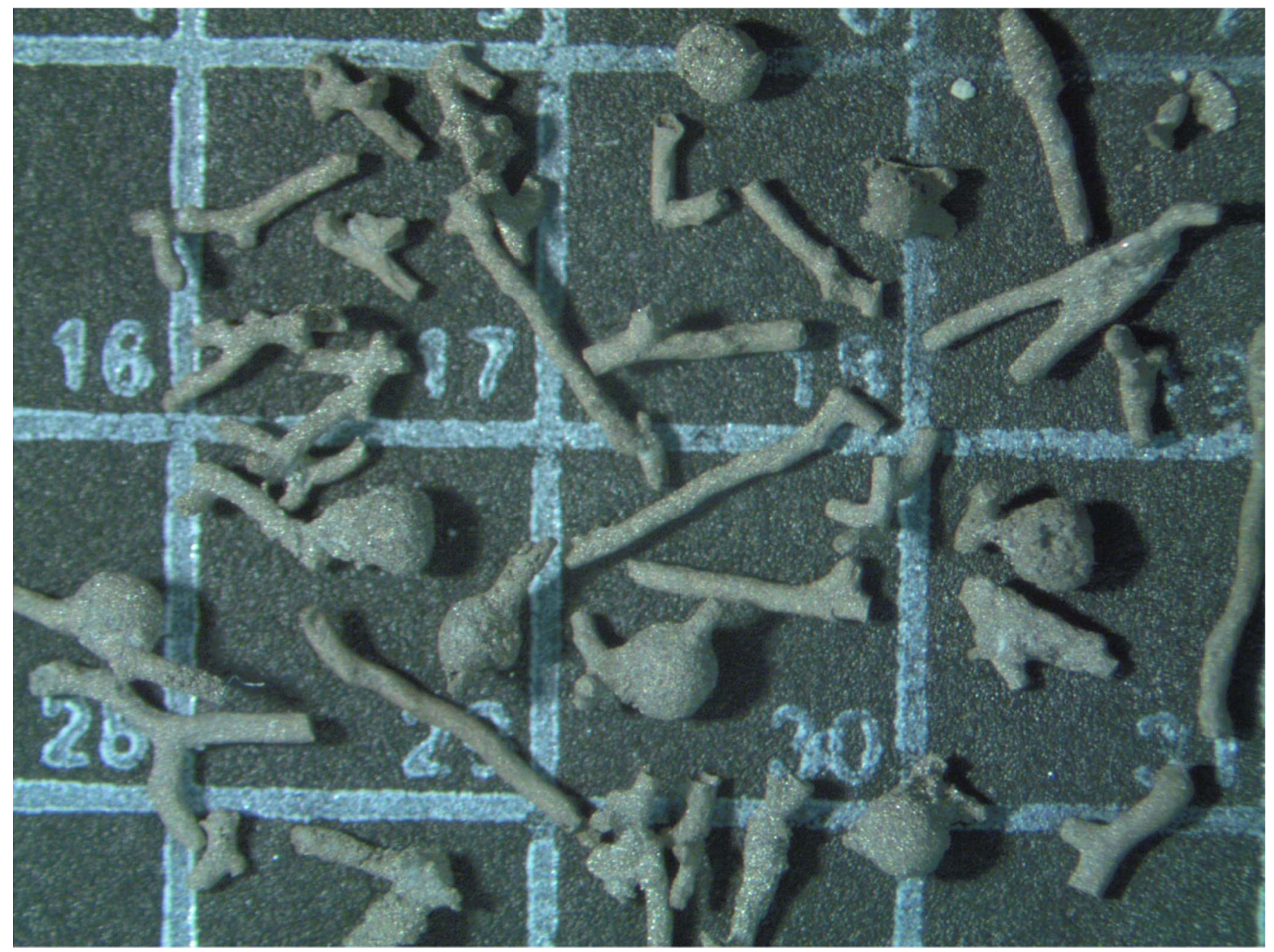


Figure F25. Solid-phase contents of discrete sediment samples, Site U1424. TC = total carbon, TOC = total organic carbon, $\mathrm{TN}=$ total nitrogen.

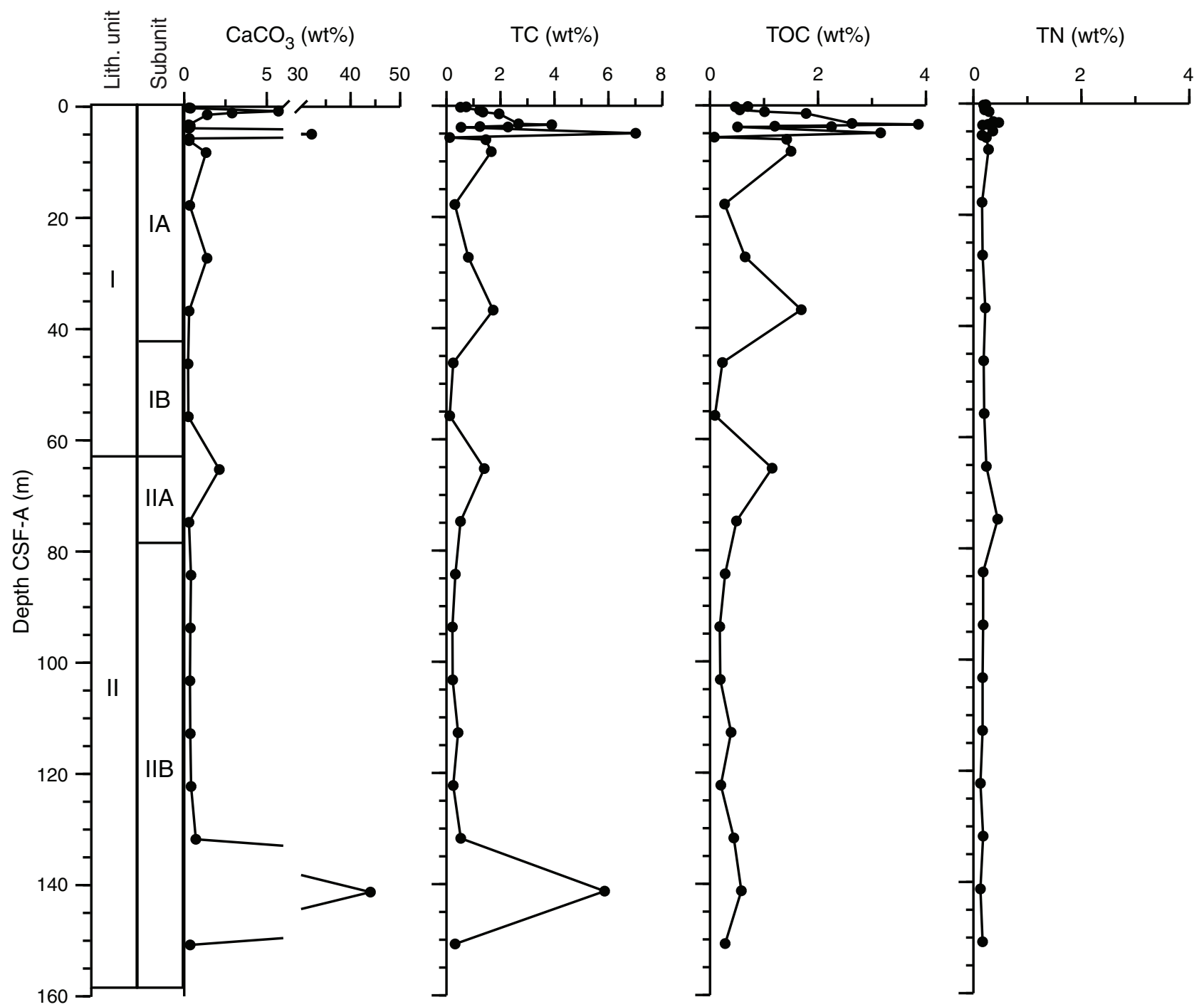


Figure F26. Dissolved iron and manganese profiles over the drilled depth, Site U1424. IW-sq = squeezed interstitial water.

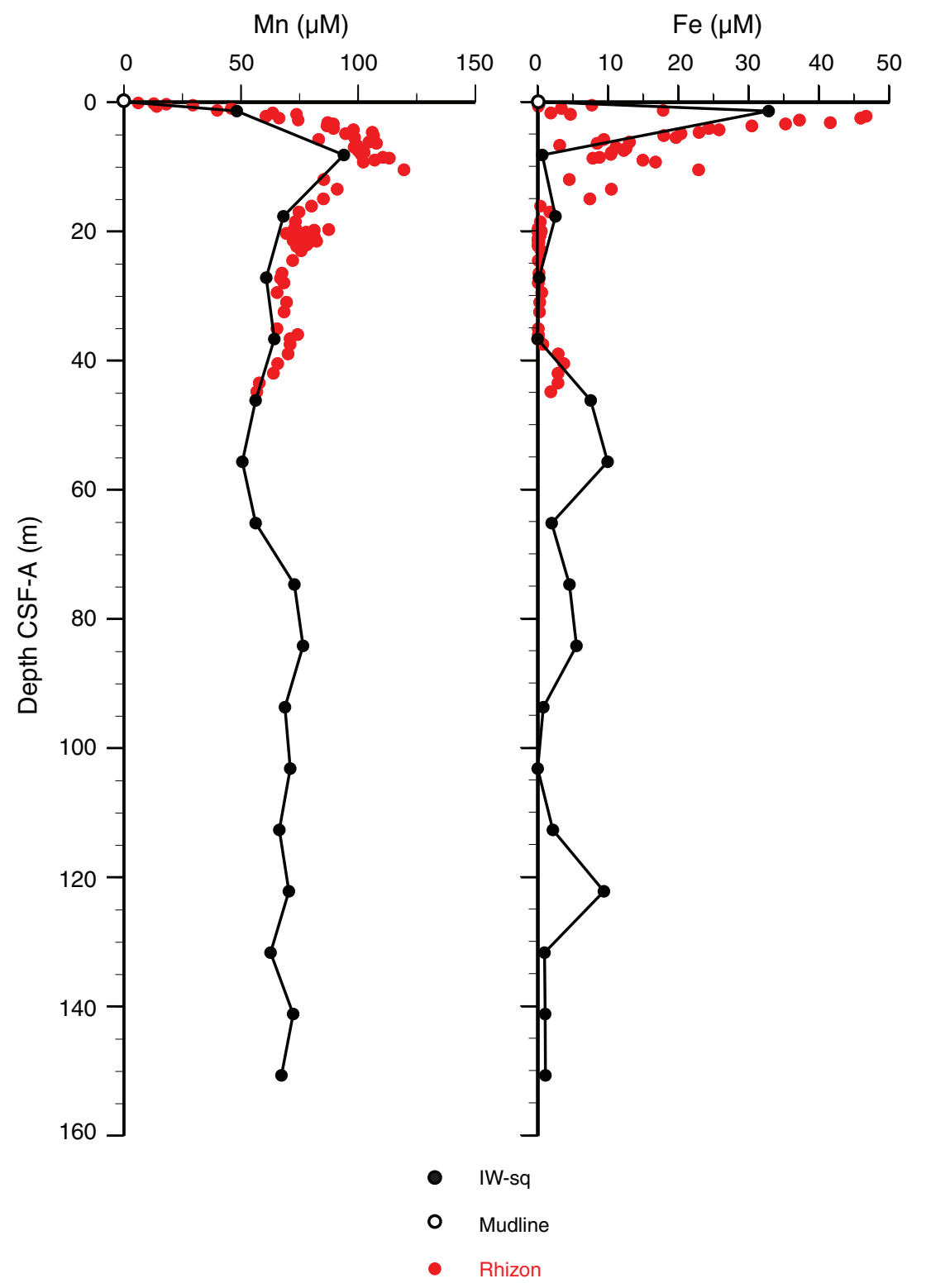


Figure F27. Dissolved iron and manganese profiles over shallow sediment, Hole U1424A. Also shown are pass through magnetic susceptibility (MS) measurements on sediment from the multisensor track. IW-sq = squeezed interstitial water.
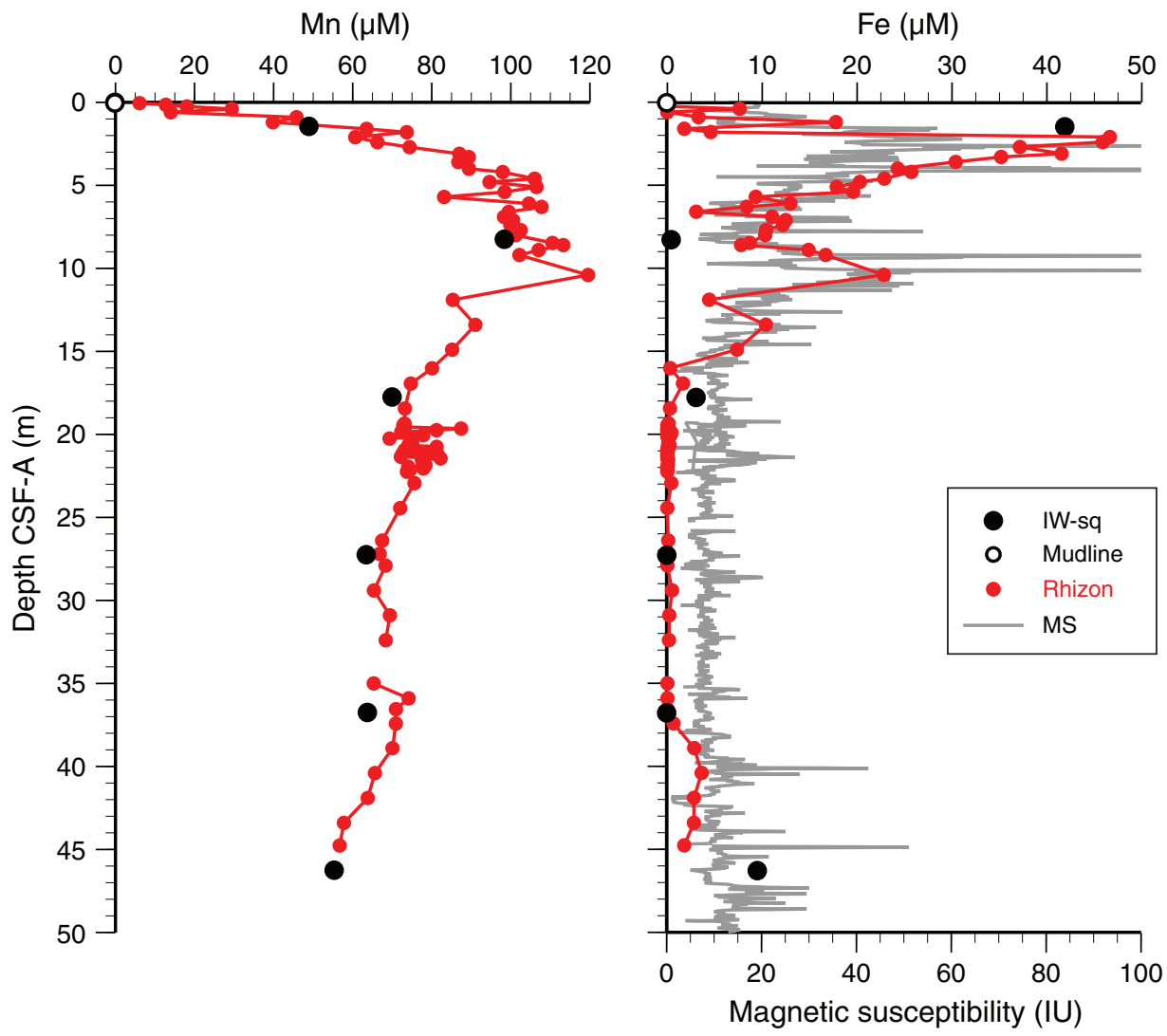
Figure F28. Dissolved alkalinity, ammonium, and phosphate profiles, Site U1424. IW-sq = squeezed interstitial water.

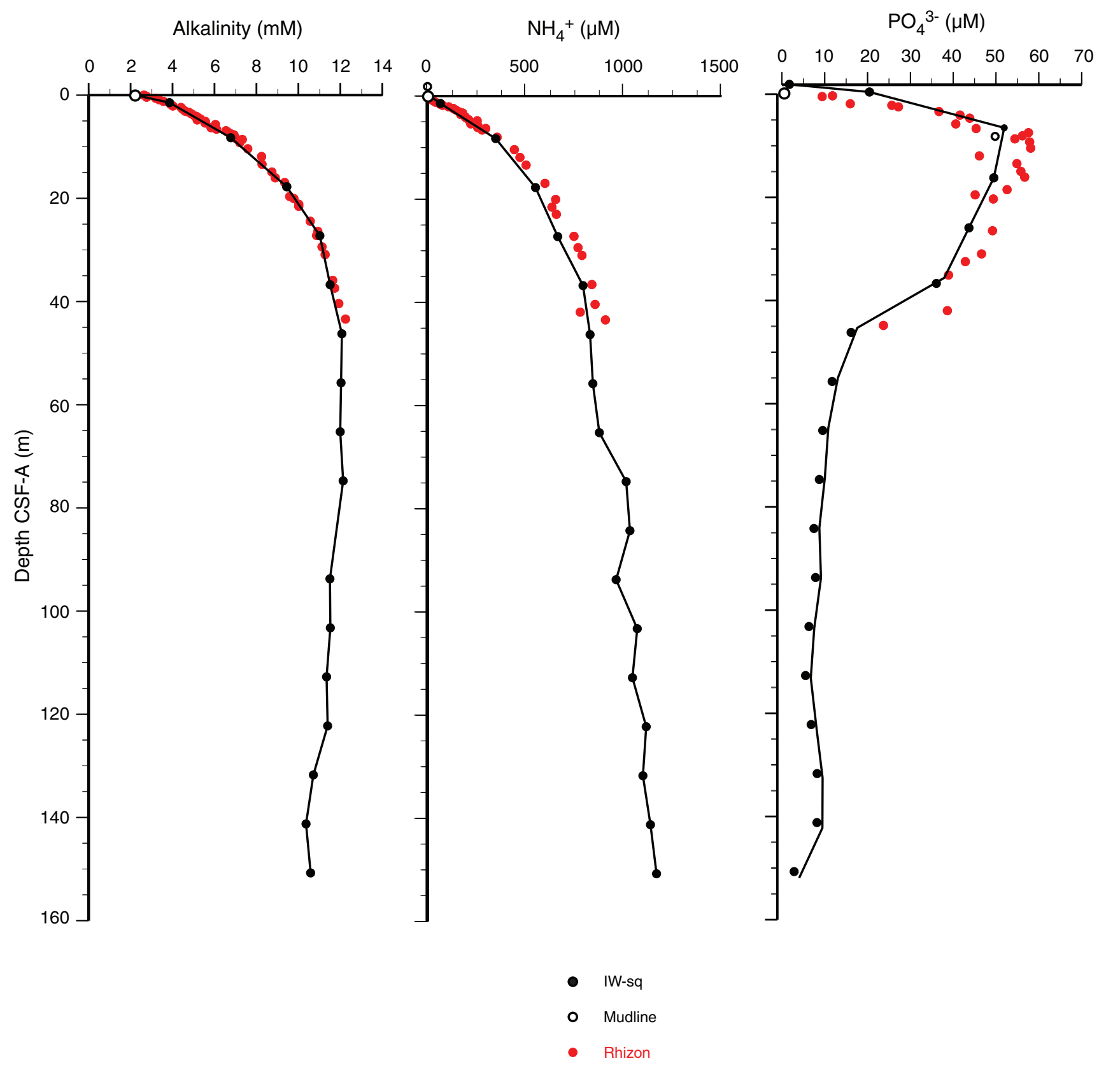


Figure F29. Ammonium concentrations and color reflectance $\mathrm{a}^{*}$ near the mudline from squeezed interstitial water (IW-sq) and Rhizon samples, Site U1424.

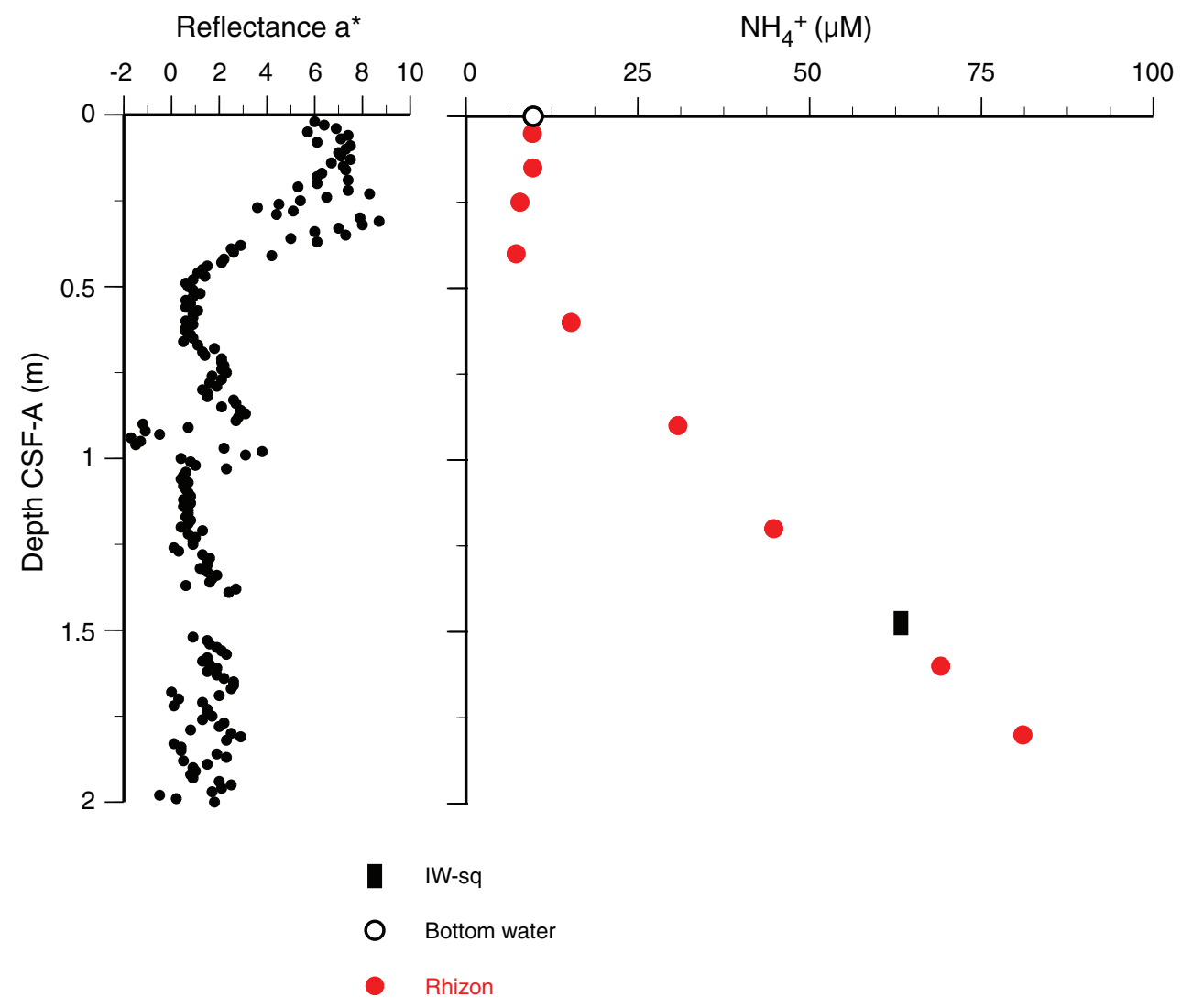


Figure F30. Headspace $\mathrm{CH}_{4}$ concentrations with depth at Site U1424 with Sites U1422 and U1423 for comparison. Note that values are not meaningful at depths where $\mathrm{CH}_{4}$ surpasses saturation at 1 atm pressure.

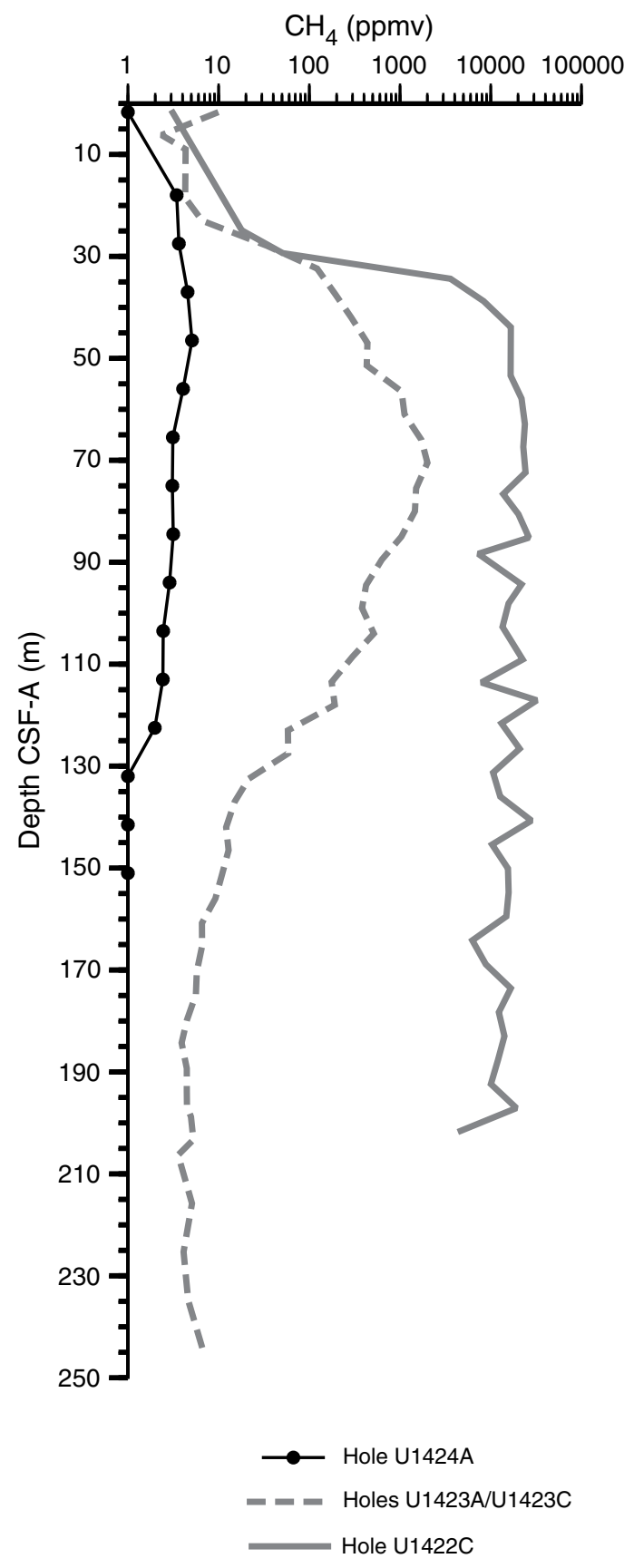


Figure F31. Headspace $\mathrm{CH}_{4}$ and dissolved $\mathrm{SO}_{4}{ }^{2-}$ concentrations with depth, Site U1424. IW-sq $=$ squeezed interstitial water.
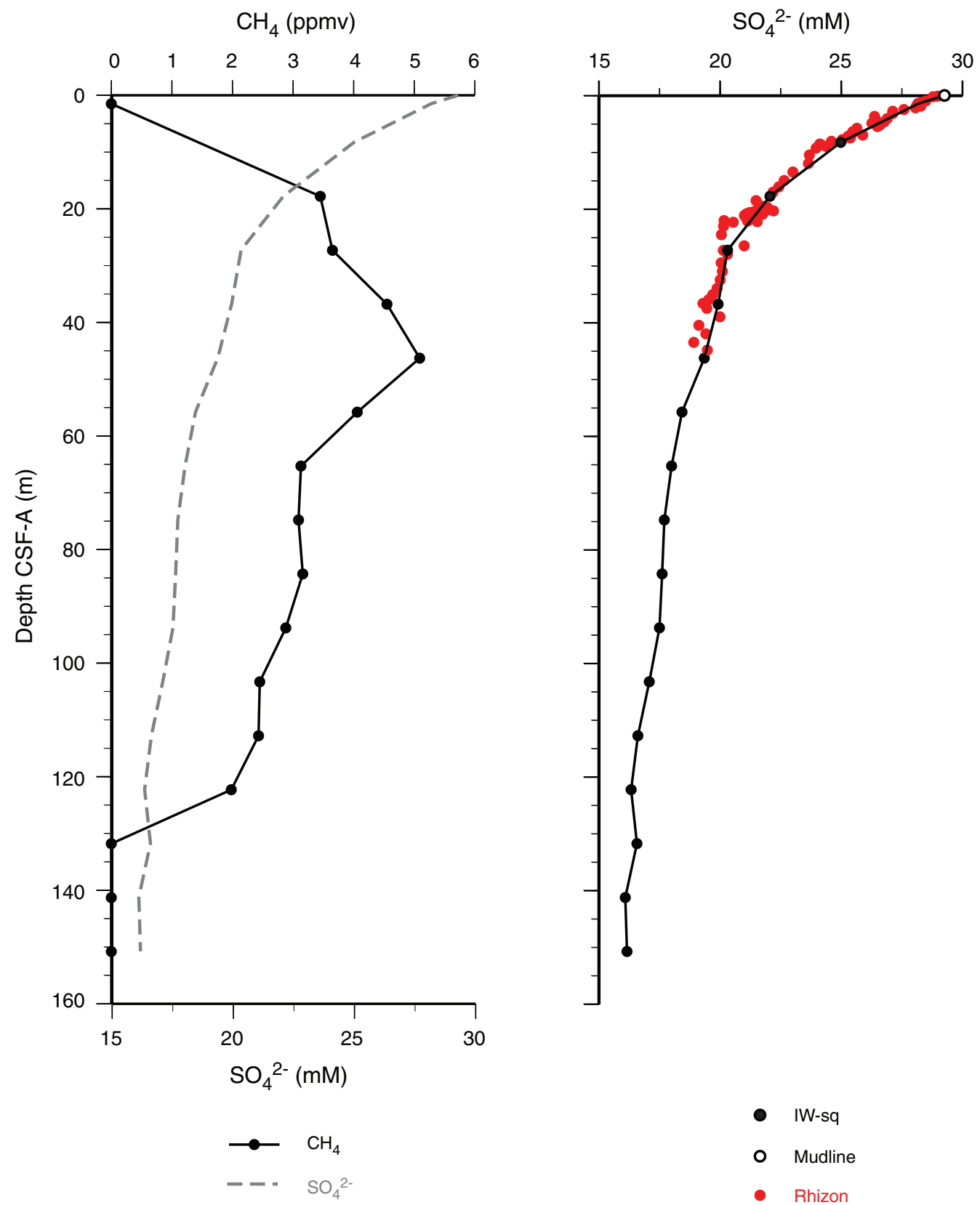
Figure F32. Dissolved barium profile, Site U1424. IW-sq = squeezed interstitial water.

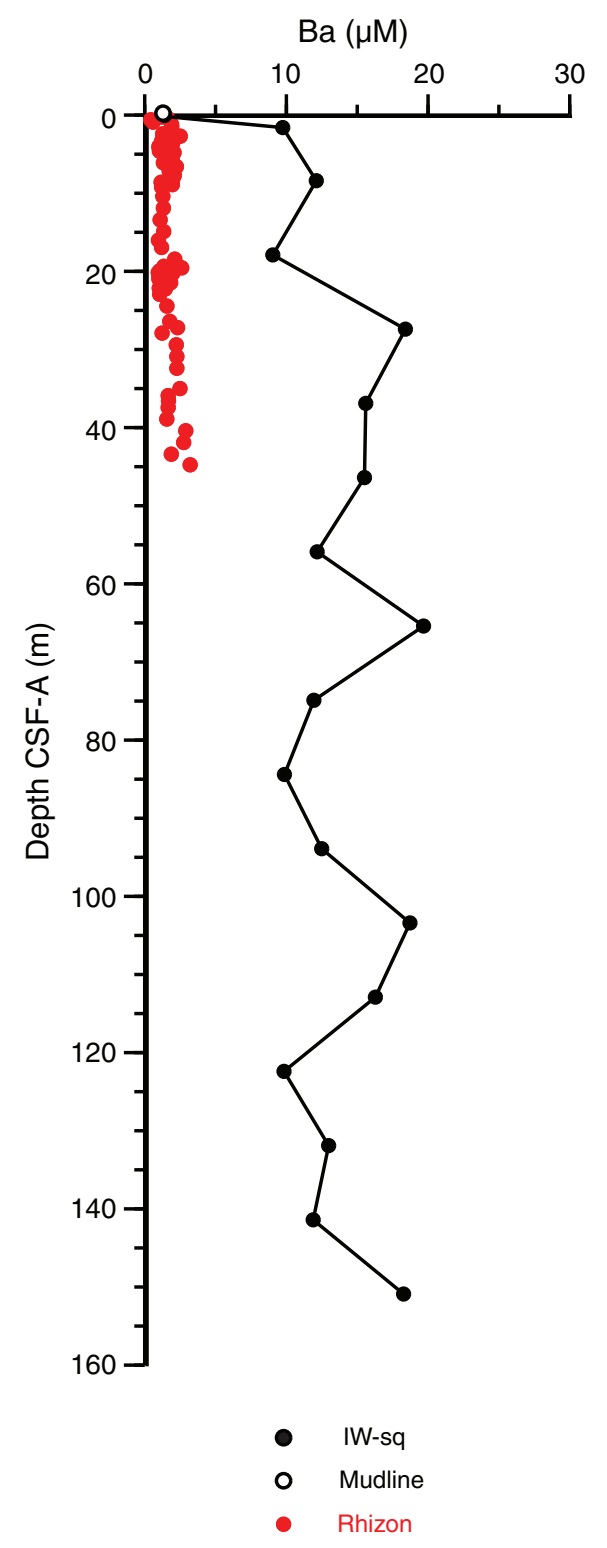


Figure F33. Dissolved calcium, magnesium, and strontium profiles, Site U1424. IW-sq = squeezed interstitial water.

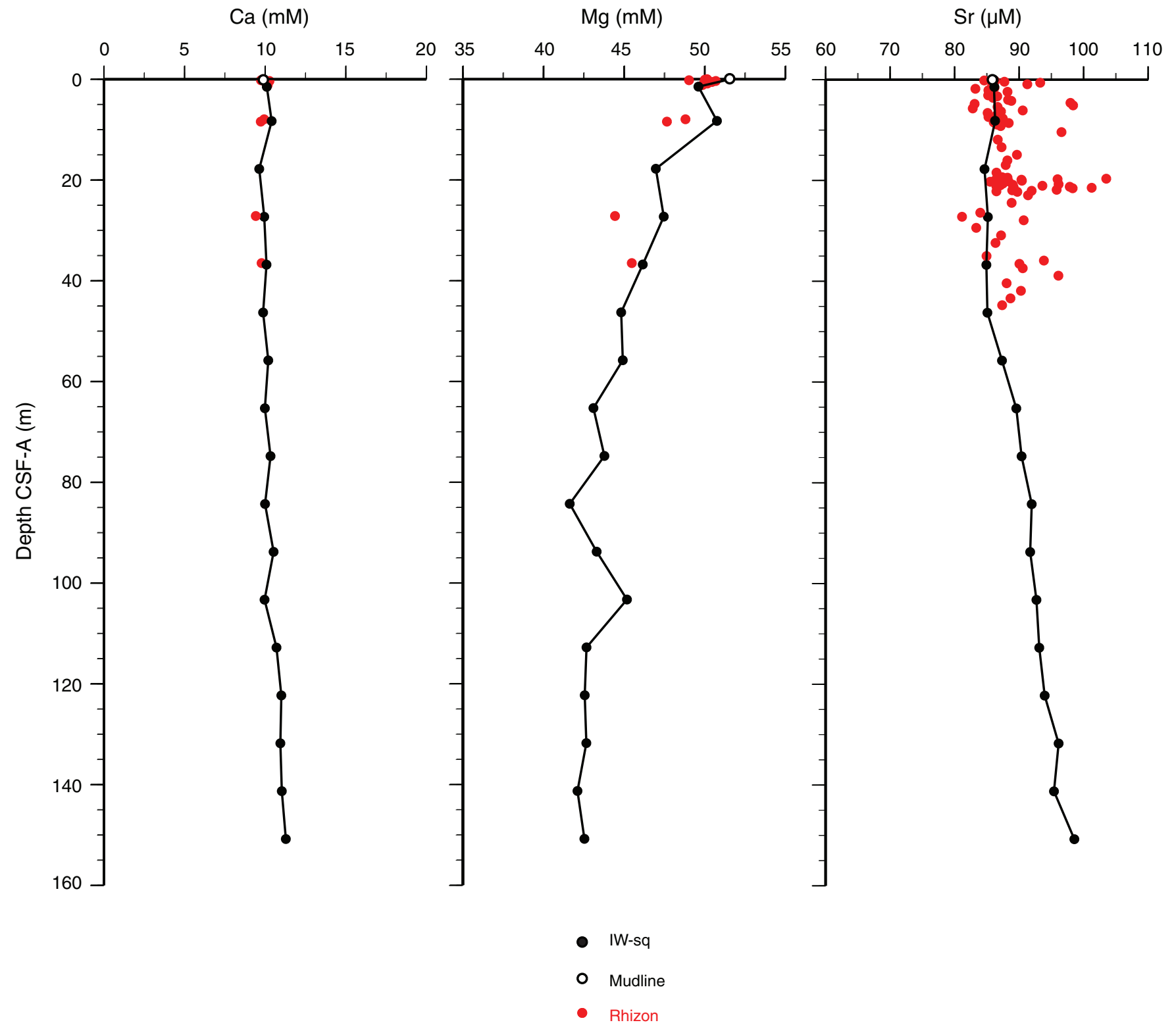


Figure F34. Dissolved $\mathrm{Cl}^{-}, \mathrm{Na}$, and K profiles, Site U1424. IW-sq = squeezed interstitial water.

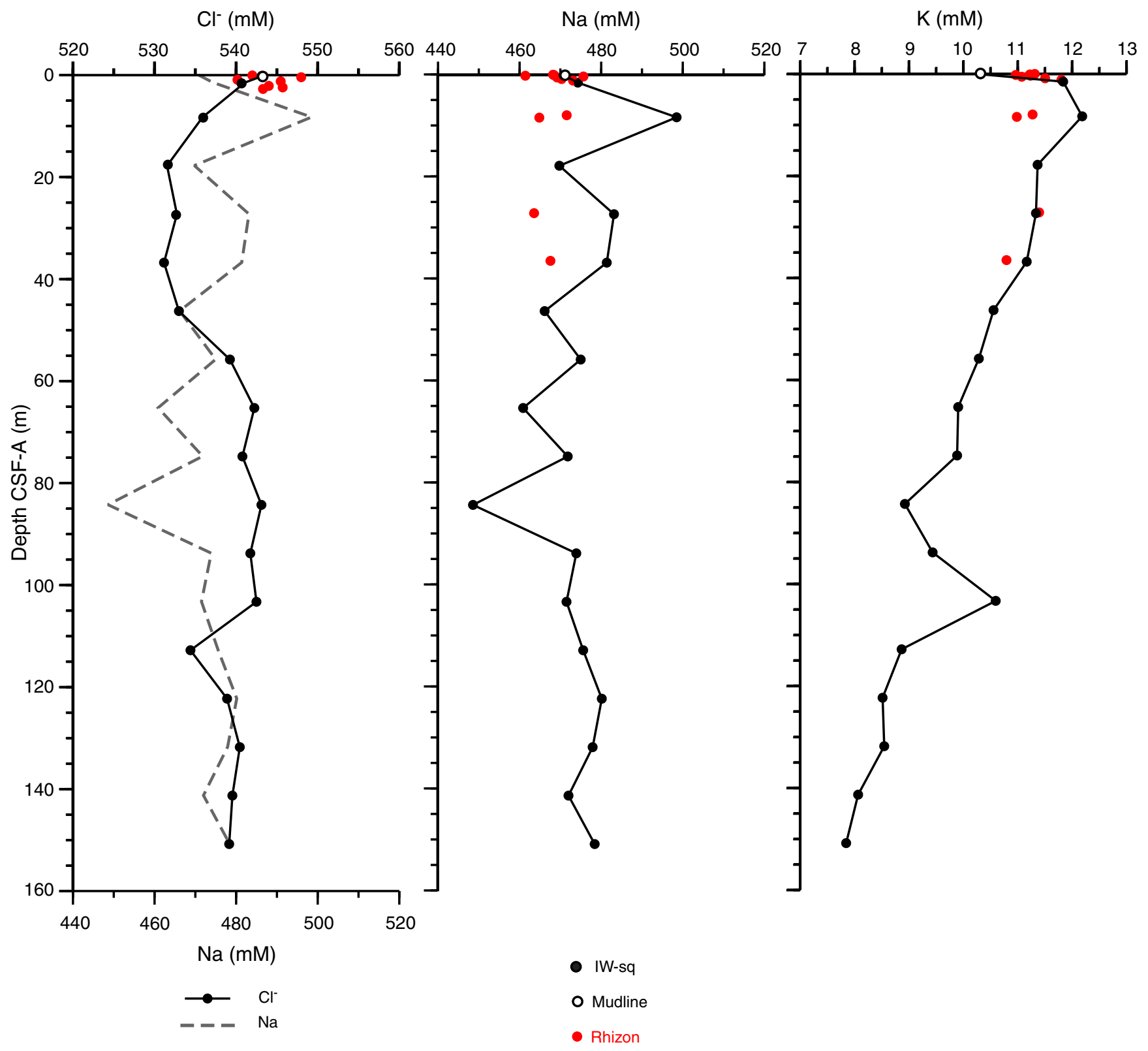


Figure F35. Dissolved B, Li, and Si concentrations with depth, Site U1424. IW-sq = squeezed interstitial water.

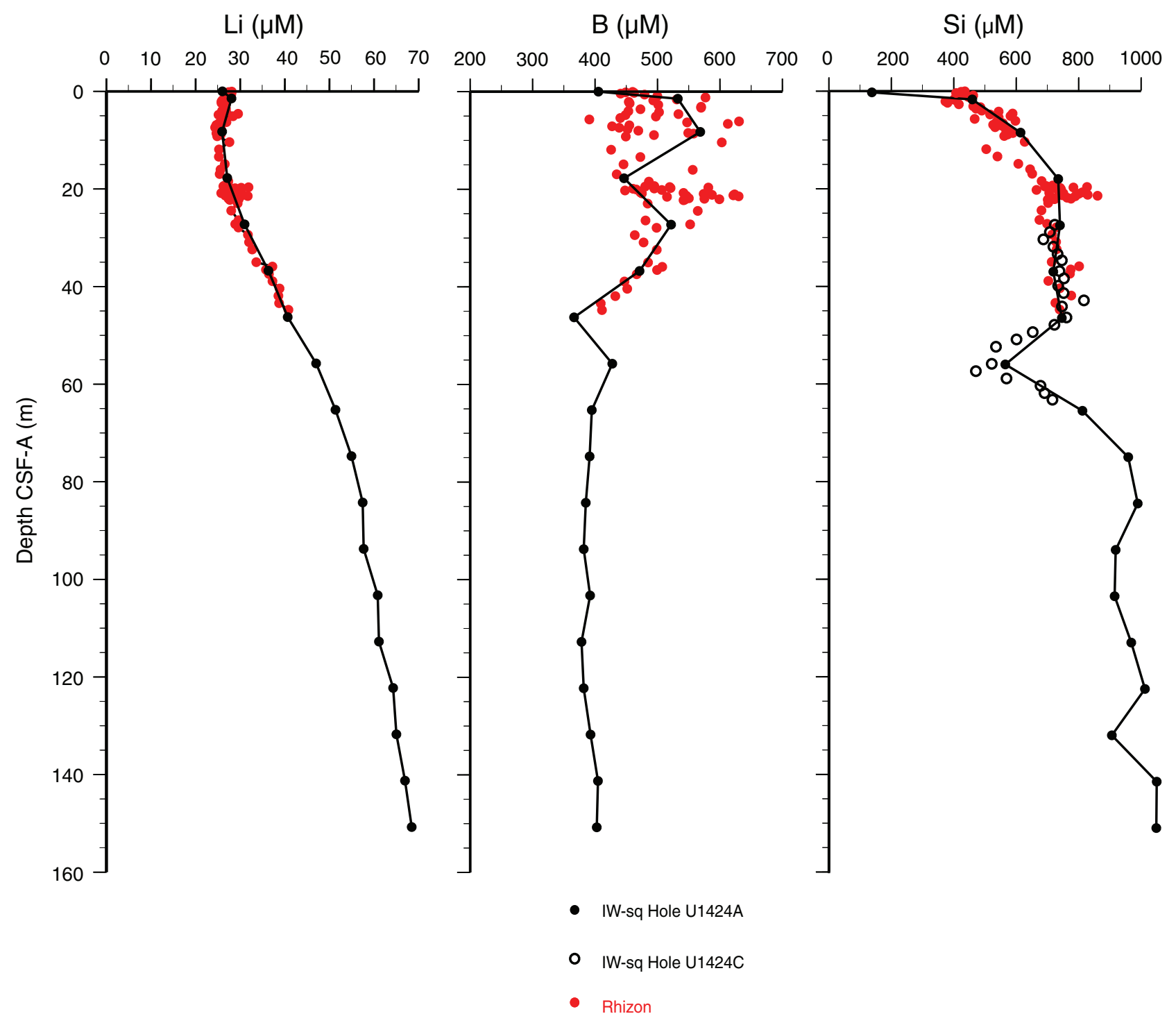


Figure F36. Paleomagnetism after $20 \mathrm{mT}$ AF demagnetization, Site U1424. Chron column: black = normal polarity, white $=$ reversed polarity, gray $=$ zones or polarity boundaries without clear magnetostratigraphic interpretation. Inclination column: thin black dashed lines $=$ expected geocentric axial dipole inclinations at the site latitude during reversed (left) and normal (right) polarities, triangles along the left side mark depths where discrete paleomagnetic cube samples were collected (orange = discrete samples measured during the expedition). Declination column: gray dots $=$ measured declination values, green dots $=$ declination values corrected using core orientation data collected by the FlexIT tool. Susceptibility column: SHMSL and WRMSL measured values are shown in magenta and gray dots, respectively. A. Hole U1424A. (Continued on next two pages.)

A Hole U1424A

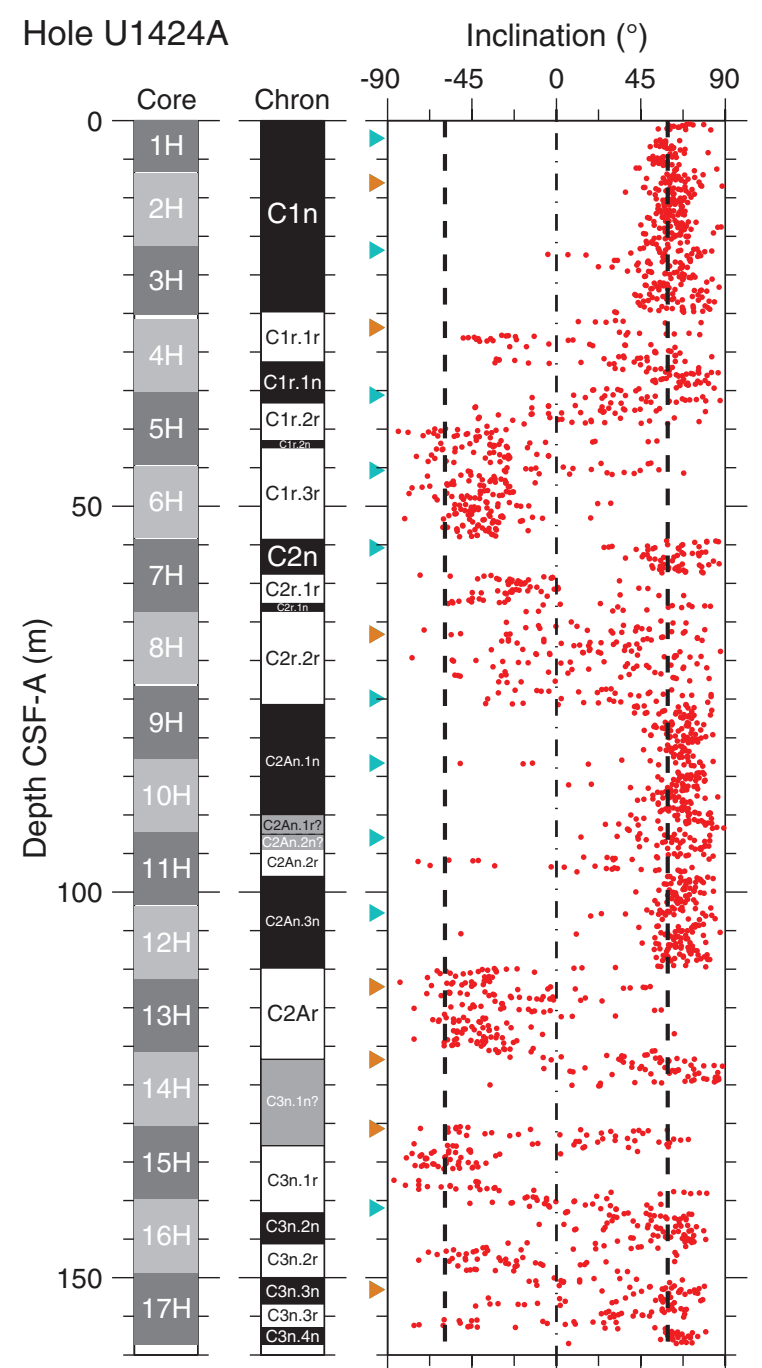

Inclination $\left({ }^{\circ}\right)$

\begin{tabular}{cccc}
\multicolumn{8}{c}{ Declination $\left({ }^{\circ}\right)$} \\
90 & 0 & 90 & $180 \quad 270$
\end{tabular}
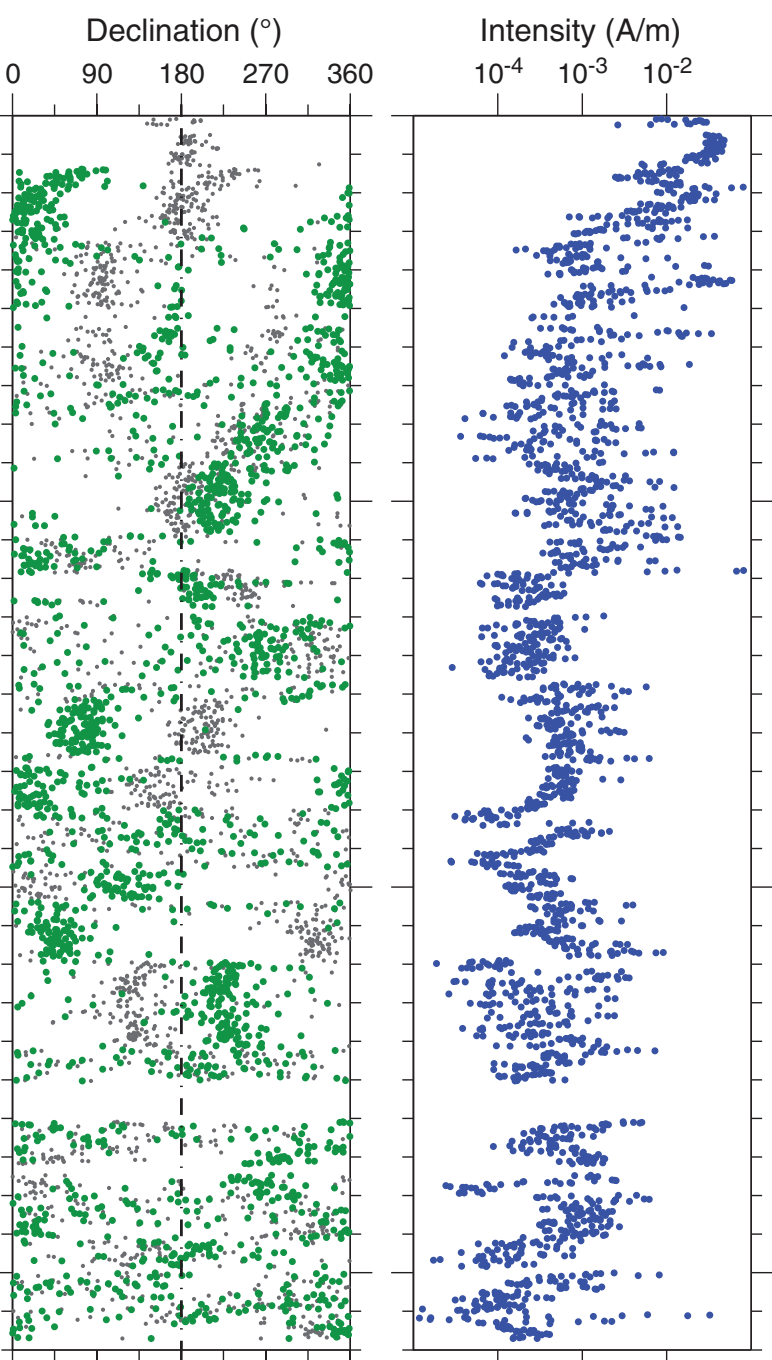

Susceptibility $\left(10^{-5} \mathrm{SI}\right)$

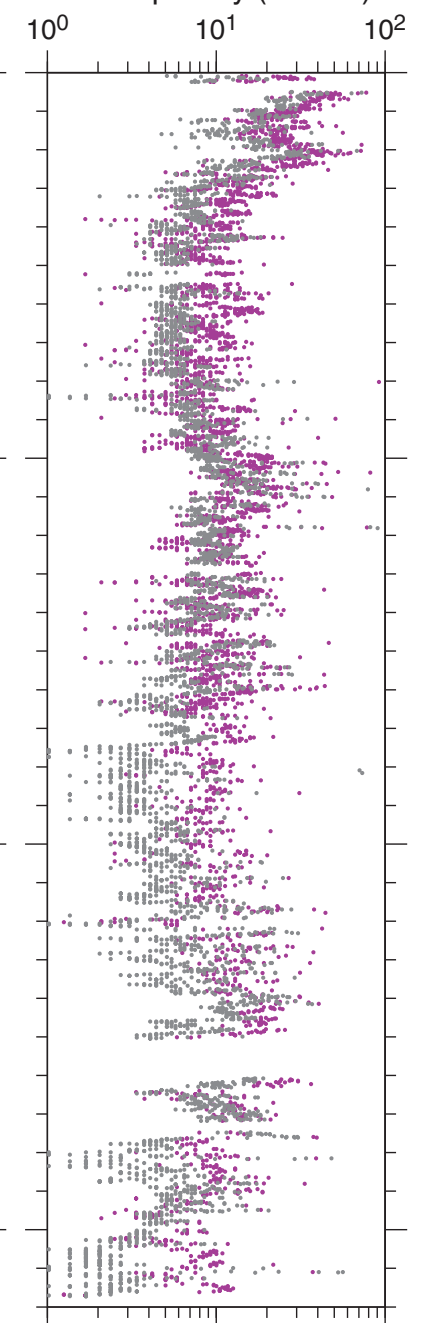


Figure F36 (continued). B. Hole U1424B. (Continued on next page.)

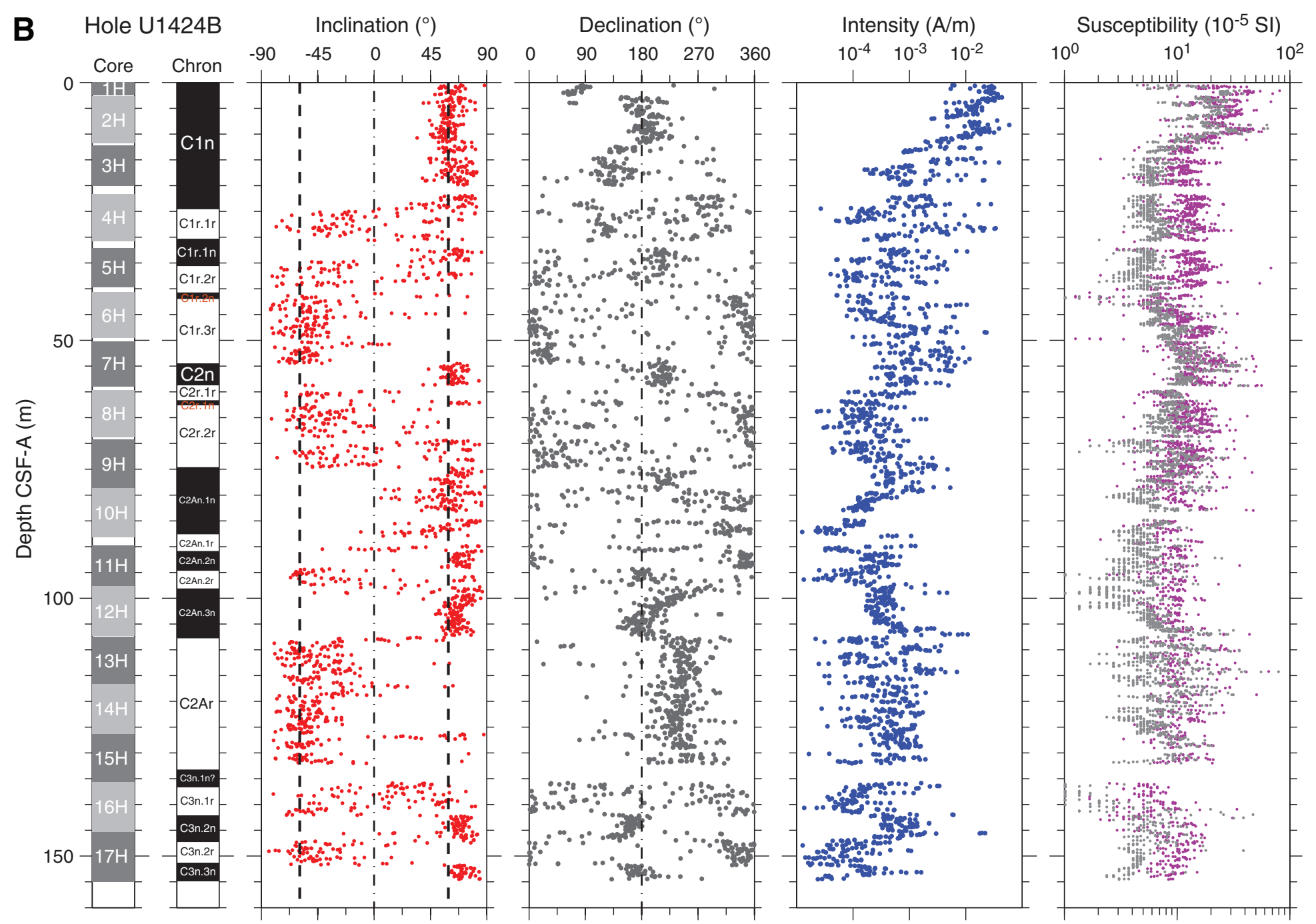


Figure F36 (continued). C. Hole U1424C.

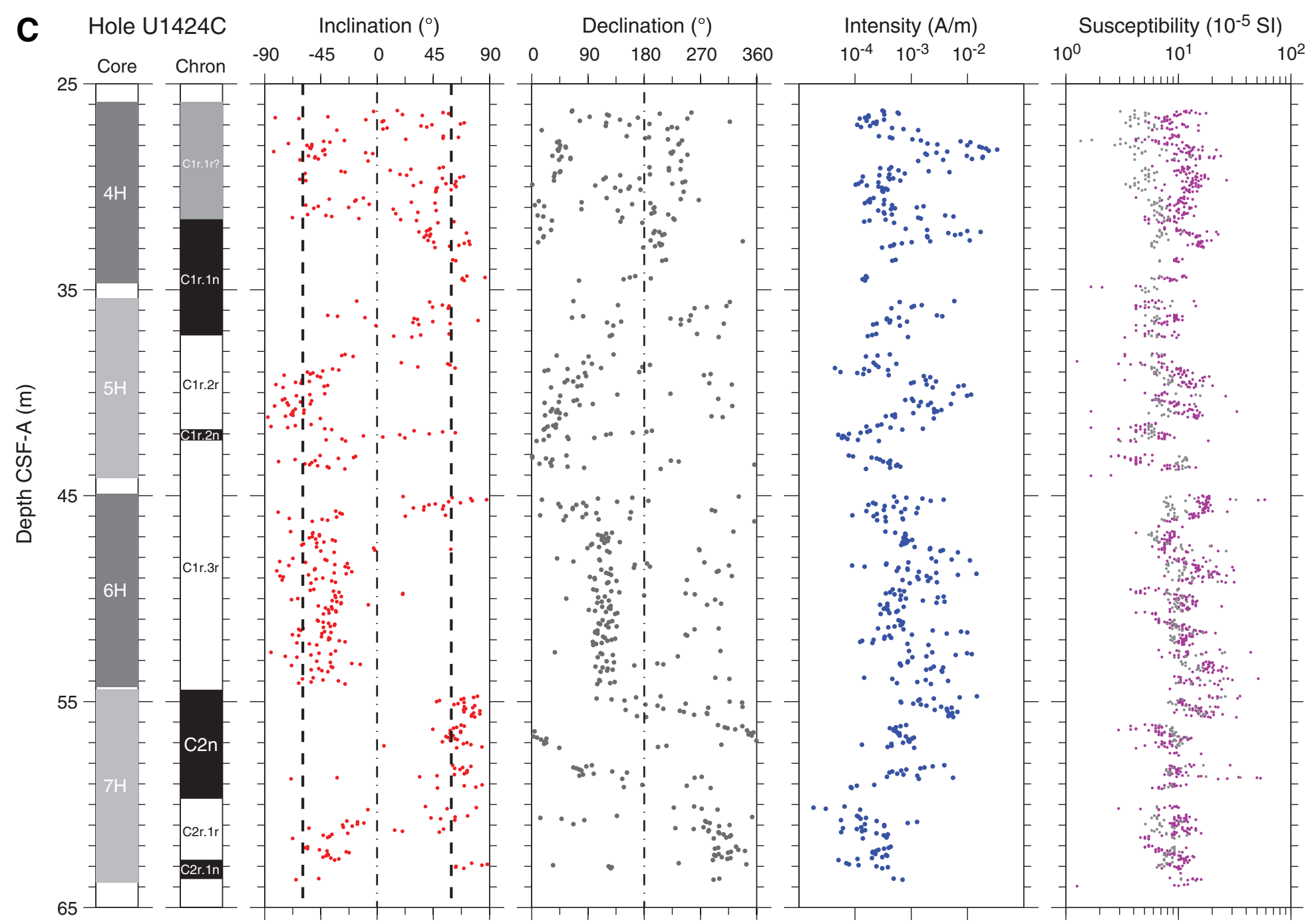


Figure F37. A-G. AF demagnetization results for seven discrete samples, Site U1424. For each sample, the left plot shows the intensity variation with progressive demagnetization. The middle and right plots show the NRM vector measured after each demagnetization treatment on an orthogonal projection (Zijderveld) and on an equal area projection, respectively. In the orthogonal projection plot, squares $=$ horizontal projections, circles $=$ vertical projections. In the equal area projection plot, solid circles $=$ projection data with positive inclinations, open circles $=$ projection data with negative inclinations. Note that on the orthogonal projection (Zijderveld) plot, NRM data before demagnetization have been removed to better display the demagnetized data.

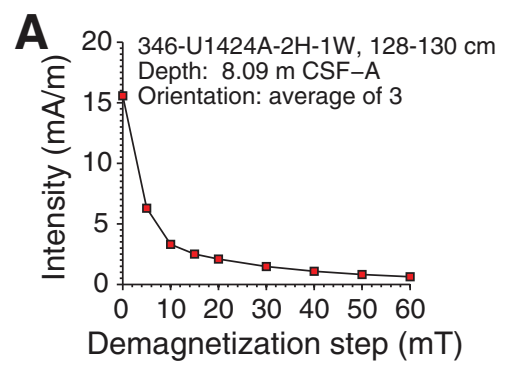

B

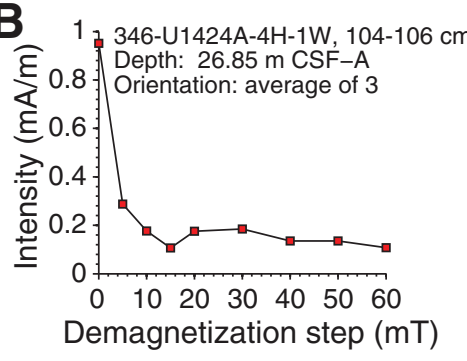

C 4 346-U1424A-8H-2W, $131-133 \mathrm{~cm}$

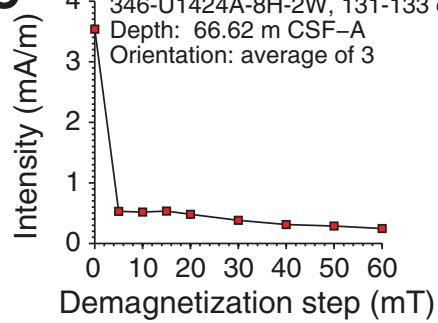

D

D 2 346-U1424A-13H-1W, 98-100 cm

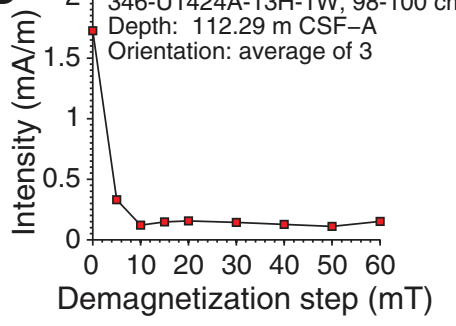

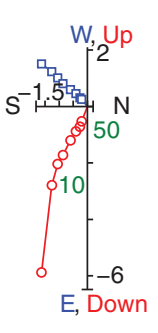
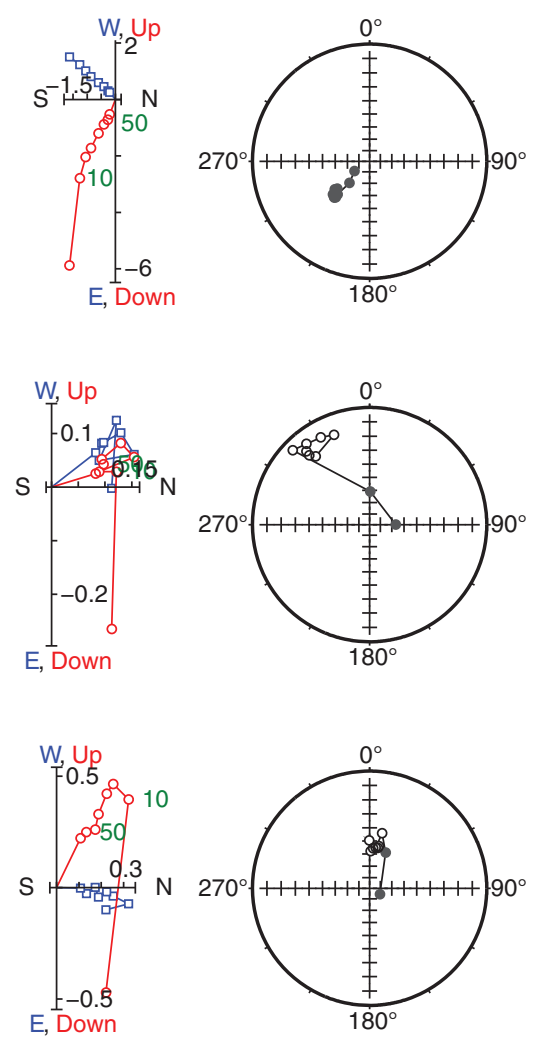

W, Up
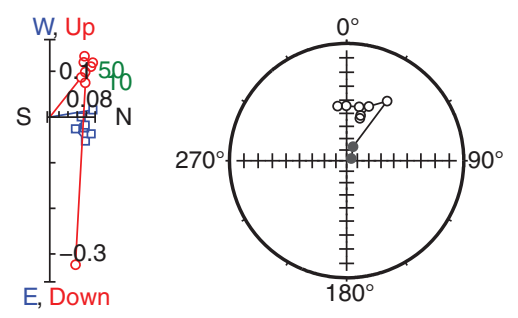

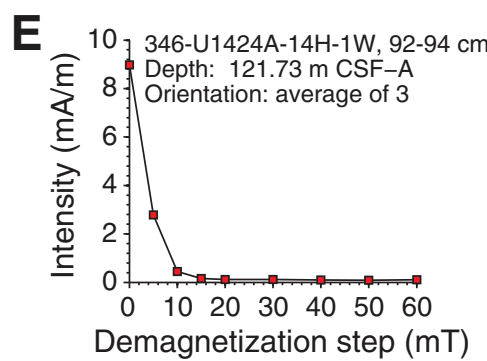

F

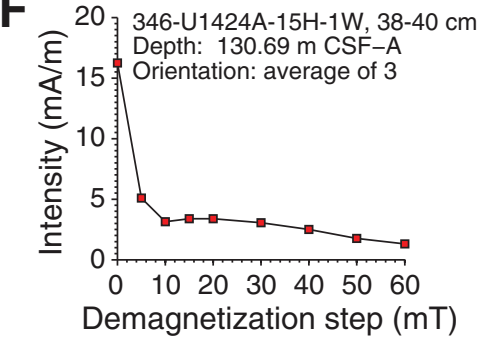

G 0.6 346-U1424A-17H-2W, 73-75 cm

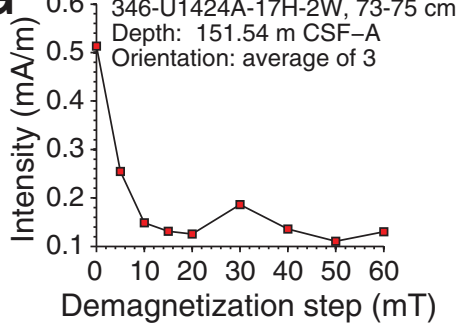

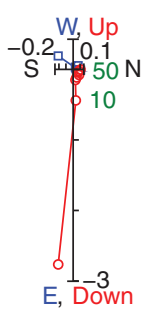
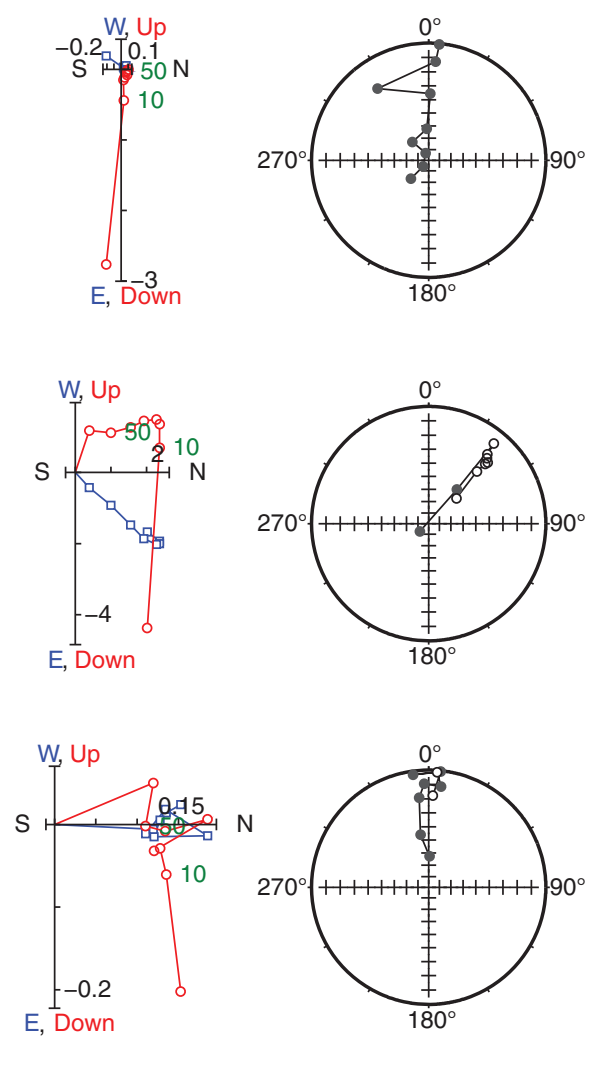
Figure F38. Suite of physical properties measured in Hole U1424A. The first magnetic susceptibility panel shows WRMSL data, whereas the second panel shows WRMSL (black) and point SHMSL (green) data. Gamma ray attenuation (GRA) bulk density was run on the WRMSL. The $P$-wave velocity panel shows WRMSL data. Lowest dotted line $=$ potential hiatus in lithologic Subunit IIB. NGR $=$ natural gamma radiation .

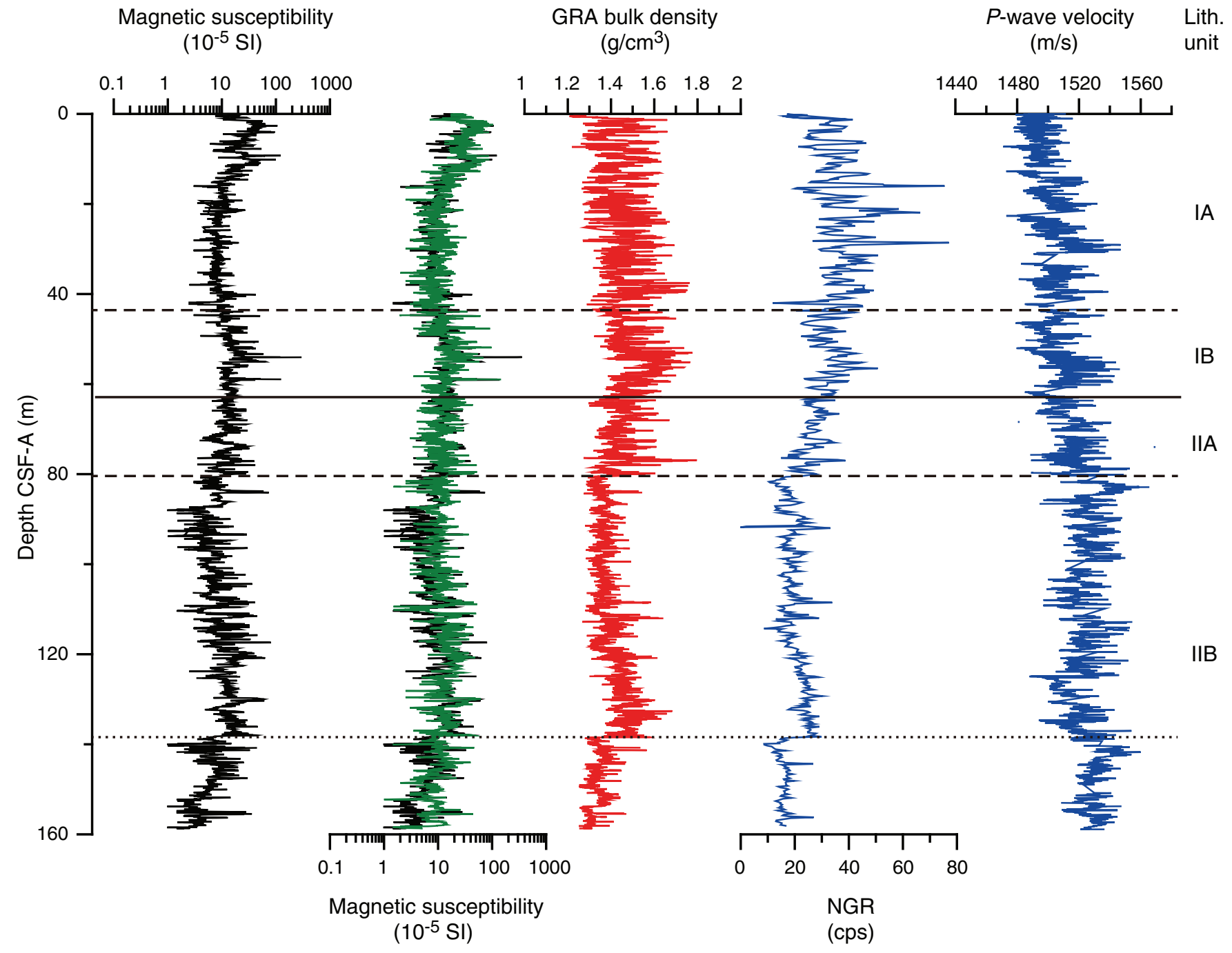


Figure F39. Discrete bulk density, grain density, porosity, water content, and shear strength, Site U1424. Solid symbols = measurements in dark layers. Lowest dotted line = potential hiatus in lithologic Subunit IIB.

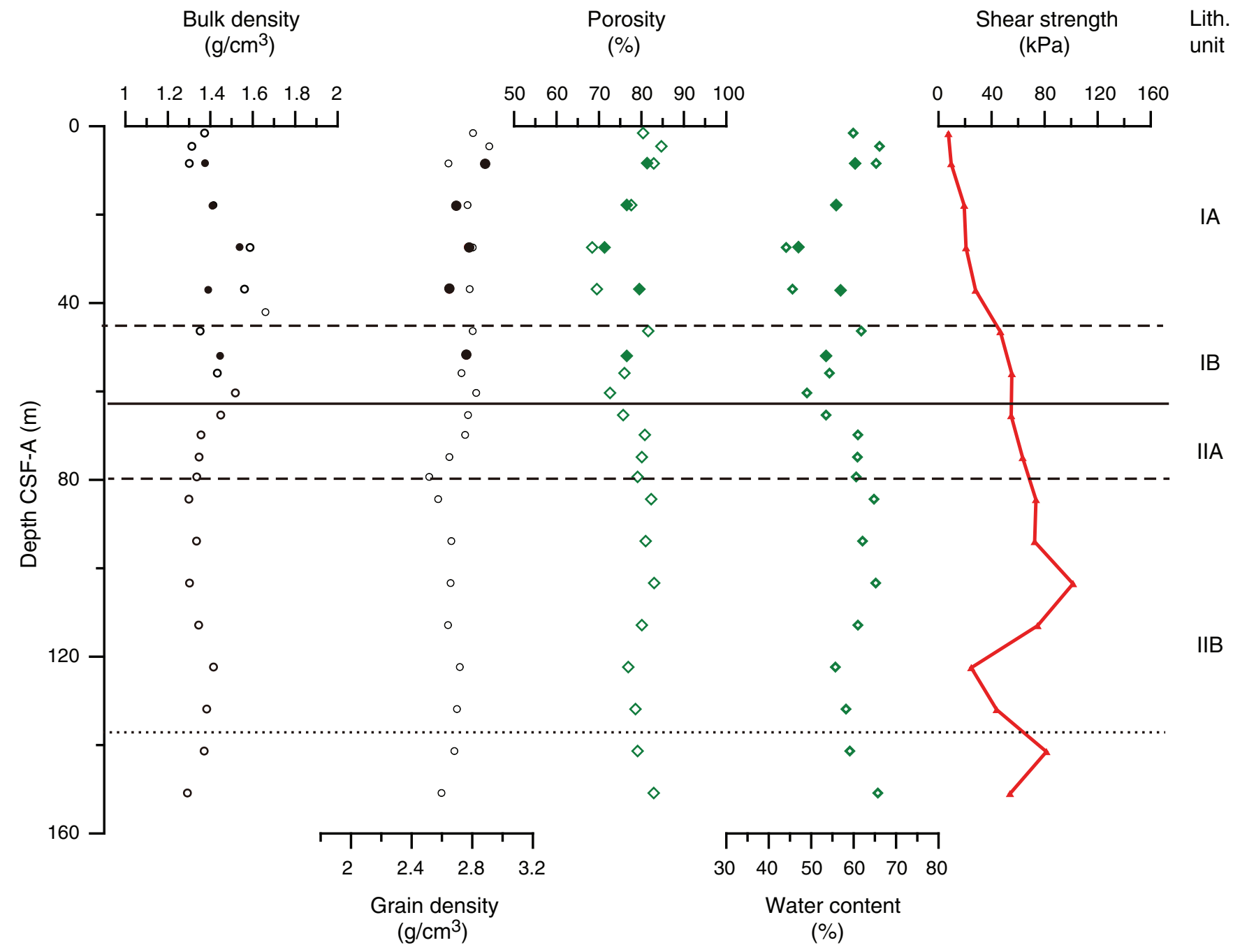


Figure F40. Diffuse reflectance data, Hole U1424A. Lowest dotted line = potential hiatus in lithologic Subunit IIB.

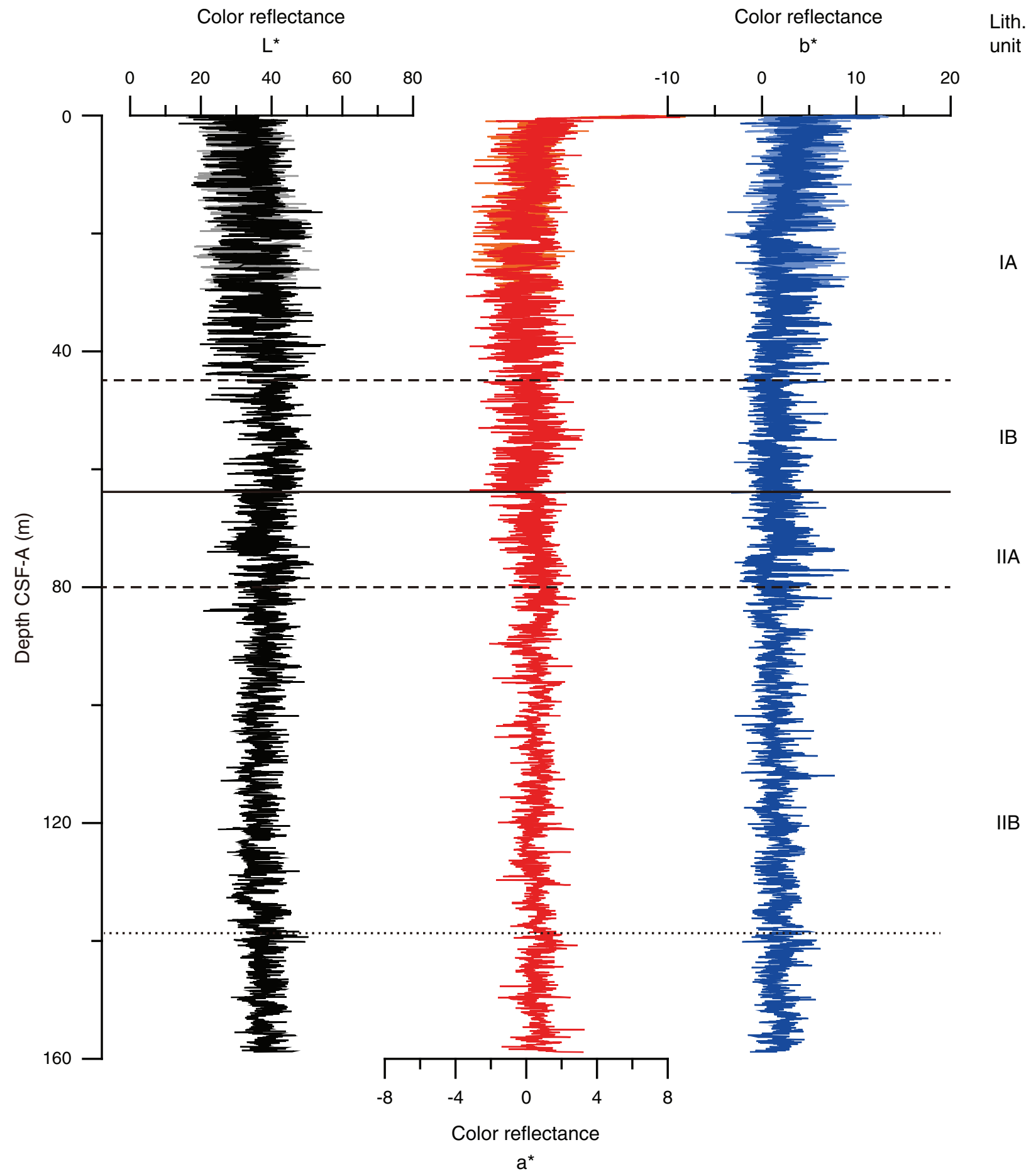


Figure F41. A. Hole U1424A in situ sediment temperature from advanced piston corer temperature tool (APCT-3) measurement for Core 346-U1424A-4H (red square) plotted among in situ sediment temperatures measured at the same location during Leg 127 (Site 794). Black line shows linear fit. B. Bullard plot of heat flow calculated from a linear fit of temperature vs. thermal resistance data. In situ thermal resistances are derived from Site 794 (circles) and U1424 (squares) thermal conductivity laboratory measurements.
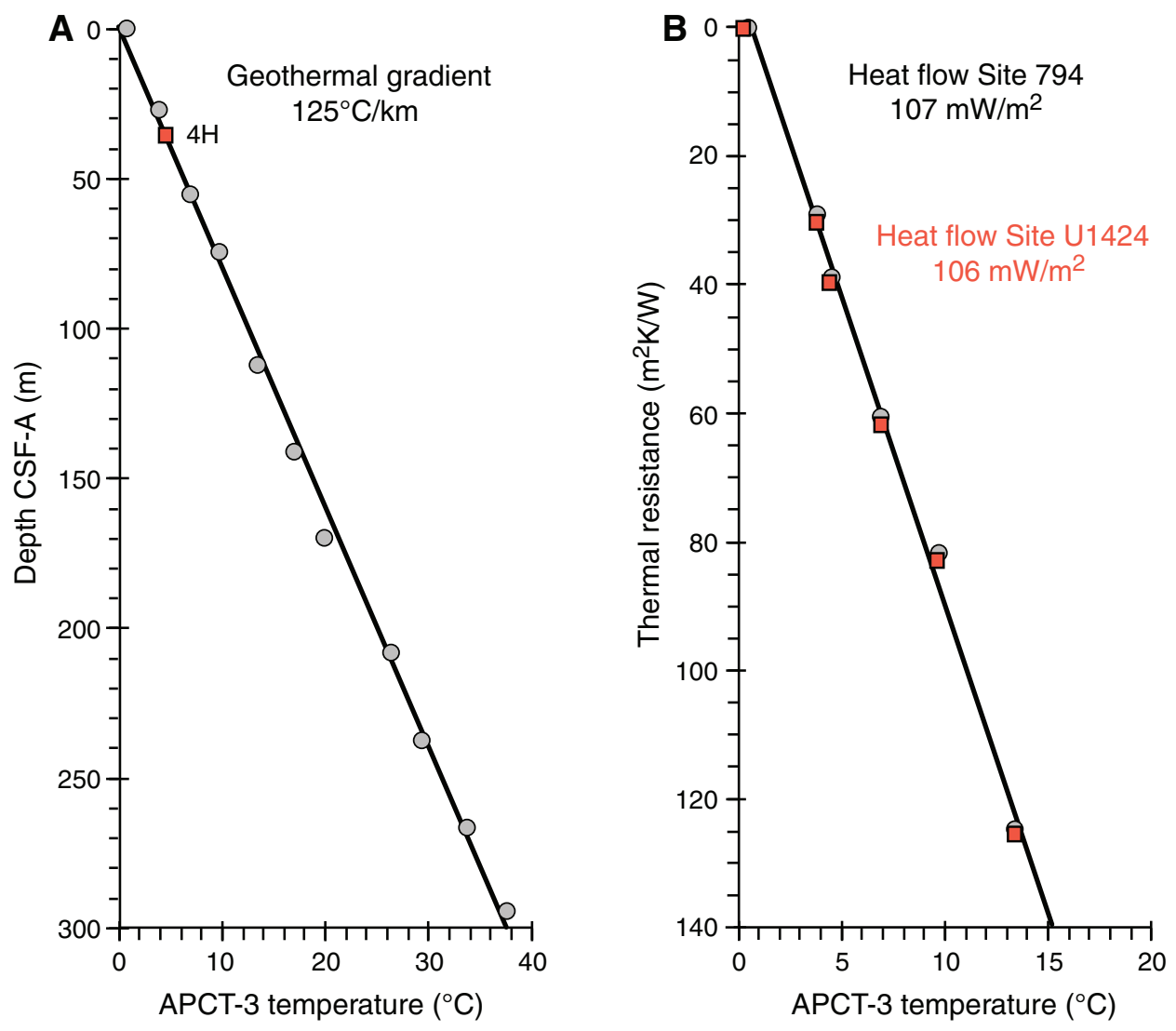
Figure F42. A.-C. Occurrence of ash layers used for correlation between Holes U1424A and U1424B. Width of each core photograph is $7 \mathrm{~cm}$. Brightness and contrast are enhanced from the original images in the LIMS database.

A $\quad 142.7 \mathrm{~m}$ CCSF-A

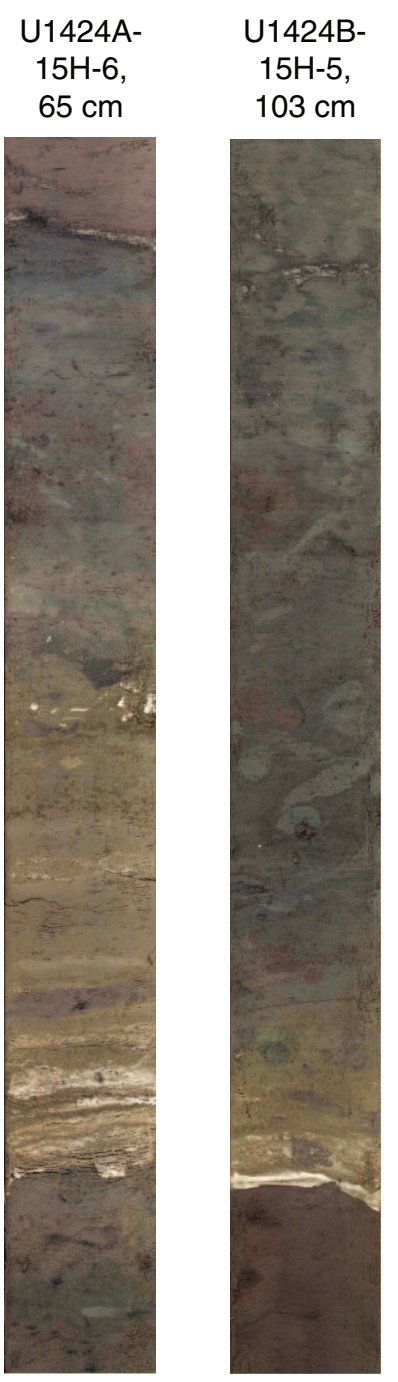

B $\quad 143.2 \mathrm{~m}$ CCSF-A
U1424A-
$15 \mathrm{H}-6$,
$110 \mathrm{~cm}$
$16 \mathrm{H}-1$,
$35 \mathrm{~cm}$

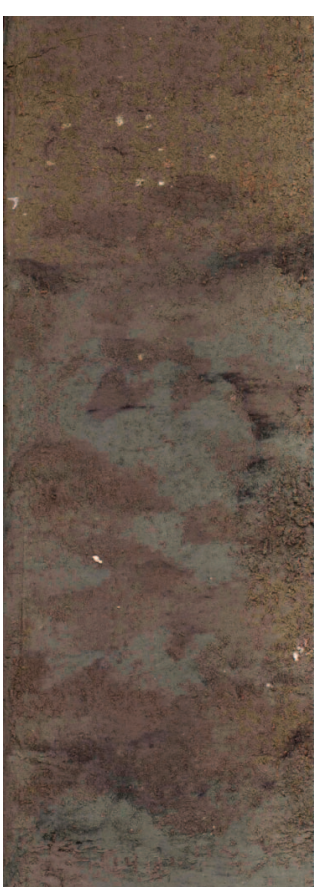

C 149 m CCSF-A

U1424A- U1424B-

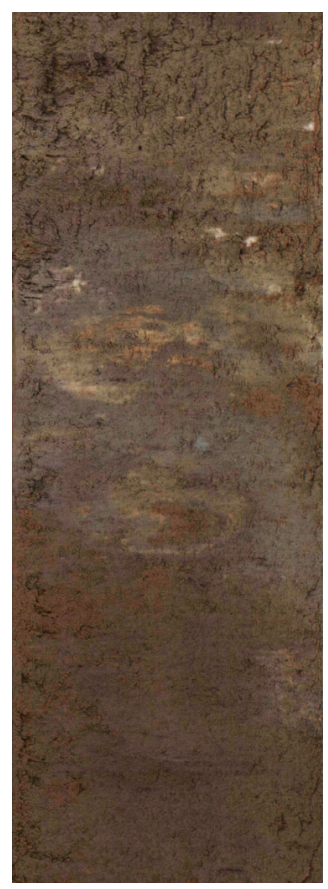

$16 \mathrm{H}-1, \quad 16 \mathrm{H}-5$,

$99 \mathrm{~cm} \quad 28 \mathrm{~cm}$

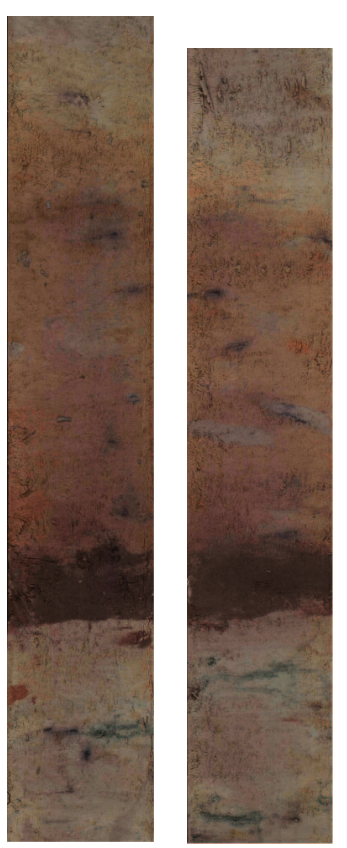


Figure F43. Alignment of all the cores from Holes U1424A (orange), U1424B (blue), and U1424C (red) illustrated using natural gamma radiation (NGR) profiles. Spliced profile is also shown (black).
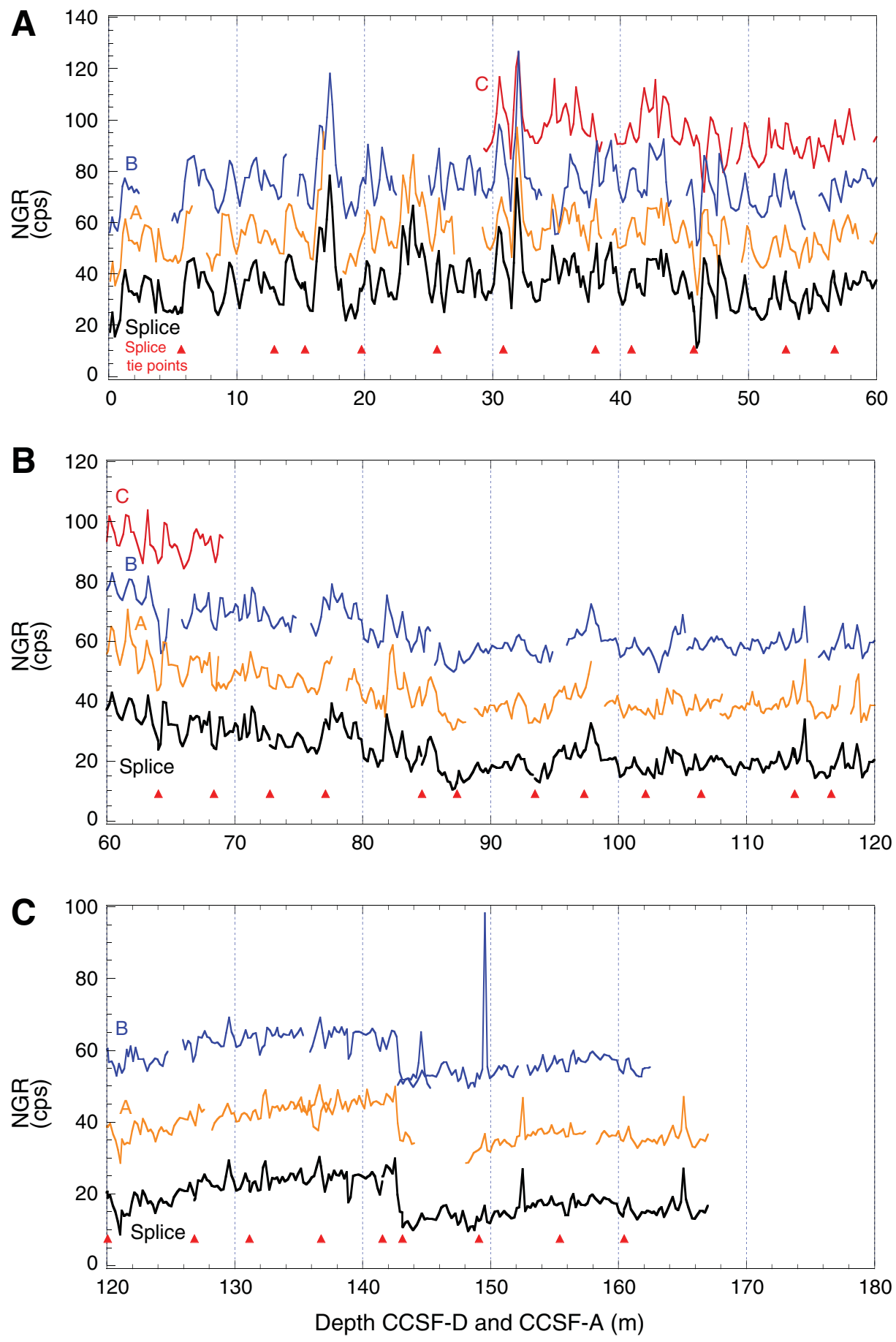
Figure F44. Age model and sedimentation rates, Site U1424. A. Synthesis of biostratigraphic, paleomagnetic, and tephra-based age control points with most likely depth-age relationships used to establish a preliminary age model. B. Average sedimentation rates for each lithologic unit plotted with gamma ray attenuation (GRA) density.

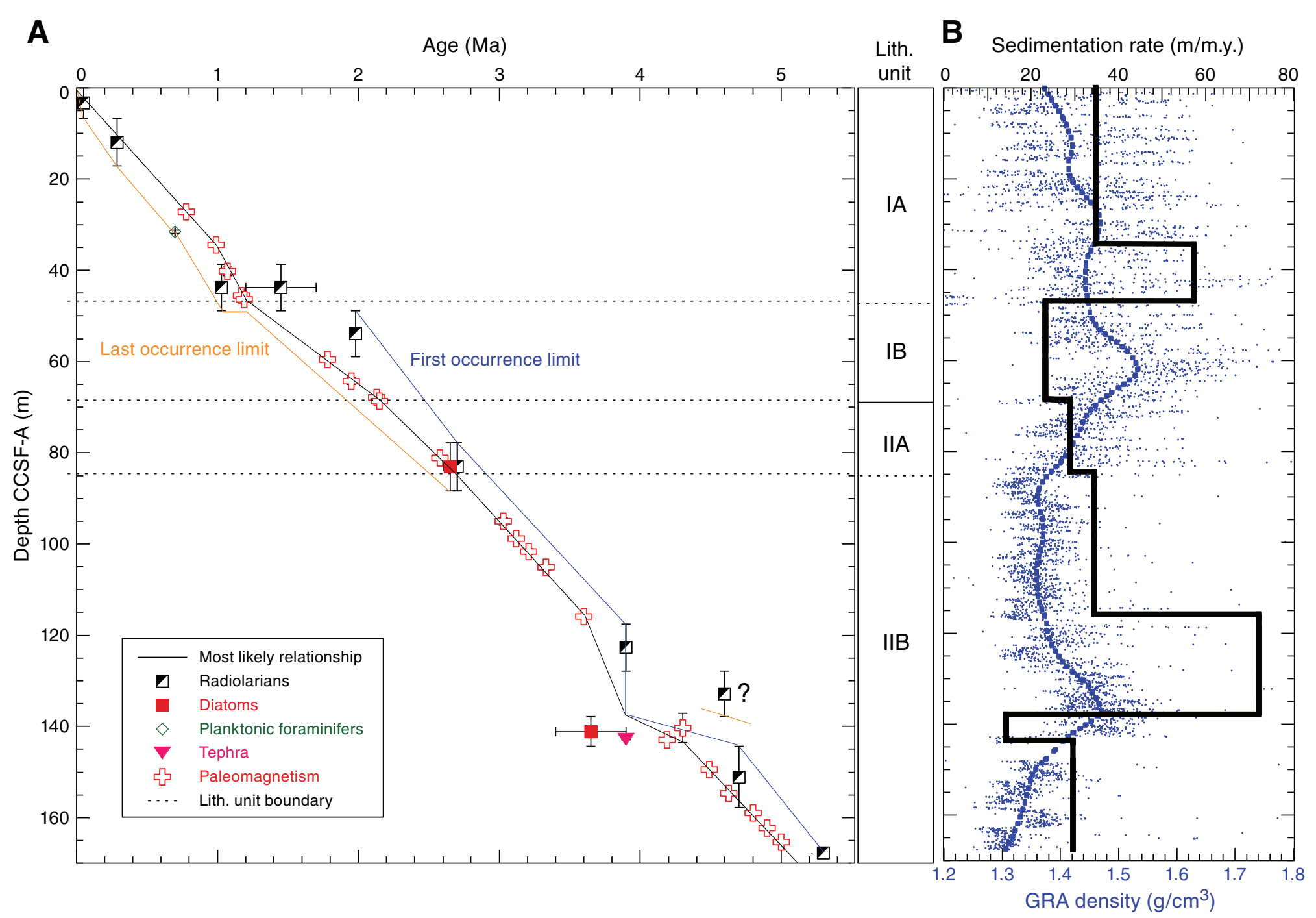


Table T1. Coring summary, Site U1424. (Continued on next page.)

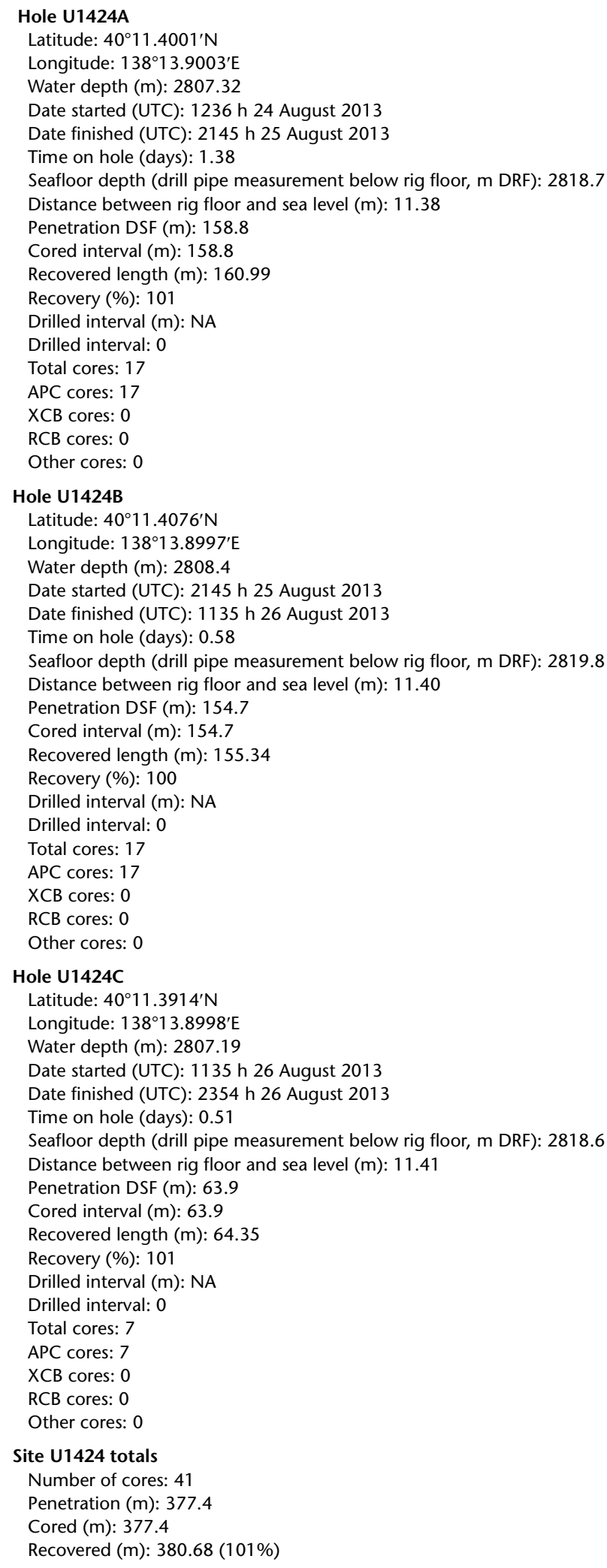


Table T1 (continued).

\begin{tabular}{|c|c|c|c|c|c|c|c|c|c|c|}
\hline Core & $\begin{array}{l}\text { Date } \\
\text { (Aug 2013) }\end{array}$ & $\begin{array}{l}\text { Time } \\
\text { (h) }\end{array}$ & $\begin{array}{l}\text { Top depth } \\
\text { of cored } \\
\text { interval } \\
\text { DSF }(m)\end{array}$ & $\begin{array}{l}\text { Bottom depth } \\
\text { of cored } \\
\text { interval } \\
\text { DSF }(m)\end{array}$ & $\begin{array}{l}\text { Interval } \\
\text { advanced } \\
(\mathrm{m})\end{array}$ & $\begin{array}{l}\text { Top depth } \\
\text { of recovered } \\
\text { core } \\
\text { CSF }(m)\end{array}$ & $\begin{array}{c}\text { Bottom depth } \\
\text { of recovered } \\
\text { core } \\
\text { CSF }(m)\end{array}$ & $\begin{array}{l}\text { Length } \\
\text { of core } \\
\text { recovered } \\
\text { (m) }\end{array}$ & $\begin{array}{l}\text { Curated } \\
\text { length } \\
\text { (m) }\end{array}$ & $\begin{array}{l}\text { Recovery } \\
\text { (\%) }\end{array}$ \\
\hline \multicolumn{11}{|c|}{ 346-U1424A- } \\
\hline $1 \mathrm{H}$ & 25 & 0635 & 0.0 & 6.8 & 6.8 & 0.0 & 6.80 & 6.80 & 6.80 & 100 \\
\hline $2 \mathrm{H}$ & 25 & 0730 & 6.8 & 16.3 & 9.5 & 6.8 & 16.45 & 9.65 & 9.65 & 102 \\
\hline $3 \mathrm{H}$ & 25 & 0815 & 16.3 & 25.8 & 9.5 & 16.3 & 25.28 & 8.98 & 8.98 & 95 \\
\hline $4 \mathrm{H}$ & 25 & 0920 & 25.8 & 35.3 & 9.5 & 25.8 & 35.48 & 9.68 & 9.68 & 102 \\
\hline $5 \mathrm{H}$ & 25 & 1010 & 35.3 & 44.8 & 9.5 & 35.3 & 44.92 & 9.62 & 9.62 & 101 \\
\hline $6 \mathrm{H}$ & 25 & 1055 & 44.8 & 54.3 & 9.5 & 44.8 & 54.39 & 9.59 & 9.59 & 101 \\
\hline $7 \mathrm{H}$ & 25 & 1140 & 54.3 & 63.8 & 9.5 & 54.3 & 64.02 & 9.72 & 9.72 & 102 \\
\hline $8 \mathrm{H}$ & 25 & 1225 & 63.8 & 73.3 & 9.5 & 63.8 & 73.22 & 9.42 & 9.42 & 99 \\
\hline $9 \mathrm{H}$ & 25 & 1315 & 73.3 & 82.8 & 9.5 & 73.3 & 83.03 & 9.73 & 9.73 & 102 \\
\hline $10 \mathrm{H}$ & 25 & 1405 & 82.8 & 92.3 & 9.5 & 82.8 & 92.42 & 9.62 & 9.62 & 101 \\
\hline $11 \mathrm{H}$ & 25 & 1450 & 92.3 & 101.8 & 9.5 & 92.3 & 101.87 & 9.57 & 9.57 & 101 \\
\hline $12 \mathrm{H}$ & 25 & 1540 & 101.8 & 111.3 & 9.5 & 101.8 & 111.53 & 9.73 & 9.73 & 102 \\
\hline $13 \mathrm{H}$ & 25 & 1630 & 111.3 & 120.8 & 9.5 & 111.3 & 121.12 & 9.82 & 9.82 & 103 \\
\hline $14 \mathrm{H}$ & 25 & 1720 & 120.8 & 130.3 & 9.5 & 120.8 & 130.55 & 9.75 & 9.75 & 103 \\
\hline $15 \mathrm{H}$ & 25 & 1845 & 130.3 & 139.8 & 9.5 & 130.3 & 140.20 & 9.90 & 9.90 & 104 \\
\hline $16 \mathrm{H}$ & 25 & 1945 & 139.8 & 149.3 & 9.5 & 139.8 & 149.64 & 9.84 & 9.84 & 104 \\
\hline \multirow[t]{2}{*}{$17 \mathrm{H}$} & 25 & 2040 & 149.3 & 158.8 & 9.5 & 149.3 & 158.87 & 9.57 & 9.57 & 101 \\
\hline & & & \multicolumn{2}{|c|}{ Total advanced $(\mathrm{m})$ : } & 158.8 & \multicolumn{2}{|c|}{ Total recovered $(\mathrm{m})$ : } & 160.99 & & \\
\hline \multicolumn{11}{|c|}{ 346-U1424B- } \\
\hline $1 \mathrm{H}$ & 25 & 2255 & 0.0 & 2.7 & 2.7 & 0.0 & 2.67 & 2.67 & 2.67 & 99 \\
\hline $2 \mathrm{H}$ & 25 & 2330 & 2.7 & 12.2 & 9.5 & 2.7 & 11.97 & 9.27 & 9.27 & 98 \\
\hline $3 \mathrm{H}$ & 26 & 0005 & 12.2 & 21.7 & 9.5 & 12.2 & 20.19 & 7.99 & 7.99 & 84 \\
\hline $4 \mathrm{H}$ & 26 & 0045 & 21.7 & 31.2 & 9.5 & 21.7 & 30.93 & 9.23 & 9.23 & 97 \\
\hline $5 \mathrm{H}$ & 26 & 0120 & 31.2 & 40.7 & 9.5 & 31.2 & 40.85 & 9.65 & 9.65 & 102 \\
\hline $6 \mathrm{H}$ & 26 & 0200 & 40.7 & 50.2 & 9.5 & 40.7 & 50.26 & 9.56 & 9.56 & 101 \\
\hline $7 \mathrm{H}$ & 26 & 0245 & 50.2 & 59.7 & 9.5 & 50.2 & 59.85 & 9.65 & 9.65 & 102 \\
\hline $8 \mathrm{H}$ & 26 & 0320 & 59.7 & 69.2 & 9.5 & 59.7 & 68.98 & 9.28 & 9.28 & 98 \\
\hline $9 \mathrm{H}$ & 26 & 0400 & 69.2 & 78.7 & 9.5 & 69.2 & 78.91 & 9.71 & 9.71 & 102 \\
\hline $10 \mathrm{H}$ & 26 & 0440 & 78.7 & 88.2 & 9.5 & 78.7 & 88.40 & 9.70 & 9.70 & 102 \\
\hline $11 \mathrm{H}$ & 26 & 0520 & 88.2 & 97.7 & 9.5 & 88.2 & 97.86 & 9.66 & 9.66 & 102 \\
\hline $12 \mathrm{H}$ & 26 & 0605 & 97.7 & 107.2 & 9.5 & 97.7 & 107.51 & 9.81 & 9.81 & 103 \\
\hline $13 \mathrm{H}$ & 26 & 0650 & 107.2 & 116.7 & 9.5 & 107.2 & 117.02 & 9.82 & 9.82 & 103 \\
\hline $14 \mathrm{H}$ & 26 & 0730 & 116.7 & 126.2 & 9.5 & 116.7 & 126.54 & 9.84 & 9.84 & 104 \\
\hline $15 \mathrm{H}$ & 26 & 0845 & 126.2 & 135.7 & 9.5 & 126.2 & 135.94 & 9.74 & 9.74 & 103 \\
\hline $16 \mathrm{H}$ & 26 & 0955 & 135.7 & 145.2 & 9.5 & 135.7 & 145.58 & 9.88 & 9.88 & 104 \\
\hline \multirow[t]{2}{*}{$17 \mathrm{H}$} & 26 & 1035 & 145.2 & 154.7 & 9.5 & 145.2 & 155.08 & 9.88 & 9.88 & 104 \\
\hline & & & \multicolumn{2}{|c|}{ Total advanced $(\mathrm{m})$ : } & 154.7 & \multicolumn{2}{|c|}{ Total recovered $(\mathrm{m})$ : } & 155.34 & & \\
\hline \multicolumn{11}{|c|}{ 346-U1424C- } \\
\hline $1 \mathrm{H}$ & 26 & 1250 & 0.0 & 6.9 & 6.9 & 0.0 & 6.92 & 6.92 & 6.92 & 100 \\
\hline $2 \mathrm{H}$ & 26 & 1320 & 6.9 & 16.4 & 9.5 & 6.9 & 16.56 & 9.66 & 9.66 & 102 \\
\hline $3 \mathrm{H}$ & 26 & 1400 & 16.4 & 25.9 & 9.5 & 16.4 & 26.25 & 9.85 & 9.85 & 104 \\
\hline $4 \mathrm{H}$ & 26 & 1440 & 25.9 & 35.4 & 9.5 & 25.9 & 35.28 & 9.38 & 9.38 & 99 \\
\hline $5 \mathrm{H}$ & 26 & 1520 & 35.4 & 44.9 & 9.5 & 35.4 & 44.73 & 9.33 & 9.33 & 98 \\
\hline $6 \mathrm{H}$ & 26 & 1600 & 44.9 & 54.4 & 9.5 & 44.9 & 54.49 & 9.59 & 9.59 & 101 \\
\hline \multirow[t]{2}{*}{$7 \mathrm{H}$} & 26 & 1640 & 54.4 & 63.9 & 9.5 & 54.4 & 64.02 & 9.62 & 9.62 & 101 \\
\hline & & & \multicolumn{2}{|c|}{ Total advanced $(\mathrm{m})$} & 80.5 & \multicolumn{2}{|c|}{ Total recovered $(\mathrm{m})$ : } & 59.07 & & \\
\hline
\end{tabular}

$\mathrm{DRF}=$ drilling depth below rig floor, $\mathrm{DSF}=$ drilling depth below seafloor, $\mathrm{CSF}=$ core depth below seafloor. $\mathrm{APC}=\mathrm{advanced}$ piston corer, $\mathrm{XCB}=$ extended core barrel, $\mathrm{RCB}=$ rotary core barrel. $\mathrm{H}=\mathrm{APC}$ system. $\mathrm{NA}=$ not applicable. 
Table T2. XRD analysis of bulk samples, Site U1424.

\begin{tabular}{|c|c|c|c|c|c|c|c|c|c|c|c|}
\hline $\begin{array}{l}\text { Core section, } \\
\text { interval }(\mathrm{cm})\end{array}$ & $\begin{array}{l}\text { Top depth } \\
\text { CSF-A (m) }\end{array}$ & $\begin{array}{l}\text { Smectite } \\
\text { (counts) }\end{array}$ & $\begin{array}{c}\text { Illite } \\
\text { (counts) }\end{array}$ & $\begin{array}{l}\text { Kaolinite } \\
+ \text { chlorite } \\
\text { (counts) }\end{array}$ & $\begin{array}{l}\text { Opal-A } \\
\text { (counts) }\end{array}$ & $\begin{array}{l}\text { Quartz } \\
\text { (counts) }\end{array}$ & $\begin{array}{c}\text { K-feldspar } \\
\text { (counts) }\end{array}$ & $\begin{array}{l}\text { Plagioclase } \\
\text { (counts) }\end{array}$ & $\begin{array}{c}\text { Calcite } \\
\text { (counts) }\end{array}$ & $\begin{array}{l}\text { Halite } \\
\text { (counts) }\end{array}$ & $\begin{array}{l}\text { Pyrite } \\
\text { (counts) }\end{array}$ \\
\hline \multicolumn{12}{|l|}{ 346-U1424A- } \\
\hline $1 \mathrm{H}-2,81.0-82.0$ & 2.31 & 223 & 579 & 429 & 17 & 5942 & 232 & 775 & 0 & 288 & 0 \\
\hline $2 \mathrm{H}-1,126.0-127.0$ & 8.06 & 275 & 690 & 466 & 10 & 4870 & 227 & 739 & 0 & 328 & 0 \\
\hline $3 \mathrm{H}-1,56.0-57.0$ & 16.86 & 211 & 315 & 211 & 47 & 3184 & 275 & 428 & 0 & 505 & 130 \\
\hline $3 \mathrm{H}-3,126.0-127.0$ & 20.56 & 129 & 127 & 108 & 25 & 1618 & 419 & 531 & 0 & 148 & 690 \\
\hline $4 \mathrm{H}-1,103.0-104.0$ & 26.83 & 179 & 268 & 166 & 29 & 3740 & 230 & 549 & 0 & 291 & 50 \\
\hline $5 \mathrm{H}-1,29.0-30.0$ & 35.59 & 278 & 654 & 403 & -16 & 4893 & 760 & 689 & 0 & 268 & 0 \\
\hline 7H-1, 109.0-110.0 & 55.39 & 263 & 452 & 255 & 19 & 4046 & 245 & 621 & 0 & 176 & 0 \\
\hline $8 \mathrm{H}-2,133.0-134.0$ & 66.63 & 236 & 616 & 422 & 20 & 4847 & 212 & 694 & 0 & 148 & 0 \\
\hline $9 \mathrm{H}-2,9.0-10.0$ & 74.89 & 135 & 275 & 185 & 64 & 3490 & 198 & 606 & 0 & 401 & 94 \\
\hline $10 \mathrm{H}-1,53.0-54.0$ & 83.33 & 89 & 285 & 164 & 91 & 2870 & 170 & 394 & 0 & 459 & 89 \\
\hline $10 \mathrm{H}-1,101.0-102.0$ & 83.81 & 200 & 93 & 0 & 0 & 723 & 0 & 185 & 1560 & 373 & 0 \\
\hline $11 \mathrm{H}-1,68.0-69.0$ & 92.98 & 147 & 301 & 170 & 33 & 3576 & 180 & 518 & 0 & 397 & 108 \\
\hline $12 \mathrm{H}-1,93.0-94.0$ & 102.73 & 164 & 314 & 169 & 108 & 3328 & 193 & 493 & 0 & 459 & 98 \\
\hline $13 \mathrm{H}-1,100.0-101.0$ & 112.30 & 140 & 174 & 156 & 181 & 1922 & 180 & 294 & 0 & 490 & 139 \\
\hline $13 \mathrm{H}-5,23.0-24.0$ & 117.41 & 73 & 0 & 0 & 0 & 127 & 0 & 0 & 1258 & 0 & 0 \\
\hline $13 \mathrm{H}-5,25.0-26.0$ & 117.43 & 80 & 0 & 0 & 0 & 118 & 0 & 0 & 1352 & 0 & 0 \\
\hline $13 \mathrm{H}-6,3.0-4.0$ & 118.66 & 89 & 0 & 0 & 132 & 1869 & 0 & 1019 & 531 & 361 & 106 \\
\hline $14 \mathrm{H}-1,91.0-92.0$ & 121.71 & 314 & 442 & 347 & 52 & 3871 & 0 & 684 & 0 & 321 & 73 \\
\hline $15 \mathrm{H}-1,40.0-41.0$ & 130.70 & 406 & 338 & 438 & 30 & 4035 & 0 & 608 & 0 & 328 & 84 \\
\hline $16 \mathrm{H}-1,97.0-98.0$ & 140.77 & 71 & 0 & 0 & 69 & 68 & 695 & 613 & 0 & 113 & 201 \\
\hline $16 \mathrm{H}-1,118.0-119.0$ & 140.98 & 103 & 183 & 136 & 129 & 1912 & 158 & 299 & 0 & 484 & 124 \\
\hline $17 \mathrm{H}-2,72.0-73.0$ & 151.52 & 106 & 189 & 138 & 161 & 1972 & 126 & 277 & 0 & 450 & 140 \\
\hline
\end{tabular}


Table T3. Visible tephra layers thicker than $0.5 \mathrm{~cm}$, Hole U1424A.

\begin{tabular}{|c|c|c|c|}
\hline $\begin{array}{l}\text { Core, section, } \\
\text { interval }(\mathrm{cm})\end{array}$ & $\begin{array}{l}\text { Thickness } \\
(\mathrm{cm})\end{array}$ & Color & Occurrence \\
\hline \multicolumn{4}{|l|}{ 346-U1424A- } \\
\hline $1 \mathrm{H}-1,132-135.5$ & 3.5 & Gray & Layered \\
\hline $1 \mathrm{H}-2,101-102$ & 1.0 & Light gray & Layered \\
\hline $1 \mathrm{H}-3,94.5-98$ & 3.5 & Light gray & Layered \\
\hline $1 \mathrm{H}-3,107-108$ & 1.0 & Dark gray & Layered \\
\hline $1 \mathrm{H}-4,25.8-26.3$ & 0.5 & Light gray & Layered \\
\hline $1 \mathrm{H}-5,4.2-5$ & 0.8 & Gray & Layered \\
\hline $2 \mathrm{H}-1,96.5-98$ & 1.5 & Gray & Layered \\
\hline $2 \mathrm{H}-2,7.2-8.7$ & 1.5 & Dark gray & Layered \\
\hline $2 \mathrm{H}-4,0-2.5$ & 2.5 & Brownish gray & Layered \\
\hline $2 \mathrm{H}-6,116-117$ & 1.0 & Light gray & Layered \\
\hline $2 \mathrm{H}-7,14.8-15.4$ & 0.6 & Gray & Layered \\
\hline $2 \mathrm{H}-7,33-36$ & 3.0 & Light gray & Layered \\
\hline $3 \mathrm{H}-1,51-52$ & 1.0 & Light gray & Layered \\
\hline $3 \mathrm{H}-1,86.8-87.6$ & 0.8 & Light gray & Layered \\
\hline $3 \mathrm{H}-1,89.5-90.3$ & 0.8 & Light gray & Layered \\
\hline $3 \mathrm{H}-1,119-120$ & 1.0 & Light gray & Layered \\
\hline $3 \mathrm{H}-1,104.2-105.5$ & 1.3 & Gray & Layered \\
\hline $3 \mathrm{H}-1,107-107.5$ & 0.5 & Gray & Layered \\
\hline $3 \mathrm{H}-5,26.3-27$ & 0.7 & White & Layered \\
\hline $3 \mathrm{H}-5,47.1-47.6$ & 0.5 & Light gray & Layered \\
\hline $3 \mathrm{H}-5,69-69.8$ & 0.8 & Light gray & Layered \\
\hline $3 \mathrm{H}-5,121-123.5$ & 2.5 & White & Layered \\
\hline $3 \mathrm{H}-6,54-56$ & 2.0 & Light gray & Layered \\
\hline $3 \mathrm{H}-6,83.6-84.1$ & 0.5 & Black & Layered \\
\hline $3 \mathrm{H}-6,122-123$ & 1.0 & Dark gray & Layered \\
\hline $4 \mathrm{H}-1,78$ & 1.0 & White & Layered \\
\hline $4 \mathrm{H}-1,134-135$ & 1.0 & White & Layered \\
\hline $4 \mathrm{H}-1,120.5-121$ & 0.5 & Dark gray & Layered \\
\hline $4 \mathrm{H}-1,5-5.5$ & 0.5 & Light gray & Layered \\
\hline $4 \mathrm{H}-4,27-28$ & 1.0 & Light gray & Layered \\
\hline $4 \mathrm{H}-4,116.5-118.5$ & 2.0 & Light gray & Layered \\
\hline $4 \mathrm{H}-4,129.2-129.7$ & 0.5 & Gray & Layered \\
\hline $4 \mathrm{H}-5,8-8.5$ & 0.5 & White & Layered \\
\hline $4 \mathrm{H}-5,21.2-24$ & 2.8 & Dark gray & Layered \\
\hline $4 \mathrm{H}-5,16.5-109$ & 2.5 & Gray & Layered \\
\hline $4 \mathrm{H}-5,120.2-120.7$ & 0.5 & White & Layered \\
\hline $4 \mathrm{H}-5,149.7-152$ & 2.3 & White & Layered \\
\hline $4 \mathrm{H}-6,12-13$ & 1.0 & White & Layered \\
\hline $4 \mathrm{H}-6,17.5-19$ & 1.5 & White & Layered \\
\hline $4 \mathrm{H}-6,53.5-55$ & 1.5 & White & Layered \\
\hline $4 \mathrm{H}-7,30.5-31.5$ & 1.0 & Light gray & Layered \\
\hline $5 \mathrm{H}-1,60.2-60.7$ & 0.5 & White & Layered \\
\hline $5 \mathrm{H}-2,39-39.5$ & 0.5 & Light gray & Layered \\
\hline $5 \mathrm{H}-2,72-76.3$ & 4.3 & White & Layered \\
\hline $5 \mathrm{H}-3,18-18.8$ & 0.8 & White & Layered \\
\hline $5 \mathrm{H}-3,31-32$ & 1.0 & White & Layered \\
\hline $5 \mathrm{H}-3,58-62$ & 4.0 & White & Layered \\
\hline $5 \mathrm{H}-3,82.5-88.5$ & 6.0 & White & Layered \\
\hline $5 \mathrm{H}-4,56.2-57.8$ & 1.6 & White & Layered \\
\hline $5 \mathrm{H}-4,126.5-127$ & 0.5 & Light gray & Layered \\
\hline $5 \mathrm{H}-5,57.5-59.6$ & 2.1 & Gray & Layered \\
\hline
\end{tabular}

\begin{tabular}{|c|c|c|c|}
\hline $\begin{array}{l}\text { Core, section, } \\
\text { interval }(\mathrm{cm})\end{array}$ & $\begin{array}{l}\text { Thickness } \\
(\mathrm{cm})\end{array}$ & Color & Occurrence \\
\hline $5 \mathrm{H}-5,109-110$ & 1.0 & White & Layered \\
\hline $5 \mathrm{H}-6,99.5-100.2$ & 0.5 & White & Layered \\
\hline $5 \mathrm{H}-6,100.5-112.5$ & 12.0 & Light gray & Layered \\
\hline $6 \mathrm{H}-2,109.5-110.8$ & 1.3 & White & Layered \\
\hline $6 \mathrm{H}-3,112.5-113$ & 0.5 & White & Layered \\
\hline $6 \mathrm{H}-5,97.3-98.3$ & 1.0 & Greenish gray & Layered \\
\hline $6 \mathrm{H}-5,104.5-105$ & 0.5 & Light gray & Layered \\
\hline $6 \mathrm{H}-5,121.5-123$ & 1.5 & Dark gray & Layered \\
\hline $6 \mathrm{H}-6,42.5-43$ & 0.5 & Gray & Layered \\
\hline $6 \mathrm{H}-6,103-103.5$ & 0.5 & White & Layered \\
\hline $6 \mathrm{H}-7,49.5-53.5$ & 4.0 & White & Layered \\
\hline $7 \mathrm{H}-1,4-10$ & 6.0 & Light gray & Layered \\
\hline 7H- $1,19-21.5$ & 2.5 & Light gray & Layered \\
\hline $7 \mathrm{H}-1,41.5-42$ & 0.5 & Light gray & Layered \\
\hline $7 \mathrm{H}-1,49.8-51$ & 1.2 & Gray & Layered \\
\hline $7 \mathrm{H}-1,74.5-75$ & 0.5 & Gray & Layered \\
\hline $7 \mathrm{H}-2,5-8.5$ & 3.5 & Light gray & Dispersed \\
\hline $7 \mathrm{H}-2,67.5-70$ & 2.5 & Light gray & Layered \\
\hline $7 \mathrm{H}-2,22.5-23.5$ & 1.0 & Light gray & Layered \\
\hline 7H-4, 21-24.5 & 3.5 & Black & Layered \\
\hline $8 \mathrm{H}-5,31.3-32$ & 0.7 & Light brownish gray & Layered \\
\hline $8 \mathrm{H}-5,55.4-56$ & 0.6 & White & Layered \\
\hline $8 \mathrm{H}-5,45.5-46.8$ & 1.3 & Black & Layered \\
\hline $9 \mathrm{H}-1,63-66$ & 3.0 & White & Layered \\
\hline $9 \mathrm{H}-1,97-98.2$ & 1.2 & Black & Layered \\
\hline $9 \mathrm{H}-2,100.3-101.5$ & 1.2 & Dark gray & Layered \\
\hline $9 \mathrm{H}-2,120.5-121.5$ & 1.0 & Light brownish gray & Layered \\
\hline $9 \mathrm{H}-2,144-146$ & 2.0 & Dark gray & Layered \\
\hline $9 \mathrm{H}-3,126.5-127.5$ & 1.0 & White & Layered \\
\hline $9 \mathrm{H}-4,10.5-12$ & 1.5 & Light brownish gray & Layered \\
\hline $10 \mathrm{H}-4,96-97$ & 1.0 & White & Layered \\
\hline $11 \mathrm{H}-3,1-3$ & 0.7 & Light gray & Patched \\
\hline $11 \mathrm{H}-4,22-24$ & 1.0 & Light gray & Layered \\
\hline $11 \mathrm{H}-5,20-23$ & 3.0 & Light gray & Layered \\
\hline $11 \mathrm{H}-6,24-26$ & 0.7 & Brownish gray & Patched \\
\hline $12 \mathrm{H}-4,135-137$ & 2.0 & Dark gray & Layered \\
\hline $12 \mathrm{H}-5,69-79$ & 3.0 & White & Patched \\
\hline $13 \mathrm{H}-4,31-35$ & 4.0 & White & Layered \\
\hline $13 \mathrm{H}-6,143-158$ & 15.0 & Gray & Layered \\
\hline $14 \mathrm{H}-3,138-146$ & 1.0 & Light gray & Patched \\
\hline $15 \mathrm{H}-2,135-137$ & 0.7 & Gray & Patched \\
\hline $15 \mathrm{H}-6,43.5-48$ & 4.5 & White & Layered \\
\hline $15 \mathrm{H}-6,51.5-54$ & 2.5 & White & Layered \\
\hline $15 \mathrm{H}-6,57-66$ & 9.0 & Light brownish gray & Layered \\
\hline $16 \mathrm{H}-1,96-99$ & 3.0 & Dark gray & Layered \\
\hline $16 \mathrm{H}-4,9-13$ & 1.3 & Gray & Patched \\
\hline $17 \mathrm{H}-2,100.5-105.5$ & 5.0 & Dark gray & Layered \\
\hline $17 \mathrm{H}-5,15-22.5$ & 7.5 & Brownish gray & Layered \\
\hline $17 \mathrm{H}-5,91-103.5$ & 12.5 & White & Layered \\
\hline $17 \mathrm{H}-6,126-134$ & 2.7 & White & Dispersed \\
\hline
\end{tabular}


Table T4. Microfossil bioevents, Site U1424.

\begin{tabular}{|c|c|c|c|c|c|c|c|c|c|c|c|c|}
\hline \multicolumn{2}{|c|}{ Core, section, interval $(\mathrm{cm})$} & \multirow{2}{*}{$\begin{array}{l}\text { Event } \\
\text { type }\end{array}$} & \multirow[b]{2}{*}{ Bioevents and epoch boundaries } & \multirow{2}{*}{$\begin{array}{l}\text { Age } \\
\text { (Ma) }\end{array}$} & \multicolumn{4}{|c|}{ Depth CSF-A (m) } & \multicolumn{4}{|c|}{ Depth CCSF-A (m) } \\
\hline Top & Bottom & & & & Top & Bottom & Midpoint & \pm & Top & Bottom & Midpoint & \pm \\
\hline 346-U1424A- 3 & 346-U1424A- & & & & & & & & & & & \\
\hline NA & $1 \mathrm{H}-\mathrm{CC}$ & $\mathrm{R}$ & LO Lychnocanoma sakaii & 0.05 & 0 & 6.75 & 3.38 & 3.38 & 0.00 & 6.75 & 3.38 & 3.38 \\
\hline $1 \mathrm{H}-\mathrm{CC}$ & $2 \mathrm{H}-\mathrm{CC}$ & $\mathrm{R}$ & LO Spongodiscus sp. & 0.29 & 6.75 & 16.40 & 11.58 & 4.83 & 6.75 & 17.17 & 11.96 & 5.21 \\
\hline $4 \mathrm{H}-2 \mathrm{~W}, 58-59$ & $4 \mathrm{H}-2 \mathrm{~W}, 135-136$ & PF & LO Neogloboquadrina kagaensis group & 0.70 & 27.88 & 28.65 & 28.27 & 0.38 & 31.18 & 31.95 & 31.57 & 0.39 \\
\hline $5 \mathrm{H}-\mathrm{CC}$ & $5 \mathrm{H}-\mathrm{CC}$ & $\mathrm{R}$ & FO and LO Eucyrtidium matuyamai & $1.03-1.98$ & 44.87 & 44.87 & 44.87 & 0.00 & 48.87 & 48.87 & 48.87 & 5.00 \\
\hline $4 \mathrm{H}-\mathrm{CC}$ & $5 \mathrm{H}-\mathrm{CC}$ & $\mathrm{R}$ & LO Axoprunum acquilonium & $1.2-1.7$ & 35.43 & 44.87 & 40.15 & 4.72 & 38.73 & 48.87 & 43.80 & 5.07 \\
\hline \multicolumn{2}{|c|}{ Pliocene/Pleistocene boundary } & & & 2.59 & & & & & & & & \\
\hline $8 \mathrm{H}-\mathrm{CC}$ & $9 \mathrm{H}-\mathrm{CC}$ & D & LO Neodenticula kamtschatica & $2.6-2.7$ & 73.17 & 82.98 & 78.08 & 4.91 & 77.79 & 88.32 & 83.06 & 5.27 \\
\hline $8 \mathrm{H}-\mathrm{CC}$ & 9H-CC & $\mathrm{R}$ & FO Cycladophora davisiana & 2.7 & 73.17 & 82.98 & 78.08 & 4.91 & 77.79 & 88.32 & 83.06 & 5.27 \\
\hline $8 \mathrm{H}-\mathrm{CC}$ & $9 \mathrm{H}-\mathrm{CC}$ & $\mathrm{R}$ & LO Hexacontium parviakitaensis & 2.7 & 73.17 & 82.98 & 78.08 & 4.91 & 77.79 & 88.32 & 83.06 & 5.27 \\
\hline $12 \mathrm{H}-\mathrm{CC}$ & $13 \mathrm{H}-\mathrm{CC}$ & $\mathrm{R}$ & FO Hexacontium parviakitaensis & $3.9-4.3$ & 111.48 & 121.07 & 116.28 & 4.79 & 117.53 & 127.85 & 122.69 & 5.16 \\
\hline $13 \mathrm{H}-\mathrm{CC}$ & $14 \mathrm{H}-\mathrm{CC}$ & $\mathrm{R}$ & RD Siphocampe arachnea group & 4.46 & 121.07 & 130.50 & 125.79 & 4.72 & 127.85 & 137.83 & 132.84 & 4.99 \\
\hline $14 \mathrm{H}-\mathrm{CC}$ & $15 \mathrm{H}-\mathrm{CC}$ & D & FO Neodenticula koizumii & $3.4-3.9$ & 130.50 & 140.15 & 135.33 & 4.83 & 137.83 & 144.39 & 141.11 & 3.28 \\
\hline $15 \mathrm{H}-\mathrm{CC}$ & $16 \mathrm{H}-\mathrm{CC}$ & $\mathrm{R}$ & RI Siphocampe arachnea group & 4.7 & 140.15 & 149.59 & 144.87 & 4.72 & 144.39 & 157.75 & 151.07 & 6.68 \\
\hline
\end{tabular}

$\mathrm{R}=$ radiolarian, $\mathrm{PF}=$ planktonic foraminifer, $\mathrm{D}=$ diatom. $\mathrm{LO}=$ last occurrence, $\mathrm{FO}=$ first occurrence, $\mathrm{RD}=$ rapid decrease, $\mathrm{RI}=$ rapid increase. 
Table T5. Preservation and estimated abundance of calcareous nannofossils, Site U1424.

\begin{tabular}{|c|c|c|c|c|c|c|c|c|c|}
\hline $\begin{array}{l}\text { Core, section, } \\
\text { interval }(\mathrm{cm})\end{array}$ & $\begin{array}{c}\text { Top } \\
\text { depth } \\
\text { CSF-A (m) }\end{array}$ & $\begin{array}{c}\text { Bottom } \\
\text { depth } \\
\text { CSF-A (m) }\end{array}$ & 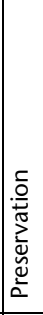 & 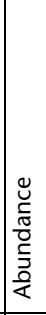 & 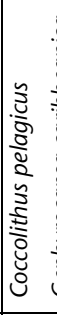 & 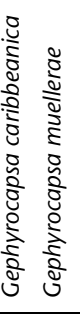 & 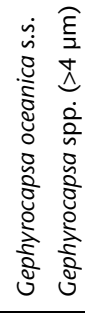 & 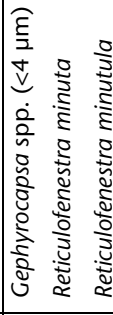 & 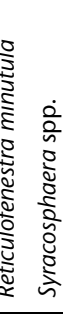 \\
\hline \multicolumn{10}{|l|}{ 346-U1424A- } \\
\hline $1 \mathrm{H}-2,50-51$ & 2.00 & 2.01 & & B & & & & & \\
\hline $1 \mathrm{H}-4,42-43$ & 4.92 & 4.93 & $\mathrm{P}$ & $\mathrm{R}$ & $\mathrm{R}$ & & $\mathrm{R} \quad \mathrm{F}$ & $\mathrm{F}$ & $\mathrm{R}$ \\
\hline $1 \mathrm{H}-5,23-24$ & 6.23 & 6.24 & & B & & & & & \\
\hline $1 \mathrm{H}-\mathrm{CC}$ & 6.75 & 6.80 & & B & & & & & \\
\hline $2 \mathrm{H}-7,45$ & 15.97 & 15.97 & $M$ & A & & & & A D & \\
\hline $2 \mathrm{H}-7,53$ & 16.05 & 16.05 & G & D & & & & D & \\
\hline $2 \mathrm{H}-\mathrm{CC}$ & 16.40 & 16.45 & & B & & & & & \\
\hline $3 \mathrm{H}-3,13-14$ & 19.43 & 19.44 & $M$ & A & $\mathrm{F}$ & & $\mathrm{F}$ & C C & $\mathrm{F}$ \\
\hline $3 \mathrm{H}-3,49-50$ & 19.79 & 19.80 & $M$ & $\mathrm{R}$ & $\mathrm{R}$ & & & & \\
\hline $3 \mathrm{H}-4,96-97$ & 21.76 & 21.77 & $M$ & $\mathrm{R}$ & $\mathrm{R}$ & & & & \\
\hline $3 \mathrm{H}-\mathrm{CC}$ & 25.24 & 25.28 & & B & & & & & \\
\hline $4 \mathrm{H}-2,58-59$ & 27.88 & 27.89 & $M$ & $\mathrm{R}$ & $\mathrm{R}$ & & & $\mathrm{R}$ & \\
\hline $4 \mathrm{H}-2,135-136$ & 28.65 & 28.66 & $M$ & C & $\mathrm{R}$ & $\mathrm{R} \quad \mathrm{R}$ & $\mathrm{R}$ & C C & \\
\hline $4 \mathrm{H}-3,12-13$ & 28.92 & 28.93 & $M$ & A & $R$ & $\mathrm{~F}$ & $\mathrm{~F}$ & A A & \\
\hline $4 \mathrm{H}-5,46-47$ & 32.26 & 32.27 & & B & & & & & \\
\hline $4 \mathrm{H}-5,123-124$ & 33.03 & 33.04 & & B & & & & & \\
\hline $4 \mathrm{H}-\mathrm{CC}$ & 35.43 & 35.48 & & B & & & & & \\
\hline $5 \mathrm{H}-2,116-117$ & 37.96 & 37.97 & & B & & & & & \\
\hline $5 \mathrm{H}-4,76-77$ & 40.56 & 40.57 & & B & & & & & \\
\hline $5 \mathrm{H}-\mathrm{CC}$ & 44.87 & 44.92 & & B & & & & & \\
\hline $6 \mathrm{H}-4,128-129$ & 50.58 & 50.59 & & B & & & & & \\
\hline $6 \mathrm{H}-\mathrm{CC}$ & 54.34 & 54.39 & & B & & & & & \\
\hline $7 \mathrm{H}-1,71-72$ & 55.01 & 55.02 & & B & & & & & \\
\hline $7 \mathrm{H}-7,37-38$ & 63.67 & 63.68 & & B & & & & & \\
\hline $7 \mathrm{H}-\mathrm{CC}$ & 63.97 & 64.02 & & B & & & & & \\
\hline $8 \mathrm{H}-\mathrm{CC}$ & 73.17 & 73.22 & & B & & & & & \\
\hline 9H-CC & 82.98 & 83.03 & & B & & & & & \\
\hline $10 \mathrm{H}-\mathrm{CC}$ & 92.37 & 92.42 & & B & & & & & \\
\hline $11 \mathrm{H}-4,36$ & 96.54 & 96.54 & & B & & & & & \\
\hline $11 \mathrm{H}-7,100$ & 101.68 & 101.68 & & B & & & & & \\
\hline $11 \mathrm{H}-\mathrm{CC}$ & 101.82 & 101.87 & & B & & & & & \\
\hline $12 \mathrm{H}-\mathrm{CC}$ & 111.48 & 111.53 & & B & & & & & \\
\hline $13 \mathrm{H}-\mathrm{CC}$ & 121.07 & 121.12 & & B & & & & & \\
\hline $14 \mathrm{H}-\mathrm{CC}$ & 130.50 & 130.55 & & B & & & & & \\
\hline $15 \mathrm{H}-\mathrm{CC}$ & 140.15 & 140.20 & & B & & & & & \\
\hline $16 \mathrm{H}-\mathrm{CC}$ & 149.59 & 149.64 & & B & & & & & \\
\hline $17 \mathrm{H}-\mathrm{CC}$ & 158.82 & 158.87 & & B & & & & & \\
\hline \multicolumn{10}{|l|}{ 346-U1424B- } \\
\hline $1 \mathrm{H}-\mathrm{CC}$ & 2.62 & 2.67 & & B & & & & & \\
\hline $2 \mathrm{H}-\mathrm{CC}$ & 11.92 & 11.97 & & B & & & & & \\
\hline $3 \mathrm{H}-\mathrm{CC}$ & 20.13 & 20.19 & & B & & & & & \\
\hline $4 \mathrm{H}-\mathrm{CC}$ & 30.88 & 30.93 & & B & & & & & \\
\hline
\end{tabular}

Preservation: $\mathrm{G}=$ good, $\mathrm{M}=$ moderate, $\mathrm{P}=$ poor. Abundance: $\mathrm{D}=$ dominant, $\mathrm{A}=$ abundant $\mathrm{C}=$ common, $\mathrm{F}=$ few, $\mathrm{R}=$ rare, $\mathrm{B}=$ barren. Shaded intervals = barren. 
Table T6. Preservation and estimated abundance of radiolarians, Hole U1424A.

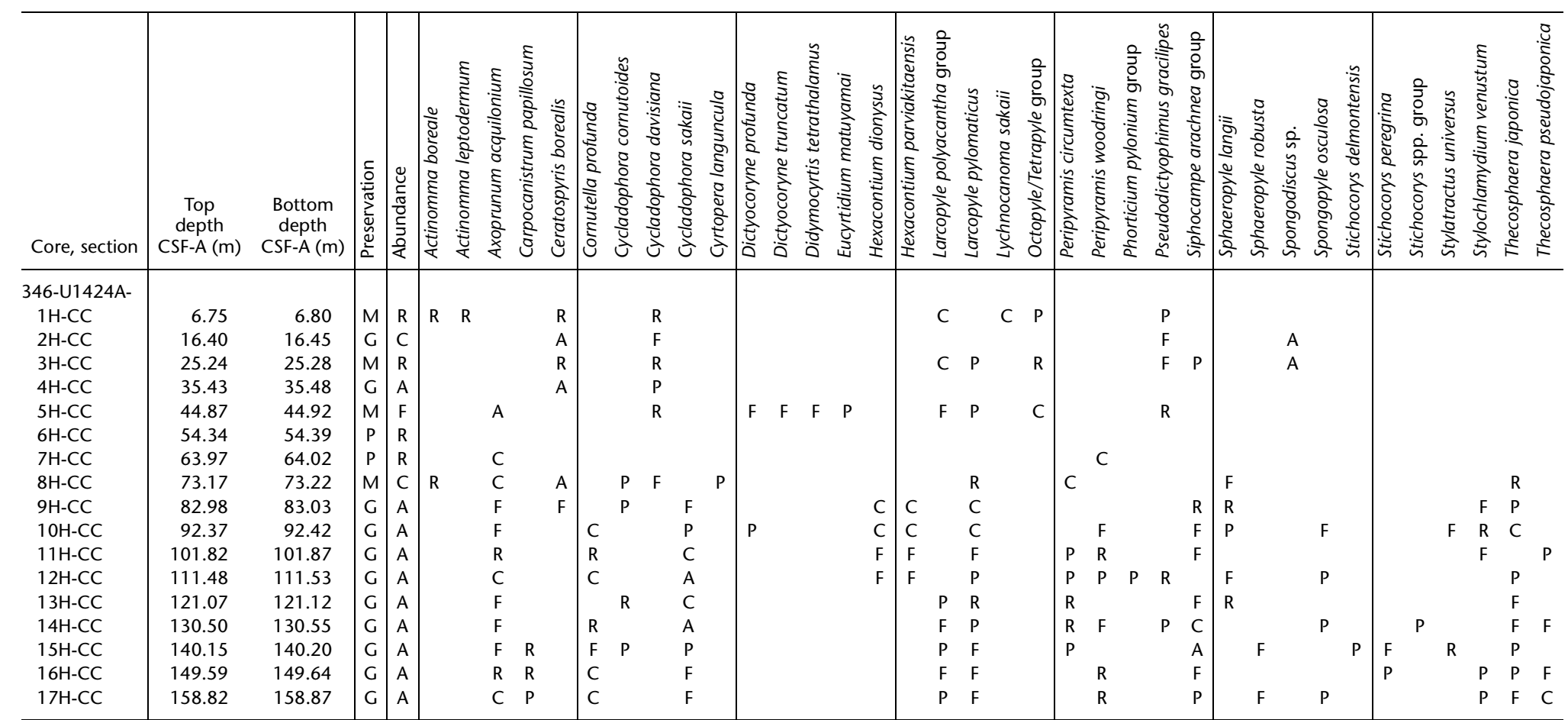

Preservation: $\mathrm{G}=$ good, $\mathrm{M}=$ moderate, $\mathrm{P}=$ poor. Abundance: $\mathrm{D}=$ dominant, $\mathrm{A}=$ abundant $\mathrm{C}=$ common, $\mathrm{F}=$ few, $\mathrm{R}=$ rare, $\mathrm{P}=$ present, $\mathrm{B}=$ barren. 


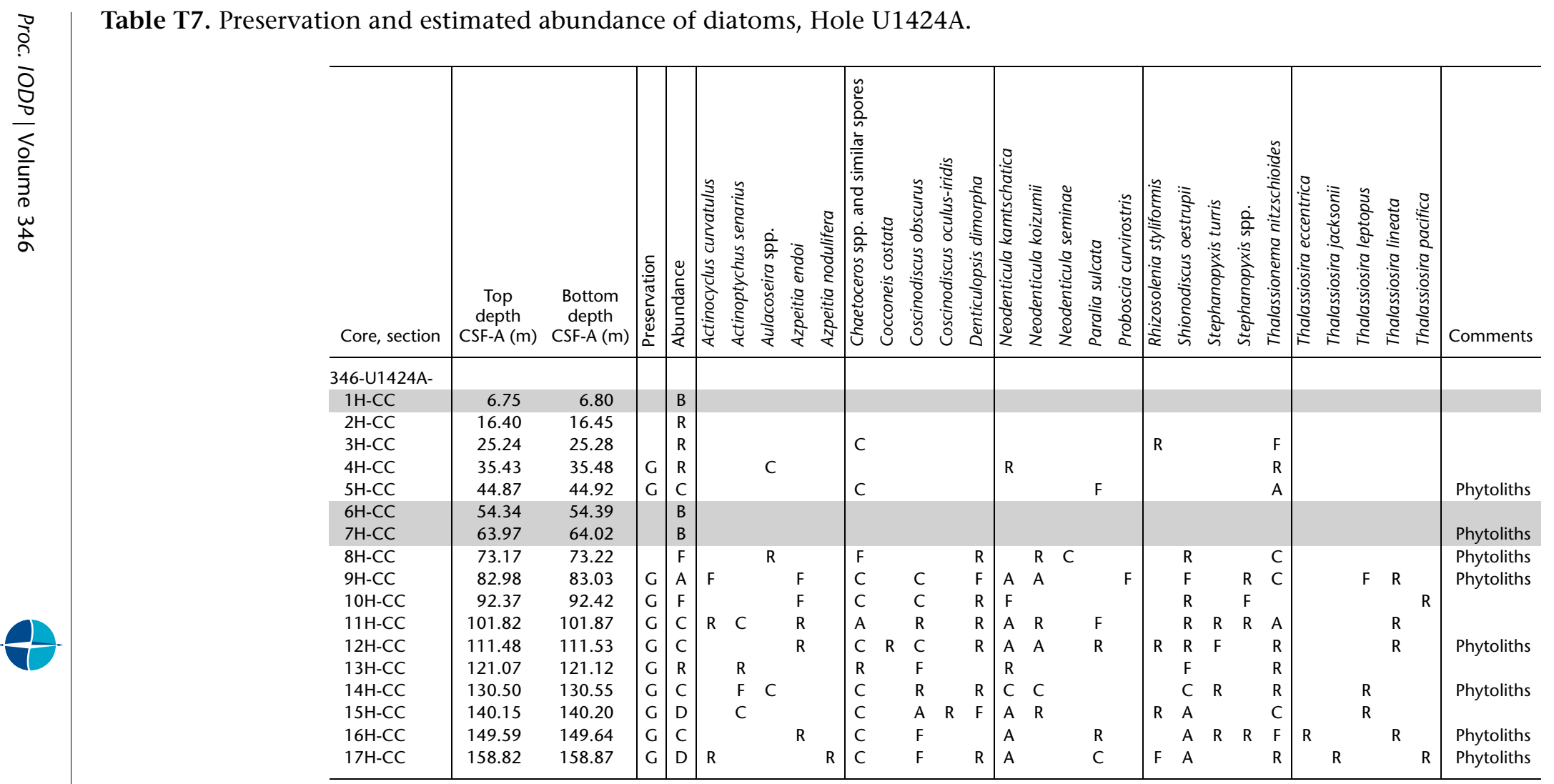

Preservation: $G=$ good. Abundance: $D=$ dominant, $A=$ abundant $C=$ common, $F=$ few, $R=$ rare, $B=$ barren. Shaded intervals $=$ barren. 
Table T8. Preservation and estimated abundance of planktonic foraminifers, Holes U1424A and U1424B.

\begin{tabular}{|c|c|c|c|c|c|c|c|c|c|c|c|c|c|}
\hline $\begin{array}{l}\text { Core, section, } \\
\text { interval }(\mathrm{cm})\end{array}$ & $\begin{array}{c}\text { Top } \\
\text { depth } \\
\text { CSF-A (m) }\end{array}$ & $\begin{array}{l}\text { Bottom } \\
\text { depth } \\
\text { CSF-A (m) }\end{array}$ & 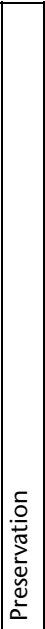 & 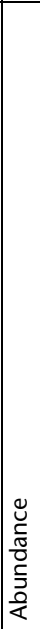 & 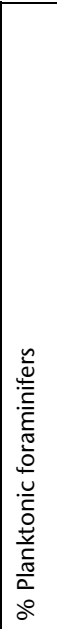 & 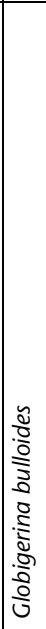 & 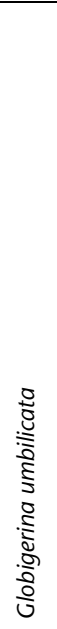 & 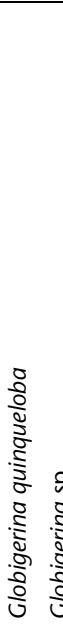 & 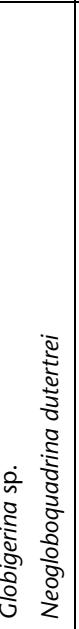 & 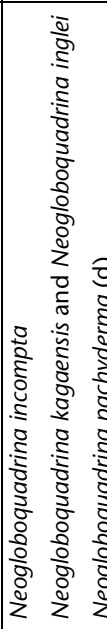 & 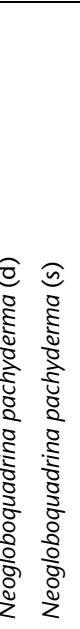 & 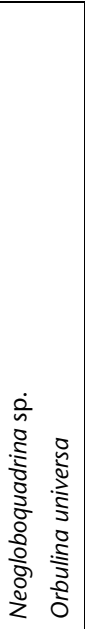 & 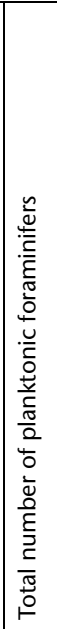 \\
\hline \multicolumn{13}{|l|}{ 346-U1424A- } & 99 \\
\hline $1 \mathrm{H}-\mathrm{CC}$ & 6.75 & 6.80 & $P$ & $\mathrm{R}$ & 100 & 7 & 1 & & & & 13 & & 21 \\
\hline $2 \mathrm{H}-7,53$ & 16.05 & 16.05 & $M$ & D & 100 & 38 & 2 & 13 & & & 46 & & 99 \\
\hline $2 \mathrm{H}-\mathrm{CC}$ & 16.40 & 16.50 & $G$ & A & 100 & 81 & 2 & & & & 113 & & 97 \\
\hline $3 \mathrm{H}-4,96-97$ & 21.76 & 21.80 & $P$ & D & 100 & 14 & & & & 1 & 383 & & 101 \\
\hline $3 \mathrm{H}-\mathrm{CC}$ & 25.24 & 21.28 & $G$ & D & 100 & 31 & & & 1 & & 53 & & 85 \\
\hline $4 \mathrm{H}-2,58-59$ & 27.88 & 27.89 & $P$ & D & 100 & & 1 & & & & 26 & & 79 \\
\hline $4 \mathrm{H}-2,135-136$ & 28.65 & 28.66 & $\mathrm{P}$ & D & 100 & 50 & 3 & 2 & & 122 & 227 & & 99 \\
\hline $4 \mathrm{H}-3,12-13$ & 28.92 & 28.93 & $M$ & D & 100 & 1 & & 18 & & 143 & 359 & & 98 \\
\hline $4 \mathrm{H}-5,123-124$ & 33.03 & 33.04 & & D & 100 & & & 1 & & 43 & 393 & & 101 \\
\hline $4 \mathrm{H}-\mathrm{CC}$ & 35.43 & 35.50 & $G$ & D & 100 & 7 & & & & & 272 & & 81 \\
\hline $5 \mathrm{H}-4,76-77$ & 40.56 & 40.57 & & B & & & & & & & & & 0 \\
\hline $5 \mathrm{H}-\mathrm{CC}$ & 44.87 & 44.90 & & B & & & & & & & & & 0 \\
\hline $6 \mathrm{H}-4,128-129$ & 50.58 & 50.59 & & B & & & & & & & & & 0 \\
\hline $6 \mathrm{H}-\mathrm{CC}$ & 54.34 & 54.40 & $\mathrm{P}$ & $\mathrm{R}$ & 100 & & & & 1 & & 1 & & 2 \\
\hline 7H-CC & 63.97 & 64.00 & & B & & & & & & & & & 0 \\
\hline $8 \mathrm{H}-\mathrm{CC}$ & 73.17 & 73.20 & & B & & & & & & & & & 0 \\
\hline $9 \mathrm{H}-\mathrm{CC}$ & 82.98 & 83.00 & $\mathrm{P}$ & $\mathrm{R}$ & 25 & 1 & & & & 1 & & & 2 \\
\hline $10 \mathrm{H}-\mathrm{CC}$ & 92.37 & 92.40 & & B & & & & & & & & & 0 \\
\hline $11 \mathrm{H}-4,36$ & 96.54 & 96.54 & & B & & & & & & & & & 0 \\
\hline $11 \mathrm{H}-7,100$ & 101.68 & 101.68 & & B & & & & & & & & & 0 \\
\hline $11 \mathrm{H}-\mathrm{CC}$ & 101.82 & 101.90 & & B & & & & & & & & & 0 \\
\hline $12 \mathrm{H}-\mathrm{CC}$ & 111.48 & 111.50 & & B & & & & & & & & & 0 \\
\hline $13 \mathrm{H}-\mathrm{CC}$ & 121.07 & 121.10 & & B & & & & & & & & & 0 \\
\hline $14 \mathrm{H}-\mathrm{CC}$ & 130.50 & 130.60 & & B & & & & & & & & & 0 \\
\hline $15 \mathrm{H}-\mathrm{CC}$ & 140.15 & 140.20 & & B & & & & & & & & & 0 \\
\hline $16 \mathrm{H}-\mathrm{CC}$ & 149.59 & 149.60 & & B & & & & & & & & & 0 \\
\hline $17 \mathrm{H}-\mathrm{CC}$ & 158.82 & 158.90 & $M$ & $\mathrm{~F}$ & 100 & 18 & & & & & $\begin{array}{ll}1 & 1\end{array}$ & 1 & 21 \\
\hline \multicolumn{14}{|l|}{ 346-U1424B- } \\
\hline $1 \mathrm{H}-\mathrm{CC}$ & 2.62 & 2.70 & & & 100 & 16 & 1 & & & & 16 & & 33 \\
\hline $2 \mathrm{H}-\mathrm{CC}$ & 11.92 & 12.00 & & & 100 & 2 & & & & & 3 & 1 & 5 \\
\hline $3 \mathrm{H}-\mathrm{CC}$ & 20.13 & 20.20 & & & 100 & 44 & 1 & 1 & 1 & & 54 & & 101 \\
\hline $4 \mathrm{H}-\mathrm{CC}$ & 30.88 & 30.90 & & & 99 & 14 & & & 2 & 1 & 162 & & 80 \\
\hline $16 \mathrm{H}-\mathrm{CC}$ & 145.53 & 145.60 & & B & & & & & & & & & 0 \\
\hline $17 \mathrm{H}-\mathrm{CC}$ & 155.02 & 155.10 & & B & & & & & & & & & 0 \\
\hline \multicolumn{14}{|l|}{ 346-U1424C- } \\
\hline $4 \mathrm{H}-\mathrm{CC}$ & 35.27 & 35.28 & & B & & & & & & & & & 0 \\
\hline $5 \mathrm{H}-\mathrm{CC}$ & 44.69 & 44.73 & & B & & & & & & & & & 0 \\
\hline $6 \mathrm{H}-\mathrm{CC}$ & 54.44 & 54.50 & & B & & & & & & & & & 0 \\
\hline 7H-CC & 63.97 & 64.02 & $M$ & D & 50 & 3 & & & & & 26 & & 29 \\
\hline
\end{tabular}

Numbers of specimens in core catcher samples refer to $\sim 30 \mathrm{~cm}^{3}$, whereas numbers in toothpick core samples refer to $1 \mathrm{~cm}^{3}$. Preservation: $\mathrm{G}=$ good, $M=$ moderate, $P=$ poor. Abundance: $D=$ dominant, $A=$ abundant, $F=f e w, R=$ rare, $B=$ barren. Shaded intervals $=$ barren. 
Table T9. Benthic foraminifers, Holes U1424A and U1424B.

\begin{tabular}{|c|c|c|c|c|c|c|c|c|c|c|c|c|c|c|c|c|c|}
\hline $\begin{array}{l}\text { Core, section, } \\
\text { interval }(\mathrm{cm})\end{array}$ & $\begin{array}{c}\text { Top } \\
\text { depth } \\
\text { CSF-A (m) }\end{array}$ & $\begin{array}{c}\text { Bottom } \\
\text { depth } \\
\text { CSF-A (m) }\end{array}$ & 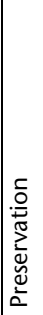 & 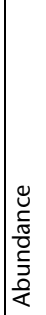 & 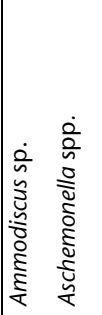 & 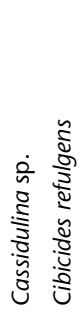 & 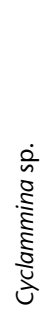 & 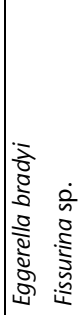 & 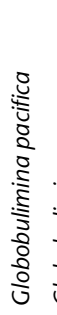 & 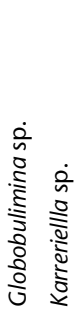 & 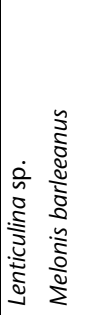 & 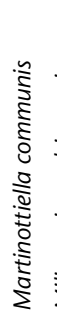 & 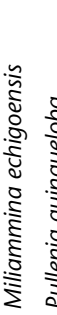 & 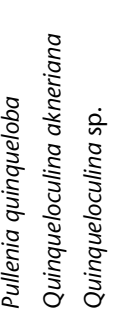 & 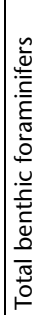 & 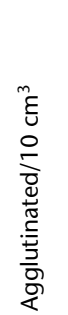 & 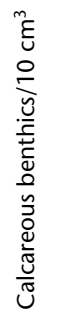 \\
\hline \multicolumn{18}{|l|}{ 346-U1424A- } \\
\hline $1 \mathrm{H}-4,42-43$ & 4.92 & 4.93 & & B & & & & & & & & & & & & & \\
\hline $1 \mathrm{H}-\mathrm{CC}$ & 6.75 & 6.80 & & B & & & & & & & & & & & & & \\
\hline $2 \mathrm{H}-7,52$ & 16.05 & 16.05 & & B & & & & & & & & & & & & & \\
\hline $2 \mathrm{H}-\mathrm{CC}$ & 16.40 & 16.45 & & B & & & & & & & & & & & & & \\
\hline $3 \mathrm{H}-4,96-97$ & 21.76 & 21.77 & & B & & & & & & & & & & & & & \\
\hline $3 \mathrm{H}-\mathrm{CC}$ & 25.24 & 25.28 & & B & & & & & & & & & & & & & \\
\hline $4 \mathrm{H}-2,135-136$ & 28.65 & 28.66 & & B & & & & & & & & & & & & & \\
\hline $4 \mathrm{H}-2,58-59$ & 27.88 & 27.89 & & B & & & & & & & & & & & & & \\
\hline $4 \mathrm{H}-5,123-124$ & 33.03 & 33.04 & & B & & & & & & & & & & & & & \\
\hline $4 \mathrm{H}-\mathrm{CC}$ & 35.43 & 35.48 & & B & & & & & & & & & & & & & \\
\hline $5 \mathrm{H}-4,76-77$ & 40.56 & 40.57 & & B & & & & & & & & & & & & & \\
\hline $5 \mathrm{H}-\mathrm{CC}$ & 44.87 & 44.92 & & B & & & & & & & & & & & & & \\
\hline $6 \mathrm{H}-4,128-129$ & 50.58 & 50.59 & & B & & & & & & & & & & & & & \\
\hline $6 \mathrm{H}-\mathrm{CC}$ & 54.34 & 54.39 & & B & & & & & & & & & & & & & \\
\hline 7H-CC & 63.97 & 64.02 & & B & & & & & & & & & & & & & \\
\hline $8 \mathrm{H}-\mathrm{CC}$ & 73.17 & 73.22 & & B & & & & & & & & & & & & & \\
\hline $9 \mathrm{H}-\mathrm{CC}$ & 82.98 & 83.03 & $M$ & $\mathrm{R}$ & & & & & & & & & 6 & & 6 & 2 & \\
\hline $10 \mathrm{H}-\mathrm{CC}$ & 92.37 & 92.42 & $M$ & $\mathrm{R}$ & & & & & & & & & 1 & & 1 & 0.3 & \\
\hline $11 \mathrm{H}-4,36$ & 96.54 & 96.54 & & B & & & & & & & & & & & & & \\
\hline $11 \mathrm{H}-7,100$ & 101.68 & 101.68 & & B & & & & & & & & & & & & & \\
\hline $11 \mathrm{H}-\mathrm{CC}$ & 101.82 & 101.87 & $P$ & $\mathrm{R}$ & & & & & & & & & 1 & & 1 & 0.3 & \\
\hline $12 \mathrm{H}-\mathrm{CC}$ & 111.48 & 111.53 & & B & & & & & & & & & & & & & \\
\hline $13 \mathrm{H}-\mathrm{CC}$ & 121.07 & 121.12 & $M$ & $\mathrm{R}$ & & & & & & & & 4 & & & 4 & 1.3 & \\
\hline $14 \mathrm{H}-\mathrm{CC}$ & 130.50 & 130.55 & & B & & & & & & & & & & & & & \\
\hline $15 \mathrm{H}-\mathrm{CC}$ & 140.15 & 140.20 & G & $\mathrm{R}$ & & & & & 1 & & & & 1 & & 2 & 0.7 & \\
\hline $16 \mathrm{H}-\mathrm{CC}$ & 149.59 & 149.64 & $M$ & $\mathrm{R}$ & $\begin{array}{llll} & 1 & & \\
\end{array}$ & & & 1 & & & & 1 & & & 3 & 0.7 & 0.3 \\
\hline $17 \mathrm{H}-\mathrm{CC}$ & 158.82 & 158.87 & $M$ & $R$ & & 1 & & & 1 & 1 & & 16 & 1 & 2 & 23 & 5.7 & 2 \\
\hline \multicolumn{18}{|l|}{ 346-U1424B- } \\
\hline $1 \mathrm{H}-\mathrm{CC}$ & 2.62 & 2.67 & & B & & & & & & & & & & & & & \\
\hline $2 \mathrm{H}-\mathrm{CC}$ & 11.92 & 11.97 & & B & & & & & & & & & & & & & \\
\hline $3 \mathrm{H}-\mathrm{CC}$ & 20.13 & 20.19 & & B & & & & & & & & & & & & & \\
\hline $4 \mathrm{H}-\mathrm{CC}$ & 30.88 & 30.93 & & $\mathrm{R}$ & & & & & & 1 & & & & & 1 & & 0.33 \\
\hline $4 \mathrm{H}-\mathrm{CC}$ & 30.88 & 30.90 & & B & & & & & & & & & & & & & \\
\hline $16 \mathrm{H}-\mathrm{CC}$ & 145.53 & 145.58 & $M$ & $\mathrm{R}$ & & & & & & & & 13 & & & 13 & 4.3 & 0 \\
\hline $17 \mathrm{H}-\mathrm{CC}$ & 155.02 & 155.08 & $M$ & $\mathrm{~F}$ & & 1 & 1 & & 1 & 16 & 1 & 36 & 4 & 1 & 52 & 15.7 & 2 \\
\hline \multicolumn{18}{|l|}{ 346-U1424C- } \\
\hline $4 \mathrm{H}-\mathrm{CC}$ & 35.27 & 35.28 & & B & & & & & & & & & & & & & \\
\hline $5 \mathrm{H}-\mathrm{CC}$ & 44.69 & 44.73 & $M$ & D & 100 & & & & & & & & & & 0 & 33.3 & 0 \\
\hline $6 \mathrm{H}-\mathrm{CC}$ & 54.44 & 54.49 & & B & & & & & & & & & & & 0 & 0 & 0 \\
\hline $7 \mathrm{H}-\mathrm{CC}$ & 63.97 & 64.02 & $P$ & D & & & & 1 & & & 1 & & & 21 & 23 & 0.7 & 7 \\
\hline
\end{tabular}

Numbers of specimens in core catcher samples refer to $\sim 30 \mathrm{~cm}^{3}$, whereas numbers in toothpick core samples refer to $1 \mathrm{~cm}^{3}$. Numbers of foraminifers $(>150 \mu \mathrm{m})$ per $10 \mathrm{~cm}^{3}$ are underestimated in samples with $>100$ specimens, as these samples were not completely picked. Preservation: $\mathrm{G}=$ good, $\mathrm{M}=$ moderate, $\mathrm{P}=$ poor. Abundance: $\mathrm{D}=$ dominant, $\mathrm{F}=$ few, $\mathrm{R}=$ rare, $\mathrm{B}=$ barren. Shaded intervals $=$ barren. 
Table T10. Calcium carbonate, total carbon (TC), total organic carbon (TOC), and total nitrogen (TN) contents on interstitial water squeeze cake sediment samples, Site U1424.

\begin{tabular}{lrrrrr}
\hline \multicolumn{1}{c}{ Hole } & $\begin{array}{c}\text { Top depth } \\
\text { CSF-A (m) }\end{array}$ & $\begin{array}{c}\text { Calcium } \\
\text { carbonate } \\
\text { (wt\%) }\end{array}$ & $\begin{array}{c}\text { TC } \\
\text { (wt\%) }\end{array}$ & $\begin{array}{c}\text { TOC } \\
\text { (wt\%) }\end{array}$ & $\begin{array}{c}\text { TN } \\
\text { (wt\%) }\end{array}$ \\
\hline $346-\mathrm{U} 1424 \mathrm{~A}-$ & & & & & \\
1H-1, 20-22 & 0.20 & 0.30 & 0.73 & 0.70 & 0.23 \\
$1 \mathrm{H}-1,26-28$ & 0.26 & 0.38 & 0.52 & 0.47 & 0.19 \\
$1 \mathrm{H}-1,80-82$ & 0.80 & 5.71 & 1.23 & 0.55 & 0.21 \\
$1 \mathrm{H}-1,113-115$ & 1.13 & 2.90 & 1.35 & 1.01 & 0.21 \\
$1 \mathrm{H}-1,145-150$ & 1.45 & 1.39 & 1.95 & 1.78 & 0.29 \\
$1 \mathrm{H}-3,25-27$ & 3.25 & 0.27 & 2.67 & 2.63 & 0.37 \\
$1 \mathrm{H}-3,41-43$ & 3.41 & 0.36 & 3.90 & 3.86 & 0.47 \\
$1 \mathrm{H}-3,74-76$ & 3.74 & 0.35 & 1.24 & 1.20 & 0.27 \\
$1 \mathrm{H}-3,81.5-83.5$ & 3.82 & 0.29 & 2.28 & 2.25 & 0.35 \\
$1 \mathrm{H}-3,87-89$ & 3.87 & 0.28 & 0.54 & 0.51 & 0.17 \\
$1 \mathrm{H}-4,44-46$ & 4.94 & 32.14 & 7.01 & 3.16 & 0.36 \\
$1 \mathrm{H}-4,121-123$ & 5.71 & 0.31 & 0.12 & 0.08 & 0.16 \\
$1 \mathrm{H}-5,10-12$ & 6.10 & 0.30 & 1.46 & 1.42 & 0.24 \\
$2 \mathrm{H}-1,145-150$ & 8.25 & 1.32 & 1.66 & 1.50 & 0.28 \\
$3 \mathrm{H}-1,145-150$ & 17.75 & 0.34 & 0.31 & 0.27 & 0.16 \\
$4 \mathrm{H}-1,145-150$ & 27.25 & 1.38 & 0.81 & 0.65 & 0.17 \\
$5 \mathrm{H}-1,145-150$ & 36.75 & 0.30 & 1.73 & 1.69 & 0.22 \\
$6 \mathrm{H}-1,145-150$ & 46.25 & 0.23 & 0.25 & 0.23 & 0.19 \\
7H-1, 145-150 & 55.75 & 0.25 & 0.12 & 0.09 & 0.20 \\
$8 \mathrm{H}-1,145-150$ & 65.25 & 2.13 & 1.40 & 1.15 & 0.24 \\
$9 \mathrm{H}-1,145-150$ & 74.75 & 0.29 & 0.52 & 0.49 & 0.45 \\
$10 \mathrm{H}-1,145-150$ & 84.25 & 0.41 & 0.33 & 0.28 & 0.18 \\
$11 \mathrm{H}-1,145-150$ & 93.75 & 0.37 & 0.22 & 0.18 & 0.18 \\
$12 \mathrm{H}-1,145-150$ & 103.25 & 0.35 & 0.23 & 0.19 & 0.17 \\
$13 \mathrm{H}-1,145-150$ & 112.75 & 0.37 & 0.43 & 0.39 & 0.17 \\
$14 \mathrm{H}-1,145-150$ & 122.25 & 0.42 & 0.25 & 0.20 & 0.13 \\
$15 \mathrm{H}-1,145-150$ & 131.75 & 0.70 & 0.53 & 0.44 & 0.18 \\
$16 \mathrm{H}-1,145-150$ & 141.25 & 44.01 & 5.86 & 0.58 & 0.13 \\
$17 \mathrm{H}-1,145-150$ & 150.75 & 0.36 & 0.32 & 0.28 & 0.17 \\
\hline & & & & & \\
\hline
\end{tabular}

Table T11. Interstitial water geochemistry, Site U1424. This table is available in an oversized format.

Table T12. Headspace (HS) gas concentrations, Site U1424.

\begin{tabular}{|c|c|c|c|c|c|}
\hline $\begin{array}{l}\text { Core, section, } \\
\text { interval }(\mathrm{cm})\end{array}$ & $\begin{array}{l}\text { Top depth } \\
\text { CSF-A (m) }\end{array}$ & $\begin{array}{l}\text { Sample } \\
\text { type }\end{array}$ & $\begin{array}{l}\text { Sediment } \\
\text { volume } \\
\left(\mathrm{cm}^{3}\right)\end{array}$ & $\begin{array}{c}\mathrm{CH}_{4} \\
\text { (ppmv) } \\
\text { measured }\end{array}$ & $\begin{array}{c}\mathrm{CH}_{4} \\
\text { (ppmv) } \\
\text { normalized }\end{array}$ \\
\hline \multicolumn{6}{|l|}{ 346-U1424A- } \\
\hline $1 \mathrm{H}-2,0-5$ & 1.5 & HS & 3.60 & 0.00 & 0.00 \\
\hline $3 \mathrm{H}-2,0-5$ & 17.8 & $\mathrm{HS}$ & 4.00 & 2.76 & 3.45 \\
\hline $4 \mathrm{H}-2,0-5$ & 27.3 & HS & 3.60 & 2.63 & 3.65 \\
\hline $5 \mathrm{H}-2,0-5$ & 36.8 & HS & 3.20 & 2.91 & 4.55 \\
\hline $6 \mathrm{H}-2,0-5$ & 46.3 & $\mathrm{HS}$ & 3.20 & 3.26 & 5.09 \\
\hline $7 \mathrm{H}-2,0-5$ & 55.8 & $\mathrm{HS}$ & 4.00 & 3.25 & 4.06 \\
\hline $8 \mathrm{H}-2,0-5$ & 65.3 & HS & 3.40 & 2.13 & 3.13 \\
\hline $9 \mathrm{H}-2,0-5$ & 74.8 & HS & 3.20 & 1.98 & 3.09 \\
\hline $10 \mathrm{H}-2,0-5$ & 84.3 & HS & 3.20 & 2.02 & 3.16 \\
\hline $11 \mathrm{H}-2,0-5$ & 93.8 & HS & 3.20 & 1.84 & 2.88 \\
\hline $12 \mathrm{H}-2,0-5$ & 103.3 & HS & 4.00 & 1.96 & 2.45 \\
\hline $13 \mathrm{H}-2,0-5$ & 112.8 & $\mathrm{HS}$ & 3.80 & 1.85 & 2.43 \\
\hline $14 \mathrm{H}-2,0-5$ & 122.3 & $\mathrm{HS}$ & 4.80 & 1.90 & 1.98 \\
\hline $15 \mathrm{H}-2,0-5$ & 131.8 & HS & 4.00 & 0.00 & 0.00 \\
\hline $16 \mathrm{H}-2,0-5$ & 141.3 & HS & 2.00 & 0.00 & 0.00 \\
\hline $17 \mathrm{H}-2,0-5$ & 150.8 & HS & 4.00 & 0.00 & 0.00 \\
\hline
\end{tabular}


Table T13. FlexIT tool core orientation data, Hole U1424A.

\begin{tabular}{crc}
\hline Core & $\begin{array}{c}\text { Orientation } \\
\text { angle } \\
\left({ }^{\circ}\right)\end{array}$ & $\begin{array}{c}\text { Orientation } \\
\text { standard } \\
\left({ }^{\circ}\right)\end{array}$ \\
\hline $346-U 1424 \mathrm{~A}-$ & & \\
$2 \mathrm{H}$ & 197.65 & 2.12 \\
$3 \mathrm{H}$ & 258.08 & 1.42 \\
$4 \mathrm{H}$ & 244.95 & 1.05 \\
$5 \mathrm{H}$ & 25.05 & 0.89 \\
$6 \mathrm{H}$ & 35.01 & 2.08 \\
$7 \mathrm{H}$ & 311.69 & 1.48 \\
$8 \mathrm{H}$ & 302.09 & 2.27 \\
$9 \mathrm{H}$ & 231.65 & 1.74 \\
$10 \mathrm{H}$ & 221.34 & 2.41 \\
$11 \mathrm{H}$ & 99.32 & 2.35 \\
$12 \mathrm{H}$ & 83.47 & 2.40 \\
$13 \mathrm{H}$ & 97.18 & 0.71 \\
$14 \mathrm{H}$ & 351.05 & 0.69 \\
$15 \mathrm{H}$ & 240.70 & 0.66 \\
$16 \mathrm{H}$ & 53.19 & 0.85 \\
$17 \mathrm{H}$ & 30.27 & 1.21 \\
\hline
\end{tabular}

Table T14. Core disturbance intervals, Site U1424. (Continued on next three pages.)

\begin{tabular}{|c|c|c|}
\hline $\begin{array}{l}\text { Core, section, } \\
\text { interval }(\mathrm{cm})\end{array}$ & Comments on disturbance & $\begin{array}{l}\text { Drilling disturbance } \\
\text { intensity }\end{array}$ \\
\hline \multicolumn{3}{|l|}{ 346-U1424A- } \\
\hline $1 \mathrm{H}-1,0-43$ & Soupy & Slight to moderate \\
\hline $1 \mathrm{H}-1,95-100$ & Mousselike & Slight to moderate \\
\hline $1 \mathrm{H}-1,126-139$ & Disturbance & \\
\hline $1 \mathrm{H}-2,0-103$ & Tilted & \\
\hline $1 \mathrm{H}-3,84-116$ & Disturbance and tilted & \\
\hline $1 \mathrm{H}-\mathrm{CC}, 0-8$ & & Slight \\
\hline $2 \mathrm{H}-2,92-98$ & Micromicrofault and tilted & \\
\hline $2 \mathrm{H}-4,0-3$ & & Moderate \\
\hline $2 \mathrm{H}-\mathrm{CC}, 0-10$ & Mousselike & Slight \\
\hline $3 \mathrm{H}-2,79-89$ & Deformed & \\
\hline $3 \mathrm{H}-2,143-146$ & Microfault & \\
\hline $3 \mathrm{H}-3,77-81$ & Deformed & \\
\hline $3 \mathrm{H}-3,129-133$ & Microfault & \\
\hline $3 \mathrm{H}-5,135-138$ & Deformed & \\
\hline $3 \mathrm{H}-6,114-138$ & & Moderate \\
\hline $4 \mathrm{H}-1,0-14$ & & Moderate \\
\hline $4 \mathrm{H}-1,47-150$ & Micromicrofault and tilted & \\
\hline $4 \mathrm{H}-3,41-45$ & Microfault & \\
\hline $4 \mathrm{H}-3,61-101$ & Microfault & \\
\hline $4 \mathrm{H}-3,117-123$ & Microfault & \\
\hline $5 \mathrm{H}-1,0-24$ & Disturbance and tilted & Moderate \\
\hline $5 \mathrm{H}-3,37-41$ & Microfault & \\
\hline $5 \mathrm{H}-3,110-132$ & Micromicrofault and tilted & \\
\hline $5 \mathrm{H}-4,90-97$ & Microfault & \\
\hline $5 \mathrm{H}-4,131-142$ & Microfault & \\
\hline $5 \mathrm{H}-5,140-150$ & Microfault & \\
\hline $5 \mathrm{H}-6,35-44$ & Microfault & \\
\hline $6 \mathrm{H}-1,0-5$ & & Moderate \\
\hline $6 \mathrm{H}-2,131-139$ & Microfault & \\
\hline $6 \mathrm{H}-3,68-71$ & Microfault & \\
\hline $6 \mathrm{H}-6,31-36$ & Microfault & \\
\hline $7 \mathrm{H}-1,44-63$ & Deformed & \\
\hline 7H-1, 76-81 & Tilted & \\
\hline $7 \mathrm{H}-2,64-71$ & Deformed & \\
\hline 7H-2, 109-119 & Tilted and deformed & \\
\hline $7 \mathrm{H}-2,134-150$ & Tilted and deformed & \\
\hline $7 \mathrm{H}-3,92-96$ & Ash washed off? & \\
\hline 7H-5, 108-115 & Microfault & \\
\hline $8 \mathrm{H}-1,0-109$ & Destroyed & \\
\hline $8 \mathrm{H}-1,115-118$ & Deformed & \\
\hline $8 \mathrm{H}-5,69-77$ & Microfault & \\
\hline
\end{tabular}


Table T14 (continued). (Continued on next page.)

\begin{tabular}{|c|c|c|}
\hline $\begin{array}{l}\text { Core, section, } \\
\text { interval }(\mathrm{cm})\end{array}$ & Comments on disturbance & $\begin{array}{l}\text { Drilling disturbance } \\
\text { intensity }\end{array}$ \\
\hline $8 \mathrm{H}-6,35-40$ & Tilted & \\
\hline $8 \mathrm{H}-6,78-82$ & Tilted & \\
\hline $8 \mathrm{H}-7,0-11$ & Tilted & \\
\hline $9 \mathrm{H}-1,0-30$ & Disturbance and tilted & Moderate to high \\
\hline $9 \mathrm{H}-2,27-31$ & Microfault & \\
\hline $9 \mathrm{H}-2,35-40$ & Microfault & \\
\hline $9 \mathrm{H}-3,125-150$ & Microfault & \\
\hline $9 \mathrm{H}-6,17-28$ & Microfault & \\
\hline $10 \mathrm{H}-1,92-135$ & & Moderate to high \\
\hline $10 \mathrm{H}-2,42-49$ & Microfault & \\
\hline $10 \mathrm{H}-4,88-91$ & Microfault & \\
\hline $10 \mathrm{H}-4,124-134$ & Microfault & \\
\hline $10 \mathrm{H}-\mathrm{CC}, 0-8$ & & Slight \\
\hline $11 \mathrm{H}-1,0-5$ & & Slight \\
\hline $11 \mathrm{H}-1,42-49$ & Microfault & \\
\hline $11 \mathrm{H}-3,0-32$ & Microfault & \\
\hline $11 \mathrm{H}-4,0-36$ & & Moderate \\
\hline $11 \mathrm{H}-4,129-150$ & Microfault & \\
\hline $11 \mathrm{H}-5,15-27$ & Microfault & \\
\hline $11 \mathrm{H}-5,140-143$ & Microfault & \\
\hline $11 \mathrm{H}-6,22-32$ & Microfault & \\
\hline $11 \mathrm{H}-\mathrm{CC}, 0-7$ & & Slight \\
\hline $12 \mathrm{H}-1,29-34$ & Microfault & \\
\hline $12 \mathrm{H}-1,47-52$ & Microfault & \\
\hline $12 \mathrm{H}-2,0-3$ & & Slight \\
\hline $12 \mathrm{H}-2,34-89$ & Mixed & \\
\hline $12 \mathrm{H}-5,118-138$ & Microfault & \\
\hline $13 \mathrm{H}-3,21-25$ & Microfault & \\
\hline $13 \mathrm{H}-3,39-48$ & Microfault & \\
\hline $13 \mathrm{H}-3,65-69$ & Microfault & \\
\hline $13 \mathrm{H}-4,20-32$ & Microfault & \\
\hline $13 \mathrm{H}-5,19-27$ & Nodule and disturbance & \\
\hline $13 \mathrm{H}-5,89-97$ & Microfault & \\
\hline $13 \mathrm{H}-7,0-11$ & Ash and disturbance & \\
\hline $13 \mathrm{H}-\mathrm{CC}, 12-14$ & & Slight \\
\hline $14 \mathrm{H}-1,0-28$ & & Slight \\
\hline $14 \mathrm{H}-3,105-119$ & & Moderate \\
\hline $14 \mathrm{H}-4,0-145$ & Mass transfer deposit & \\
\hline $14 \mathrm{H}-5,0-145$ & Mass transfer deposit & \\
\hline $14 \mathrm{H}-6,0-150$ & Flow-in? & \\
\hline \multicolumn{3}{|l|}{$14 \mathrm{H}-7,0-60$} \\
\hline $15 \mathrm{H}-1,0-5$ & & Moderate \\
\hline $15 \mathrm{H}-3,76-89$ & Disturbed & \\
\hline $15 \mathrm{H}-4,112-150$ & & High \\
\hline $15 \mathrm{H}-5,0-102$ & & High \\
\hline $15 \mathrm{H}-5,113-120$ & Microfault & \\
\hline $15 \mathrm{H}-6,94-102$ & Deformed & \\
\hline $15 \mathrm{H}-\mathrm{CC}, 0-29$ & & Moderate \\
\hline $16 \mathrm{H}-1,105-117$ & Microfault & \\
\hline $16 \mathrm{H}-5,102-113$ & Microfault & \\
\hline $16 \mathrm{H}-\mathrm{CC}, 0-25$ & & Moderate \\
\hline $17 \mathrm{H}-1,0-74$ & Disturbance & \\
\hline \multicolumn{3}{|l|}{ 346-U1424B- } \\
\hline $1 \mathrm{H}-1,0-50$ & Soupy & \\
\hline $1 \mathrm{H}-1,128-150$ & Microfault & \\
\hline $1 \mathrm{H}-2,51-62$ & Microfault & \\
\hline $1 \mathrm{H}-2,90-104$ & Microfault & \\
\hline $2 \mathrm{H}-1,0-4$ & & Destroyed \\
\hline $2 \mathrm{H}-2,20-25$ & Microfault & \\
\hline $2 \mathrm{H}-2,67-100$ & Tilted & \\
\hline $2 \mathrm{H}-3,0-16$ & & Slight \\
\hline $2 \mathrm{H}-3,26-33$ & Tilted & \\
\hline $2 \mathrm{H}-3,115-125$ & Disturb & \\
\hline $2 \mathrm{H}-4,19-43$ & Tilted & \\
\hline $2 \mathrm{H}-4,110-116$ & Microfault & \\
\hline $3 \mathrm{H}-1,0-8$ & & Moderate to high \\
\hline $3 \mathrm{H}-1,18-26$ & Microfault & \\
\hline $3 \mathrm{H}-1,126-128$ & Microfault & \\
\hline $3 \mathrm{H}-2,15-95$ & Tilted & \\
\hline
\end{tabular}


Table T14 (continued). (Continued on next page.)

\begin{tabular}{|c|c|c|}
\hline $\begin{array}{l}\text { Core, section, } \\
\text { interval }(\mathrm{cm})\end{array}$ & Comments on disturbance & $\begin{array}{l}\text { Drilling disturbance } \\
\text { intensity }\end{array}$ \\
\hline $3 \mathrm{H}-3,51-59$ & Tilted & \\
\hline $3 \mathrm{H}-3,63-85$ & Tilted & \\
\hline $3 \mathrm{H}-5,6-13$ & Tilted & \\
\hline $3 \mathrm{H}-5,55-62$ & Deformed & \\
\hline $4 \mathrm{H}-1,15-21$ & Microfault & \\
\hline $4 \mathrm{H}-1,125-136$ & Void & Destroyed \\
\hline $4 \mathrm{H}-2,17-21$ & Microfault & \\
\hline $4 \mathrm{H}-3,52-56$ & Microfault & \\
\hline $4 \mathrm{H}-3,80-84$ & Deformed & \\
\hline $4 \mathrm{H}-4,96-119$ & Microfault & \\
\hline $5 \mathrm{H}-1,0-96$ & & Destroyed \\
\hline $5 \mathrm{H}-1,0-28$ & Microfault & \\
\hline $5 \mathrm{H}-2,100-109$ & Microfault & \\
\hline $5 \mathrm{H}-3,45-52$ & Microfault & \\
\hline $5 \mathrm{H}-3,140-150$ & Microfault & \\
\hline $5 \mathrm{H}-4,40-51$ & Void & Destroyed \\
\hline $5 \mathrm{H}-4,126-133$ & Microfault & \\
\hline $5 \mathrm{H}-6,20-21$ & Microfault? & \\
\hline $5 \mathrm{H}-6,113-116$ & Microfault & \\
\hline $5 \mathrm{H}-7,55-102$ & Void & Destroyed \\
\hline $6 \mathrm{H}-1,0-22$ & Microfault & \\
\hline $6 \mathrm{H}-1,34-51$ & Microfault & \\
\hline $6 \mathrm{H}-2,21-29$ & Microfault & \\
\hline $6 \mathrm{H}-2,69-80$ & Microfault & \\
\hline $6 \mathrm{H}-4,95-105$ & Microfault & \\
\hline $6 \mathrm{H}-4,113-117$ & Microfault & \\
\hline $6 \mathrm{H}-6,70-78$ & Microfault & \\
\hline $6 \mathrm{H}-7,29-61$ & & High \\
\hline $7 \mathrm{H}-1,68-77$ & Microfault & \\
\hline 7H-1, 85-104 & Microfault & \\
\hline $7 \mathrm{H}-1,100.5-103$ & Void & Destroyed \\
\hline $7 \mathrm{H}-2,54-61$ & Microfault & \\
\hline 7H-2, 86-91 & & Moderate \\
\hline 7H-2, 108-113 & & Moderate to high \\
\hline $7 \mathrm{H}-3,18-26$ & Disturbed with ash & \\
\hline $7 \mathrm{H}-5,8-22$ & Disturbed? & \\
\hline 7H-7, 0-69 & & High \\
\hline $8 \mathrm{H}-1,110-127$ & Microfault & \\
\hline $8 \mathrm{H}-2,0-53$ & Void & Destroyed \\
\hline $8 \mathrm{H}-3,26-32$ & Microfault & \\
\hline $8 \mathrm{H}-5,67-80$ & Microfault & \\
\hline $8 \mathrm{H}-6,74-90$ & Microfault & \\
\hline $8 \mathrm{H}-7,0-24$ & Microfault & \\
\hline $8 \mathrm{H}-\mathrm{CC}, 0-17$ & & Slight \\
\hline $9 \mathrm{H}-1,0-8$ & & Slight to moderate \\
\hline $9 \mathrm{H}-3,30-33$ & Fall-in & High \\
\hline $9 \mathrm{H}-4,21-24$ & Fault & \\
\hline $9 \mathrm{H}-4,99-106$ & Fault & \\
\hline $9 \mathrm{H}-4,114-121$ & Fault & \\
\hline $9 \mathrm{H}-4,137-150$ & Fault & \\
\hline $9 \mathrm{H}-5,31-37$ & Fault & \\
\hline $9 \mathrm{H}-5,90-96$ & Fault & \\
\hline $9 \mathrm{H}-5,103-108$ & Fault & \\
\hline $9 \mathrm{H}-6,0-15$ & Fault & \\
\hline $9 \mathrm{H}-6,64-69$ & Fault & \\
\hline $9 \mathrm{H}-6,98-106$ & Fault & \\
\hline $9 \mathrm{H}-6,127-140$ & Fault & \\
\hline $10 \mathrm{H}-3,0-19$ & Fault & \\
\hline $10 \mathrm{H}-4,0-150$ & Potential flow-in & Moderate to high \\
\hline $10 \mathrm{H}-\mathrm{CC}, 12-18$ & & Slight \\
\hline $11 \mathrm{H}-1,0-31$ & & Slight \\
\hline $11 \mathrm{H}-\mathrm{CC}, 0-18$ & & Slight \\
\hline $11 \mathrm{H}-\mathrm{CC}, 0-18$ & & Slight \\
\hline $12 \mathrm{H}-4,28-40$ & Disturbed? & \\
\hline $13 \mathrm{H}-1,0-23$ & & Moderate to high \\
\hline $13 \mathrm{H}-5,134-150$ & Microfault & \\
\hline $13 \mathrm{H}-6,97-110$ & Microfault & \\
\hline $13 \mathrm{H}-6,127-150$ & Microfault & \\
\hline $13 \mathrm{H}-\mathrm{CC}, 0-19$ & & Slight to moderate \\
\hline
\end{tabular}


Table T14 (continued).

\begin{tabular}{|c|c|c|}
\hline $\begin{array}{l}\text { Core, section, } \\
\text { interval }(\mathrm{cm})\end{array}$ & Comments on disturbance & $\begin{array}{l}\text { Drilling disturbance } \\
\text { intensity }\end{array}$ \\
\hline $14 \mathrm{H}-1,72-116$ & Soupy ash & \\
\hline $14 \mathrm{H}-1,140-150$ & Microfault & \\
\hline $14 \mathrm{H}-2,110-124$ & Microfault & \\
\hline $14 \mathrm{H}-3,64-103$ & Microfault & \\
\hline $14 \mathrm{H}-3,129-150$ & Microfault & \\
\hline $15 \mathrm{H}-3,0-93$ & Microfault & \\
\hline $15 \mathrm{H}-5,0-150$ & Flow-in & \\
\hline $15 \mathrm{H}-6,0-150$ & Microfault & Microfault \\
\hline $15 \mathrm{H}-7,0-53$ & Flow-in & \\
\hline $16 \mathrm{H}-1,131-134$ & Microfault & \\
\hline $16 \mathrm{H}-3,25-31$ & Microfault & \\
\hline $16 \mathrm{H}-3,127-133$ & Microfault & \\
\hline $17 \mathrm{H}-1,0-10$ & & Moderate \\
\hline $17 \mathrm{H}-3,94-96$ & Microfault & \\
\hline $17 \mathrm{H}-4,0-26$ & Microfault & \\
\hline $17 \mathrm{H}-6,28-31$ & Microfault & \\
\hline $17 \mathrm{H}-7,34-59$ & Mass transfer deposit & \\
\hline \multicolumn{3}{|l|}{ 346-U1424C- } \\
\hline $4 \mathrm{H}-1,0-39$ & & Moderate \\
\hline $4 \mathrm{H}-4,79-83$ & Tilted & \\
\hline $4 \mathrm{H}-5,57-69$ & Tilted & \\
\hline $4 \mathrm{H}-5,108-150$ & Slightly deformed & \\
\hline $4 \mathrm{H}-6,25-90$ & Tilted & \\
\hline $4 \mathrm{H}-7,0-10$ & Tilted & \\
\hline $5 \mathrm{H}-1,0-8$ & & Slight to moderate \\
\hline $5 \mathrm{H}-1,0-10$ & Tilted and deformed & \\
\hline $5 \mathrm{H}-1,25-34$ & Tilted and deformed & \\
\hline $5 \mathrm{H}-1,55-80$ & Tilted and deformed & \\
\hline $5 \mathrm{H}-2,15-22$ & Tilted, deformed, and ash & \\
\hline $5 \mathrm{H}-2,45-120$ & Tilted and ash & \\
\hline $5 \mathrm{H}-3,28-33$ & Disturbed & \\
\hline $5 \mathrm{H}-3,90-95$ & Tilted & \\
\hline $5 \mathrm{H}-4,30-38$ & Fault & \\
\hline $5 \mathrm{H}-4,80-88$ & Disturbed & \\
\hline $5 \mathrm{H}-5,100-150$ & Tilted & \\
\hline $5 \mathrm{H}-6,0-10$ & Microfault & \\
\hline $5 \mathrm{H}-6,85-110$ & Tilted & \\
\hline $5 \mathrm{H}-7,0-54$ & & Moderate to high \\
\hline $6 \mathrm{H}-2,13-32$ & Fault & \\
\hline $6 \mathrm{H}-2,105-107$ & Fault & \\
\hline $6 \mathrm{H}-6,48-64$ & Tilted and disturbed & \\
\hline $7 \mathrm{H}-1,0-30$ & Slightly disturbed & \\
\hline $7 \mathrm{H}-2,0-20$ & Fault & \\
\hline $7 \mathrm{H}-3,15-20$ & Soupy ash & \\
\hline $7 \mathrm{H}-3,23-65$ & Mass transfer deposit and microfault & \\
\hline $7 \mathrm{H}-4,35-115$ & Suck-in & \\
\hline $7 \mathrm{H}-5,130-150$ & Tilted & \\
\hline $7 \mathrm{H}-6,85-90$ & Fault & \\
\hline 7H-7, 10-30 & Fault & \\
\hline $7 \mathrm{H}-7,45-55$ & Tilted & \\
\hline
\end{tabular}


Table T15. NRM inclination, declination, and intensity data after $20 \mathrm{mT}$ peak field AF demagnetization, Site U1424.

\begin{tabular}{|c|c|c|c|c|c|}
\hline $\begin{array}{l}\text { Core, section, } \\
\text { interval }(\mathrm{cm})\end{array}$ & $\begin{array}{c}\text { Depth } \\
\text { CSF-A (m) }\end{array}$ & $\begin{array}{c}\text { Inclination } \\
\left({ }^{\circ}\right)\end{array}$ & $\begin{array}{l}\text { Declination } \\
\left({ }^{\circ}\right)\end{array}$ & $\begin{array}{l}\text { FlexIT-corrected } \\
\text { declination } \\
\left({ }^{\circ}\right)\end{array}$ & $\begin{array}{l}\text { Intensity } \\
(\mathrm{A} / \mathrm{m})\end{array}$ \\
\hline \multicolumn{6}{|l|}{ 346-U1424A- } \\
\hline $1 \mathrm{H}-1$ & 0 & & & & \\
\hline $1 \mathrm{H}-1,5$ & 0.05 & & & & \\
\hline $1 \mathrm{H}-1,10$ & 0.1 & & & & \\
\hline $1 \mathrm{H}-1,15$ & 0.15 & & & & \\
\hline $1 \mathrm{H}-1,20$ & 0.2 & & & & \\
\hline $1 \mathrm{H}-1,25$ & 0.25 & & & & \\
\hline $1 \mathrm{H}-1,30$ & 0.3 & & & & \\
\hline $1 \mathrm{H}-1,35$ & 0.35 & & & & \\
\hline $1 \mathrm{H}-1,40$ & 0.4 & & & & \\
\hline $1 \mathrm{H}-1,45$ & 0.45 & 71 & 174.7 & & 0.008732 \\
\hline $1 \mathrm{H}-1,50$ & 0.5 & 69.5 & 150.4 & & 0.007591 \\
\hline $1 \mathrm{H}-1,55$ & 0.55 & 78.5 & 167.8 & & 0.010352 \\
\hline $1 \mathrm{H}-1,60$ & 0.6 & 72.8 & 200.9 & & 0.016787 \\
\hline $1 \mathrm{H}-1,65$ & 0.65 & 67.2 & 193.4 & & 0.024067 \\
\hline $1 \mathrm{H}-1,70$ & 0.7 & 60.4 & 200.6 & & 0.025928 \\
\hline $1 \mathrm{H}-1,75$ & 0.75 & 62.4 & 193.2 & & 0.02223 \\
\hline $1 \mathrm{H}-1,80$ & 0.8 & 68.8 & 194.4 & & 0.021969 \\
\hline $1 \mathrm{H}-1,85$ & 0.85 & 65.5 & 192.4 & & 0.02714 \\
\hline $1 \mathrm{H}-1,90$ & 0.9 & 64.8 & 192.1 & & 0.029768 \\
\hline $1 \mathrm{H}-1,95$ & 0.95 & & & & \\
\hline $1 \mathrm{H}-1,100$ & 1 & & & & \\
\hline $1 \mathrm{H}-1,105$ & 1.05 & 58.9 & 143.5 & & 0.017741 \\
\hline $1 \mathrm{H}-1,110$ & 1.1 & 54.4 & 149.6 & & 0.019149 \\
\hline $1 \mathrm{H}-1,115$ & 1.15 & 60.6 & 158.4 & & 0.012374 \\
\hline $1 \mathrm{H}-1,120$ & 1.2 & 68.9 & 165.3 & & 0.006472 \\
\hline $1 \mathrm{H}-1,125$ & 1.25 & 82.3 & 153.9 & & 0.00264 \\
\hline $1 \mathrm{H}-1,130$ & 1.3 & & & & \\
\hline $1 \mathrm{H}-1,135$ & 1.35 & & & & \\
\hline $1 \mathrm{H}-1,140$ & 1.4 & & & & \\
\hline $1 \mathrm{H}-1,145$ & 1.45 & & & & \\
\hline $1 \mathrm{H}-1,150$ & 1.5 & & & & \\
\hline $1 \mathrm{H}-2$ & 1.5 & & & & \\
\hline $1 \mathrm{H}-2,5$ & 1.55 & & & & \\
\hline $1 \mathrm{H}-2,10$ & 1.6 & & & & \\
\hline $1 \mathrm{H}-2,15$ & 1.65 & & & & \\
\hline $1 \mathrm{H}-2,20$ & 1.7 & & & & \\
\hline $1 \mathrm{H}-2,25$ & 1.75 & & & & \\
\hline $1 \mathrm{H}-2,30$ & 1.8 & & & & \\
\hline $1 \mathrm{H}-2,35$ & 1.85 & & & & \\
\hline $1 \mathrm{H}-2,40$ & 1.9 & & & & \\
\hline $1 \mathrm{H}-2,45$ & 1.95 & & & & \\
\hline $1 \mathrm{H}-2,50$ & 2 & & & & \\
\hline $1 \mathrm{H}-2,55$ & 2.05 & & & & \\
\hline $1 \mathrm{H}-2,60$ & 2.1 & & & & \\
\hline $1 \mathrm{H}-2,65$ & 2.15 & & & & \\
\hline $1 \mathrm{H}-2,70$ & 2.2 & & & & \\
\hline $1 \mathrm{H}-2,75$ & 2.25 & & & & \\
\hline $1 \mathrm{H}-2,80$ & 2.3 & & & & \\
\hline $1 \mathrm{H}-2,85$ & 2.35 & & & & \\
\hline $1 \mathrm{H}-2,90$ & 2.4 & & & & \\
\hline $1 \mathrm{H}-2,95$ & 2.45 & & & & \\
\hline $1 \mathrm{H}-2,100$ & 2.5 & & & & \\
\hline $1 \mathrm{H}-2,105$ & 2.55 & 55.2 & 210.7 & & 0.029328 \\
\hline $1 \mathrm{H}-2,110$ & 2.6 & 65.7 & 193.4 & & 0.031403 \\
\hline $1 \mathrm{H}-2,115$ & 2.65 & 58.2 & 184.6 & & 0.035638 \\
\hline $1 \mathrm{H}-2,120$ & 2.7 & 53.2 & 190.9 & & 0.041672 \\
\hline $1 \mathrm{H}-2,125$ & 2.75 & 57.5 & 189.6 & & 0.03697 \\
\hline $1 \mathrm{H}-2,130$ & 2.8 & 55.7 & 179.3 & & 0.035641 \\
\hline $1 \mathrm{H}-2,135$ & 2.85 & 58.2 & 181 & & 0.035646 \\
\hline
\end{tabular}

Blank cells indicate depth levels where data were either not available (i.e., FlexIT-corrected declination data for nonoriented cores) or removed because of disturbance, voids, or measurement edge effects. Only a portion of this table appears here. The complete table is available in ASCII. 
Table T16. Polarity boundaries, Site U1424. (Continued on next page.)

\begin{tabular}{|c|c|c|c|c|c|c|c|c|c|c|c|}
\hline \multicolumn{2}{|c|}{ Core, section, interval $(\mathrm{cm})$} & \multirow[b]{2}{*}{ Polarity boundaries } & \multirow{2}{*}{$\begin{array}{l}\text { Age } \\
(\mathrm{Ma})\end{array}$} & \multicolumn{4}{|c|}{ Depth CSF-A (m) } & \multicolumn{4}{|c|}{ Depth CCSF (m) } \\
\hline Top & Bottom & & & Top & Bottom & Midpoint & \pm & Top & Bottom & Midpoint & \pm \\
\hline 346-U1424A- & 346-U1424A- & & & & & & & & & & \\
\hline $3 \mathrm{H}-6, \sim 10$ & $4 \mathrm{H}-1, \sim 0$ & (B) C1n (Brunhes/Matuyama) & 0.781 & 23.90 & 25.70 & 24.80 & 0.90 & 25.80 & 27.60 & 26.70 & 0.90 \\
\hline $4 \mathrm{H}-4, \sim 30$ & $4 \mathrm{H}-5, \sim 20$ & (T) C1r.1n (Jaramillo) & 0.988 & 30.60 & 32.00 & 31.30 & 0.70 & 33.90 & 35.30 & 34.60 & 0.70 \\
\hline $5 \mathrm{H}-1, \sim 90$ & $5 \mathrm{H}-2, \sim 20$ & (B) C1r.1n (Jaramillo) & 1.072 & 36.20 & 37.00 & 36.60 & 0.40 & 40.20 & 41.00 & 40.60 & 0.40 \\
\hline $5 \mathrm{H}-5, \sim 10$ & $5 \mathrm{H}-5, \sim 30$ & (T) C1r.2n (Cobb Mountain) & 1.173 & 41.40 & 41.60 & 41.50 & 0.10 & 45.40 & 45.60 & 45.50 & 0.10 \\
\hline $5 \mathrm{H}-5, \sim 100$ & $5 \mathrm{H}-5, \sim 120$ & (B) C1r.2n (Cobb Mountain) & 1.185 & 42.30 & 42.50 & 42.40 & 0.10 & 46.30 & 46.50 & 46.40 & 0.10 \\
\hline $6 \mathrm{H}-7, \sim 50$ & $7 \mathrm{H}-1, \sim 30$ & (T) C2n (Olduvai) & 1.778 & 54.00 & 54.60 & 54.30 & 0.30 & 59.13 & 59.73 & 59.43 & 0.30 \\
\hline $7 \mathrm{H}-3, \sim 140$ & $7 \mathrm{H}-4, \sim 10$ & (B) C2n (Olduvai) & 1.945 & 58.70 & 58.90 & 58.80 & 0.10 & 63.83 & 64.03 & 63.93 & 0.10 \\
\hline $7 \mathrm{H}-6, \sim 50$ & $7 \mathrm{H}-6, \sim 110$ & (T) C2r.1n (Reunion) & 2.128 & 62.30 & 62.90 & 62.60 & 0.30 & 67.43 & 68.03 & 67.73 & 0.30 \\
\hline $7 \mathrm{H}-7, \sim 20$ & $7 \mathrm{H}-7, \sim 40$ & (B) C2r.1n (Reunion) & 2.148 & 63.50 & 63.70 & 63.60 & 0.10 & 68.63 & 68.83 & 68.73 & 0.10 \\
\hline $9 \mathrm{H}-2, \sim 50$ & $9 \mathrm{H}-2, \sim 130$ & (T) C2An.1n (Matuyama/Gauss) & 2.581 & 75.30 & 76.10 & 75.70 & 0.40 & 80.64 & 81.44 & 81.04 & 0.40 \\
\hline- & - & (T) C2An.1r (Kaena) & 3.032 & - & - & $89.95 ?$ & - & - & - & - & - \\
\hline- & - & (B) C2An.1r (Kaena) & 3.116 & - & - & $92.5 ?$ & - & - & - & - & - \\
\hline $11 \mathrm{H}-3, \sim 50$ & $11 \mathrm{H}-3, \sim 80$ & (T) C2An.2r (Mammoth) & 3.207 & 95.20 & 95.50 & 95.35 & 0.15 & 101.73 & 102.03 & 101.88 & 0.15 \\
\hline $11 \mathrm{H}-4, \sim 30$ & $11 \mathrm{H}-4, \sim 50$ & (B) C2An.2r (Mammoth) & 3.33 & 96.50 & 96.70 & 96.60 & 0.10 & 103.03 & 103.23 & 103.13 & 0.10 \\
\hline $12 \mathrm{H}-6, \sim 40$ & $12 \mathrm{H}-6, \sim 60$ & (T) C2Ar (Gauss/Gilbert) & 3.596 & 109.75 & 109.95 & 109.85 & 0.10 & 115.80 & 116.00 & 115.90 & 0.10 \\
\hline- & - & (T) C3n.1n (Cochiti) & 4.187 & - & - & - & - & - & - & - & - \\
\hline $15 \mathrm{H}-2, \sim 55$ & $15 \mathrm{H}-2, \sim 65$ & (B) C3n.1n (Cochiti) & 4.3 & 132.35 & 133.45 & 132.90 & 0.55 & 136.59 & 137.69 & 137.14 & 0.55 \\
\hline $16 \mathrm{H}-2, \sim 0$ & $16 \mathrm{H}-2, \sim 60$ & (T) C 3n.2n (Nunivak) & 4.493 & 141.30 & 141.90 & 141.60 & 0.30 & 141.30 & 141.90 & 141.60 & 0.30 \\
\hline $16 \mathrm{H}-4, \sim 85$ & $16 \mathrm{H}-5, \sim 40$ & (B) C $3 n \cdot 2 n$ (Nunivak) & 4.631 & 145.10 & 146.10 & 145.60 & 0.50 & 145.10 & 146.10 & 145.60 & 0.50 \\
\hline $16 \mathrm{H}-7, \sim 45$ & $17 \mathrm{H}-2, \sim 5$ & (T) C 3n.3n (Sidufjall) & 4.799 & 149.15 & 150.85 & 150.00 & 0.85 & 149.15 & 159.73 & 150.00 & 0.85 \\
\hline $17 \mathrm{H}-4, \sim 135$ & $17 \mathrm{H}-5, \sim 5$ & (B) C3n.3n (Sidufjall) & 4.896 & 155.17 & 155.37 & 155.27 & 0.10 & 164.05 & 164.25 & 164.15 & 0.10 \\
\hline $17 \mathrm{H}-5, \sim 110$ & $17 \mathrm{H}-5, \sim 130$ & (T) C3n.4n (Thvera) & 4.997 & 156.40 & 156.60 & 156.50 & 0.10 & 165.28 & 165.48 & 165.38 & 0.10 \\
\hline 346-U1424B- & 346-U1424B- & & & & & & & & & & \\
\hline $4 \mathrm{H}-2, \sim 30$ & $4 \mathrm{H}-3, \sim 80$ & (B) C1n (Brunhes/Matuyama) & 0.781 & 23.50 & 25.50 & 24.50 & 1.00 & 26.72 & 28.72 & 27.72 & 1.00 \\
\hline $4 \mathrm{H}-6, \sim 70$ & $4 \mathrm{H}-7, \sim 75$ & (T) C1r.1n (Jaramillo) & 0.988 & 29.90 & 30.90 & 30.40 & 0.50 & 33.12 & 34.12 & 33.62 & 0.50 \\
\hline $5 \mathrm{H}-3, \sim 145$ & $5 \mathrm{H}-4, \sim 75$ & (B) C1r.1n (Jaramillo) & 1.072 & 35.10 & 35.90 & 35.50 & 0.40 & 38.51 & 39.31 & 38.91 & 0.40 \\
\hline $6 \mathrm{H}-1, \sim 0$ & $6 \mathrm{H}-1, \sim 20$ & (T) C1r.2n (Cobb Mountain) & 1.173 & 40.70 & 40.90 & 40.80 & 0.10 & 45.07 & 45.27 & 45.17 & 0.10 \\
\hline $6 \mathrm{H}-1, \sim 90$ & $6 \mathrm{H}-2, \sim 13$ & (B) C1r.2n (Cobb Mountain) & 1.185 & 41.60 & 42.20 & 41.90 & 0.30 & 45.97 & 46.57 & 46.27 & 0.30 \\
\hline $7 \mathrm{H}-3, \sim 95$ & $7 \mathrm{H}-4, \sim 5$ & (T) C2n (Olduvai) & 1.778 & 54.15 & 54.75 & 54.45 & 0.30 & 59.38 & 59.98 & 59.68 & 0.30 \\
\hline $7 \mathrm{H}-6, \sim 75$ & $7 \mathrm{H}-6, \sim 115$ & (B) C2n (Olduvai) & 1.945 & 58.45 & 58.85 & 58.65 & 0.20 & 63.68 & 64.08 & 63.88 & 0.20 \\
\hline $8 \mathrm{H}-2, \sim 40$ & $8 \mathrm{H}-2, \sim 60$ & (T) C2r.1n (Reunion) & 2.128 & 61.60 & 61.80 & 61.70 & 0.10 & 67.66 & 67.86 & 67.76 & 0.10 \\
\hline $8 \mathrm{H}-2, \sim 120$ & $8 \mathrm{H}-2, \sim 140$ & (B) C2r.1n (Reunion) & 2.148 & 62.40 & 62.60 & 62.50 & 0.10 & 68.46 & 68.66 & 68.56 & 0.10 \\
\hline $9 \mathrm{H}-4, \sim 75$ & $9 \mathrm{H}-4, \sim 135$ & (T) C2An.1n (Matuyama/Gauss) & 2.581 & 74.40 & 75.00 & 74.70 & 0.30 & 81.04 & 81.64 & 81.34 & 0.30 \\
\hline $10 \mathrm{H}-6, \sim 80$ & $10 \mathrm{H}-7, \sim 30$ & (T) C2An.1r (Kaena) & 3.032 & 87.00 & 88.00 & 87.50 & 0.50 & 93.82 & 94.82 & 94.32 & 0.50 \\
\hline $11 \mathrm{H}-2, \sim 75$ & $11 \mathrm{H}-3, \sim 25$ & (B) C2An.1r (Kaena) & 3.116 & 90.45 & 91.45 & 90.95 & 0.50 & 98.09 & 99.09 & 98.59 & 0.50 \\
\hline $11 \mathrm{H}-4, \sim 120$ & $11 \mathrm{H}-5, \sim 110$ & (T) C2An.2r (Mammoth) & 3.207 & 93.90 & 95.30 & 94.60 & 0.70 & 101.54 & 102.94 & 102.24 & 0.70 \\
\hline $11 \mathrm{H}-7, \sim 50$ & $12 \mathrm{H}-1, \sim 110$ & (B) C2An.2r (Mammoth) & 3.33 & 97.60 & 98.80 & 98.20 & 0.60 & 105.24 & 106.36 & 105.76 & 0.60 \\
\hline $13 \mathrm{H}-2, \sim 0$ & $13 \mathrm{H}-2, \sim 60$ & (T) C2Ar (Gauss/Gilbert) & 3.596 & 107.40 & 108.00 & 107.70 & 0.30 & 115.53 & 116.13 & 115.83 & 0.30 \\
\hline $15 \mathrm{H}-4, \sim 110$ & $15 \mathrm{H}-6, \sim 110$ & (T) C3n.1n (Cochiti) & 4.187 & 131.80 & 134.80 & 133.30 & 1.50 & 141.37 & 144.37 & 142.87 & 1.50 \\
\hline- & - & (B) C3n.1n (Cochiti) & 4.3 & - & - & $136.6 ?$ & - & - & - & - & - \\
\hline $16 \mathrm{H}-5, \sim 15$ & $16 \mathrm{H}-5, \sim 85$ & (T) C3n.2n (Nunivak) & 4.493 & 141.85 & 142.55 & 142.20 & 0.35 & 148.80 & 149.50 & 149.15 & 0.35 \\
\hline $17 \mathrm{H}-2, \sim 35$ & $17 \mathrm{H}-2, \sim 65$ & (B) C $3 n \cdot 2 n$ (Nunivak) & 4.631 & 147.05 & 147.35 & 147.20 & 0.15 & 154.64 & 154.94 & 162.53 & 0.15 \\
\hline $17 \mathrm{H}-4, \sim 40$ & $17 \mathrm{H}-4, \sim 100$ & (T) C3n.3n (Sidufjall) & 4.799 & 151.10 & 151.70 & 151.40 & 0.30 & 158.69 & 159.29 & 158.99 & 0.30 \\
\hline 346-U1424C- & 346-U1424C- & & & & & & & & & & \\
\hline- & - & (B) C1n (Brunhes/Matuyama) & 0.781 & - & - & - & - & - & - & - & - \\
\hline $4 \mathrm{H}-4, \sim 100$ & $4 \mathrm{H}-4, \sim 140$ & (T) C1r.1n (Jaramillo) & 0.988 & 31.40 & 31.80 & 31.60 & 0.20 & 34.73 & 35.13 & 34.93 & 0.20 \\
\hline $5 \mathrm{H}-1, \sim 140$ & $5 \mathrm{H}-2, \sim 70$ & (B) C1r.1n (Jaramillo) & 1.072 & 36.80 & 37.60 & 37.20 & 0.40 & 40.85 & 41.65 & 41.25 & 0.40 \\
\hline $5 \mathrm{H}-5, \sim 30$ & $5 \mathrm{H}-5, \sim 50$ & (T) C1r.2n (Cobb Mountain) & 1.173 & 41.70 & 41.90 & 41.80 & 0.10 & 45.75 & 45.95 & 45.85 & 0.10 \\
\hline $5 \mathrm{H}-5, \sim 80$ & $5 \mathrm{H}-5, \sim 100$ & (B) C1r.2n (Cobb Mountain) & 1.185 & 42.20 & 42.40 & 42.30 & 0.10 & 46.25 & 46.45 & 46.35 & 0.10 \\
\hline
\end{tabular}


Table T16 (continued).

\begin{tabular}{|c|c|c|c|c|c|c|c|c|c|c|c|}
\hline \multicolumn{2}{|c|}{ Core, section, interval $(\mathrm{cm})$} & \multirow[b]{2}{*}{ Polarity boundaries } & \multirow{2}{*}{$\begin{array}{c}\text { Age } \\
\text { (Ma) }\end{array}$} & \multicolumn{4}{|c|}{ Depth CSF-A (m) } & \multicolumn{4}{|c|}{ Depth CCSF (m) } \\
\hline Top & Bottom & & & Top & Bottom & Midpoint & \pm & Top & Bottom & Midpoint & \pm \\
\hline $6 \mathrm{H}-7, \sim 45$ & $7 \mathrm{H}-1, \sim 35$ & (T) C2n (Olduvai) & 1.778 & 54.15 & 54.75 & 54.45 & 0.30 & 59.45 & 60.05 & 59.75 & 0.30 \\
\hline $7 \mathrm{H}-4, \sim 60$ & 7H-5, 100 & (B) $\mathrm{C} 2 \mathrm{n}$ (Olduvai) & 1.945 & 60.00 & 61.40 & 60.70 & 0.70 & 65.30 & 66.70 & 66.00 & 0.70 \\
\hline $7 \mathrm{H}-6, \sim 60$ & 7H-6, 100 & (T) C2r.1n (Reunion) & 2.128 & 62.50 & 62.90 & 62.70 & 0.20 & 67.80 & 68.20 & 68.00 & 0.20 \\
\hline $7 \mathrm{H}-6, \sim 130$ & - & (B) C2r.1n (Reunion) & 2.148 & 63.20 & 64.00 & 63.60 & 0.40 & 68.50 & 69.30 & 68.90 & 0.40 \\
\hline
\end{tabular}

Bold $=$ boundaries that are relatively well defined. $B=$ Bottom, $T=$ top.

Table T17. Vertical offsets applied to cores in order to align a specific feature in adjacent cores, Site U1424.

\begin{tabular}{|c|c|c|c|c|c|c|c|c|c|c|c|c|c|c|c|c|c|}
\hline Core & $\begin{array}{l}\text { Vertical } \\
\text { offset } \\
\text { (m) }\end{array}$ & $\begin{array}{c}\text { Top } \\
\text { depth } \\
\text { CSF-A (m) }\end{array}$ & $\begin{array}{l}\text { Bottom } \\
\text { depth } \\
\text { CSF-A (m) }\end{array}$ & $\begin{array}{c}\text { Top } \\
\text { depth } \\
\text { CCSF-A (m) }\end{array}$ & $\begin{array}{l}\text { Curated } \\
\text { bottom } \\
\text { depth } \\
\text { CCSF-A (m) }\end{array}$ & Core & $\begin{array}{l}\text { Vertical } \\
\text { offset } \\
(\mathrm{m})\end{array}$ & $\begin{array}{c}\text { Top } \\
\text { depth } \\
\text { CSF-A (m) }\end{array}$ & $\begin{array}{l}\text { Bottom } \\
\text { depth } \\
\text { CSF-A (m) }\end{array}$ & $\begin{array}{c}\text { Top } \\
\text { depth } \\
\text { CCSF-A (m) }\end{array}$ & $\begin{array}{l}\text { Curated } \\
\text { bottom } \\
\text { depth } \\
\text { CCSF-A (m) }\end{array}$ & Core & $\begin{array}{l}\text { Vertical } \\
\text { offset } \\
(\mathrm{m})\end{array}$ & $\begin{array}{c}\text { Top } \\
\text { depth } \\
\text { CSF-A (m) }\end{array}$ & $\begin{array}{l}\text { Bottom } \\
\text { depth } \\
\text { CSF-A (m) }\end{array}$ & $\begin{array}{c}\text { Top } \\
\text { depth } \\
\text { CCSF-A (m) }\end{array}$ & $\begin{array}{c}\text { Curated } \\
\text { bottom } \\
\text { depth } \\
\text { CCSF-A (m) }\end{array}$ \\
\hline 346-U1424A- & & & & & & 346-U1424 & & & & & & $346-U 142$ & & & & & \\
\hline $1 \mathrm{H}$ & 0.00 & 0.0 & 6.8 & 0.00 & 6.80 & $1 \mathrm{H}$ & -0.03 & 0 & 2.7 & -0.03 & 2.64 & & & & & & \\
\hline $2 \mathrm{H}$ & 0.77 & 6.8 & 16.3 & 7.57 & 17.22 & $2 \mathrm{H}$ & 2.15 & 2.7 & 12.2 & 4.85 & 14.12 & & & & & & \\
\hline $3 \mathrm{H}$ & 1.90 & 16.3 & 25.8 & 18.20 & 27.18 & $3 \mathrm{H}$ & 2.46 & 12.2 & 21.7 & 14.66 & 22.65 & & & & & & \\
\hline $4 \mathrm{H}$ & 3.30 & 25.8 & 35.3 & 29.10 & 38.78 & $4 \mathrm{H}$ & 3.22 & 21.7 & 31.2 & 24.92 & 34.15 & $4 \mathrm{H}$ & 3.33 & 25.9 & 35.4 & 29.2 & 38.61 \\
\hline $5 \mathrm{H}$ & 4.00 & 35.3 & 44.8 & 39.30 & 48.92 & $5 \mathrm{H}$ & 3.40 & 31.2 & 40.7 & 34.60 & 44.25 & $5 \mathrm{H}$ & 4.05 & 35.4 & 44.9 & 39.4 & 48.78 \\
\hline $6 \mathrm{H}$ & 4.57 & 44.8 & 54.3 & 49.37 & 58.96 & $6 \mathrm{H}$ & 4.37 & 40.7 & 50.2 & 45.07 & 54.63 & $6 \mathrm{H}$ & 4.10 & 44.9 & 54.4 & 49.0 & 58.59 \\
\hline $7 \mathrm{H}$ & 5.13 & 54.3 & 63.8 & 59.43 & 69.15 & $7 \mathrm{H}$ & 5.23 & 50.2 & 59.7 & 55.43 & 65.08 & $7 \mathrm{H}$ & 5.30 & 54.4 & 63.9 & 59.7 & 69.32 \\
\hline $8 \mathrm{H}$ & 4.62 & 63.8 & 73.3 & 68.42 & 77.84 & $8 \mathrm{H}$ & 6.06 & 59.7 & 69.2 & 65.76 & 75.04 & & & & & & \\
\hline $9 \mathrm{H}$ & 5.34 & 73.3 & 82.8 & 78.64 & 88.37 & $9 \mathrm{H}$ & 6.64 & 69.2 & 78.7 & 75.84 & 85.55 & & & & & & \\
\hline $10 \mathrm{H}$ & 5.86 & 82.8 & 92.3 & 88.66 & 98.28 & $10 \mathrm{H}$ & 6.82 & 78.7 & 88.2 & 85.52 & 95.22 & & & & & & \\
\hline $11 \mathrm{H}$ & 6.53 & 92.3 & 101.8 & 98.83 & 108.40 & $11 \mathrm{H}$ & 7.64 & 88.2 & 97.7 & 95.84 & 105.50 & & & & & & \\
\hline $12 \mathrm{H}$ & 6.05 & 101.8 & 111.3 & 107.85 & 117.58 & $12 \mathrm{H}$ & 7.56 & 97.7 & 107.2 & 105.26 & 115.07 & & & & & & \\
\hline $13 \mathrm{H}$ & 6.78 & 111.3 & 120.8 & 118.08 & 127.90 & $13 \mathrm{H}$ & 8.13 & 107.2 & 116.7 & 115.33 & 125.15 & & & & & & \\
\hline $14 \mathrm{H}$ & 7.33 & 120.8 & 130.3 & 128.13 & 137.88 & $14 \mathrm{H}$ & 9.14 & 116.7 & 126.2 & 125.84 & 135.68 & & & & & & \\
\hline $15 \mathrm{H}$ & 4.24 & 130.3 & 139.8 & 134.54 & 144.44 & $15 \mathrm{H}$ & 9.57 & 126.2 & 135.7 & 135.77 & 145.51 & & & & & & \\
\hline $16 \mathrm{H}$ & 8.16 & 139.8 & 149.3 & 147.96 & 157.80 & $16 \mathrm{H}$ & 6.95 & 135.7 & 145.2 & 142.65 & 152.53 & & & & & & \\
\hline $17 \mathrm{H}$ & 8.88 & 149.3 & 158.8 & 158.18 & 167.75 & $17 \mathrm{H}$ & 7.59 & 145.2 & 154.7 & 152.79 & 162.67 & & & & & & \\
\hline
\end{tabular}


Table T18. Splice intervals, Site U1424.

\begin{tabular}{|c|c|c|c|c|c|c|c|c|}
\hline Hole, core, section & $\begin{array}{c}\text { Depth in } \\
\text { section }(\mathrm{cm})\end{array}$ & $\begin{array}{c}\text { Depth } \\
\text { CSF-A (m) }\end{array}$ & $\begin{array}{c}\text { Depth } \\
\text { CCSF-D (m) }\end{array}$ & Hole, core, section & $\begin{array}{c}\text { Depth in } \\
\text { section }(\mathrm{cm})\end{array}$ & $\begin{array}{c}\text { Depth } \\
\text { CSF-A (m) }\end{array}$ & $\begin{array}{c}\text { Depth } \\
\text { CCSF-D (m) }\end{array}$ & $\begin{array}{c}\text { Data used } \\
\text { to tie }\end{array}$ \\
\hline $346-$ & & & & 346- & & & & \\
\hline U1424A-1H-1 & 0 & 0.00 & 0.00 & U1424A-1H-4 & 116 & 5.66 & 5.66 & \\
\hline U1424B-2H-1 & 81 & 3.51 & 5.66 & U1424B-2H-6 & 57 & 10.78 & 12.93 & Blue \\
\hline U1424A-2H-4 & 86 & 12.16 & 12.93 & U1424A-2H-6 & 26 & 14.56 & 15.33 & Blue \\
\hline U1424B-3H-1 & 66 & 12.86 & 15.33 & U1424B-3H-4 & 60 & 17.30 & 19.77 & Blue \\
\hline U1424A-3H-2 & 7 & 17.87 & 19.77 & U1424A-3H-5 & 148 & 23.78 & 25.68 & Blue \\
\hline U1424B-4H-1 & 76 & 22.46 & 25.68 & U1424B-4H-4 & 142 & 27.62 & 30.84 & Blue \\
\hline U1424A-4H-2 & 24 & 27.54 & 30.84 & U1424A-4H-7 & 23 & 34.73 & 38.03 & Blue \\
\hline U1424B-5H-3 & 97 & 34.63 & 38.03 & U1424B-5H-5 & 81 & 37.47 & 40.88 & Blue \\
\hline U1424A-5H-2 & 8 & 36.88 & 40.88 & U1424A-5H-5 & 44 & 41.74 & 45.74 & Blue \\
\hline U1424B-6H-1 & 67 & 41.37 & 45.74 & U1424B-6H-6 & 50 & 48.57 & 52.94 & Blue \\
\hline U1424A-6H-3 & 57 & 48.37 & 52.94 & U1424A-6H-5 & 139 & 52.19 & 56.76 & Blue \\
\hline U1424B-7H-1 & 133 & 51.53 & 56.76 & U1424B-7H-6 & 109 & 58.79 & 64.03 & Blue \\
\hline U1424A-7H-4 & 9 & 58.89 & 64.03 & U1424A-7H-6 & 144 & 63.24 & 68.37 & Blue \\
\hline U1424B-8H-2 & 111 & 62.31 & 68.37 & U1424B-8H-5 & 97 & 66.67 & 72.74 & Blue \\
\hline U1424A-8H-3 & 132 & 68.12 & 72.74 & U1424A-8H-6 & 119 & 72.49 & 77.10 & MS \\
\hline U1424B-9H-1 & 126 & 70.46 & 77.10 & U1424B-9H-6 & 134 & 78.00 & 84.65 & MS \\
\hline U1424A-9H-4 & 150 & 79.30 & 84.65 & U1424A-9H-7 & 4 & 82.04 & 87.38 & MS \\
\hline U1424B-10H-2 & 36 & 80.56 & 87.38 & U1424B-10H-6 & 48 & 86.68 & 93.50 & Blue \\
\hline U1424A-10H-4 & 34 & 87.64 & 93.50 & U1424A-10H-6 & 117 & 91.47 & 97.33 & Blue \\
\hline U1424B-11H-1 & 148 & 89.68 & 97.33 & U1424B-11H-5 & 26 & 94.46 & 102.10 & MS \\
\hline U1424A-11H-3 & 90 & 95.58 & 102.10 & U1424A-11H-6 & 77 & 99.95 & 106.47 & MS \\
\hline U1424B-12H-1 & 121 & 98.91 & 106.47 & U1424B-12H-6 & 103 & 106.23 & 113.79 & Blue \\
\hline U1424A-12H-4 & 141 & 107.74 & 113.79 & U1424A-12H-6 & 124 & 110.60 & 116.65 & Blue \\
\hline U1424B-13H-2 & 109 & 108.52 & 116.65 & U1424B-13H-4 & 2 & 111.95 & 120.08 & Blue \\
\hline U1424A-13H-2 & 51 & 113.31 & 120.08 & U1424A-13H-6 & 147 & 120.10 & 126.88 & Blue \\
\hline U1424B-14H-1 & 104 & 117.74 & 126.88 & U1424B-14H-4 & 80 & 122.00 & 131.14 & MS \\
\hline U1424A-14H-3 & 1 & 123.81 & 131.14 & U1424A-14H-6 & 121 & 129.41 & 136.74 & MS \\
\hline U1424B-15H-1 & 97 & 127.17 & 136.74 & U1424B-15H-4 & 129 & 131.99 & 141.56 & MS \\
\hline U1424A-15H-5 & 102 & 137.32 & 141.56 & U1424A-15H-6 & 108 & 138.88 & 143.13 & Litho, MS \\
\hline U1424B-16H-1 & 47 & 136.17 & 143.13 & U1424B-16H-5 & 45 & 142.15 & 149.10 & Litho \\
\hline U1424A-16H-1 & 114 & 140.94 & 149.10 & U1424A-16H-6 & 2 & 147.24 & 155.40 & Litho, MS \\
\hline U1424B-17H-2 & 111 & 147.81 & 155.40 & U1424B-17H-6 & 17 & 152.87 & 160.46 & MS \\
\hline U1424A-17H-2 & 78 & 151.58 & 160.46 & U1424A-17H-CC & 13 & 158.87 & 167.75 & MS \\
\hline
\end{tabular}

MS = magnetic susceptibility, Litho = lithostratigraphic feature, Blue = RGB blue datum. 
Table T19. Constrained tie points for depth-age relationship, Site U1424.

\begin{tabular}{|c|c|c|c|c|c|c|c|}
\hline $\begin{array}{l}\text { Selected ties for } \\
\text { depth-age lines }\end{array}$ & $\begin{array}{l}\text { Event } \\
\text { type }\end{array}$ & Bioevents and epoch boundaries & $\begin{array}{c}\text { Depth } \\
\text { CCSF-A (m) }\end{array}$ & $\begin{array}{l}\text { Depth range } \\
\qquad( \pm)\end{array}$ & $\begin{array}{l}\text { Age } \\
(\mathrm{Ma})\end{array}$ & $\begin{array}{l}\text { Age range } \\
\quad( \pm)\end{array}$ & $\begin{array}{c}\text { Sedimentation } \\
\text { rate } \\
(\mathrm{m} / \mathrm{m} . \mathrm{y} .)\end{array}$ \\
\hline \multirow[t]{5}{*}{ Core top } & & & 0.00 & & 0.000 & & \\
\hline & $\mathrm{R}$ & LO Lychnocanoma sakaii & 3.38 & 3.38 & 0.050 & 0.000 & 34.8 \\
\hline & $\mathrm{R}$ & LO Spongodiscus sp. & 11.96 & 5.21 & 0.290 & 0.000 & \\
\hline & PM & Bottom of C1n (Brunhes/Matuyama) & 27.21 & 0.51 & 0.781 & 0.000 & \\
\hline & PF & LO Neogloboquadrina kagaensis & 31.57 & 0.38 & 0.700 & 0.000 & \\
\hline \multirow[t]{6}{*}{ Paleomag } & PM & Top of C1r.1n (Jaramillo) & 34.38 & 0.55 & 0.988 & 0.000 & \\
\hline & PM & Bottom of C1r.1n (Jaramillo) & 40.25 & 1.00 & 1.072 & 0.000 & 57.2 \\
\hline & $\mathrm{R}$ & LO Eucyrtidium matuyamai & 43.80 & 5.07 & 1.030 & 0.000 & \\
\hline & $\mathrm{R}$ & LO Axoprunum acquilonium & 43.80 & 5.07 & 1.450 & 0.250 & \\
\hline & PM & Top of C1r.2n (Cobb Mountain) & 45.51 & 0.34 & 1.173 & 0.000 & \\
\hline & PM & Bottom of $\mathrm{C} 1 \mathrm{r} \cdot 2 \mathrm{n}$ (Cobb Mountain) & 46.34 & 0.06 & 1.185 & 0.000 & \\
\hline \multirow[t]{5}{*}{ Unit $I A / I B$} & & & 46.91 & & 1.207 & & \\
\hline & $\mathrm{R}$ & FO Eucyrtidium matuyamai & 53.89 & 5.02 & 1.980 & 0.000 & 23.3 \\
\hline & PM & Top of C $2 n$ (Olduvai) & 59.62 & 0.13 & 1.778 & 0.000 & \\
\hline & PM & Bottom of C $2 n$ (Olduvai) & 64.27 & 0.73 & 1.945 & 0.000 & \\
\hline & PM & Top of C2r.1n (Reunion) & 67.83 & 0.17 & 2.128 & 0.000 & \\
\hline \multirow[t]{6}{*}{ Unit IB/IIA } & & & 68.62 & & 2.139 & & \\
\hline & PM & Bottom of C2r.1n (Reunion) & 68.73 & 0.17 & 2.148 & 0.000 & 29.0 \\
\hline & PM & Top of C2An.1n (Matuyama/Gauss) & 81.19 & 0.15 & 2.581 & 0.000 & \\
\hline & D & LO Neodenticula kamtschatica & 83.06 & 5.27 & 2.650 & 0.050 & \\
\hline & $\mathrm{R}$ & FO Cycladophora davisiana & 83.06 & 5.27 & 2.700 & 0.000 & \\
\hline & $\mathrm{R}$ & LO Hexacontium parviakitaensis & 83.06 & 5.27 & 2.700 & 0.000 & \\
\hline \multirow[t]{5}{*}{ Unit IIA/IIB } & & & 84.55 & & 2.689 & & \\
\hline & PM & Top of C2An.1r (Kaena) & 95.07 & 0.75 & 3.032 & 0.000 & 34.5 \\
\hline & PM & Bottom of C2An.1r (Kaena) & 98.81 & 0.22 & 3.116 & 0.000 & \\
\hline & PM & Top of C2An.2r (Mammoth) & 101.64 & 0.61 & 3.207 & 0.000 & \\
\hline & PM & Bottom of C1An.2r (Mammoth) & 105.15 & 0.61 & 3.330 & 0.000 & \\
\hline \multirow[t]{3}{*}{ Paleomag } & PM & Top of C2Ar (Gauss/Gilbert) & 115.87 & 0.03 & 3.596 & 0.000 & \\
\hline & $\mathrm{R}$ & FO Hexacontium parviakitaensis & 122.69 & 5.16 & 3.900 & 0.000 & 72.3 \\
\hline & $\mathrm{R}$ & RD Siphocampe arachnea group & 132.84 & 4.99 & 4.600 & 0.000 & \\
\hline \multirow[t]{5}{*}{ Biostrat } & & & 137.83 & & 3.900 & & \\
\hline & PM & Bottom of C3n.1n (Cochiti) & 140.35 & 3.20 & 4.300 & 0.000 & 14.3 \\
\hline & $\mathrm{D}$ & FO Neodenticula koizumii & 141.11 & 3.28 & 3.650 & 0.250 & \\
\hline & $\mathrm{T}$ & Znp-Ohta & 142.86 & 0.05 & 3.900 & 0.000 & \\
\hline & PM & Top of C3n.1n (Cochiti) & 142.87 & 0.00 & 4.187 & 0.000 & \\
\hline \multirow[t]{8}{*}{ Paleomag } & & & 143.55 & & 4.300 & & \\
\hline & PM & Top of C $3 n .2 n$ (Nunivak) & 149.46 & 0.31 & 4.493 & 0.000 & 29.6 \\
\hline & $\mathrm{R}$ & RI Siphocampe arachnea group & 151.07 & 6.68 & 4.700 & 0.000 & \\
\hline & PM & Bottom of C $3 n .2 n$ (Nunivak) & 154.64 & 0.16 & 4.631 & 0.000 & \\
\hline & PM & Top of C $3 n .3 n$ (Sidufjall) & 158.94 & 0.06 & 4.799 & 0.000 & \\
\hline & PM & Bottom of C $3 n .3 n$ (Sidufjall) & 162.28 & 0.00 & 4.896 & 0.000 & \\
\hline & PM & Top of C $3 n .4 n$ (Thvera) & 165.38 & 0.00 & 4.997 & 0.000 & \\
\hline & $\mathrm{R}$ & FO Larcopyle pylomaticus & 167.70 & 0.00 & 5.300 & 0.000 & \\
\hline Core bottom & & & 167.75 & & 5.118 & & \\
\hline
\end{tabular}

$\mathrm{R}=$ radiolarian, $\mathrm{PF}=$ planktonic foraminifer, $\mathrm{CN}=$ calcareous nannofossil, $\mathrm{D}=$ diatom, $\mathrm{PM}=$ paleomagnetism, $\mathrm{T}=$ tephra. $\mathrm{LO}=$ last occurrence, $\mathrm{FO}=$ first occurrence, $\mathrm{RI}=$ rapid increase, $\mathrm{RD}=$ rapid decrease. 